\author{
UNIVERSIDADE DE SÃO PAULO \\ ESCOLA DE ENGENHARIA DE SÃO CARLOS \\ DEPARTAMENTO DE HIDRÁULICA E SANEAMENTO
}

RAFAEL PEDROLLO DE PAES

\begin{abstract}
Análise da translação da onda de cheia efluente do reservatório da UHE Manso na bacia hidrográfica do rio Cuiabá, Mato Grosso
\end{abstract}

Orientação: Prof. Dr. João Luiz Boccia Brandão

São Carlos - SP 2011 



\section{Análise da translação da onda de cheia efluente do reservatório da UHE Manso na bacia hidrográfica do rio \\ Cuiabá, Mato Grosso}

Dissertação apresentada ao Programa de Pós-Graduação de Engenharia Hidráulica e Saneamento, da Escola de Engenharia de São Carlos, da Universidade de São Paulo como parte dos requisitos para a obtenção do título de Mestre em Ciências - Programa de Hidráulica e Saneamento.

Orientador: Prof. Dr. João Luiz Boccia Brandão

VERSÃO CORRIGIDA

São Carlos - SP

2011 
AUTORIZO A REPRODUÇÃO E DIVULGAÇÃO TOTAL OU PARCIAL DESTE TRABALHO, POR QUALQUER MEIO CONVENCIONAL OU ELETRÔNICO, PARA FINS DE ESTUDO E PESQUISA, DESDE QUE CITADA A FONTE.

Ficha catalográfica preparada pela Seção de Tratamento

da Informação do Serviço de Biblioteca - EESC/USP

Paes, Rafael Pedrollo de
P126a Análise da translação da onda de cheia efluente do reservatório da UHE Manso
na bacia hidrográfica do rio Cuiabá, Mato Grosso / Rafael Pedrollo de Paes; orientador João Luiz Boccia Brandão. -- São Carlos, 2011.

Dissertação (Mestrado - Programa de Pós-Graduação e Área de Concentração em Hidráulica e Saneamento) - Escola de Engenharia de São Carlos da Universidade de São Paulo, 2011.

1. Hidráulica fluvial. 2. Amortecimento de reservatório. 3. Modelo hidrodinâmico. 4. Inundação fluvial. 5. Análise da cheia. 6. Bacia hidrográfica do rio Cuiabá. I. Título. 


\section{FOLHA DE JULGAMENTO}

Candidato(a): Engenheiro RAFAEL PEDROLLO DE PAES.

Dissertação defendida e julgada em 05/05/2011 perante a Comissão Julgadora:

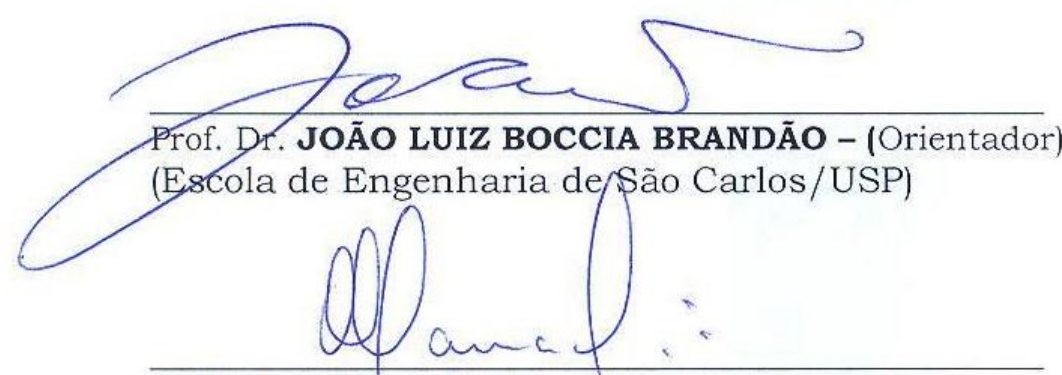

Prof. Dr. FREDERICO FABIO MAUAD

(Escola de Engenharia de São Carlos/USP)
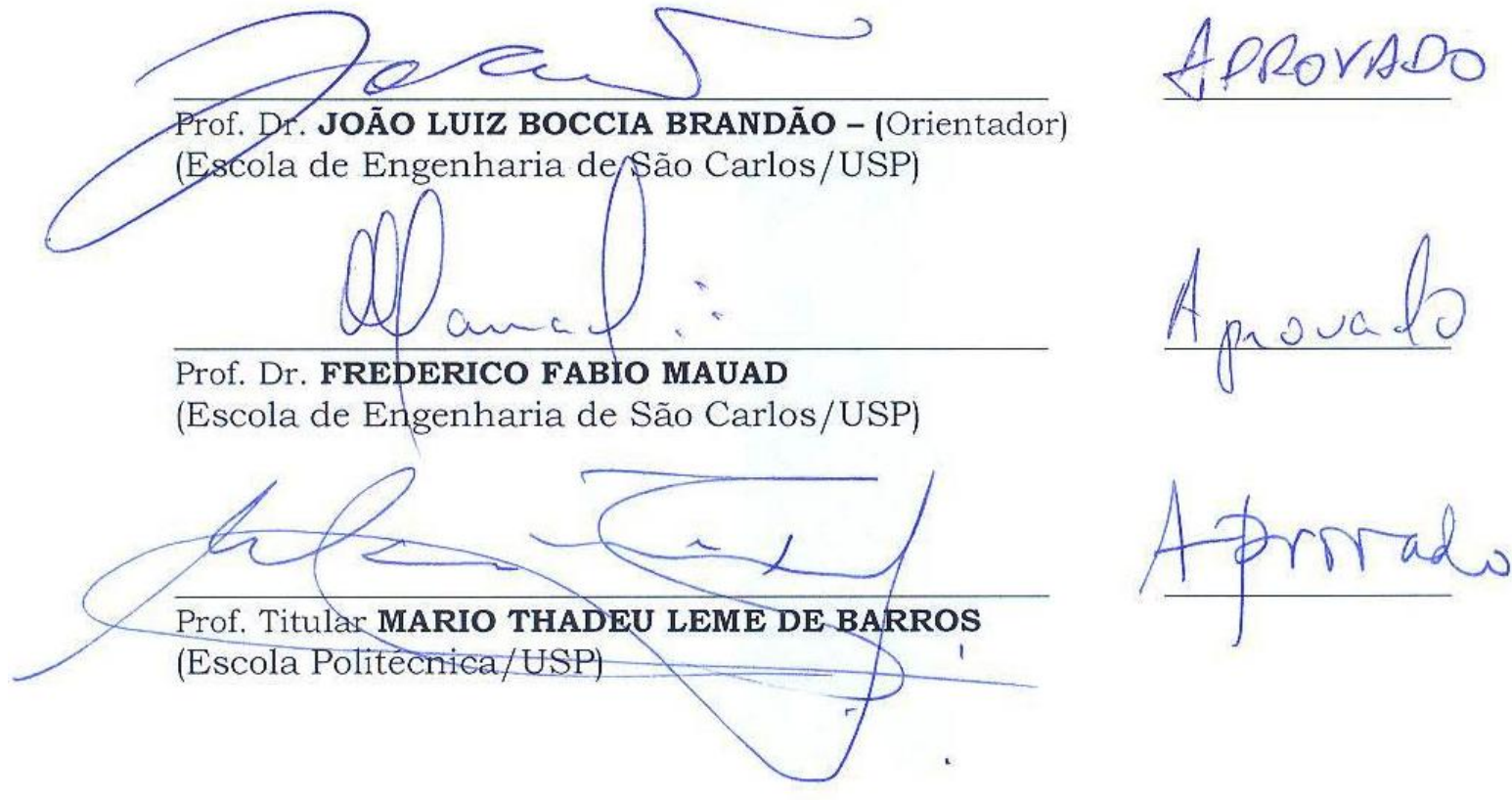

Prof. Titular MARIO THADEU LEME DE BARRO

(Escola Politecnica/USP)

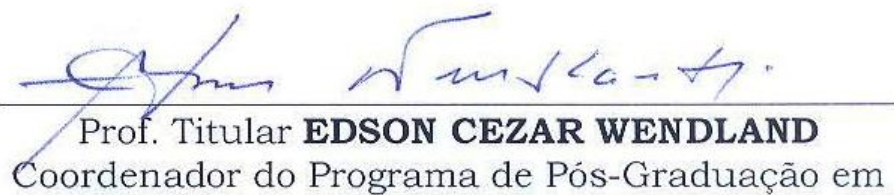

Coordenador do Programa de Pós-Graduação em

Engenharia Hielráulica e Saneamento.

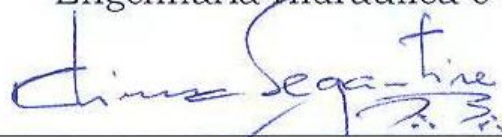

Prof. Associado PAULO CÉSAR LIMA SEGANTINE

Presidente da Comissã̉o da Pós-Graduação da EESC 


\section{DEDICATÓRIA}

Este trabalho é dedicado a duas pessoas: Amauri Silvério de Paes e Jandira Maria Pedrollo, que sem dúvida nenhuma fizeram o máximo pela educação de seus filhos, e honradamente têm colhido os frutos. Pai e mãe, muito obrigado! 


\section{AGRADECIMENTOS}

Presto minha gratidão aos parentes, aos amigos e à família que tanto ofereceu compreensão, apoio e auxílios : Jandira Maria Pedrollo, Amauri Silvério de Paes, Thais Pedrollo de Paes e Helton Alexandre de Jesus.

Meu orientador João Luis Boccia Brandão, que depositou confiança na minha pessoa e investiu em mim dois de seus anos nesta orientação (confesso que sua tranquilidade em muito me deu segurança em diversas situações).

Vários companheiros que colaboraram com o repasse de informações e material para esta pesquisa, entre eles Marcelo Roberto Rocha de Carvalho, Rafael Teodoro de Melo, Rubem Mauro de Palma Moura, Valmir José da Silva e Walter Corrêa Carvalho Junior; e ainda a equipe da Superintendência de Defesa Civil do Estado de Mato Grosso e da biblioteca da Secretaria de Estado de Meio Ambiente de Mato Grosso.

O pessoal que acompanhei com muito gosto durante as medições topobatimétricas: José Pedro Rocha, Belrmiro Martins, Bruno e Ivan; os quais me repassaram muito ensinamento prático.

As pessoas que coloboraram para a realização das topobatimetrias nos rios Manso e Cuiabá, em pareria entre a UFMT e a USP, por meio da PROCAD/CAPES, entre eles os professores Alexandre Silveira e Édson Cézar Wendland.

Ao professor José Rodolfo Scarati Martins, da EPUSP, pela oportunidade de trabalhar com o software CLiv durante o mestrado.

A CAPES, novamente, desta vez pela bolsa de pesquisa.

A Sá, Pavi, Rose, Marília, Valderez (Secretaria SHS/EESC/USP), André (Técnico em informática), funcionários da biblioteca EESC/USP e do Bandeijão, apelidado carinhosamente de Restaurante Universitário, que na minha opinião foram perfeitos nos serviços a que me relacionei.

Parceiros do LabSiN: Frederico Keizo Odan, Narumi Abe e Tais Arriero Shinma, pela companhia durante tantas horas de silêncio em frente ao computador, às vezes nem tanto, e pela amizade que sempre me ofereceram.

A professora Luisa Fernanda Ribeiro Reis pela possibilidade de trabalhar no LabSiN, bem como pelo constante apoio durante os dois anos de mestrado.

Integrantes república Curva de Rio: Anderson e David; assim como ex-integrantes e agregados: Átila, Bessa, Careta, César, Coxinha, Danilo, David, Fernando, Hermione, Prieto, Sprogou, Tazibi, Tchello, Vinícius, Xuxa... que, durante meu mestrado, faziam churrascos em carrinho de supermercado, companhia e bagunça; e discutiam música clássica, ciências exatas, literatura, dinheiro, filmes e, obviamente, as próprias discussões.

Pessoas, muitas das quais não conheço, responsáveis pelo que a USP e este programa de PósGraduação (Capes 7) é hoje, bem como os que possibilitaram o conhecimento técnico o qual me baseei para realizar este trabalho de dissertação.

O Prof. Domingos Iglésias Valério, cujo epíteto é "Senhor das Águas" (in memorian), quem tive orgulho de conhecer já durante este curso de pós-graduação, em 2009, e quem, por diversos motivos, deixou sua contribuição para a melhoria da sua e das gerações vindouras. 
A humildade é o princípio da sabedoria e a porta aberta para a feliz eternidade. Máxima de Domingos Iglésias Valério, mas que poderia ser, no mínimo, de qualquer aprendiz de sábio. 



\section{SUMÁRIO}

RESUMO

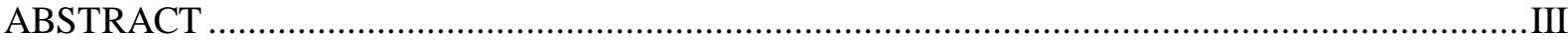

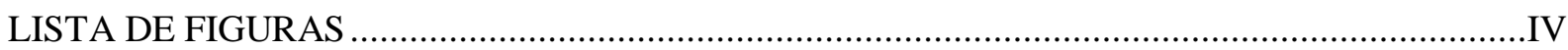

LISTA DE TABELAS E QUADRO .....................................................................................

LISTA DE SIGLAS E SÍMBOLOS MATEMÁTICOS …............................................................... VII

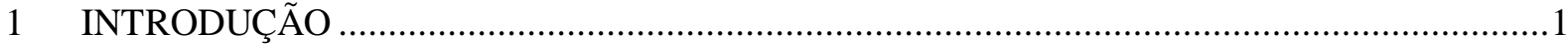

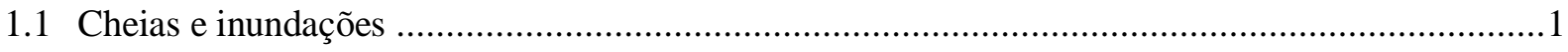

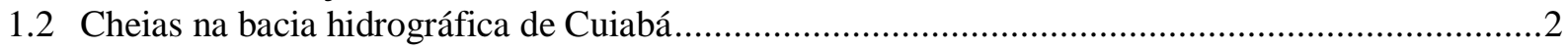

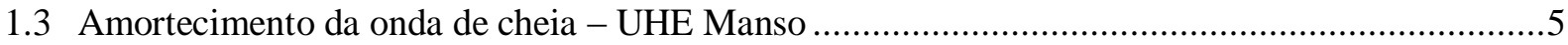

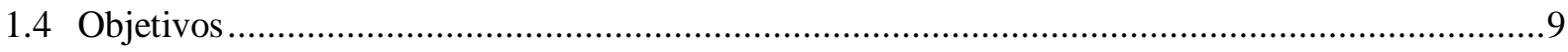

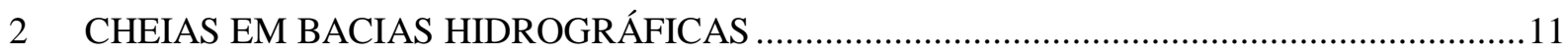

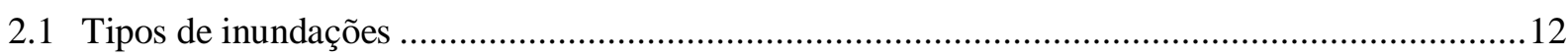

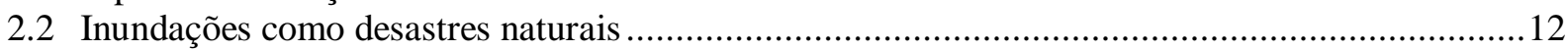

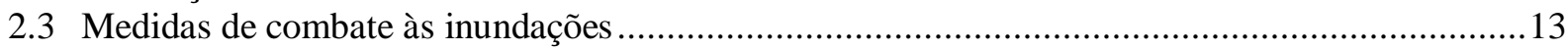

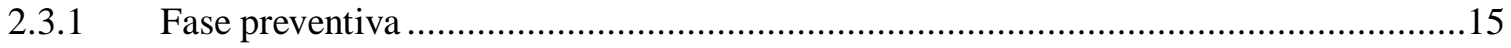

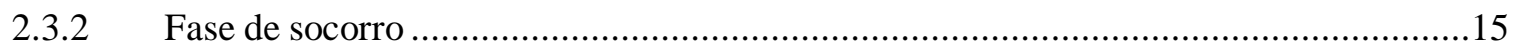

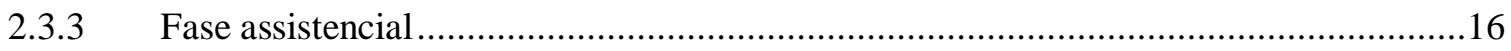

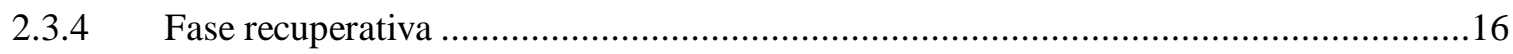

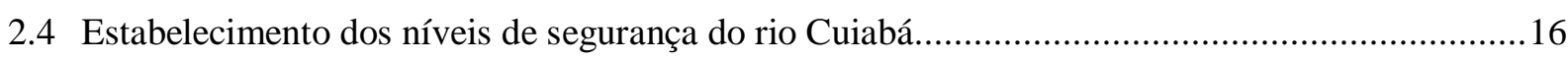

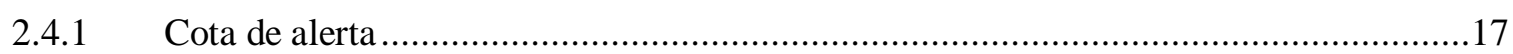

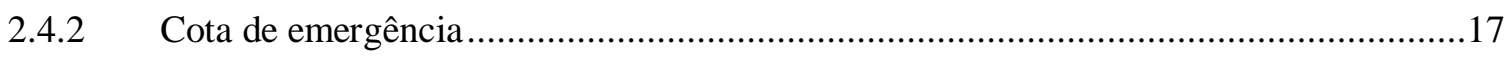

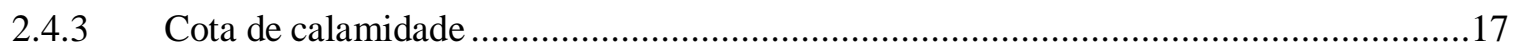

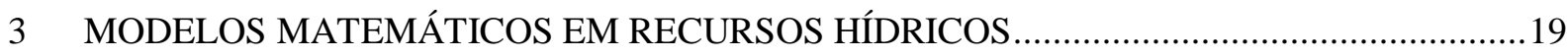

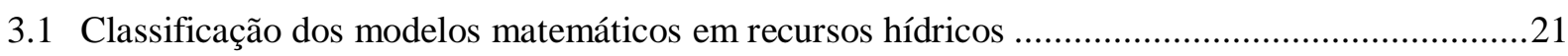

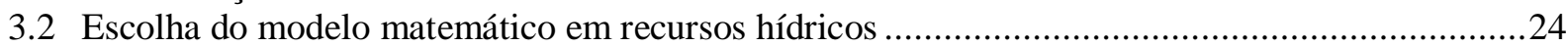

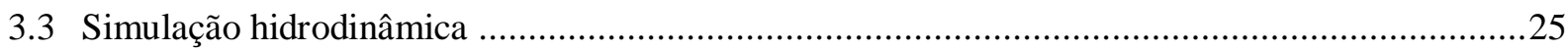

3.4 Métodos numéricos para os cálculos de escoamento hidrodinâmico ..........................................30

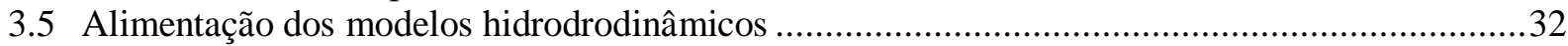

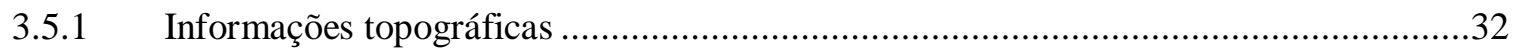

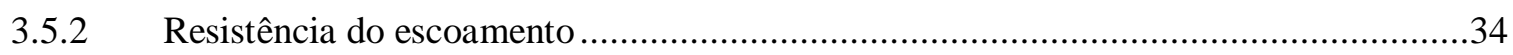

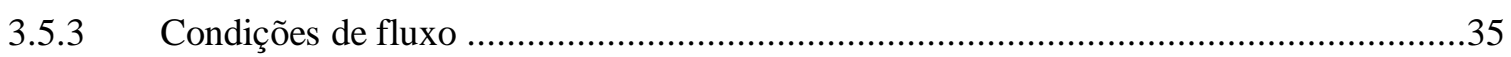

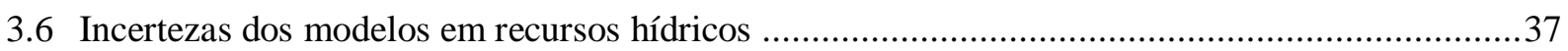

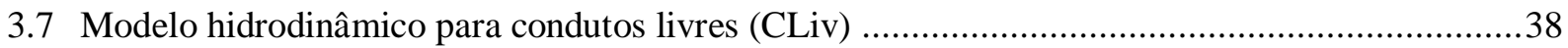

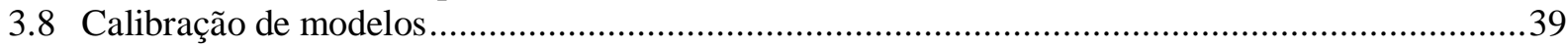

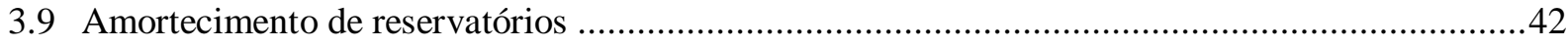

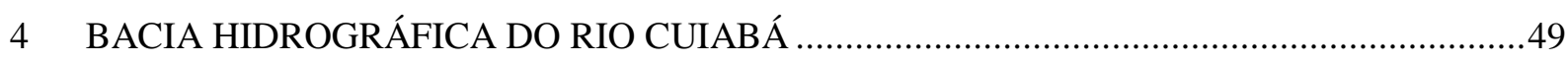

4.1 Considerações sobre as estações fluviométricas na BHC .........................................................55

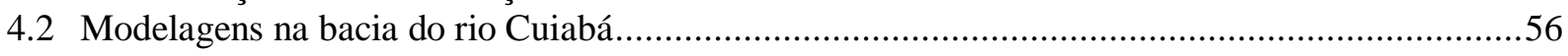

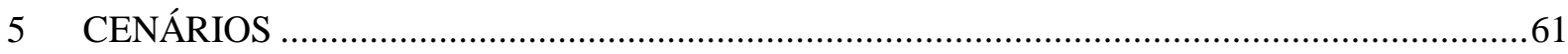

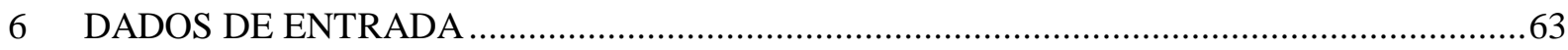

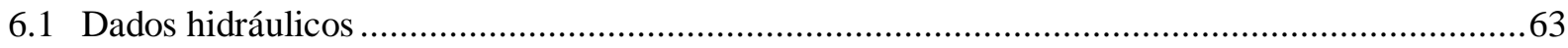

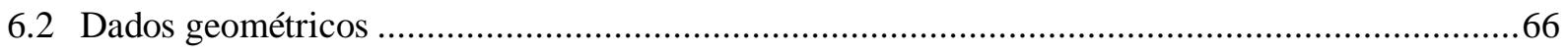




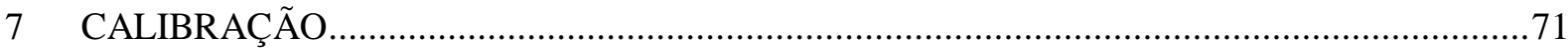

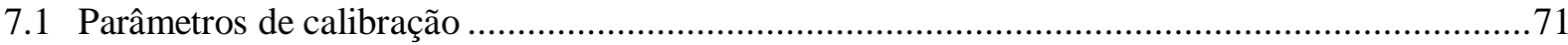

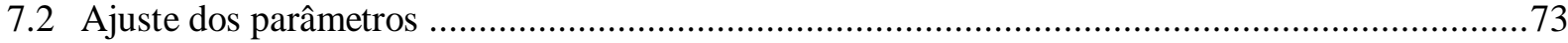

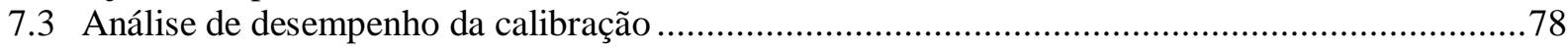

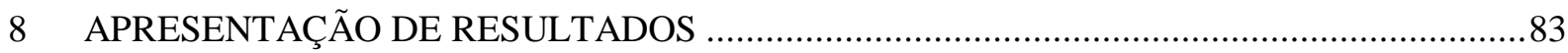

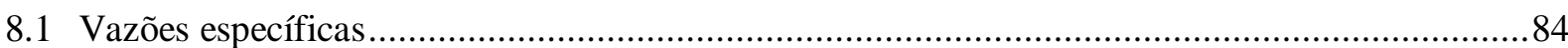

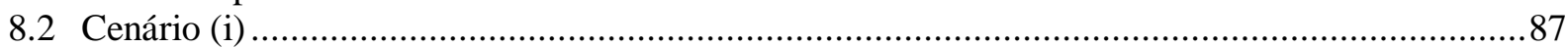

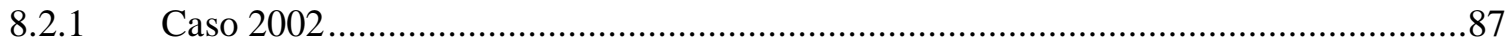

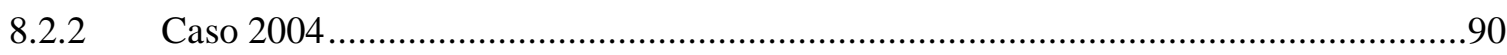

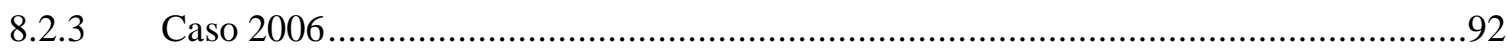

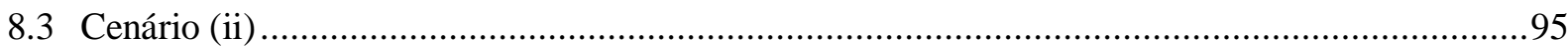

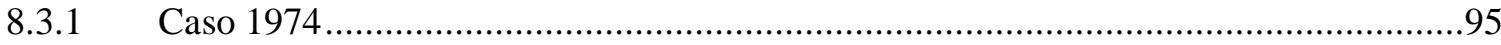

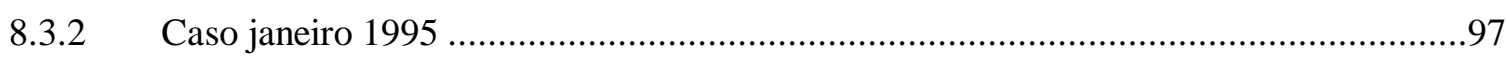

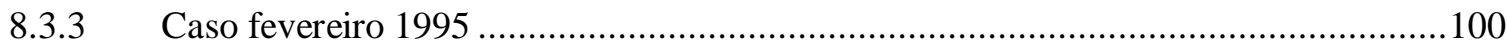

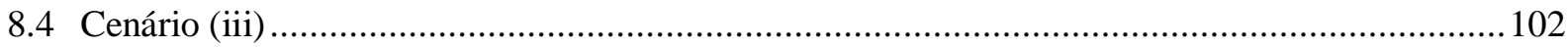

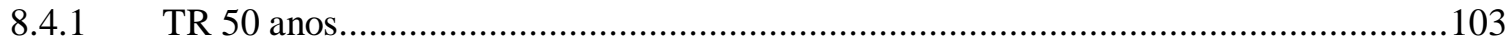

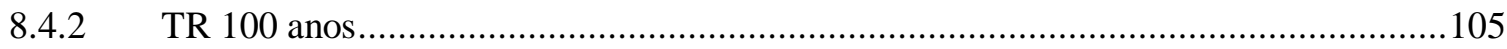

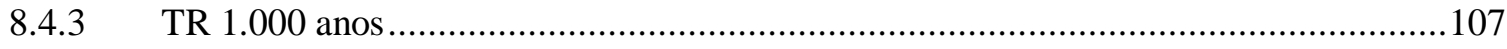

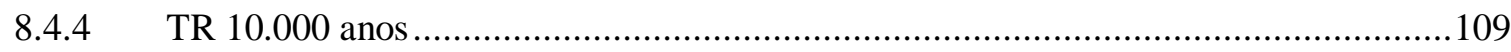

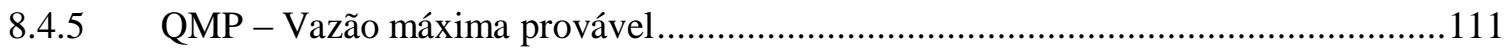

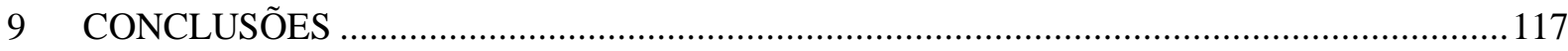

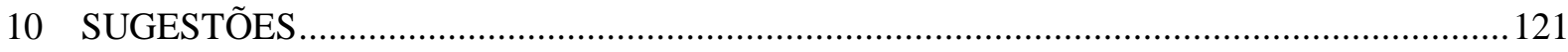

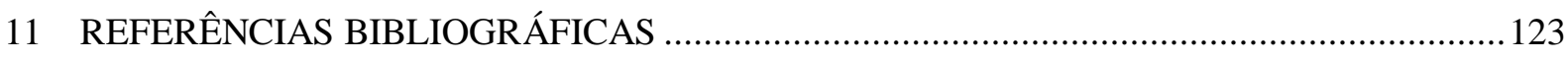

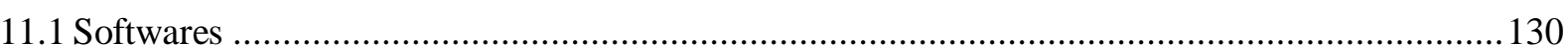

APÊNDICE A - Discussões acerca das inundações do rio Cuiabá e sua relação com a ocupação do solo urbano

APÊNDICE B - Estações fluviométricas e seções topobatimétricas nos rios Cuiabá e Manso ...........140

APÊNDICE C - Seções topobatimétricas dos rios Cuiabá e Manso ................................................... 141

ANEXO A - Características principais da UHE Manso...................................................................... 144

ANEXO B - Topobatimetria nos rios Manso (ST 1 a ST 4) e Cuiabá (ST 5 a ST 16) ........................ 146 





\section{RESUMO}

DE PAES, R. P. (2011). Análise da translação da onda de cheia efluente do reservatório da UHE Manso na bacia hidrográfica do rio Cuiabá, Mato Grosso. Dissertação de Mestrado pelo Programa de Pós-graduação em Engenharia Hidráulica e Saneamento: EESC/USP. São Carlos, SP. 158p.

As inundações periódicas na bacia hidrográfica do rio Cuiabá levaram a população a buscar meios para controlar as ocorrências de inundação, o que estimulou a construção da UHE Manso, atualmente sob responsabilidade da empresa Eletrobrás Furnas, em importante afluente desse rio. A partir de então, muito se tem discutido sobre a segurança proporcionada pela contenção de cheias do Aproveitamento Múltiplo de Manso (APM Manso) nas comunidades a jusante, especialmente na região metropolitana do Vale do Rio Cuiabá. O presente trabalho se propõe a avaliar a influência do reservatório de Manso na atenuação das cheias na bacia do Cuiabá. Foram analisados cenários hidráulicos a fim de comparar o impacto dos eventos extremos que ocorreram antes e após a operação da usina nas hipóteses da existência e inexistência do reservatório, e de cheias de projeto com diversos períodos de retorno na sub-bacia do rio Manso. O amortecimento hipotético do APM Manso foi simulado pelo método de Puls, e a translação da onda de cheia foi calculada pelo modelo hidrodinâmico CLiv. Em suma, foi constatado que o reservatório evitou uma cheia que atingiria grandes magnitudes em 2006. Quanto às inundações de maior prejuízo observadas anteriormente à construção da usina, duas delas seriam substancialmente atenuadas com a existência do reservatório; no entanto, uma terceira atingiria os níveis de alerta definidos pela Defesa Civil Estadual. Por fim, concluiu-se que, nas condições ideais de simulação, o APM Manso é capaz de reduzir a frequência das cheias consideradas de risco para as comunidades a jusante para períodos de retorno entre 50 e 100 anos. Apesar do amortecimento verificado, para que haja mitigação dos impactos de maneira racional, diversos outros cuidados devem ser tomados, em especial os relacionados ao planejamento para a ocupação apropriada das áreas de planície de inundação, a fim de que a segurança da população não dependa exclusivamente do reservatório.

Palavras-chave: Hidráulica fluvial, amortecimento de reservatório, modelo hidrodinâmico, inundação fluvial, análise de cheia, bacia hidrográfica do rio Cuiabá. 





\begin{abstract}
DE PAES, R. P. (2011). Flood routing analysis of Manso hydroelectric power plant effluent reservoir in Cuiabá river basin, Mato Grosso state, Brazil. Dissertation for Postgraduation Program of Hydraulic and Sanitation Engineering: EESC/USP, São Carlos. $158 \mathrm{p}$.

The constant floods in Cuiabá river basin had led population to seek ways to control the overflow occurrences, encouraging the construction of Manso hydroelectric power plant, nowadays under responsibility of Eletrobras Furnas Company, in an important tributary of this river. Much has been discussed about the safety provided by the flood attenuation of Manso Multiple Use reservoir (MMU) in downstream communities, mainly in the metropolitan region of Cuiabá River Valley. In this context, this dissertation reports on the evaluation of the influence of Manso reservoir on the flood attenuation in Cuiabá basin. Hydraulic scenarios were analyzed in order to compare the impact of extreme events that occurred before and after hydroelectric power plant operation in the case of existence and non existence of the reservoir, and the impact of design flood with many return periods in Manso river sub-basin. The hypothetical flood-control of the MMU was simulated by level pool routing method, and the wave propagation was calculated by CLiv hydrodynamic model. It was verified that the reservoir avoided an inundation of great magnitudes in 2006. Regarding the major inundations that occurred before the hydroelectric power plant construction, two of them would have been substantially attenuated by the existence of the reservoir, and a third one would have reached the alert levels defined by the State Civil Defense. Finally, it was concluded that, under perfect simulated conditions, MMU is able to reduce the flood frequency considered risky to communities downstream in return periods between 50 and 100 years. Despite the verified flood-control, for the purpose of mitigating the impacts in wise manners, many other precautions must be taken, especially those related to planning for appropriate occupation in flood plain areas, so that population safety does not depend exclusively on the reservoir.
\end{abstract}

Keywords: Fluvial hydraulic, flood-control reservoir, hydrodynamic model, river inundation, flood analysis, Cuiabá river basin 


\section{LISTA DE FIGURAS}

Figura 1 - Níveis de água superiores ao de emergência, em Cuiabá .................................................................

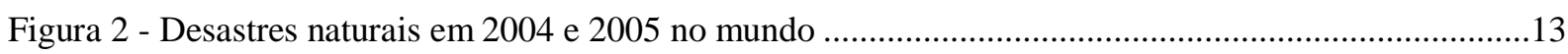

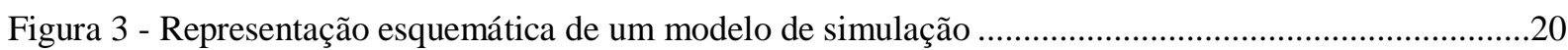

Figura 4 - Curvas de descarga para a regra operacional de comportas em um reservatório ............................47

Figura 5 - Hidrogramas de entrada e saída de água em um reservatório ......................................................47

Figura 6 - Região hidrográfica do Alto Paraguai e da BHC na América do Sul...........................................49

Figura 7 - Cotas de fundo dos rios Manso e Cuiabá, da UHE Manso (montante) até o município de

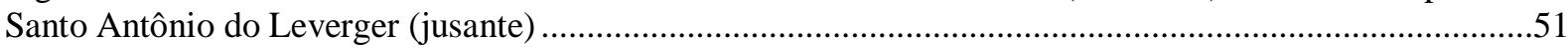

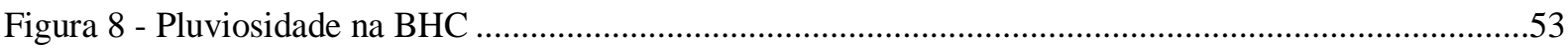

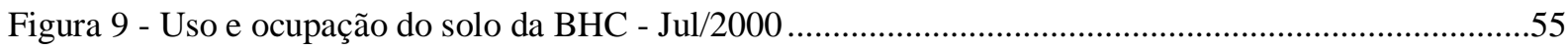

Figura 10 - Zonas de influência das estações fluviométricas da BHC .........................................................74

Figura 11 - Zonas de influência das estações fluviométricas da BHC para o cenário (iii) ..............................75

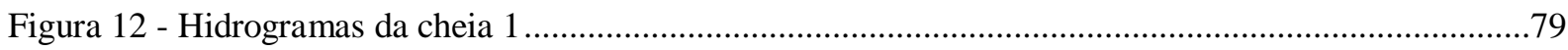

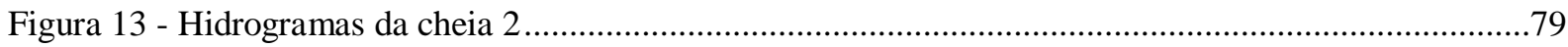

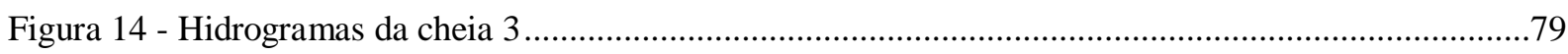

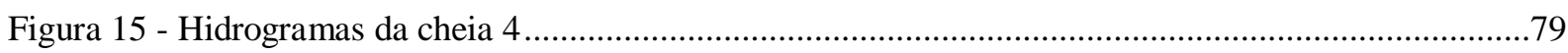

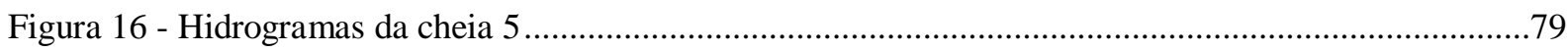

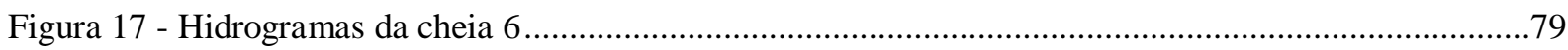

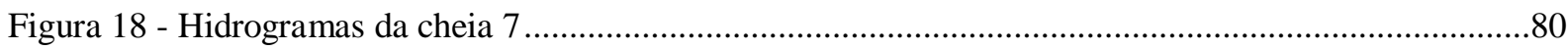

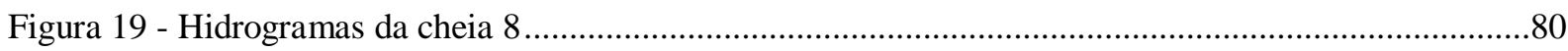

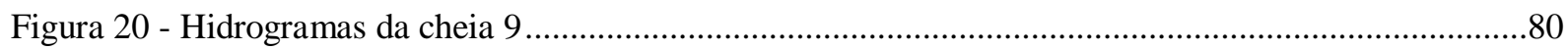

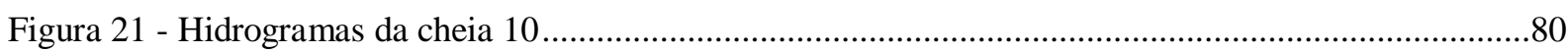

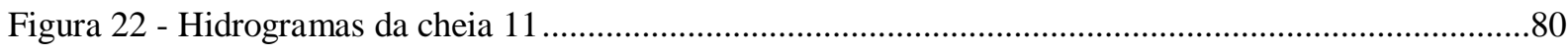

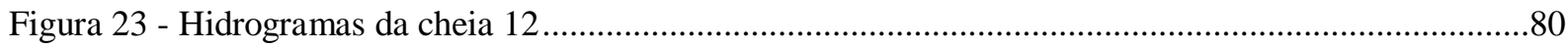

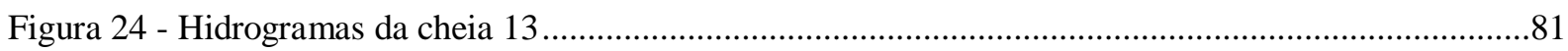

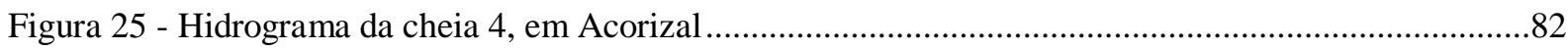

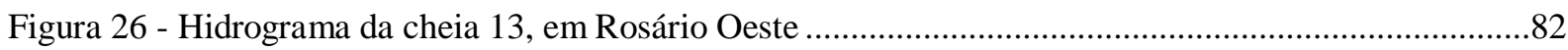

Figura 27 - Vazões específicas referentes às zonas de influência de cada estação fluviométrica para as

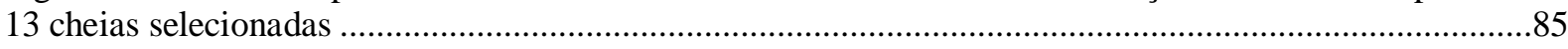

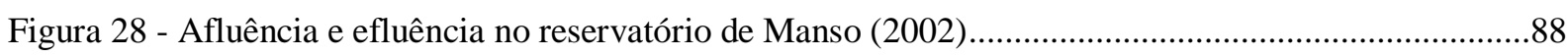

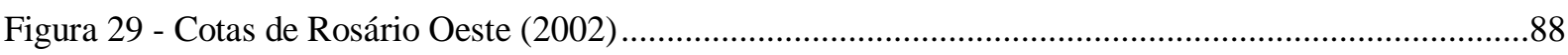

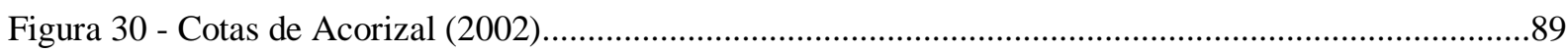

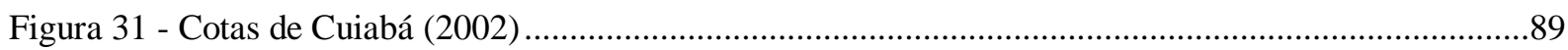

Figura 32 - Afluência e efluência no reservatório de Manso (2004).........................................................90

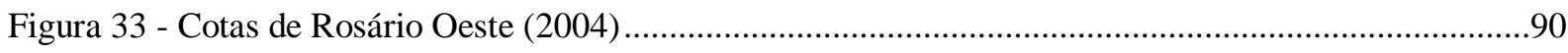

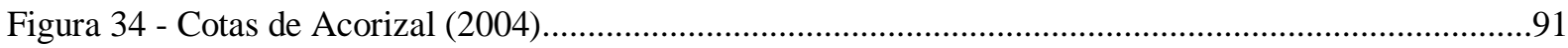

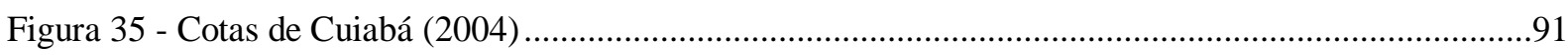

Figura 36 - Afluência e efluência no reservatório de Manso (2006).........................................................92

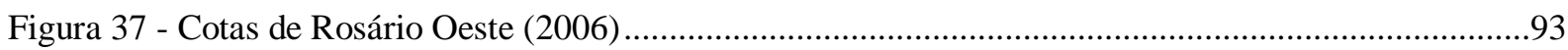

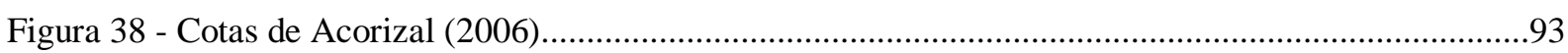

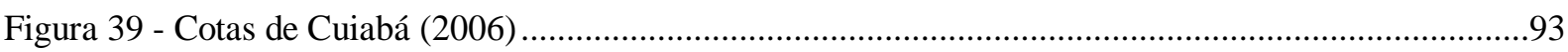

Figura 40 - Vazões registradas e teoricamente amortecidas (1974).........................................................96

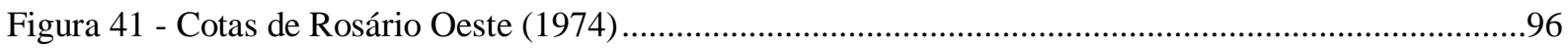




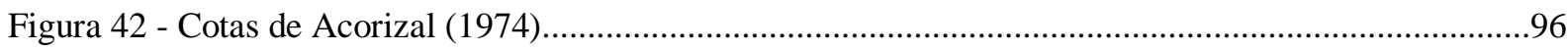

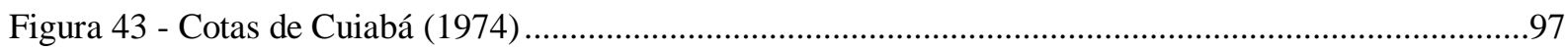

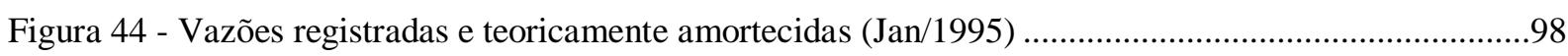

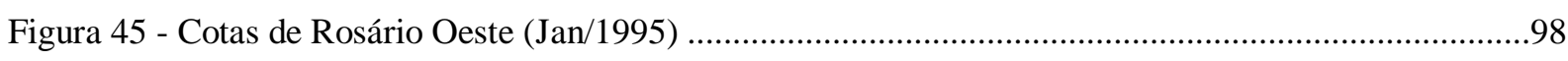

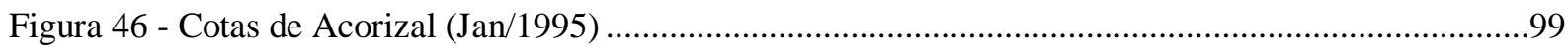

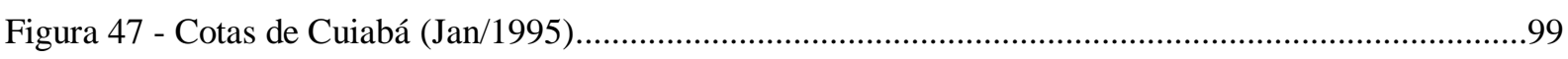

Figura 48 - Vazões registradas e teoricamente amortecidas (Fev/1995) .....................................................100

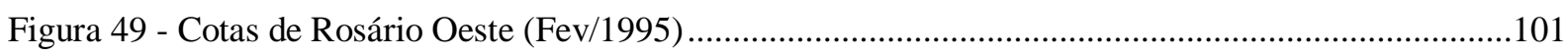

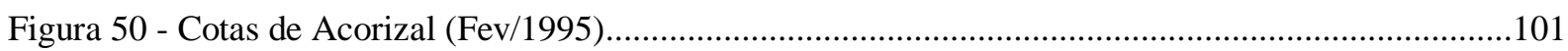

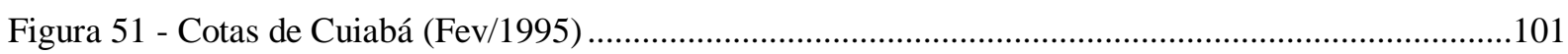

Figura 52 - Amortecimento da cheia de projeto TR 50 anos no rio Manso ...............................................103

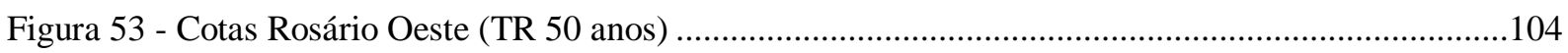

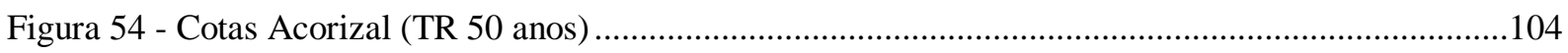

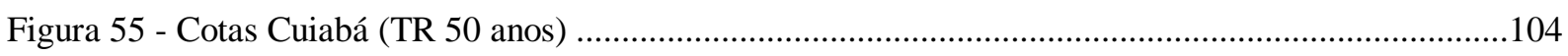

Figura 56 - Amortecimento da cheia de projeto TR 100 anos no rio Manso .............................................105

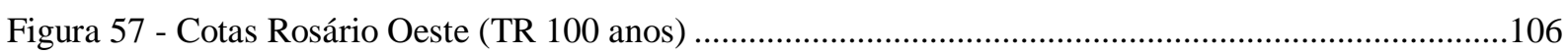

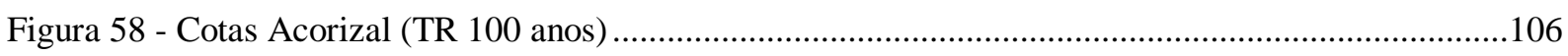

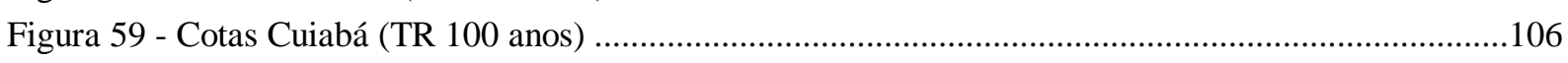

Figura 60 - Amortecimento da cheia de projeto TR 1.000 anos no rio Manso ………….............................107

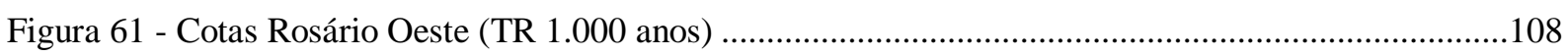

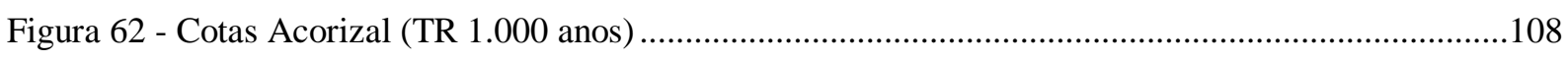

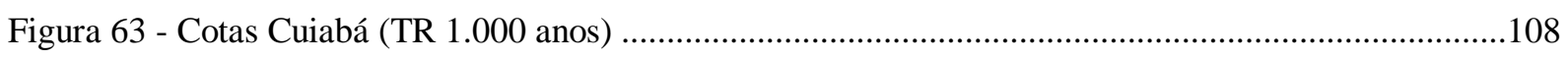

Figura 64 - Amortecimento da cheia de projeto TR 10.000 anos no rio Manso ...........................................109

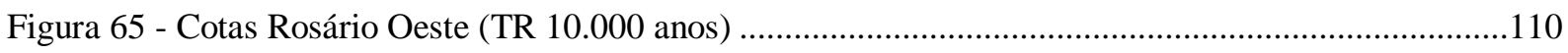

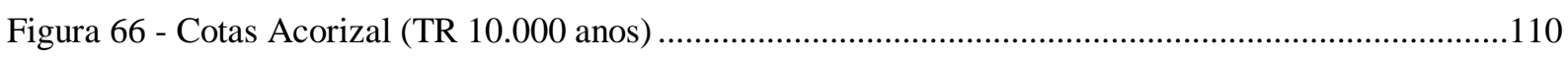

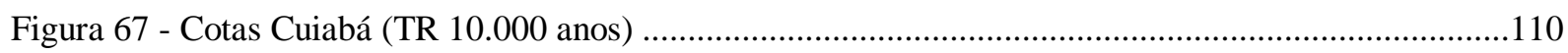

Figura 68 - Amortecimento da cheia de projeto QMP no rio Manso ......................................................112

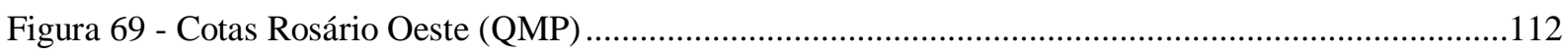

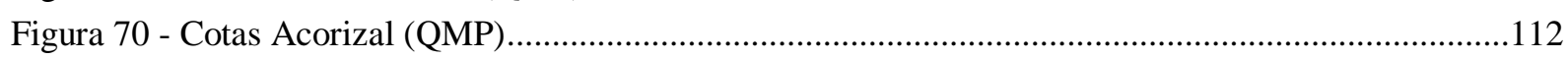

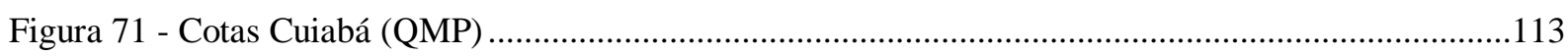

Figura 72 - Níveis de água em Rosário Oeste em função de cheias com diversos períodos de retorno

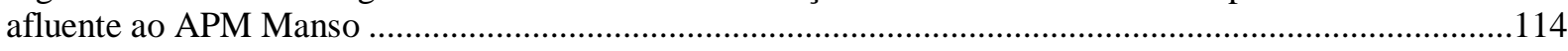

Figura 73 - Níveis de água em Acorizal em função de cheias com diversos períodos de retorno afluente

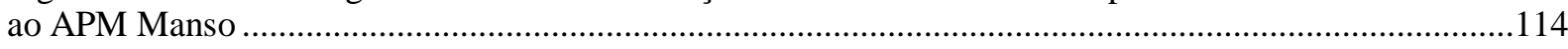

Figura 74 - Níveis de água em Cuiabá em função de cheias com diversos períodos de retorno afluente ao

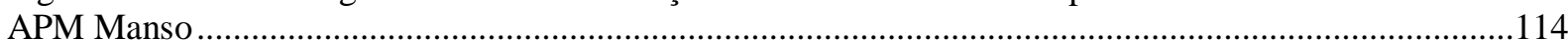

Figura 75 - NA do rio Cuiabá na Av. 15 de Novembro, em Cuiabá (1974) ...............................................132

Figura 76 - Cota ortométrica correspondente ao do NA máximo em 1974 na Av. 15 de Novembro

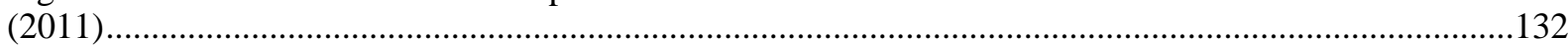

Figura 77 - Inundação no bairro do Terceiro. Destaque: futura ocupação São Mateus (1974) .....................133

Figura 78 - Regional leste de Cuiabá. Destaque: ocupação São Mateus (2010) ..........................................134

Figura 79 - Inundação no bairro Praerinho. Destaque: futuro residencial (1995) .........................................136

Figura 80 - Bairro Praerinho. Destaque: construção do residencial (2009) ................................................136 


\section{LISTA DE TABELAS E QUADRO}

Tabela 1 - Registros linimétricos com valores superiores ao nível de emergência em Cuiabá (9,50 m) e as cotas ortométricas correspondentes

Tabela 2 - Classificações dos modelos de escoamento .........................................................................26

Tabela 3 - Declividades dos rios Manso e Cuiabá, da UHE Manso (montante) até o município de Santo

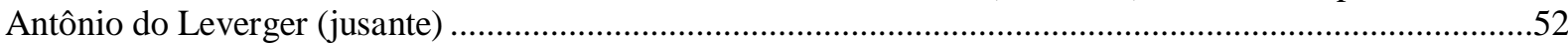

Tabela 4 - Simulações realizadas para cada cenário .....................................................................62

Tabela 5 - Estações fluviométricas utilizadas para obtenção dos hidrogramas.........................................64

Tabela 6 - Maiores cheias em Cuiabá com disponibilidade de vazão nas principais estações

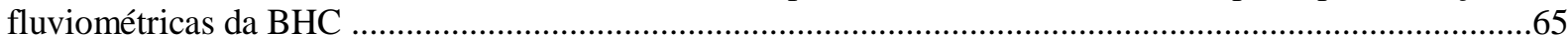

Tabela 7 - Seções topobatimétricas nos rios Manso e Cuiabá .................................................................67

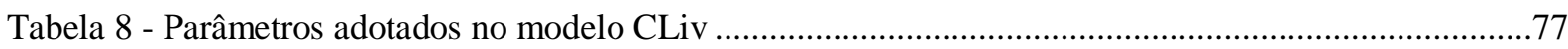

Tabela 9 - EPVP, EQRM e Nash-Sutcliffe entre os hidrogramas observados e calculados ........................78

Tabela 10 - Níveis de água e cotas ortométricas correspondentes aos limites de segurança em Rosário

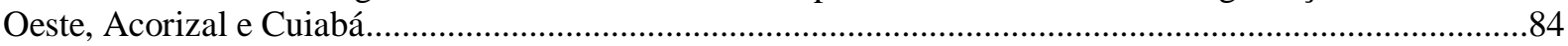

Tabela 11 - Vazão específica média da BHC com exceção das sub-bacias do Manso e do Alto Cuiabá ......84

Tabela 12 - Vazão específica média da BHC com exceção da sub-bacia do Manso ....................................86

Tabela 13 - Vazões específicas para o Cenário (iii) ...........................................................................87

Quadro 1 - Classificações e descrições de modelos conforme os seus critérios........................................22 


\section{LISTA DE SIGLAS E SÍMBOLOS MATEMÁTICOS}

Siglas

ANA - Agência Nacional de Águas

ANEEL - Agência Nacional de Energia Elétrica

APM Manso - Aproveitamento Múltiplo de Manso

APP - Área de Preservação Permanente

BHAC - Sub-bacia hidrográfica do Alto Cuiabá

BHC - Bacia hidrográfica do rio Cuiabá

BHM - Sub-bacia hidrográfica do Manso

CAEEB - Companhia Auxiliar de Empresas Elétricas Brasileiras

CAPES - Coordenação de aperfeiçoamento de pessoal de nível superior

CLiv - Software Condutos Livres (para o modelo hidrodinâmico)

Conama - Conselho Nacional do Meio Ambiente

DNOS - Departamento Nacional de Obras e Saneamento

DNPM - Departamento Nacional de Produção Mineral

GPS - Global Position System - Sistema de Posicionamento Global

IBGE - Instituto Brasileiro de Geografia e Estatística

IPDU - Instituto de Planejamento e Desenvolvimento Urbano de Cuiabá

ISDR - International Strategy for Disaster Reduction - Estratégia internacional para redução de desastres

ONS - Operador Nacional de Sistema

PAE - Plano de Ação de Emergência

PMC - Prefeitura Municipal de Cuiabá

PNSB - Política Nacional de Segurança de Barragens 
PROCAD - Programa Nacional de Cooperação Acadêmica

RBMC - Rede Brasileira de Monitoramento Contínuo

RHAP - Região hidrográfica do rio Alto Paraguai

SAD 69 - South American Datum 1969

SIG - Sistema de informações geográficas

SNDC - Sistema Nacional de Defesa Civil

SSD - Sistema de Suporte de Decisão

SUDEC/MT - Superintendência de Defesa Civil do Estado de Mato Grosso

UFMT - Universidade Federal de Mato Grosso

UHE Manso - Usina hidrelétrica de Manso

UNDRO - United Nations Disaster Relief Organization - Organização para socorro em desastres das Nações Unidas

USP - Universidade de São Paulo

\section{Símbolos Matemáticos}

$\mathrm{Q}=\operatorname{vazão}\left[\mathrm{m}^{3} \cdot \mathrm{s}^{-1}\right]$

$\mathrm{A}=$ área da seção molhada $\left[\mathrm{m}^{2}\right]$

$\mathrm{x}=$ distância no sentido longitudinal [m]

$\mathrm{t}=$ tempo $[\mathrm{s}]$

$\mathrm{q}$ = vazão por unidade de largura de contribuição lateral $\left[\left(\mathrm{m}^{3} \cdot \mathrm{s}^{-1}\right) \cdot \mathrm{m}^{-1}\right]$

$\mathrm{g}=$ aceleração da gravidade $\left[\mathrm{m} \cdot \mathrm{s}^{-2}\right]$

y = lâmina de água [m]

$\mathrm{S}_{0}=$ declividade do canal $\left[\mathrm{m} \cdot \mathrm{m}^{-1}\right]$

$\mathrm{S}_{\mathrm{f}}=$ declividade da linha de atrito $\left[\mathrm{m} \cdot \mathrm{m}^{-1}\right]$

Qmáx obs = Vazão máxima observada $\left[\mathrm{m}^{3} \cdot \mathrm{s}^{-1}\right]$

Qmáx calc $=$ Vazão máxima calculada $\left[\mathrm{m}^{3} \cdot \mathrm{s}^{-1}\right]$ 
Qobs $_{\mathrm{t}}=$ Vazão observada no tempo “t”" $\left[\mathrm{m}^{3} \cdot \mathrm{s}^{-1}\right]$

Qcalc $_{\mathrm{t}}=$ Vazão calculada no tempo " $\mathrm{t}$ " $\left[\mathrm{m}^{3} \cdot \mathrm{s}^{-1}\right]$

$\mathrm{n}^{\mathrm{o}}$ série_hist $=$ Número de registros na série histórica

$\mathrm{Qmobs}_{\mathrm{t}}=$ Vazão média observada no tempo “ $\mathrm{t}$ " $\left[\mathrm{m}^{3} \cdot \mathrm{s}^{-1}\right]$

$\mathrm{QE}_{\mathrm{t}}=$ Vazão de entrada no reservatório no tempo “ $\mathrm{t}$ " $\left[\mathrm{m}^{3} \cdot \mathrm{s}^{-1}\right]$

$\mathrm{QS}_{\mathrm{t}}=$ Vazão de saída do reservatório no tempo " $\mathrm{t}$ " $\left[\mathrm{m}^{3} \cdot \mathrm{s}^{-1}\right]$

$\Delta t=$ Intervalo de tempo, cuja unidade varia em função da discretização temporal

$\mathrm{V}_{\mathrm{t}} / \Delta \mathrm{t}=$ Volume de água armazenado no reservatório no intervalo de tempo " $\Delta t$ " $\left[\mathrm{m}^{3}\right]$

$\mathrm{C}=$ Coeficiente de descarga

$\mathrm{L}=$ Largura do vertedor $[\mathrm{m}]$

$\mathrm{H}$ = Carga equivalente ao nível de água sobre a crista do vertedor [m]

$\Delta \mathrm{H}^{*}=$ Diferença do nível de água que equivale à variação do volume do reservatório entre um intervalo de tempo

Qespec. вMC $=$ Vazão específica da área intermediária da BHC entre a UHE Manso e Cuiabá relativa à BMC $\left[\mathrm{L} . \mathrm{s}^{-1} \cdot \mathrm{km}^{-1}\right]$

Qcbá.t = Vazão registrada na estação fluviométrica Cuiabá no tempo “t” $\left[\mathrm{m}^{3} \cdot \mathrm{s}^{-1}\right]$

QQuebó.t-24h $=$ Vazão da estação Quebó no dia anterior $(\mathrm{t}-24 \mathrm{~h})\left[\mathrm{m}^{3} . \mathrm{s}^{-1}\right]$

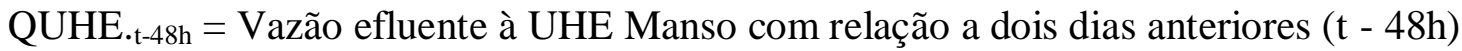
$\left[\mathrm{m}^{3} \cdot \mathrm{s}^{-1}\right]$

D UHE Manso-Cbá = Distância entre as estações fluviométricas da UHE Manso e Cuiabá, pelo rio principal, equivalente a $285,58 \mathrm{~km}$

Qespec. BMC+BAC $=$ Vazão específica da área intermediária da BHC entre a UHE Manso e Cuiabá relativa à $\mathrm{BMC}$ e à $\mathrm{BAC}\left[\mathrm{L} \cdot \mathrm{s}^{-1} \cdot \mathrm{km}^{-1}\right]$

EPVP = Erro percentual da vazão de pico

$\mathrm{EQRM}=$ Erro quadrático relativo médio

NS = Coeficiente de eficiência de Nash-Sutcliffe 





\section{INTRODUÇÃO}

\subsection{Cheias e inundações}

As cheias em um sistema fluvial são fenômenos naturais verificados em qualquer parte do globo terrestre. Elas são resultado do aumento do nível médio de água em um sistema hídrico, e não necessariamente causam prejuízos à população. Contudo, frequentemente ganham proporções suficientes para extrapolar o leito menor de um curso de água. Brasil (2007) define inundação como o extravasamento desse leito menor, o qual pode atingir territórios urbanos ou rurais.

A ocorrência de cheias e inundações é função, principalmente, de características inerentes à bacia hidrográfica. Está envolvido neste processo a sua pluviosidade, o formato da bacia, que se reflete no tempo de concentração das suas águas, o potencial de evapotranspiração, a conformação topográfica, a composição pedológica, o tipo de cobertura vegetal, o uso e ocupação do solo, entre outros. A atividade antropogênica, muitas vezes responsáveis pelo desmatamento e assoreamento, impermeabilização, ocupação irregular do solo e retificação de canais naturais, é fator relevante no aumento da ocorrência de cheias desastrosas.

Entre as conseqüências que esses fenômenos podem provocar em maior ou menor escala são citados: perda material, o qual se inclui a habitação; a interdição de vias de acesso; processos de realocação de desabrigados; interrupção das atividades econômicas na área inundada; suspensão parcial ou total dos serviços de infraestrutura básica na área abrangida, como os de saneamento básico: atendimento à coleta de resíduos sólidos, serviços de água potável e esgotamento sanitário; além das dificuldades no atendimento de serviços de saúde e no fornecimento de alimentação. Outra conseqüência de ordem mais importante em relação às inundações e enxurradas é a possibilidade de perda de vidas humanas.

Há um rol de maneiras para se agir em favor da redução de impactos que os desastres naturais, como as enchentes, podem causar à população em uma bacia hidrográfica. Elas são classificadas como medidas estruturais e não-estruturais. As medidas não-estruturais geralmente têm cunho mitigador, e envolvem ações relacionadas às políticas urbanas, planejamento urbano, legislação, planos de Defesa Civil e educação, como por exemplo, a 
elaboração de mapas de áreas de risco, regulamentação do uso da terra, elaboração de planos emergenciais e cálculos de otimização para operação de reservatórios. Enquanto as medidas estruturais consistem em ações de ordem física e normalmente têm custo mais elevado, como obras de proteção da superfície, construção de diques, modificação dos canais fluviais e de reservatórios de amortecimento.

\subsection{Cheias na bacia hidrográfica de Cuiabá}

A população do município de Cuiabá e região registra ao longo dos anos ocorrências cíclicas de enchentes e estiagens, em conformidade com os períodos hidrológicos, que assim contribuem significativamente com o estabelecimento da dinâmica fluvial da planície pantaneira.

Um levantamento realizado na bacia hidrográfica do rio Cuiabá (BHC) apontou sete municípios a ela pertencentes que normalmente são atingidos por inundações (SAAF, 2003), entre os quais cinco - Nobres, Cuiabá, Várzea Grande, Santo Antônio do Leverger e Barão de Melgaço - são banhados pelo rio Cuiabá. Shirashi (2003) indica ainda outros dois municípios

- Rosário Oeste e Acorizal - também banhados por este rio e que são prejudicados pelas cheias periódicas.

Pela frequência desses fenômenos, em especial os que atingem a população, a Superintendência de Defesa Civil do Estado de Mato Grosso (SUDEC/MT) estipulou níveis linimétricos de referência a diversos rios do estado em localidades com potencial de inundação, como nos rios Paraguai, Araguaia, Jangada e Guaporé. No rio Cuiabá, a SUDEC/MT considerou as experiências de áreas alagáveis a montante do Pantanal e adotou, por exemplo, os níveis de alerta $(8,50 \mathrm{~m})$, emergência $(9,50 \mathrm{~m})$ e calamidade $(11,00 \mathrm{~m})$ na capital do estado.

Desde o início da operação da estação fluviométrica de Cuiabá, em 1933, a lâmina de água esteve por 19 vezes acima do nível de alerta, entre elas, seis acima do nível de emergência. Ao estudar as frequiências dessas situações, Shirashi (2003) apontou que há probabilidade de ocorrência de alturas de água acima dos níveis de alerta e de emergência, respectivamente, a cada 5 e 15 anos. 
Um levantamento histórico-bibliográfico realizado por Pedrollo e De Paes ${ }^{1}$ (em fase de elaboração) indicou ainda outros seis fenômenos de inundação anteriores a 1933 em Cuiabá, sendo o primeiro em 1780. Os autores alertam que isso não significa que essas foram as únicas ocorrências desde a primeira documentada, já que a cidade foi fundada em 1719. Nesse trabalho foram discriminadas algumas das consequências dessas inundações desde o século XVIII até os dias atuais, as quais provocaram danos à “[...] máquina da estação hidráulica, [...] obrigando a população a servir-se de águas de chuvas e das cisternas, uma vez que a máquina era movida a vapor"; obstrução de vias de acesso como ruas, avenidas, e pontes; destruição de edificações residenciais e comerciais, entre elas de armazenamento de alimentos para a cidade; remoção de milhares de residências; e perdas de vidas humanas.

A Tabela 1 apresenta os maiores níveis linimétricos de cada ocorrência com valores superiores ao nível de emergência na estação fluviométrica de Cuiabá durante a série histórica de 1933 a 2010, segundo as informações da Agência Nacional de Águas (ANA). O nível de emergência já era suficiente para causar graves prejuízos aos moradores da BHC mesmo no início do século XX, antes ainda da explosão populacional das décadas de 1960 e 1970.

\begin{tabular}{lll}
\multicolumn{3}{l}{$\begin{array}{l}\text { Tabela 1 - Registros linimétricos com valores superiores ao nível de } \\
\text { emergência em Cuiabá }\end{array}$} \\
\hline M,50 m) e as cotas ortométricas correspondentes
\end{tabular}

Fonte: ANA

A Figura 1 representa a lâmina de água equivalente a essas ocorrências, em função do tempo, na mesma estação fluviométrica, onde é possível visualizar que em algumas cheias a situação de calamidade esteve próxima de acontecer.

\footnotetext{
${ }^{1}$ PEDROLLO, J.M.; DE PAES, R.P. Enchentes do rio Cuiabá e sua relação com a ocupação do solo urbano. Artigo a ser publicado. Cuiabá - MT.
} 


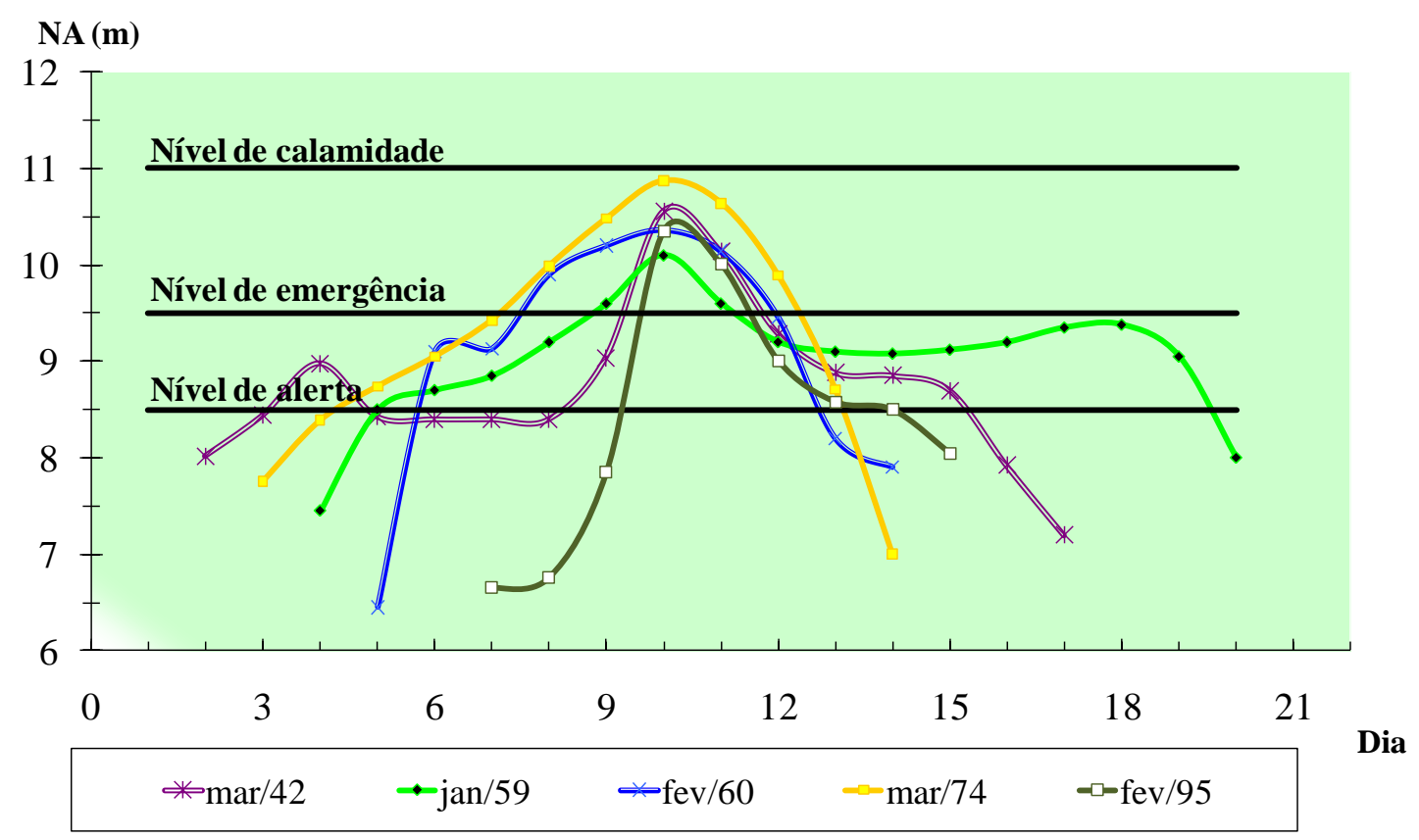

Figura 1 - Níveis de água superiores ao de emergência, em Cuiabá Fonte: ANA

Observação interessante quanto aos prejuízos na bacia é em relação ao tempo de permanência dos elevados níveis de água. Enquanto em fevereiro de 1995 o nível de água esteve superior ao equivalente à alerta durante cinco dias, em janeiro de 1959 a exposição foi de quinze dias.

A definição do nível de água na questão sobre os prejuízos decorrentes das cheias fluviais na bacia pode ser menos importante que o ano em que elas acontecem. Como exemplo, as ocorrências das décadas de 1950 e 1960 resultaram em menos danos que as da década de 1990, em função da ocupação populacional.

Pelos transtornos causados, as inundações de 1974 e 1995 merecem destaque entre as demais. De acordo com a Memória Técnica do Aproveitamento Múltiplo de Manso (FURNAS, 2002), a grande inundação de 1974 atingiu cerca de $13 \mathrm{~km}^{2}$ de área urbanizada. Foram afetadas aproximadamente 2.400 edificações residenciais e comerciais, que abrigavam população estimada em 12 mil pessoas, com prejuízos financeiros estimados na ordem de milhões de dólares. Pedrollo e De Paes (em fase de elaboração) destacam que foi necessária a intervenção da Força Aérea Brasileira e Ministério do Interior no atendimento às vitimas. $\mathrm{O}$ fenômeno de 1974 foi ainda responsável pela decisão de demolição do bairro do Terceiro por parte de diversos órgãos governamentais. $\mathrm{O}$ bairro se localizava em área de várzea e era constantemente exposto às enchentes. A população seria realocada em outros locais, o que de 
fato não ocorreu. Este episódio incitou a migração desordenada para diversas outras localidades da cidade, muitas das quais para outras áreas inapropriadas.

Apesar de a enchente de 1974 ter atingido nível fluviométrico superior à de 1995, os prejuízos desta mais recente foram maiores devido ao aumento da densidade populacional nas áreas de risco, fato agravado pela ocupação e pela impermeabilização do solo sem critérios suficientemente apropriados. Além dos danos aos equipamentos públicos, a SUDEC/MT estimou em 86 mil o número de desabrigados no ano de 1995 em Mato Grosso (FURNAS, 2002), resultado principalmente da inundação do rio Cuiabá e dos seus afluentes urbanos remansados; enquanto o Instituto de Planejamento e Desenvolvimento Urbano (IPDU) estimou, com base nas cotas atingidas pelo rio Cuiabá e na ocupação urbana, em 7.750 desabrigados na capital do estado nesta mesma ocorrência (CUIABÁ, 1999).

\subsection{Amortecimento da onda de cheia - UHE Manso}

Pelos agravos ocorridos a partir de 1974, ficou ressaltada a importância de medidas que amenizassem o impacto das cheias na bacia do rio Cuiabá. Dentro da ótica das ações estruturais, evoluíram-se os estudos básicos para a implantação de um a três reservatórios a montante de Cuiabá com a finalidade inicial de contenção de cheias; posteriormente objetivou-se, também, a produção de energia elétrica. A hipótese de construção de reservatórios a montante da capital já existia nos planos do poder público federal através do Departamento Nacional de Produção Mineral (DNPM) e se intensificou a partir de 1974, por meio do Departamento Nacional de Obras e Saneamento (DNOS) e da Companhia Auxiliar de Empresas Elétricas Brasileiras (CAEEB).

Depois de avaliadas as proposições, no início dos anos 1980 foi sugerida a construção de uma barragem no rio Manso imediatamente a jusante da foz do rio da Casca, no município de Chapada dos Guimarães. A regularização da vazão pela estrutura hidráulica possibilitaria reduzir o pico de cheia e aumentar o tempo de base dos hidrogramas máximos acumulados no reservatório.

A execução das obras da UHE Manso teve início em setembro de 1988. Por motivos financeiros e de falta de informações hidrometeorológicas que permitissem com relativa segurança avaliar os efeitos da usina, houve expressivo atraso na construção do empreendimento, o qual foi paralisado em 1989 e retomado, em definitivo, somente após 
nove anos, em 1998. Segundo Furnas (2002), adaptações à legislação vigente precisaram ser consideradas para o reinício das obras, como o atendimento à Resolução n. ${ }^{\circ} 001$ de 1986 do Conselho Nacional do Meio Ambiente (Conama), que especificou critérios básicos e diretrizes gerais para uso e implementação da avaliação de impacto ambiental. Uma das exigências legais foi a ampliação dos estudos ambientais e a organização de audiência pública. Assim, a UHE Manso foi o primeiro empreendimento dessa categoria a realizá-la no Brasil. Em consideração às novas leis ambientais, o nome do projeto foi alterado para Aproveitamento Múltiplo de Manso (APM Manso). Ficou destacado assim o fundamento de multifinalidade do uso da água previsto na legislação brasileira dos recursos hídricos.

Furnas (2002) elenca os diversos objetivos para qual o reservatório do APM Manso foi construído: (i) suprimento de energia elétrica ao sistema Sudeste/Centro-Oeste, em especial o sistema interligado de Mato Grosso; (ii) proteção contra as cheias no vale do rio Cuiabá, notadamente nas cidades de Cuiabá e Várzea Grande; (iii) melhoria nas condições de navegabilidade no rio Cuiabá pelo aumento do tirante de água durante a estiagem; (iv) majoração da disponibilidade de água para irrigação nas localidades a montante do reservatório, ou mesmo a jusante, devido à garantia de vazão mínima do rio Cuiabá; (v) melhoria da qualidade da água do rio Cuiabá próximo às zonas urbanas, já que a garantia de vazões mínimas favorece a diluição de efluentes; (vi) desenvolvimento de polo turístico propiciado pelo reservatório do APM Manso.

O fechamento das comportas da UHE Manso para o acúmulo de água no reservatório ocorreu em novembro de 1999 e o funcionamento da primeira turbina em novembro de 2000, sob a responsabilidade da empresa Furnas Centrais Elétricas S.A., hoje denominada Eletrobrás Furnas. O reservatório do APM Manso foi dimensionado com volume de espera capaz de conter, de forma integral, cheias afluentes à UHE Manso com período de retorno de até 20 anos (FURNAS, 2002). O ANEXO A apresenta as principais características da UHE Manso.

Como consequência do controle do nível do rio Cuiabá proporcionado pelo APM Manso, Pedrollo e De Paes (em fase de elaboração) relatam a existência de especulação pelo mercado imobiliário para a alteração do nível fluviométrico definido como de alerta, de emergência e de calamidade com o fim de urbanização das áreas abaixo da cota ortométrica $150 \mathrm{~m}$ - considerada planície de inundação pela Carta Geotécnica de Cuiabá (1990). No entanto, não há documentação expedida pela empresa Eletrobrás Furnas, responsável pela UHE Manso, ou qualquer outra entidade, atestando qual o domínio da represa sob as cheias 
do rio Cuiabá, ou, ao menos, a sugestão de altitude ortométrica para possível ocupação sem riscos à população.

Em consideração à consulta da Prefeitura Municipal de Cuiabá (PMC) a respeito da interferência do APM Manso no controle de cheias para ocupação urbana, Furnas (2008) exaltou a bacia intermediária entre a usina e o município. A empresa justificou a reduzida influência que possui sobre o rio Cuiabá nesta cidade resumindo as explicações ao suscitar o período de abril de 2001 em que houve elevação no nível de água na capital em função da grande precipitação no entorno da cidade, mas não ao alcance do reservatório. Por fim, no mesmo documento, comunicou “[...] que a matéria em questão é de competência do município, regulamentada na Lei de Uso e Ocupação do Solo de Cuiabá". Dessa maneira a empresa eximiu-se, sabiamente, de quaisquer responsabilidades sobre a definição de área segura para ocupação da população.

Em vista do impasse, o poder público municipal passou a autorizar a construção de edificações na planície de inundação, contanto que houvesse o seu aterramento até a cota ortométrica mínima de segurança, em torno de 150 m, e a manutenção da área de preservação permanente (APP) estabelecida pelo Código Florestal Brasileiro, Lei Federal n. ${ }^{\circ}$ 4.771/1965 (BRASIL, 1965), de $100 \mathrm{~m}$ para cursos de água com largura entre 50 e $200 \mathrm{~m}$. Cabe ressaltar que com essa medida, existe a tendência de limitação da planície fluvial à exata extensão da APP, além de redução das curvas do canal natural e da impermeabilização. Isso resulta na redução do tempo de concentração da bacia e da infiltração de água no solo, portanto, no acréscimo de vazões do rio para a mesma cheia hidrológica.

Depois de fechadas as comportas para funcionamento da UHE Manso, o reservatório mostrou-se útil ao amortecimento de cheias em algumas ocasiões e, desde então, não houve ocorrência de níveis de água superiores ao de alerta. Apesar disso, alguns fatos provocaram certa insegurança à população a jusante da usina. Por exemplo, no início de 2006 houve elevada pluviosidade em toda a BHC durante os meses de fevereiro e março. O volume de água do reservatório aumentou consideravelmente, e, por necessidade de manutenções, segundo Jordão (2006), as quatro comportas precisaram ser abertas.

A medida exaltou a população a jusante da barragem por alguns dias. Houve reconhecimento de risco de inundação pelos poderes públicos estadual e municipais e significativa cobertura da imprensa local. O aumento do nível de água do rio Cuiabá implicou 
algumas consequências: (i) afluentes urbanos do rio Cuiabá passaram por processo de remanso, expondo os ribeirinhos a risco; (ii) algumas escolas situadas próximo aos cursos de água liberaram seus alunos das aulas, os quais foram orientados a avisar suas famílias sobre a possibilidade de inundação nas residências próximas a estes corpos hídricos, (iii) houve reuniões oficiais, inclusive com a participação de representantes do exército brasileiro, assim como do primeiro escalão do governo do Estado e dos municípios de Cuiabá e Várzea Grande, o que sugeriu a importância do acontecimento e a indefinição quanto ao que poderia suceder (PEDROLLO e DE PAES, em fase de elaboração). Nessas reuniões, o poder público discutia um plano de ação caso houvesse inundação na zona urbana. Houve monitoramento contínuo por parte das autoridades, que disponibilizaram ginásios poliesportivos para abrigar os possíveis flagelados. Felizmente, com o cessar das chuvas nos dias seguintes, o nível de água desceu, reduzindo a apreensão da população. O APM Manso teve relativo sucesso como retentor das cheias da bacia do rio Cuiabá, apesar dos riscos e possibilidade de não atendimento pleno da meta.

Deve-se considerar que grande parte da água responsável pelas enchentes do rio Cuiabá na capital provém da área intermediária entre a barragem de Manso e a cidade, isso torna impraticável a definição de cota segura. O trajeto UHE Manso - Cuiabá pelo canal fluvial tem aproximadamente $285 \mathrm{~km}$. A quantidade de água gerada na bacia incremental equivale a 51\%, em média, o total da bacia do rio Cuiabá. Há relativa variação nesses índices, com maior representatividade entre o período de chuvas, $62 \%$, que durante a estiagem, $30 \%$ (FURNAS, 2002).

A esse respeito, Oliveira (2003) comenta que "[...] a decisão operativa sobre a vazão efluente [à barragem] ocorre com uma antecedência média de 2 dias, e após esta decisão, não há mais interferência da usina". A autora alerta que no caso de ocorrerem chuvas convectivas locais a jusante do reservatório, com acréscimo significativo de vazões incrementais, essas águas, somadas à efluência da usina, podem provocar inundações, restando como única medida o alerta à população a jusante.

A magnitude da área incremental, aproximadamente $14.200 \mathrm{~km}^{2}$ até Cuiabá, colabora sobremaneira com a dificuldade para o controle da inundação do rio Cuiabá. Evidencia-se, então, que tais ocorrências indesejadas só são possíveis graças à contribuição da área intermediária entre a usina de Manso e os municípios a jusante.

A Lei Federal n. ${ }^{\circ} 12.334$ de 2010 (BRASIL, 2010a), que entre outros estabelece a Política Nacional de Segurança de Barragens, define que o Plano de Ação de Emergência 
(PAE) deverá ser elaborado se o dano potencial associado à barragem for classificado como alto. Essa classificação é realizada em função da possibilidade de perdas de vidas humanas e dos impactos econômicos, sociais e ambientais decorrentes da ruptura da barragem. O PAE deve contemplar, por exemplo, informações a respeito da identificação e análise das possíveis situações de emergência e os procedimentos preventivos e corretivos a serem adotados nessas situações. Nessa conjuntura, é importante o conhecimento das prováveis áreas atingidas em casos extremos para que se possam ser executadas as ações de segurança à população, assim como a mitigação dos prejuízos associados a essas ocorrências.

Independente de qualquer aparato legal é indiscutível a necessidade de melhor conhecer o comportamento dos rios Manso e Cuiabá para a segurança da população a jusante da usina que ali reside e às futuras ocupações humanas, seja em relação à controvertida redução da cota da planície de inundação, seja para a elaboração de sistemas de alerta e planos emergenciais.

Por se tratar de uma questão crucial que afeta um segmento substancial da sociedade residente em diversos municípios mato-grossenses, é de extrema importância o desenvolvimento de pesquisas relacionadas aos efeitos das enchentes de maiores proporções na BHC de maneira a considerar o tempo de trânsito das águas e o amortecimento de cheias do APM Manso. Dessa forma será possível avaliar o nível de segurança que o reservatório garante à população, em especial ribeirinha, no que compete ao extravasamento da calha menor em situações críticas da bacia hidrográfica do rio Cuiabá.

\subsection{Objetivos}

Tendo em vista os problemas elucidados em relação às inundações do rio Cuiabá, a proposta deste trabalho é avaliar o efeito amortecedor do reservatório da usina hidrelétrica de Manso sobre as enchentes da BHC, no estado de Mato Grosso. O que se pretende é verificar em que grau o APM Manso pode influenciar no controle de cheias em benefício das cidades a jusante, em especial Rosário Oeste, Acorizal, Cuiabá e Várzea Grande.

Para tanto, o trânsito da onda de cheia efluente do reservatório será simulado hidraulicamente com a aplicação do modelo hidrodinâmico unidimensional CLiv, desenvolvido pela Fundação Centro Tecnológico de Hidráulica (FCTH), o qual foi disponibilizado gratuitamente para a realização desta pesquisa. A fim de representar a vazão 
de contribuição da área intermediária entre o reservatório e as cidades, vazões específicas fundamentadas em registros fluviométricos serão adicionadas à efluência da usina hidrelétrica.

Após a calibração e validação dessa ferramenta, três cenários principais serão analisados. Associados à capacidade de amortecimento do reservatório, os cenários examinados estão voltados à avaliação do comportamento do rio Cuiabá tanto em situações de cheias extremas já registradas antes e após a construção da UHE Manso - e assim comparar com os valores observados nas estações fluviométricas da $\mathrm{BHC}$ - quanto em cheias de projeto com períodos de retorno críticos afluentes ao APM Manso. 


\section{CHEIAS EM BACIAS HIDROGRÁFICAS}

Um dos fundamentos da legislação que institui a Política Nacional de Recursos Hídricos, Lei n. 9.433 de 1997 (BRASIL, 1997a), é a respeito da unidade territorial representada pela bacia hidrográfica para a implementação do gerenciamento de recursos hídricos. A importância voltada à bacia advém do fato de todos os processos hidrológicos atuarem nessa unidade independentemente do conceito de divisões políticas. Inseridos nesse cenário estão todos os processos físicos, sujeitos às condições topográficas e meteorológicas, por exemplo. Tais processos influenciam de maneira direta a disponibilidade dos recursos naturais. Em razão das distribuições desses recursos naturais, especialmente a água e solo, a população humana se difunde e opta pelos locais que irão habitar.

Em uma comunidade, de maneira geral, é observado que as regiões altas são mais valorizadas, e são ocupadas por pessoas de maior poder aquisitivo; enquanto os terrenos baixos, como planícies, tendem a ser ocupados pela população de menor renda, devido à sua desvalorização. Entre diversos outros fatores, o desinteresse por regiões de menor cota topográfica acontece em virtude da busca por conforto e segurança, visto que essas áreas são mais propensas a problemas de cheias, que por ora podem vir a se tornar inundação. Cabe esclarecer que as cheias são da natureza de quaisquer sistemas hídricos, normalmente sazonais e um tanto previsíveis; já a inundação é consequência do extravasamento da calha principal do rio durante a cheia.

O acúmulo de água nas regiões de planície pode causar ou não inundação em função da combinação de muitos fatores associados à bacia hidrográfica, como o seu formato, o tempo de concentração da água, o volume precipitado e o tipo de ocupação do solo. Alguns desses fatores, como o último, podem ser modificados em pouco tempo, inclusive sob a ação do homem, ao passo que outros somente se alteram em períodos de escalas geológicas. Desse modo, a partir de algumas atividades antropogênicas, regiões podem se tornar mais ou menos propensas à inundação. Por outro lado, como existem alguns aspectos sobre os quais o homem não possui qualquer influência, algumas bacias têm tendência natural para essas ocorrências, e isso deve ser interpretado como um efeito do sistema fluvial a ser admitido e respeitado. 


\subsection{Tipos de inundações}

As inundações se diferenciam por suas características, e costumam ser classificadas especialmente porque para cada uma delas as respostas devem ser distintas (SUDEC/MT; BRASIL, 2007):

- Inundações repentinas, bruscas ou enxurradas: São frequentes em terrenos de relevo acentuado e de vales profundos, como nas regiões serranas do sul (vale do Itajaí) e sudeste (interior fluminense) brasileiros. Não obrigatoriamente acontecem nos limites das calhas fluviais. $O$ fator preponderante sobre essas enxurradas é a concentração de grande quantidade de água em curto período em função especialmente da elevada declividade do terreno. Elas são provocadas por chuvas intensas, ou moderadas e por longo período, quando o solo esgota sua capacidade de infiltração. Como possuem elevada energia de transporte, as enxurradas podem carregar detritos e objetos de grande porte ao serem deparados pelo caminho, a ponto de adquirem grande poder destruidor.

- Inundações tipo alagamento: São águas acumuladas nas vias de transporte principalmente em função das más condições de drenagem pluvial. O fenômeno é associado às regiões de baixa declividade e à redução da infiltração natural nos solos urbanos, característica comum nas maiores cidades.

- Inundações lentas, ou de planície: São resultantes do aumento dos níveis de água de forma paulatina e razoavelmente previsível durante uma enchente. Eles se mantêm elevados durante algum tempo, e em seguida escoam gradualmente pela calha fluvial. Normalmente, essas inundações são cíclicas e nitidamente sazonais, sem grande capacidade de arraste. Algumas vezes essas cheias estão associadas a um período de retorno anual, como no Pantanal, ou maior que esse tempo, como na BHC em Cuiabá.

\subsection{Inundações como desastres naturais}

O International Strategy for Disaster Reduction (ISDR, 2005), vinculado às Nações Unidas, desenvolve estratégias para reduzir e combater as perdas com desastres ao redor do mundo. Ele categoriza essas ocorrências em: geofísicos (terremotos, tsunamis e vulcões), biológicos (epidemias e infestações de pestes) e hidrometeorológicos (inundações, deslizamentos, secas, entre outros). Em 2005, o ISDR realizou um levantamento sobre a quantidade e o tipo dos desastres naturais nos anos de 2004 e 2005 registrados ao redor do 
globo. A Figura 2 ilustra o resultado do estudo, onde pode ser visualizado que entre os onze conjuntos principais, as inundações (ou flood), estão destacadas em maior número. Evidentemente, não foram contabilizados os casos de alagamentos provocados por deficiências de drenagem urbana. Conforme já mencionado, as inundações têm origem nas peculiaridades da bacia hidrográfica, porém, em muitos casos, a presença do homem influencia na disposição dessas ocorrências.

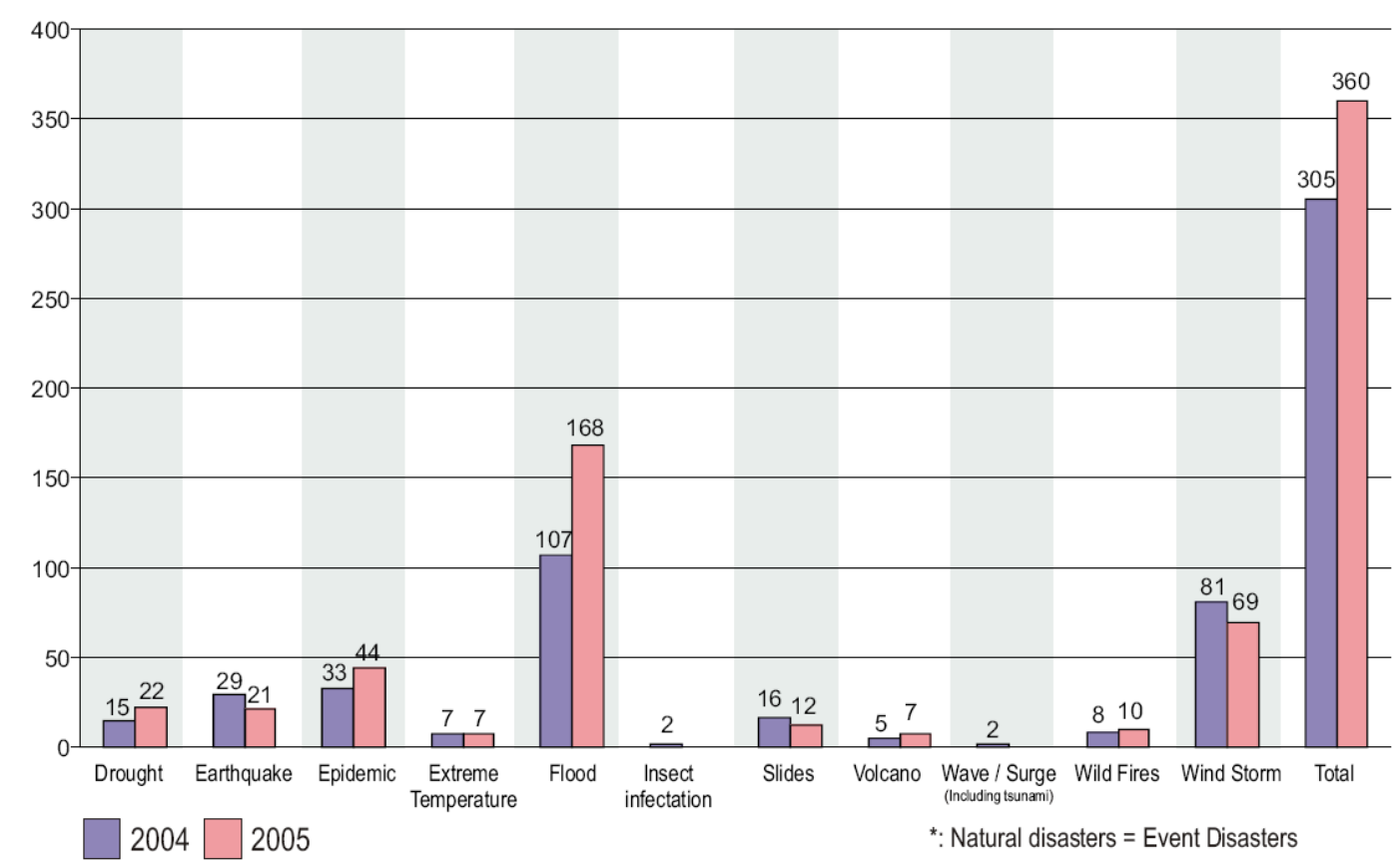

Figura 2 - Desastres naturais em 2004 e 2005 no mundo Fonte: ISDR (2005)

Os impactos das inundações nas comunidades são de diversas características, e envolvem prejuízos tanto de ordem material quanto social. Entre alguns, são citados a perda ou danificação de objetos pessoais e habitações, a possibilidade de haver processo de realocação provisória ou permanente dos desabrigados, a interrupção de serviços de saneamento, eletricidade ou de logística em geral para abastecimento público e o aumento da possibilidade do desencadeamento de outros problemas naturais, como erosões e deslizamentos (LOU, 2010; PEDROLLO e DE PAES, em fase de elaboração).

\subsection{Medidas de combate às inundações}

Existem muitas maneiras de se agir em favor da redução de impactos que as enchentes podem causar. Incluem-se entre elas as medidas não-estruturais, geralmente de cunho 
mitigador, e que envolve, por exemplo, a elaboração de mapas de áreas de risco, regulamentação do uso da terra, elaboração de planos de emergenciais, otimização da operação de reservatórios, entre outros. Enquanto que as medidas estruturais consistem em ações de ordem física, como construção de diques, escavação dos canais fluviais e de reservatórios de amortecimento. Este último é capaz de reter parte do volume de água, regulariza a vazão a jusante e reduz o pico de cheia, aumentando o tempo de base do hidrograma para a liberação paulatina do acumulado no reservatório (TUCCI, 1993; BRASIL, 2007).

Segundo Brasil (2007), a United Nations Disaster Relief Organization (UNDRO), também vinculada às Nações Unidas, se fundamentou em duas atividades para elaborar um modelo de abordagem para o enfrentamento de acidentes naturais: prevenção e preparação.

As atividades de prevenção estão relacionadas a estudos de natureza técnico-científica, na definição da magnitude de um desastre e no estabelecimento das medidas que possibilitem a proteção da população e de seus bens materiais. Tais atividades compreendem os estudos da fenomenologia dos processos, da análise de risco e a formulação de métodos, técnicas e ações de prevenção de desastres. Enquanto as atividades de preparação têm caráter logístico, auxiliando no enfrentamento de situações de emergência ligadas, principalmente, aos trabalhos de Defesa Civil. Nesta fase são indicadas quais populações devem ser evacuadas e protegidas quando localizadas em áreas de alto risco ou logo após a ocorrência do processo. Os programas de mitigação de desastres da UNDRO incluem uma seqüência de ações de prevenção e preparação: identificação dos riscos, análise dos riscos, medidas de prevenção, planejamento para situações de emergência, informações públicas e treinamento (BRASIL, 2007).

A atuação da Defesa Civil nas três esferas governamentais tem o objetivo de reduzir desastres e atenuar o seu impacto nas populações. A Política Nacional de Defesa Civil estabelece diretrizes, planos e programas prioritários para o desenvolvimento de ações de redução de desastres em todo o país, bem como a prestação de socorro e assistência às populações afetadas. Através do Sistema Nacional de Defesa Civil, a ela cabe:

- $\quad$ Promover ações de prevenção de desastres naturais, antropogênicos e mistos;

- Realizar estudos, avaliar e reduzir riscos de desastres;

- Atuar na iminência e em circunstâncias de desastres; e 
- Prevenir ou minimizar danos, socorrer e assistir populações afetadas, e restabelecer os cenários atingidos por desastres.

De maneira geral a Defesa Civil tem suas ações voltadas a prevenir desastres e, caso eles já tenham ocorrido, agir da melhor maneira para evitar demais prejuízos. Em abordagem a esse assunto, quatro fases principais serão discutidas: de caráter preventivo, de socorro, assistencial e recuperativo.

\subsubsection{Fase preventiva}

A fase preventiva é a de absoluta normalidade, e a qual órgãos governamentais responsáveis devem aproveitar para elaborar os planos preventivos e emergenciais (SHIRASHI, 2003), como a definição dos locais de abrigo para a população atingida e as áreas de risco de inundação. Durante essa fase é comum e apropriado o estabelecimento das ações estruturais e não-estruturais para combate às inundações na bacia hidrográfica. Em conjunto com outros órgãos e instituições, devem ser elaboradas políticas e normas a serem seguidas pela comunidade a respeito do que possa interferir nas condições de segurança.

No tocante às inundações, essa é a fase para instalação das réguas fluviométricas e estações hidrometeorológicas, elaboração de pesquisas sobre os sistemas hídricos, definição das planícies de inundação e faixas para ocupação humana. Tucci (1993) recomenda que essas faixas sejam determinadas em (i) zona de passagem de enchentes, (ii) zona com restrições e (iii) zona de baixo risco. Os tipos de ocupação devem ser restritos conforme o risco que cada zona está sujeita.

\subsubsection{Fase de socorro}

Com a ocorrência de um desastre, as ações seguintes devem ser de emergência para que haja busca e salvamento do maior número de atingidos possível. A eficiência do socorro à população está intensamente relacionada com o cumprimento da fase preventiva. Quando a circunstância exige, é declarada a situação de emergência ou ainda o estado de calamidade pública. Nessa condição, o administrador público adquire maiores liberdades para facilitar a tomada de decisões emergenciais sem as formalidades normalmente exigidas por lei, como 
para aquisição de materiais e contratação de serviços terceirizados. Além disso, regulamentado pelo Decreto n. 7.257 de 2010 (BRASIL, 2010b), o reconhecimento de situação de emergência e estado de calamidade pública permite ao ente público a transferência de recursos do governo federal para ações de socorro, assistência às vítimas, restabelecimento de serviços essenciais e reconstrução nas áreas atingidas por desastre.

\subsubsection{Fase assistencial}

No instante após o socorro devem ser realizados o atendimento e a acomodação das pessoas atingidas. A principal atividade nesta etapa é a triagem e o atendimento aos vitimados. Há o reagrupamento das famílias e a separação dos grupos de vítimas para o atendimento às demandas conforme as necessidades. O cadastro é de grande valia, não apenas para dar maior rendimento por ocasião da assistência, como para fins lógicos e estatísticos. Entre diversas outras ações, ocorrem nessa fase a identificação dos atingidos, instalação dos flagelados nos abrigos e acampamentos, assistência médica e psicossocial, fornecimento de vestimentas e a vigília das áreas atingidas para evitar saques (SHIRASHI, 2003).

\subsubsection{Fase recuperativa}

A recuperação da comunidade atingida acontece normalmente de maneira gradual, conforme a intensidade do dano. Para a eficiência dessa fase, vários planos devem ser atendidos, especialmente os direcionados ao restabelecimento em plenitude dos serviços públicos, da segurança comunitária, da economia e moral social (SHIRASHI, 2003). Devido à racionalidade do fato ocorrido e à compreensão dos riscos, essa é uma ótima fase para revisão da estrutura preventiva de segurança da comunidade e para execução das ações de forma que novos desastres sejam evitados.

\subsection{Estabelecimento dos níveis de segurança do rio Cuiabá}

Uma das medidas preventivas realizada pela Superintendência Estadual de Defesa Civil de Mato Grosso (SUDEC/MT) é a definição dos níveis de segurança de altura da lâmina de água dos corpos fluviais que banham as localidades com maiores riscos de inundação, entre eles o rio Cuiabá. Assim, é feito o monitoramento do nível de água e as escalas de risco podem ser mensuradas. Conforme o município, esses níveis podem ser de um a três: cota de alerta, cota de emergência e cota de calamidade. Shirashi (2003) discutiu essas considerações. 


\subsubsection{Cota de alerta}

O alerta é definido quando o evento atinge o limite entre a situação de normalidade e a iminência da anormalidade. A partir do nível de água equivalente ao de alerta, todo o corpo de funcionários da SUDEC/MT deve se reunir para tomar conhecimento e ficar em expectativa para possíveis ações. Outros órgãos e instituições governamentais, assim como a imprensa, podem ser contatados para auxiliar as comunidades frente ao risco potencial.

\subsubsection{Cota de emergência}

Em situação pior que o alerta, a emergência é definida quando as causas diversas possam exigir a declaração do estado de calamidade. Só se configura emergência quando os efeitos provocam considerável prejuízo, como elevado número de desabrigados, desabastecimento, interdição de vias de acesso importantes, epidemia generalizada, entre outros.

\subsubsection{Cota de calamidade}

Esse estado pode ser atingido em condições tais que o agravamento dos efeitos desastrosos tenham adquirido tamanha proporção que se tornou impossível superá-los através dos meios operacionais da situação de emergência, provavelmente já declarada. Isso pode ocorrer, também, quando as causas perduram e seus efeitos aumentam e afetam gravemente a comunidade, com privação total ou parcial de atendimento de suas necessidades básicas. 





\section{MODELOS MATEMÁTICOS EM RECURSOS HÍDRICOS}

Especialmente em virtude da necessidade de manutenção da qualidade e quantidade de água há grande demanda por melhoria na gestão dos recursos hídricos em todo o globo, e isso exige constante aprimoramento das técnicas de análise, operação, planejamento e tomada de decisão voltados a essa questão. Uma das mais importantes ferramentas para auxiliar no desenvolvimento de metodologias para lidar com esse problema é simulação matemática, que permite que um sistema seja representado matematicamente através de modelos computacionais.

De acordo com Azevedo, Porto e Zahed Filho (2002), a partir da década de 1960, os modelos de simulação matemática em recursos hídricos têm sido progressivamente aplicados em diversas áreas, como na quantificação dos processos hidráulicos do escoamento de água e do ciclo hidrológico, nos modelos ambientais e meteorológicos e na análise de qualidade de água. O modelo matemático é uma ferramenta que converte os dados conhecidos em informações sobre os problemas. Assim, ele fornece resposta de um sistema a um conjunto de informações de entrada, que incluem regras de decisão, permitindo que o executor examine as consequências de diversos cenários de um sistema existente ou hipotético.

Entre outros argumentos, Porto e Azevedo (2002) mencionam que "o custo de cometer erros ou realizar experiências com o sistema real é incomparavelmente maior do que o custo da exploração intensiva do modelo". Assim, grandes vantagens podem ser tiradas da aplicação de um modelo matemático em virtude da flexibilidade existente, que envolve, por exemplo, a simples alteração de uma informação e a análise das diversas respostas geradas com um custo significativamente menor que o valor da própria informação. Assim, um modelo hidráulico permite que sejam conhecidos os diversos comportamentos do escoamento fluvial em função de um número variável de elementos que nela atuam, como a variação de vazão a jusante, ou a alteração da calha fluvial. Esses elementos são as características dos fenômenos do ciclo hidrológico - como evapotranspiração, precipitação, infiltração no solo e escoamento fluvial ou subterrâneo - que recebem influência do relevo, clima, ocupação do solo, localização geográfica, entre outros. Essas características, quando adicionadas pelo usuário, podem ser denominadas de entradas; enquanto as saídas são os resultados gerados pelo modelo. 
Sobre esse assunto, Tucci (2005) ressalta que uma simulação perfeita é considerada impraticável, já que não se pode representar na íntegra todas as relações e processos existentes em um sistema tão complexo como uma bacia hidrográfica. Wendland (2003) afirma que as modelagens são uma aproximação dos fenômenos existentes na realidade de um sistema, havendo continuamente a possibilidade de incerteza.

O cuidado em desenvolver e utilizar modelos de modo que sejam o mais realístico possível deve ser contrabalanceado com outras importantes considerações, entre elas o compromisso com os cálculos, a acessibilidade dos dados a serem coletados para entrada no modelo, e o atendimento às exigências do usuário (Hunter et. al., 2007). Dentro de um contexto de relevância e confiabilidade, ao se formular o modelo matemático é objetivo representar a realidade física com maior fidelidade e praticidade possível em termos de gasto computacional e alimentação. A capacidade de gerar as informações hidráulicas exigidas em nível de detalhes e formatos apropriados dentro do conceito de otimização da relação entre o custo e o benefício deve ser considerada (ABBOT, 1979; FCTH, 2003; HUNTER et. al., 2007).

Obedecendo a esses preceitos, a Figura 3 ilustra o esquema básico de um modelo de simulação em que o conjunto Descrição do sistema, restrições e política de operação representa a parte lógica do algoritmo. Os dados controláveis e não controláveis são a sua alimentação, sendo estes os parâmetros fixos (por exemplo, informações topográficas) e aqueles, as variáveis (como as vazões em função do tempo). O julgamento do decisor sobre o resultado, ou saída, influenciará o retorno dos dados de entrada para que sejam feitas análises conforme os objetivos.

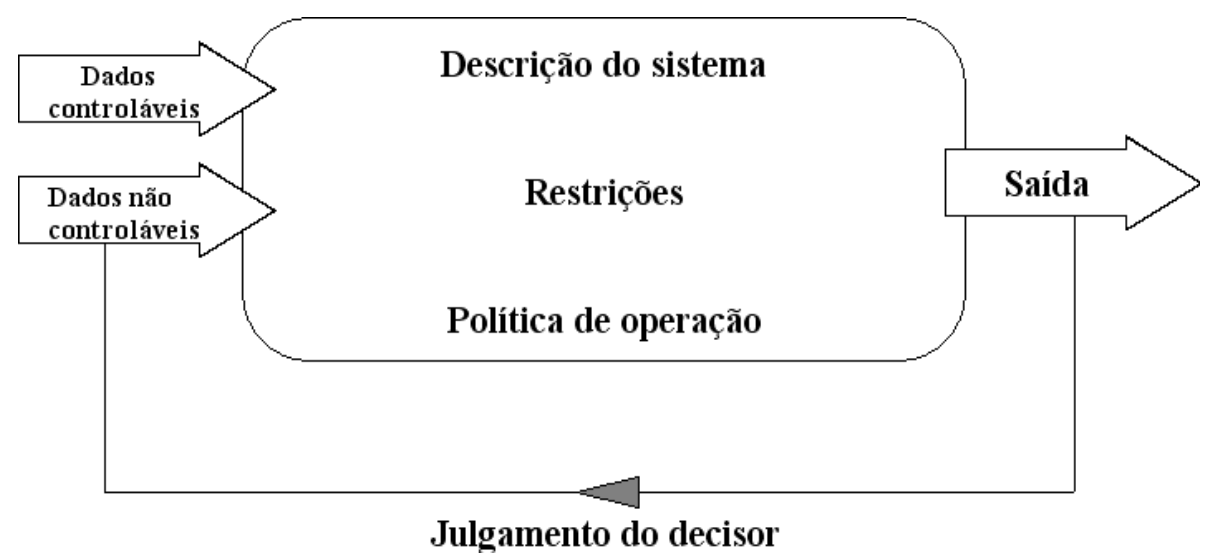

Figura 3 - Representação esquemática de um modelo de simulação Fonte: Azevedo, Porto e Zahed Filho (2002) 
Sucintamente, as principais razões para se realizar simulações em recursos hídricos são: auxiliar a compreensão do comportamento da bacia hidrográfica, prever consequências de alterações de um ou mais fatores envolvidos com o sistema hídrico, auxiliar a tomada de decisões sobre intervenções diversas, gerar informações adicionais ou complementares (PORTO e AZEVEDO, 2002). Como exemplo prático de aplicação do modelo podem ser citados a resposta da bacia frente ao aumento da demanda de água de um manancial por determinada população, ou à mudança da cobertura vegetal de uma região, ou ainda à ocorrência de eventos incomuns de precipitação. Então, em posse dos resultados gerados pela simulação, analisam-se as medidas cabíveis a serem tomadas a fim de que se possam tomar decisões ou precauções as mais corretas possíveis. Portanto, a modelagem hídrica pode ser interpretada como uma ferramenta que possibilita a aplicação de medidas apropriadas de maneira que se previnam ou reduzam os problemas que porventura possam ocorrer no sistema em função de alterações naturais ou antropogênicas.

O processo de utilização de um modelo matemático envolve, em geral, três fases: (i) ajuste (ou estimativa) dos parâmetros, (ii) verificação e (iii) previsão (TUCCI, 2005). O ajuste dos parâmetros é a fase inicial da simulação. Nessa etapa, os parâmetros devem ser determinados para a faixa de variação que contemple as situações da previsão a partir de séries históricas, dados amostrais e características físicas do sistema. A verificação é a simulação do modelo com os parâmetros estimados, e onde se examina por comparação a validade dos parâmetros adotados. A correlação entre as duas etapas anteriores permite realizar a previsão, que é a simulação do sistema pelo modelo com parâmetros ajustados para a quantificação de sua resposta a diferentes entradas, inclusive para situações desconhecidas.

\subsection{Classificação dos modelos matemáticos em recursos hídricos}

Existem diversos aspectos sobre os quais se classificam os modelos de gerenciamento dos recursos hídricos. Algumas das principais maneiras de dispô-los são em função da forma de representação dos dados no intervalo de tempo, da existência ou não de relações espaciais, do tipo de variáveis utilizadas, do tipo de relações entre as variáveis e da existência ou não de dependência temporal. O Quadro 1, elaborado com base nos textos de Rennó e Soares (2000) e Tucci (2005), apresenta as principais classificações dos modelos, bem como o critério para tal disposição e a descrição do tipo do modelo. 
Quadro 1 - Classificações e descrições de modelos conforme os seus critérios

\begin{tabular}{|c|c|c|}
\hline Critério & Classificação & Descrição \\
\hline \multirow[t]{2}{*}{$\begin{array}{l}\text { Representação dos dados } \\
\text { no intervalo de tempo }\end{array}$} & Contínuo & $\begin{array}{l}\text { Registros efetuados continuamente ao longo do } \\
\text { tempo }\end{array}$ \\
\hline & Discreto & $\begin{array}{l}\text { Registros efetuados em intervalos de tempo com } \\
\text { frequiências pré-determinadas }\end{array}$ \\
\hline \multirow[t]{2}{*}{$\begin{array}{l}\text { Relações espaciais dos } \\
\text { dados }\end{array}$} & Concentrado & $\begin{array}{l}\text { Não leva em consideração a variabilidade espacial, } \\
\text { sintetizando os processos hidrológicos em blocos }\end{array}$ \\
\hline & Distribuído & $\begin{array}{l}\text { Variáveis e parâmetros dependem do espaço e do } \\
\text { tempo simultaneamente }\end{array}$ \\
\hline \multirow[t]{2}{*}{$\begin{array}{l}\text { Característica das } \\
\text { variáveis }\end{array}$} & Estocástico & $\begin{array}{l}\text { Ideia de aleatoriedade no resultado final para as } \\
\text { mesmas entradas }\end{array}$ \\
\hline & Determinístico & $\begin{array}{l}\text { As entradas resultarão sempre nos mesmos dados } \\
\text { de saída }\end{array}$ \\
\hline \multirow[t]{2}{*}{$\begin{array}{l}\text { Relações entre as } \\
\text { variáveis }\end{array}$} & Empírico & $\begin{array}{l}\text { Relações baseadas em observações, sem ligação } \\
\text { com os processos físicos envolvidos no sistema }\end{array}$ \\
\hline & Conceitual & $\begin{array}{l}\text { Relações baseadas nos processos físicos durante a } \\
\text { elaboração das funções do modelo }\end{array}$ \\
\hline \multirow[t]{2}{*}{$\begin{array}{l}\text { Existência ou não de } \\
\text { dependência temporal }\end{array}$} & Estático & $\begin{array}{l}\text { Dados de entrada produzem uma saída oriunda da } \\
\text { resolução da equação do modelo em um único } \\
\text { passo }\end{array}$ \\
\hline & Dinâmico & $\begin{array}{l}\text { Resultado de uma iteração é utilizado como entrada } \\
\text { para uma próxima iteração }\end{array}$ \\
\hline
\end{tabular}

Maidment (1993), Vertessy et al. (1993), Rennó e Soares (2000) e Tucci (2005) discorrem sobre essas classificações.

São ditos sistemas contínuos quando os fenômenos são de fato contínuos ao longo do tempo, sendo isto o que ocorre naturalmente. A variação das cotas linimétricas de um rio sendo representada intermitentemente ao longo do dia é um exemplo de representação contínua. Porém, para serem trabalhados, normalmente são utilizados registros lidos em intervalos de tempo. Em estações fluviométricas as cotas linimétricas geralmente são registradas duas vezes por dia. Isto caracteriza um sistema discreto de representação de dados. Este artifício torna o trabalho de aquisição e manipulação mais simples, porém tende a perder 
em exatidão dos resultados. A maioria dos sistemas hidrológicos é do tipo contínuo e representado por modelo discreto.

Os modelos podem também ser classificados como concentrados (ou pontuais, ou ainda agregados) ou distribuídos. Em modelos concentrados não se considera a variabilidade espacial ou temporal, e é levado em conta que todas as variáveis de entrada e saída sejam representativas de toda a área estudada. Os modelos distribuídos consideram a variabilidade espacial, ou temporal, nas diversas variáveis e parâmetros do modelo. Na prática, determinada discretização do espaço é feita durante a modelagem, não havendo modelos perfeitamente distribuídos. Assim, cada elemento é tratado como um ponto que representa homogeneamente toda a sua área de abrangência. A qualidade dos modelos distribuídos é avaliada pela capacidade em representar melhor as variáveis espacial e temporal do sistema, sujeitas às condições de entrada. Nesse contexto, o trabalho conjunto entre modelos distribuídos e as ferramentas de geoprocessamento e de modelos digitais de terreno tendem a aprimorar as representações das diferentes partes da bacia hidrográfica estudada.

Outra classificação é quanto à aleatoriedade dos resultados de saída. Para as mesmas condições de entrada, um modelo é estocástico se pelo menos uma das variáveis envolvidas traz resultados de comportamento caracterizado pela lei da probabilidade. Se na elaboração de um modelo cada entrada resultar em uma saída específica, e os conceitos probabilísticos não existirem, este será denominado determinístico.

Quanto às relações entre as variáveis, os modelos podem ser empíricos, se utilizam relações baseadas em observações, ajustando-os a dados calculados, através de funções que não têm nenhuma relação com os processos físicos envolvidos. Esses modelos são práticos, porém mais limitados, visto que são específicos à região para a qual as relações foram estimadas. Os modelos conceituais têm funções baseadas nos processos físicos da bacia hidrográfica. De forma geral, são mais complexos que os empíricos, pois procuram descrever todos os processos envolvidos no fenômeno estudado, algumas vezes necessitando incluir modelos detalhados e multivariados, que geralmente requerem bom conjunto de informações e parametrização cuidadosa antes da execução; em compensação, expandem os limites da modelagem. Devido à complexidade, considera-se que mesmo as funções conceituais têm certo grau de empirismo em suas formulações. Os principais entraves na aplicação de um modelo conceitual estão relacionados à variabilidade espacial dos processos e à dificuldade de estimar os parâmetros. 
Por fim, em relação à existência ou não de dependência temporal entre os dados, os modelos podem ser estáticos, quando a partir de um conjunto de dados de entrada a resolução das equações do modelo é atingida em um único passo. Enquanto os modelos dinâmicos utilizam o resultado de uma iteração como entrada para a próxima iteração.

\subsection{Escolha do modelo matemático em recursos hídricos}

Grande número de modelos matemáticos foi desenvolvido com vista à melhor adaptação do objeto estudado com as ferramentas e tecnologias existentes. Tucci (2005) explica que o fator preponderante de haver diversos modelos são as limitações da heterogeneidade física das bacias e dos processos nela envolvidos. Assim, todos os modelos têm vantagens e desvantagens. Eles se diferenciam basicamente nos dados de entrada viáveis, ou necessários, nas prioridades para representação da bacia e nos dados de saída que se pretende obter (WENDLAND, 2003). Normalmente, em função dessas questões são determinados os tipos de modelos a serem adotados.

A definição do modelo matemático a ser utilizado em estudos hidrológicos é orientada por itens como (TUCCI, 2005):

- Objetivo para o qual ele será aplicado;

- Características da bacia hidrográfica;

- Dados disponíveis;

- Familiaridade com o modelo.

No tocante ao objetivo da modelagem, é recomendável avaliar a prioridade do tipo de resultado que se queira obter, pois geralmente modelos com alta precisão requerem maiores detalhamentos, e, portanto, maiores custos. A área de estudo pode ser inapropriada para alguns tipos de modelo, se este for constituído por processos hidrológicos que seu código computacional não adota como prioridade, tendendo ao erro. Da mesma maneira, os dados disponíveis devem atender as exigências do modelo, já que as séries históricas podem não ser compatíveis com o requerido para a entrada de informações, como a discretização temporal representativa de dados de descarga fluvial. Em todo caso, de nada adianta que todas essas condições sejam favoráveis se o modelo não for do gosto, ou ainda acessível, ao operador. Por esse motivo, é praxe considerar que o melhor modelo matemático é aquele que o usuário tenha intimidade com seu manuseio. 
Para orientar a escolha de um modelo, Porto e Azevedo (2002) indicam alguns critérios:

- $\quad$ Precisão - representação da realidade de forma suficientemente próxima para permitir a tomada de decisões com base em seus resultados;

- $\quad$ Simplicidade - pela maior facilidade para compreensão, é desejável que tenha número reduzido de parâmetros e variáveis, além de uma estrutura que represente somente a essência do sistema;

- Robustez - garante que o modelo represente bem a realidade com o menor número possível de parâmetros sem prejuízo caso seja necessário adicionar outras variáveis totalmente diferentes que as utilizadas na calibração;

- $\quad$ Transparência - a interação modelo-usuário é normalmente feita pela alteração sistemática de dados de entrada e parâmetros, mas por permitir que sejam realizadas experiências diversas, a possibilidade de introduzir alterações no código garante maior intimidade com o modelo.

- Adequação - a boa adequação às diversas necessidades do usuário é um complemento para que a transparência seja boa. É preferível que a interface seja clara e autoexplicativa, sem ambiguidades sobre significado e validade dos resultados, assim como sobre as possibilidades de alimentação do modelo.

\subsection{Simulação hidrodinâmica}

O escoamento de um fluido é definido como não permanente e gradualmente variado quando os seus parâmetros hidráulicos, em geral velocidade e nível de água, se modificam progressivamente ao longo da corrente em função do tempo e do espaço (PORTO, 2006). Essa característica é a situação mais encontrada nos canais fluviais.

Tendo em conta que o movimento de fluidos é determinado por três princípios físicos fundamentais - conservação de massa, de quantidade de movimento e de energia - os fenômenos hidráulicos do escoamento podem ser satisfatoriamente representados com a modelação matemática (SOTO, 2004; SILVA, 2006). Desse modo, é possível obter respostas fidedignas a respeito das características hidráulicas do movimento das águas em um canal, 
contanto que em posse de algumas informações hidráulicas e geométricas do sistema para alimentação do modelo.

Em razão das forças preponderantes que atuam no movimento das águas, são quatro os modelos de escoamento: (i) de armazenamento, (ii) de onda cinemática, (iii) de difusão e (iv) hidrodinâmico. Com base em Tucci (2005) e LOU (2010), eles são explicados na Tabela 2.

Tabela 2 - Classificações dos modelos de escoamento

\begin{tabular}{|c|c|c|}
\hline Modelo de escoamento & Forças atuantes & Utilização \\
\hline Hidrodinâmico & $\begin{array}{l}\text { É o mais completo, pois aborda todas } \\
\text { as forças envolvidas na equação da } \\
\text { quantidade de movimento - inércia, } \\
\text { pressão, gravidade e atrito. }\end{array}$ & $\begin{array}{l}\text { Garantem maior precisão e melhor } \\
\text { representação física do escoamento } \\
\text { mesmo em situações complexas, além } \\
\text { de permitirem simular modificações do } \\
\text { sistema estudado. }\end{array}$ \\
\hline De difusão & $\begin{array}{l}\text { São desprezados os termos de inércia } \\
\text { da equação da quantidade de } \\
\text { movimento. }\end{array}$ & $\begin{array}{l}\text { Pode ser usado em rios que sofrem } \\
\text { efeitos de jusante, quando a velocidade } \\
\text { não tem gradientes significativos. }\end{array}$ \\
\hline De onda cinemática & $\begin{array}{l}\text { São desprezados os termos de inércia e } \\
\text { pressão da equação da quantidade de } \\
\text { movimento. }\end{array}$ & $\begin{array}{l}\text { Por interpretar que a declividade da } \\
\text { linha de fundo é igual à da linha de } \\
\text { atrito, diversos critérios devem ser } \\
\text { analisados para utilização desse } \\
\text { modelo, como os relacionados à } \\
\text { celeridade e período da onda. }\end{array}$ \\
\hline De armazenamento & $\begin{array}{l}\text { Utiliza uma variação da equação da } \\
\text { continuidade e uma relação entre } \\
\text { armazenamento e a vazão de entrada e } \\
\text { saída do trecho. }\end{array}$ & $\begin{array}{l}\text { Devido à facilidade e ao pequeno } \\
\text { volume de dados necessários, são } \\
\text { muito utilizados para casos simples, em } \\
\text { especial quando o efeito preponderante } \\
\text { é o armazenamento de água, e quando } \\
\text { não há efeito de jusante sobre o } \\
\text { escoamento. }\end{array}$ \\
\hline
\end{tabular}

Seguindo os critérios de classificação dos modelos matemáticos, conforme apresentado no Quadro 1 da página 22, os modelos hidrodinâmicos são discretos no que diz respeito à representação dos dados no intervalo de tempo, além de possuírem relação espacial dos dados de maneira distribuída. As suas variáveis têm característica determinística e a relação entre elas é de caráter conceitual. Quanto à dependência temporal, é dinâmica, pois durante a operação do modelo, o resultado de uma iteração é utilizado como entrada para uma próxima iteração.

De acordo com Tucci (2005) os modelos hidrodinâmicos têm características principais de sintetizar vazões em rios e rede de canais fluviais ao longo do seu percurso. Dentro da 
hidráulica fluvial seus usos são bastante amplos, e podem envolver desde a simulação de alterações do sistema até estudos sobre efeitos da translação da onda de cheia. Contudo, de acordo com Porto (2006), a maior precisão na descrição do escoamento se faz à custa de maior dificuldade numérica de resolução das equações diferenciais e da necessidade de maior quantidade de dados, se comparado aos demais modelos de escoamento.

As equações que permitem resolver a modelagem hidrodinâmica compõem o que é conhecido como Equações de Saint Venant. Elas são a equação da continuidade (ou da conservação de massas), conforme (Eq. 1) e da quantidade de movimento (Eq. 2).

$$
\begin{aligned}
& \frac{\partial A}{\partial t}+\frac{\partial Q}{\partial x}=q \\
& \frac{\partial Q}{\partial t}+\frac{\partial}{\partial x}\left(\frac{Q^{2}}{A}\right)+g A \frac{\partial y}{\partial x}=g A \widehat{S}_{0}-S_{f}
\end{aligned}
$$

Sendo:

$\mathrm{Q}=\operatorname{vazão}\left[\mathrm{m}^{3} \cdot \mathrm{s}^{-1}\right]$

$\mathrm{A}=$ área da seção molhada $\left[\mathrm{m}^{2}\right]$;

$\mathrm{x}=$ distância no sentido longitudinal $[\mathrm{m}]$;

$\mathrm{t}=$ tempo $[\mathrm{s}]$;

$\mathrm{q}$ = vazão por unidade de largura de contribuição lateral $\left[\left(\mathrm{m}^{3} \cdot \mathrm{s}^{-1}\right) \cdot \mathrm{m}^{-1}\right]$;

$\mathrm{g}=$ aceleração da gravidade $\left[\mathrm{m} . \mathrm{s}^{-2}\right]$;

y = lâmina de água $[\mathrm{m}]$;

$\mathrm{S}_{0}=$ declividade do canal $\left[\mathrm{m} . \mathrm{m}^{-1}\right]$

$\mathrm{S}_{\mathrm{f}}=$ declividade da linha de atrito $\left[\mathrm{m} \cdot \mathrm{m}^{-1}\right]$.

As equações de Saint Venant podem ser expressas de diversos modos em função da preferência ou necessidade, e aplicadas como apresentado, ou seja, em função da vazão e da profundidade; ou, entre outras maneiras, de forma a relacionar a velocidade com a 
profundidade, se a variação da largura com o comprimento for desprezada. A lei da continuidade relaciona o volume de uma dada célula computacional ao fluxo de entrada e de saída durante um intervalo de tempo. Em relação à equação completa da quantidade de movimento, desenvolvida por Saint Venant, as quatro forças mencionadas são as relativas à inércia $\left[\frac{\partial Q}{\partial t}+\frac{\partial}{\partial x}\left(\frac{Q^{2}}{A}\right)\right]$, à pressão $\left[g \cdot A \cdot \frac{\partial y}{\partial x}\right]$, à gravidade [g.A.S $\left.{ }_{0}\right]$ e ao atrito $\left[\mathrm{g} . \mathrm{A} . \mathrm{S}_{\mathrm{f}}\right]$.

Apesar do contínuo desenvolvimento computacional, estão em uso muitas técnicas e programas baseados em equações simplificadas. Segundo Lou (2010), a razão para isso varia desde a inércia de modeladores, que continuam a usar métodos e programas desenvolvidos há muito tempo, até a necessidade de modelos simplificados em certas situações, como na estimativa de previsão de uma cheia em tempo real, quando é importante que o modelo seja executado durante a cheia. Fread (1992) pontua outras razões para as simplificações na representação matemática, como a disponibilidade de dados, a capacidade do modelo em produzir informações seguras para responder as questões inquiridas, a característica do sistema a ser modelado e a disponibilidade de recursos computacionais, tempo e serviço humanos. Algumas hipóteses simplificadoras normalmente aceitas para a dedução das equações de Saint Venant são (PORTO, 2006):

- $\quad$ Fluido incompressível;

- Variação gradual das seções transversais;

- $\quad$ Escoamento unidimensional, assim a velocidade média é representativa da variação espacial na seção, e o sentido predominante do escoamento é longitudinal;

- Distribuição hidrostática de pressão é na vertical, isso despreza eventuais efeitos de componentes de aceleração vertical;

- $\quad$ Ausência de singularidades como contrações na calha, pilares de ponte, soleiras de fundo, entre outros;

- Declividade da linha de energia pode ser calculada por uma equação estabelecida para o regime permanente e uniforme, como as equações de Manning ou Chézy.

Além do modelo hidrodinâmico unidimensional - que são aplicados em situações em que o escoamento segue prioritariamente a direção longitudinal do curso de água - os 
modelos bi e tridimensionais também são largamente empregados em simulações hidráulicas. O modelo hidrodinâmico bidimensional é aplicado aos corpos de água que se caracterizam pela predominância dos processos horizontais sobre os verticais, como as planícies de inundação e estuários. Os modelos de células (ou pseudo-bidimensionais) são outra abordagem para simular escoamento em regiões com planícies e se baseiam no conceito de células interconectadas que formam uma rede bidimensional no plano horizontal para representar a planície: as células são consideradas áreas de armazenamento, com localização, forma e conexões determinadas conforme a morfologia e topografia locais. Os modelos hidrodinâmicos tridimensionais são também aplicados a sistemas de águas rasas, entretanto são mais comumente aplicados em situações cuja componente vertical do escoamento passa a ser importante para os processos de mistura, estratificação e transporte de constituintes (Paz, 2010).

Apesar de a composição do fluxo em um canal ser tridimensional (3D), a complexidade do tratamento numérico torna esta consideração válida somente para problemas com escalas pequenas em termos de extensão fluvial, preferencialmente menor que $1 \mathrm{~km}$ (HUNTER et. al., 2007). Este mesmo autor explica que entre os fatores limitantes para a simulação 3D são citadas a inviabilidade computacional e a imprecisão na representação da superfície fluvial.

Por questões de pragmatismo e favorecimento à ciência, os modelos hidrodinâmicos mais empregados são as simplificações do escoamento para a uni (1D) e bidimensionalidade (2D). De fato, cada modelo possui vantagens e desvantagens. Em termos de tempo de construção, os modelos 2D são normalmente mais rápidos, especialmente quando são disponíveis modelos digitais de elevação confiáveis. Entretanto, modelos 1D requerem menor tempo para processamento, o que representa vantagem particular em situações de previsão de cheias. De maneira geral, os modelos 1D costumam ter menores custos, além de serem mais facilmente encontrados no mercado. Conforme Verwey (2005), a precisão dos modelos 1D pode ser maior se o escoamento do corpo de água permanecer nos limites do canal principal, porém se a componente planície fluvial entrar em questão, o 2D pode ser mais apropriado. Samuels (1990) destaca outras três inconveniências dos modelos 1D: subjetividade da locação e orientação do corte transversal do rio, incapacidade de simular a difusão lateral da onda de cheia e o fato de a discretização da topografia ser interpretada como cortes transversais e não como superfície. 


\subsection{Métodos numéricos para os cálculos de escoamento hidrodinâmico}

A resolução dos cálculos dos modelos matemáticos é feita por meio dos métodos numéricos. Particularmente na aplicação de modelos em recursos hídricos, os métodos numéricos são empregados de modo a computar as variáveis do sistema fluvial, geralmente tempo e vazão, em diferentes pontos da grade computacional. Os métodos numéricos permitem a discretização do rio através de seções, mas podem produzir erros numéricos e tendenciosidade na escolha das seções. Os mais comuns para resolução das equações de Saint Venant são o método das diferenças finitas (MDF), método dos elementos finitos (MEF) e método dos volumes finitos (MVF). Desde as primeiras aplicações das equações de escoamento superficial, os modelos de inundação têm sido normalmente resolvidos por meio do MDF, pois em geral apresentam maior robustez. Nele, as equações diferenciais parciais (que possuem ao menos duas variáveis independentes) são convertidas em um equivalente das equações das diferenças finitas, e a partir de então são solucionadas pelos esquemas computacionais. Durante a resolução dos métodos numéricos, o termo derivado do tempo pode ser discretizado em diversos modos, seja usando os esquemas explícitos ou os implícitos. Esses esquemas são empregados para aproximar a vazão e o nível de água na grade computacional. A consequência de escolher um ou outro esquema implica na estabilidade do modelo numérico e na complexidade do algoritmo para resolver as equações (ABBOT, 1979; CUNGE et. al. 1980; TUCCI, 2005; PORTO, 2006; HUNTER et. al., 2007; PRAMANIK et. al., 2009).

No esquema explícito de discretização temporal, as variáveis dependentes são computadas em cada elemento da grade numérica em função das condições resultantes do tempo anterior. As soluções explícitas normalmente são mais simples e de fácil formulação. A desvantagem dos esquemas explícitos é que eles são estáveis apenas sob determinadas condições. $\mathrm{O}$ intervalo de tempo do modelo deve ser escolhido de modo que seja pequeno o suficiente (escala de segundos) para atender a condição de Courant, ou outras análogas, e assim prevenir instabilidades no desenvolvimento da solução numérica (CUNGE et. al., 1980; HUNTER et. al. 2007). A condição de estabilidade de Courant se baseia na relação entre a discretização espacial adotado e o maior valor absoluto previsto para a velocidade da onda de cheia. Para que essa condição seja satisfeita, a discretização temporal deve ser igual ou menor à mencionada relação (PORTO, 2006). Ainda quanto aos esquemas explícitos, Tucci (2005) afirma que "quando as variáveis da equação diferencial mudam rapidamente no tempo, o uso de intervalo pequeno de cálculo é uma necessidade e essa limitação não é tão importante". Tal 
característica leva a um intervalo de tempo de cálculo demasiado reduzido se comparado ao fenômeno físico da inundação, que normalmente tem escala de horas, dias ou até semanas.

Por outro lado, no esquema implícito as condições de escoamento em um determinado elemento no instante de tempo atual são dependentes tanto das condições do instante anterior quanto das condições atuais nos demais elementos. Assim, é formado um conjunto de equações para serem resolvidas, e são determinados o nível e a vazão em todos os elementos da grade computacional simultaneamente (PAZ, 2010). Os esquemas implícitos agregam todas as células dentro do domínio da solução, o que permite que o comportamento da vazão seja representado por meio da entrada no modelo de grades. Em compensação, a comunicação entre a distante localização das células no domínio da solução resulta no custo computacional e no aumento da complexidade do código. De qualquer maneira, as limitações dos esquemas implícitos são menores. Entre as principais vantagens levantadas por Hunter et. al. (2007) são destacados a garantia de estabilidade incondicional à solução e a possibilidade de escolha de maiores intervalos de tempo (escala horária), o que torna o esquema mais compatível com a evolução de um evento fluvial. De acordo com Tucci (2005), esses fatores contribuem para que o esquema implícito seja o mais utilizado entre os programas de uso comercial ou público.

A maioria dos programas utilizados em simulação de escoamentos não permanentes vale-se de diferentes variantes de esquemas implícitos. Entre eles, o mais comum para a análise de escoamento não permanente com superfície livre é o Esquema de Pressman, recomendado para simulação de regimes subcríticos ou fluviais (TUCCI, 2005; PORTO, 2006; FCTH, 2003). Suas características de estabilidade e precisão permitem a utilização em aplicações diversas, desde canais artificiais até cursos de água naturais de grandes dimensões. Todavia, o método apresenta severas limitações para a simulação de escoamento em regime supercrítico, como em locais onde há grandes estrangulamentos de seção, ou em condições de fundo com intensas variações de cota. Para essas situações, é sugerida a utilização do método explícito de MacCormack. Este esquema é destinado à simulação de escoamentos com ondas rápidas e condições supercríticas, e se fundamenta na aplicação de diferenças finitas de segunda ordem de acuracidade (FCTH, 2003). 


\subsection{Alimentação dos modelos hidrodrodinâmicos}

A aplicação do modelo hidrodinâmico em um curso de água requer as especificações dos parâmetros dos modelos e das condições de contorno que definam adequadamente as características do escoamento. Normalmente os dados exigidos são de três tipos: (i) informações topográficas para construção da grade computacional do modelo; (ii) estimativa da resistência do escoamento; (iii) dados quantitativos para prover as condições de contorno de entrada e de saída ao sistema, como hidrogramas, linigramas ou curvas-chave.

\subsubsection{Informações topográficas}

A identificação de informações topográficas apropriadas para o uso nos modelos hidrodinâmicos 1D, como a escolha das seções topobatimétricas ao longo dos cursos de água em estudo, frequentemente é definida por critérios subjetivos. Entende-se por seção topobatimétrica o acoplamento das informações obtidas pelo levantamento topométrico (referente à parte seca da seção transversal) com os dados do levantamento batimétrico (parte molhada da seção). Intuitivamente, quanto maior o número de seções, melhor a precisão da simulação, o que em grande parte é verdadeiro, já que devem representar a topobatimetria em estudo. Entretanto, o número extremado de seções topobatimétricas não necessariamente majora a precisão dos resultados, pelo contrário, pode até reduzi-la, pois resulta em grande quantidade de cálculos, e assim aumenta a propagação dos erros numéricos. A obtenção de informações topográficas que alimentam uma modelagem hidráulica, quer por medições de campo ou via sensoriamento remoto, normalmente exige custos, fator este considerado limitante, em especial para países em desenvolvimento (SAMUELS, 1990; FCTH, 2003; SILVA, 2006).

A escolha dos pontos para estabelecimento das seções topobatimétricas visando à modelagem hidráulica deve ser realizada com base em uma mescla de bom senso, experiência e análise teórica. Sobre esta definição, Samuels (1990) propôs algumas regras, as quais foram posteriormente seguidas à risca em pesquisa com dois rios europeus e também admitidas por Castellarin et. al. (2009). Entre esses fatores são citados aspectos óbvios, como a determinação da topobatimetria em:

- $\quad$ Limites externos do sistema hídrico para que sejam utilizadas na adoção das condições de contorno externas; 
- Pontos especiais dentro do sistema, e que poderão servir de condição de contorno interna, como estrangulamento do rio ou confluências;

- $\quad$ Locais onde há estações fluviométricas;

Entre outras considerações, os autores recomendam localizações das seções:

- A cada 10 a 20 vezes a largura da superfície do canal fluvial, como estimativa inicial. Esta relação é considerada um consenso comum entre os modeladores;

- Distância máxima de $20 \%$ da relação [y/S $\mathrm{S}_{0}$, sendo "y" o nível de água, e " $\mathrm{S}_{0}$ " a declividade do canal principal. Esta recomendação é sugerida com base nos princípios de possíveis efeitos de remanso de escoamentos subcríticos. Samuels (1990) alerta que acima deste comprimento, o remanso de montante decai para menos que $10 \%$ do valor original;

- Distância máxima equivalente a [C/30], sendo " $C$ " o comprimento escalar da onda de cheia, e definido como equivalente a $70 \%$ da relação $\left[\mathrm{y} / \mathrm{S}_{0}\right]$;

- Quando aplicados em códigos computacionais com resoluções via esquemas implícitos de Pressman, a proporção entre a área molhada de seções topobatimétricas sucessivas deve ser entre $2 / 3$ e $3 / 2$ uma da outra, para garantir estabilidade e para que os erros numéricos sejam pequenos.

Essas proposições são as consideradas desejáveis para a definição ótima de seções topobatimétricas na simulação hidráulica, e o não atendimento pode resultar em perda da qualidade esperada para uma modelagem. Muitas vezes essas recomendações não podem ser atendidas por causa de fatores limitantes como inacessibilidade aos pontos almejados, falta de recursos financeiros e tecnológicos. Assim, cabe ao modelador se aproximar desses fatores a fim de tentar representar ao máximo o comportamento do sistema.

Até a década de 1980, os dados topográficos eram muito trabalhosos para serem obtidos, pois as metodologias eram extremamente dependentes de pesquisas de campo ou de aerofotogrametria. Nos últimos anos, novas técnicas possibilitadas pelo sensoriamento remoto têm facilitado a maneira de solucionar problemas para provisão de informações topográficas (HUNTER et. al., 2007). 
Algumas alternativas para estudo em áreas com pouca disponibilidade de dados são a extração perfis de seção do rio para estabelecimento dos parâmetros geométricos da calha fluvial através de metodologia baseada em modelos digitais de elevação provenientes de sistemas imageadores a laser teletransportados, como o Lidar - Light Detection and Rangig ou o InSAR - Interferometric Synthetic Aperture Radar - ambos para áreas de pequenas proporções. Ou, para trabalhos em bacias de maiores escalas e com grandes planícies de inundação podem ser usados os dados do SRTM DEM - Shuttle Radar Topographic Mission - aplicado ao modelo digital de elevação, que são dados de elevação da superfície da Terra com resolução espacial de $0,0083333^{\circ}$ (cerca de $90 \mathrm{~m}$ ) e abrangência global, disponíveis gratuitamente na rede mundial de computadores por meio do sítio eletrônico do CGIAR-CSI ${ }^{2}$ (PRAMANIK et. al., 2009; PAZ, 2010).

\subsubsection{Resistência do escoamento}

Há uma relação de dependência da resistência do fluxo de água com diversos fatores, entre eles a rugosidade da superfície do leito, vegetação, formas da calha fluvial e a quantidade de sedimentos em suspensão (CHOW, 1959). Para a boa representação, os modelos hidráulicos requerem a especificação dessa resistência do fluxo de água através de um coeficiente com frequência sintetizado na expressão rugosidade.

De acordo com Hunter et. al. (2007), em teoria, esses valores podem ser especificados individualmente para cada célula computacional. Apesar de serem estimados com elevado grau de precisão, tem sido muito difícil demonstrar que esses parâmetros sejam capazes de fornecer previsões exatas na realização de um modelo único. Isso acontece porque os coeficientes de rugosidade estão incumbidos de representar diferentes fontes de perda de energia, cujo tratamento dentro de um modelo em particular varia com a dimensionalidade do código e o processo de representação de decisões. O autor alerta que os parâmetros calibrados devem ser reconhecidos como sendo valores efetivos que não são capazes de reproduzir, mas de representar, as heterogeneidades do cálculo, e que não devem ter uma interpretação física fora do modelo dentro do qual eles foram ajustados.

Uma maneira tradicional para calibração da rugosidade se dá a partir da identificação de valores empíricos até que o modelo seja capaz de calcular resultados semelhantes aos

\footnotetext{
${ }^{2}$ CGIAR-CSI - Consultative Group for International Agriculture Research - Consortium for Spatial Information. Disponível em: <http://srtm.csi.cgiar.org>. Acesso em 9 mar 2011.
} 
dados observados disponíveis. A comparação entre os valores calculados pelo modelo e os observados permite reajustar o coeficiente de rugosidade até que ambos sejam o mais idêntico possível. Para a adoção dos primeiros valores empíricos, Chow (1959) e Porto (2006) sugerem padrões de coeficientes de rugosidade em função de diversos tipos de canais fluviais.

Outros métodos para ajuste da rugosidade são mencionados por Hunter et. al. (2007). Há modelos conceituais que contêm parâmetros eficazes que estão relacionados com as descrições dos processos hidráulicos agregados, e que não podem, em geral, ser determinados a partir das características físicas do canal em questão. Já em alguns modelos físicos mais consistentes, os parâmetros do modelo devem, a princípio, ser avaliados a partir dos dados de campo. A este respeito, análises complementares de dados por sensoriamento remoto, e que podem informar, por exemplo, características sobre a granulometria e a vegetação da região do canal fluvial, demonstram potencial para prover medições da rugosidade.

\subsubsection{Condições de fluxo}

O cálculo para modelagem hidrodinâmica exige a determinação de condições de contorno externas e, quando necessário, internas. Tucci (2005) elucida que as condições de contorno externas são adotadas em função do regime a ser simulado, de modo que para os regimes fluviais - situações em que as forças gravitacionais da massa de água são superiores às de inércia - especificam-se uma condição a montante e outra a jusante, já que os efeitos se propagam segundo as linhas características. Enquanto que para os regimes torrenciais quando as forças de inércia prevalecem sobre as gravitacionais - são especificadas duas condições a montante. A respeito das condições de contorno internas ao sistema, estas são aplicadas se houver variações bruscas na morfologia do canal fluvial interior ao sistema, seja ele natural ou artificial. Citam-se como exemplos as confluências, as bacias de armazenamento e as barragens.

As definições das condições de contorno são geralmente obtidas pelos registros do comportamento natural do rio, via estações hidrometeorológicas, ou em função da operação de obras hidráulicas a montante do trecho, como a efluência de uma usina hidrelétrica com reservatório. Esses valores são capazes de fornecer estimativas razoáveis do comportamento da translação da onda de cheia em determinado instante. 
Hunter et. al. (2007) atenta para o fato de que as medições fluviométricas são geralmente carregadas no modelo através de séries históricas de vazões ou níveis de água que estão sujeitas a falhas conforme o aumento da profundidade, velocidade e estabilidade da margem. O autor ainda lembra que os hidrogramas são provenientes da medição linimétrica aplicados à curva-chave, e isso tende, também, à imprecisão.

Outro aspecto que pode ser afetado pela imprecisão é a discretização temporal das medições fluviométricas. Quase sempre as leituras de níveis de água são realizadas poucas vezes por dia (usualmente de uma a três) e discretizar esses valores para intervalos menores, como o horário, pode ocultar picos da cheia.

A esse respeito, Tan et. al. (2007) publicaram um trabalho sobre a desagregação de vazões diárias a partir de dados observados ou modelados por simulações hidrológicas, desde que estejam disponíveis informações de vazões discretizadas em escalas reduzidas, preferencialmente horárias, ao menos por curto período, e que estas cubram diversos eventos de cheia. Eles se fundamentaram no artifício empírico de desagregação de vazões diárias para semidiárias baseado em um índice de inclinação de ascensão e de declive do hidrograma da cheia. Os autores explicaram que as leituras de vazões discretizadas em períodos inferiores a um dia permite referenciar as informações do hidrograma de inundação em relação ao denominado índice de inclinação de subida e descida de vazões no hidrograma para realizar projeções para outras situações durante uma discretização.

É provável que essa abordagem seja mais importante para bacias hidrográficas cujos eventos únicos podem ser decisivos para o pico da cheia, onde há consideráveis variações da vazão e reduzido tempo de concentração. Devido à necessidade de observações horárias pelo menos por curto período, e de definições de alguns critérios de independência para seleção dos eventos de referência, como os intervalos temporais de cheia por intervalos bem definidos, a execução dessa metodologia para a discretização horária do hidrograma se torna impraticável em muitas circunstâncias.

Em relação à segurança na adoção da discretização igualmente distribuída de vazões diárias para horárias, Silva e Tucci (1998) realizaram uma pesquisa em 59 pequenas e médias bacias hidrográficas no sul e sudeste brasileiros. Foi estudada a razão entre a vazão de pico real - normalmente não registrada em estações fluviométricas - e a vazão diária - definida geralmente como a maior observada entre duas leituras por dia ( $7 \mathrm{~h}$ e $17 \mathrm{~h}$ ). Ao comparar as características físicas e hidrológicas das bacias, ficou constatado que, de modo geral, as de maior área (escala de alguns milhares de $\mathrm{km}^{2}$ ) tendem à razão de número 1 ; ou seja, pouca 
diferença entre as vazões de pico e as vazões diárias. Outras situações que tendem à menor variabilidade entre a vazão de pico e a vazão diária são em casos cujo tempo de concentração seja superior a 48h; e, ainda, cujos eventos de ocorrência nessas bacias tenham elevados períodos de retorno, caracterizando cheias de maiores proporções.

\subsection{Incertezas dos modelos em recursos hídricos}

Diversos fatores estão envolvidos na modelagem em recursos hídricos desde o desenvolvimento do código, passando pelo carregamento de informações, ajuste de parâmetros, obtenção dos resultados e sua interpretação. Em cada um desses processos existe a possibilidade de erro na representação real do sistema, o que decorre na sua incerteza. $\mathrm{O}$ termo incerteza é conceituado por Walker et. al. (2003) como qualquer desvio do valor ideal não alcançável frente ao determinismo caracterizado pelo modelo matemático.

A noção da magnitude e do tipo das incertezas que influenciam uma simulação é de significativa relevância para a interpretação fiel dos resultados, os quais, em posse deles, resoluções importantes costumam ser tomadas (WARMINK et. al. 2011). Assim, o conhecimento das incertezas pode ser utilizado para minimizar possíveis erros da modelagem.

Segundo Lou (2010), as principais incertezas envolvidas com a simulação estão relacionadas às (i) limitações da estrutura dos modelos para representar o sistema; (ii) erros de aquisição das variáveis de entrada; e (iii) ajustes dos parâmetros. Os motivos gerais das incertezas são as simplificações quase sempre adotadas, a complexidade dos processos naturais e a falta de conhecimento dos parâmetros (TUCCI, 2005).

Recentemente, algumas pesquisas têm estudado os fatores e influências das incertezas como um aspecto isolado, a ponto de em determinados modelos matemáticos eles ganharem o status de dado de entrada ou de um parâmetro específico que a represente (Warmink et. al., 2011).

A procura pela melhor representação do sistema hídrico tem valorizado a identificação e quantificação das incertezas nos últimos anos. Com foco nessa questão, Warmink et. al. (2011) entrevistaram 17 modeladores, selecionados entre 42 especialistas em simulação de recursos hídricos. Duas situações distintas foram consideradas: (i) o caso da simulação de nível de água de projeto e (ii) a simulação do efeito hidráulico causado pela mudança do leito do canal. A principal diferença entre elas é a descarga fluvial: enquanto na primeira situação a 
informação de entrada caracteriza uma onda de cheia, na segunda a vazão é constante. Na simulação de níveis de água foi concluído que a vazão de entrada de montante e a rugosidade do canal principal exercem maior influência nas incertezas. Quanto à hipótese da mudança da margem do rio, os fatores que contribuem com a maior parte das incertezas são a batimetria da planície de inundação, a representação da perda de carga e a discretização topográfica.

\subsection{Modelo hidrodinâmico para condutos livres (CLiv)}

O modelo hidrodinâmico CLiv compõe um pacote de seis modelos matemáticos voltados à simulação em recursos hídricos desenvolvido pela FCTH - Fundação Centro Tecnológico de Hidráulica. No CLiv, o escoamento em canais é definido como um problema unidimensional. Sua aplicação é específica para simulações em condutos livres, razão pela qual possui esse nome. (FCTH, 2003).

O modelo é dotado de uma interface gráfica para entrada de dados e visualização de resultados. Para a simulação de modelos transitórios ele conta com o esquema implícito de Pressmann e para simulação de ondas rápidas e condições supercríticas, com o esquema explícito de MacCormack. Sua aplicação possibilita obter dados de linha de água em canais naturais ou artificiais, em regime permanente ou em regime de transitórios hidráulicos, como a propagação de ondas de cheia, contanto que de superfície livre, por meio das equações completas de Saint Venant. Com o CLiv é possível, ainda, determinar áreas inundáveis e gerar automaticamente seções transversais a partir da topografia.

Alguns trabalhos têm aplicado o CLiv para modelagem hidrodinâmica. Certas vezes esses projetos são acoplados com outros modelos em recursos hídricos, em geral hidrológicos, com a função da representação global da bacia hidrográfica. Assim, com foco principal em aprimorar um sistema de suporte a tomada de decisões em gerenciamento de cheias, Silva (2006) reuniu diversas ferramentas voltadas à previsão de chuvas, cálculo de vazões incrementais através de modelos hidrológicos e definição de níveis de água por meio de análises hidrodinâmicas, este último com a utilização do modelo matemático CLiv. A área de estudo foi a bacia hidrográfica do Ribeira de Iguape, que ocupa parte dos estados de São Paulo e Paraná, na região hidrográfica do Atlântico Sudeste.

Getirana (2005) utilizou o modelo CLiv para simular o escoamento hidrodinâmico em um canal na bacia hidrográfica do rio Paraíba do Sul, ao norte do estado fluminense. A modelagem hidrodinâmica foi parte de um trabalho cujo objetivo principal foi propor uma 
ferramenta baseada na programação linear para obtenção de propostas viáveis para negociação de soluções para conflitos pelo uso da água em região de elevada demanda para a agricultura. A função do CLiv neste trabalho foi identificar vazões toleráveis sem extravasamento da calha fluvial, situação que causaria prejuízo aos agricultores ribeirinhos.

De acordo com ONO (2008), o consórcio Engecorps/Harza (2000) ${ }^{3}$ utilizou o CLiv na realização de modelagens hidrodinâmica e de esquema operacional para os estudos básicos referentes ao projeto de transposição de águas do rio São Francisco para o nordeste setentrional.

Brandão e Barros (2007) aplicaram modelos hidrodinâmico, hidrológico e digital de terreno para identificar manchas de inundação em cheias com diversos períodos de retorno na bacia hidrográfica do córrego do Bananal, na zona urbana de São Paulo. Pela elevada declividade e processos intensivos de urbanização, a bacia está propensa a inundações em diversas localidades. Os resultados do trabalho serviram de base para formular propostas de melhorias para a bacia em questão nas áreas de controle de cheias e para o ordenamento do uso e ocupação do solo urbano. Este trabalho é parte de um projeto maior, sob coordenação de Barros (2002), denominado Gerenciamento integrado de bacias hidrográficas em áreas urbanas, na bacia hidrográfica do rio Cabuçu de Baixo, cujo córrego do Bananal é afluente. $\mathrm{O}$ projeto envolveu modelos de qualidade da água, hidrológico, hidrodinâmico, bem como levantamentos sedimentológicos e de dinâmica de ocupação urbana da bacia com foco principal ao desenvolvimento de um sistema de suporte a tomada de decisões. O modelo CLiv foi aplicado em todos os processos relacionados à modelagem hidrodinâmica. Integrante da mesma pesquisa, o trabalho desenvolvido por ONO (2008) também abordou questões relacionadas ao sistema de suporte a tomada de decisões nessa bacia.

\subsection{Calibração de modelos}

A calibração dos modelos matemáticos consiste na determinação dos parâmetros relativos ao sistema de modo a melhor representá-lo. É uma das etapas mais delicadas do processo de modelagem, e pode ser realizada de maneira automática ou manual. A calibração automática é efetuada a partir da aplicação de um algoritmo de otimização computacional a

\footnotetext{
${ }^{3}$ ENGECORPS/HARZA. (2000). Projeto de transposição de águas do rio São Francisco para o Nordeste setentrional. Relatório R12. Engecorps/Harza. São Paulo. 2000. 289p.
} 
um espaço de busca pré-determinado. Sobre esse assunto, Nascimento, Reis Jr. e Martins (2009) alertam que a determinação da função objetivo para a calibração pode ser de considerável dificuldade, já que a interação entre os parâmetros pode causar a formação de grandes regiões de indiferenças na superfície de resposta. Os autores recomendam, portanto, a utilização de funções multiobjetivo. Apesar disso, entre as desvantagens de se executar a calibração automática citam-se a não aquisição de sensibilidade do usuário para com os parâmetros, caso seja necessário avaliar sua coerência com o sistema real. Já a calibração manual pode ser demorada e extenuante, pois, além de exigir certa experiência do operador para atribuição dos valores, é realizada através de tentativa e erro.

Sobre a adoção dos parâmetros, Refsgaard (2001) comenta que em algumas situações a boa combinação nos padrões de resultados calculados e observados na aplicação de um modelo não significa que a bacia está sendo realisticamente simulada. Segundo o autor, é possível que apesar de os hidrogramas resultantes no processo de calibração serem semelhantes, o valor dos parâmetros seja tal que não representa a realidade física ou hidrológica da bacia em análise.

A calibração dos parâmetros do modelo é realizada de forma a comparar os valores calculados e observados até uma aproximação considerada aceitável para a modelagem. Essa comparação pode ser feita por diversas maneiras, o que inclui desde a aplicação de métodos estatísticos que confrontem os dois valores, ou pelo julgamento visual dos resultados em forma de gráficos. Algumas funções-objetivo normalmente utilizadas para avaliação da qualidade das calibrações serão apresentadas a seguir (CUDERLIK e SIMONOVIC, 2004; TUCCI, 2005; SCHARDONG et. al., 2009).

(i) EPVP - Erro porcentual da vazão de pico - consiste na comparação de picos entre os hidrogramas observados nas estações fluviométricas e os calculados pelo modelo matemático. Por se tratar de um índice relativo ao erro, quanto menor o seu valor, melhor a calibração. A função se baseia na (Eq. 3).

$$
\text { EPVP }=100 x \frac{\mid \text { Qmáx obs - Qmáx calc } \mid}{\text { Qmáx obs }}
$$


Sendo:

EPVP = Erro porcentual da vazão de pico [\%];

Qmáx obs = Vazão máxima observada $\left[\mathrm{m}^{3} \cdot \mathrm{s}^{-1}\right]$;

Qmáx calc = Vazão máxima calculada $\left[\mathrm{m}^{3} \cdot \mathrm{s}^{-1}\right]$.

(ii) EQRM - Erro quadrático relativo médio - sua resolução tende a priorizar os valores máximos do hidrograma. É ideal, portanto, para análise da qualidade de calibração de modelagens de cheias. Assim como a função anterior, quanto menor o EQRM, melhor a aderência, especialmente nos máximos. A (Eq. 4) representa esse parâmetro de calibração.

$$
\mathrm{EQRM}=100 \times \frac{\sum\left(1-\text { Qobs }_{\mathrm{t}} / \mathrm{Qcalc}_{\mathrm{t}}\right)^{2}}{\mathrm{n}^{\mathrm{o}} \text { série _ hist }}
$$

Sendo:

$\mathrm{EQRM}=$ Erro quadrático relativo médio (\%);

Qobs $_{\mathrm{t}}=$ Vazão observada no tempo " $\mathrm{t}$ " $\left[\mathrm{m}^{3} . \mathrm{s}^{-1}\right]$;

Qcalc $_{\mathrm{t}}=$ Vazão calculada no tempo "t $"\left[\mathrm{~m}^{3} \cdot \mathrm{s}^{-1}\right]$;

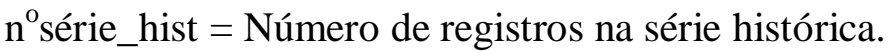

(iii) NS - Coeficiente de eficiência Nash-Sutcliffe - avalia a aderência das curvas calculadas e observadas com certa sensibilidade aos valores máximos. Seu valor se limita entre zero (quando não há qualquer semelhança entre as curvas) e 1 (quando os valores calculados são idênticos aos observados). Sua função-objetivo é representada pela (Eq. 5).

$$
\mathrm{NS}=1-\frac{\sum\left(\mathrm{Qobs}_{\mathrm{t}}-\mathrm{Qcalc}_{\mathrm{t}}\right)^{2}}{\sum\left(\mathrm{Qobs}_{\mathrm{t}}-\mathrm{Qmobs}_{\mathrm{t}}\right)^{2}}
$$

Sendo:

NS = Coeficiente de eficiência de Nash-Sutcliffe;

Qmobs $_{\mathrm{t}}=$ Vazão média observada no tempo " $\mathrm{t}$ " $\left[\mathrm{m}^{3} \cdot \mathrm{s}^{-1}\right]$. 
Diversas outras funções-objetivo são utilizadas na calibração dos parâmetros de um modelo matemático. Sua aplicação varia em razão da finalidade da modelagem. Assim, Cuderlik e Simonovic (2004) e Schardong et. al. (2009) ainda fazem referência a:

- $\quad$ SDR - Soma quadrática das diferenças - compara os desvios quadráticos entre a vazão observada e a calculada a cada intervalo de tempo. Esta função-objetivo enfatiza aos maiores valores;

- $\quad$ SEQMP - Soma dos erros quadráticos médios com pesos - semelhante à SDR, também considera o quadrado das diferenças entre vazão observada e calculada. A diferença é que a cada intervalo de tempo é atribuído um peso proporcional à magnitude da vazão calculada. Assim, as vazões maiores que a vazão média observada recebem peso maior que 1 , e as menores que a média, peso menor que 1 ;

- $\quad$ SEA - Soma dos erros absolutos - compara a vazão observada e a calculada a cada intervalo de tempo dando pesos iguais aos erros;

- $\quad$ EPV - Erro em porcentagem do volume - considera apenas o volume total e não leva em conta a magnitude e o tempo da vazão de pico.

\subsection{Amortecimento de reservatórios}

Um reservatório facilita sobremaneira o exercício de um dos fundamentos da legislação brasileira dos recursos hídricos (BRASIL, 1997a), que é a múltipla finalidade dos usos da água. Entre as muitas funções, ele pode ser responsável pela regularização de vazão em um rio e, portanto, pelo amortecimento de cheias na bacia hidrográfica. O mecanismo é simples: quando a onda de cheia de um canal fluvial transita pelo reservatório, este retém parte da vazão afluente em espaço a ela reservado, denominado volume de espera. Assim, enquanto o volume de espera não for preenchido, a defluência pode permanecer menor que a afluência, e o reservatório está apto a amortecer cheias.

A capacidade de atenuação de uma cheia é proporcional à dimensão do volume de espera. Porto et. al. (2007) comentam sobre a importância de o reservatório não estar cheio para suportar volume tal que o hidrograma de entrada possa ser parcialmente retido no período de chuvas. Dessa maneira, é essencial que haja o gerenciamento do reservatório de forma apropriada para que no início da época das cheias o nível de água esteja baixo o suficiente para esse controle. 
A estimativa de amortecimento de água proporcionado por um modelo de armazenamento considera a linha do nível de água do reservatório perfeitamente horizontal. Além disso, o modelo só é eficaz em locais com grande profundidade e baixa velocidade, pois as características do sistema fluvial devem ser tais que os termos dinâmicos do escoamento possam ser desprezados. Somente nessas condições o conceito do modelo passa a se basear no escoamento de armazenamento, conforme elucidado na Tabela 2 - Classificações dos modelos de escoamento, da página 26. Se a linha do nível de água do reservatório tiver inclinação o suficiente para não poder receber a aproximação de linha horizontal, o modelo de armazenamento não poderá ser utilizado, e outros métodos, como modelos hidrodinâmicos, deverão ser procurados (TUCCI, 2005).

Além do estudo sobre amortecimento de cheia proporcionado por um reservatório, os modelos de armazenamento são aplicados para diversas outras pesquisas hidrológicas, sempre nas condições mencionadas. Eles permitem análises como o dimensionamento do volume de espera, definição das regras de abertura e fechamento de comportas e determinação do hidrograma afluente a um reservatório (BARROS; ZAMBON e PORTO, 2009).

Diversas são as maneiras de calcular o amortecimento de cheias em reservatórios. A prática mais disseminada é pelo método de $P u l s^{4}$, publicado pela primeira vez em 1928, o qual passou por ligeira variação em 1958 e foi denominado método modificado de Puls ${ }^{5}$ (HERNANDEZ, 2007).

Para os cálculos de amortecimento de cheias são exigidas algumas informações fundamentais do sistema investigado, como (i) a curva cota-volume do reservatório, (ii) o hidrograma afluente e (iii) equações de descarga dos órgãos de extravasão da barragem. Vale lembrar que algumas vezes o reservatório possui saída de água por meio de vertedouro sem comportas; outras vezes os reservatórios são dotados de comportas, que devem obedecer à sua regra de operação. As informações acerca desses dispositivos permitirão conhecer a vazão efluente em cada intervalo. O procedimento de cálculo pelo método de Puls será explanado com base nos textos de Hernandez (2007), Barros, Zambon e Porto (2009) e Brandão (2010).

O princípio do escoamento de água em reservatórios se baseia na lei da continuidade. Sua equação significa que a variação do volume armazenado no reservatório em dado

\footnotetext{
${ }^{4}$ PULS, L. G. (1928). Flood Regulation of the Tennessee River. House Document. N. ${ }^{\circ} 185$, 70th Congress, st Session, U.S. Government Printing Office, Washington, D.C. pt.2, appendix B.

${ }^{5}$ BUTLER, S.S. (1957). Engineering Hydrology, Prentice-Hall,N.J.
} 
intervalo de tempo equivale à quantidade total de água afluente menos a quantidade efluente a esse reservatório no mesmo intervalo de tempo. Além da interpretação tomada na (Eq. 1), na página 27, a expressão matemática da equação da continuidade pode ser representada como na (Eq. 6).

$$
\mathrm{QE}_{\mathrm{t}}-\mathrm{QS}_{\mathrm{t}}=\frac{\mathrm{V}_{\mathrm{t}}}{\Delta \mathrm{t}}
$$

Sendo:

$\mathrm{QE}_{\mathrm{t}}=$ Vazão de entrada no reservatório no tempo “ $\mathrm{t}$ " $\left[\mathrm{m}^{3} \cdot \mathrm{s}^{-1}\right]$;

$\mathrm{QS}_{\mathrm{t}}=$ Vazão de saída do reservatório no tempo " $\mathrm{t}$ " $\left[\mathrm{m}^{3} \cdot \mathrm{s}^{-1}\right]$;

$\Delta \mathrm{t}=$ Intervalo de tempo, cuja unidade varia em função da discretização temporal;

$\mathrm{V}_{\mathrm{t}} / \Delta \mathrm{t}=$ Volume de água armazenado no reservatório no intervalo de tempo " $\Delta t$ " $\left[\mathrm{m}^{3}\right]$.

No passo seguinte, deve haver a discretização desta última equação em intervalos de tempo iguais. É fundamental que esses intervalos sejam suficientemente pequenos para que os picos possam ser bem representados, já que serão adotados valores médios de vazão entre os períodos, e assim, a variação da vazão entre um e outro intervalo de tempo será considerada linear. A discretização temporal da equação da continuidade é apresentada na (Eq. 7).

$$
\frac{\mathrm{QE}_{\mathrm{t}}+\mathrm{QE}_{\mathrm{t}+\Delta \mathrm{t}}}{2} \cdot \Delta \mathrm{t}-\frac{\mathrm{QS}_{\mathrm{t}}+\mathrm{QS}_{\mathrm{t}+\Delta \mathrm{t}}}{2} \cdot \Delta \mathrm{t}=\mathrm{V}_{\mathrm{t}+\Delta \mathrm{t}}-\mathrm{V}_{\mathrm{t}}
$$

Os termos da (Eq. 7) podem ser rearranjados para separar as variáveis conhecidas (à direita) das desconhecidas (à esquerda). Dessa organização é concebida a (Eq. 8).

$$
\mathrm{V}_{\mathrm{t}+\Delta \mathrm{t}}+\frac{\mathrm{QS}_{\mathrm{t}+\Delta \mathrm{t}}}{2} \cdot \Delta \mathrm{t}=\frac{\mathrm{QE}_{\mathrm{t}}+\mathrm{QE}_{\mathrm{t}+\Delta \mathrm{t}}}{2} \cdot \Delta \mathrm{t}-\frac{\mathrm{QS}_{\mathrm{t}}}{2} \cdot \Delta \mathrm{t}+\mathrm{V}_{\mathrm{t}}
$$

Eq. 8

Com o intervalo de tempo $\Delta t$ pré-determinado, são sabidas a vazão de entrada $\mathrm{QE}_{\mathrm{t}} \mathrm{e}$ $\mathrm{QE}_{\mathrm{t}+\Delta \mathrm{t}}$ (hidrograma afluente), a vazão de saída $\mathrm{QS}_{\mathrm{t}}$ (obtido a partir da regra operacional de saída de água) e o volume armazenado Vt (pela curva cota-volume). No entanto, duas 
incógnitas relativas ao instante posterior permanecem: o volume armazenado $\mathrm{V}_{\mathrm{t}+\Delta \mathrm{t}} \mathrm{e}$ a vazão de saída do reservatório $\mathrm{QS}_{\mathrm{t}+\Delta \mathrm{t}}$.

O problema de duas incógnitas em uma equação é resolvido com a adição de outra função matemática, determinada pela regra de operação da descarga do vertedouro, que correlaciona o nível de água do reservatório com a sua vazão de saída. Apenas por questão de exemplo, se for analisado o reservatório com saída de água unicamente por vertedouro retangular de soleira livre, sem comportas nem canal de fuga, a (Eq. 9) deverá ser utilizada.

$$
\mathrm{QS}_{\mathrm{t}}=\text { C.L.H } \mathrm{H}^{1,5}
$$

Sendo:

$\mathrm{C}=$ Coeficiente de descarga;

$\mathrm{L}=$ Largura do vertedor $[\mathrm{m}]$

$\mathrm{H}=$ Carga equivalente ao nível de água sobre a crista do vertedor [m].

O procedimento de cálculo de amortecimento de cheia em reservatório requer um processo iterativo. Para o início da resolução, um nível de água inicial deve ser arbitrado para posterior comparação com as vazões de entrada e saída do intervalo de tempo anterior. Quando este valor não é conhecido, pode ser adotado o nível de água médio operacional do reservatório. O cálculo segue iterativamente até serem computados todos os intervalos do hidrograma afluente. O roteiro sugerido por Brandão (2010) é:

1. Calcular o volume médio de entrada de água no intervalo de tempo $\Delta \mathrm{t}: \mathrm{VE}=$ $\left\{\left[\left(\mathrm{QE}_{1}+\mathrm{QE}_{2}\right) / 2\right] \cdot \Delta \mathrm{t}\right\} / 10^{6}$ - tempo em segundos e volume em milhões de $\mathrm{m}^{3}$;

2. Arbitrar o valor inicial para a variação do nível de água $(\Delta \mathrm{H})$ relativo ao volume de água acumulado no intervalo $\Delta \mathrm{t}$;

3. Estimar o nível de água para a extravasão do primeiro instante: $\mathrm{H} 2=\mathrm{H} 1+\Delta \mathrm{H}$. No decorrer do procedimento, $\mathrm{H} 1$ equivale ao $\mathrm{H} 2$ definido no intervalo anterior; 
4. Calcular a vazão de saída do instante seguinte, conforme a regra de descarga do vertedor: $\mathrm{QS}_{2}=$ C.L. $\mathrm{H}_{2}{ }^{1,5}$ (para vertedor retangular de soleira livre);

5. Calcular o volume médio equivalente à saída de água (VS) no período de tempo $\Delta \mathrm{t}$ : VS $=\left\{\left[\left(\mathrm{QS}_{1}+\mathrm{QS}_{2}\right) / 2\right] . \Delta \mathrm{t}\right\} / 10^{6}$. No decorrer do procedimento, o valor de $\mathrm{QS}_{1}$ será igual ao $\mathrm{QS}_{2}$ definido no $\Delta \mathrm{t}$ anterior. Tempo em segundos e volume em milhões de $\mathrm{m}^{3}$;

6. Calcular o volume correspondente à diferença entre a entrada e a saída de água no reservatório no intervalo $\Delta \mathrm{t}: \Delta \mathrm{V}=\mathrm{VE}$ - VS;

7. Calcular a diferença do nível de água $\left(\Delta \mathrm{H}^{*}\right)$ que equivalha à diferença do volume $\Delta \mathrm{V}$, conforme a curva cota-volume do reservatório;

8. Comparar $\Delta \mathrm{H}^{*}$ e $\Delta \mathrm{H}$. Se o módulo das diferenças for menor que um erro prédeterminado, o cálculo é finalizado; senão, retornar ao terceiro passo e adotar a igualdade $\Delta \mathrm{H}=\Delta \mathrm{H}^{*}$.

Como já comentado, para o cálculo da vazão efluente ao reservatório, o dispositivo de saída deve ser considerado. Ao mencionar a equação da vazão pelo vertedouro de soleira livre (Eq. 9), a situação de ausência de comportas foi adotada. Os sistemas de descarte de água em reservatórios com comportas possuem características individuais, e por isso não há uma função geral para todos os vertedouros. A operação das comportas infere na sua abertura total ou parcial conforme as efluências desejadas, portanto, várias equações podem ser necessárias.

A Figura 4 consiste em um esquema da regra operacional de um dispositivo de saída de água de um reservatório dotado de comportas. Normalmente, porcentagens de abertura das comportas são pré-definidas em função das cotas atingidas pelos níveis de água (eixo das ordenadas). Essa combinação, por sua vez, resulta em certa vazão vertida (eixo das abscissas). Em verdade, para melhor aplicação nos cálculos de amortecimento, essas curvas podem ser definidas em forma de equações. 


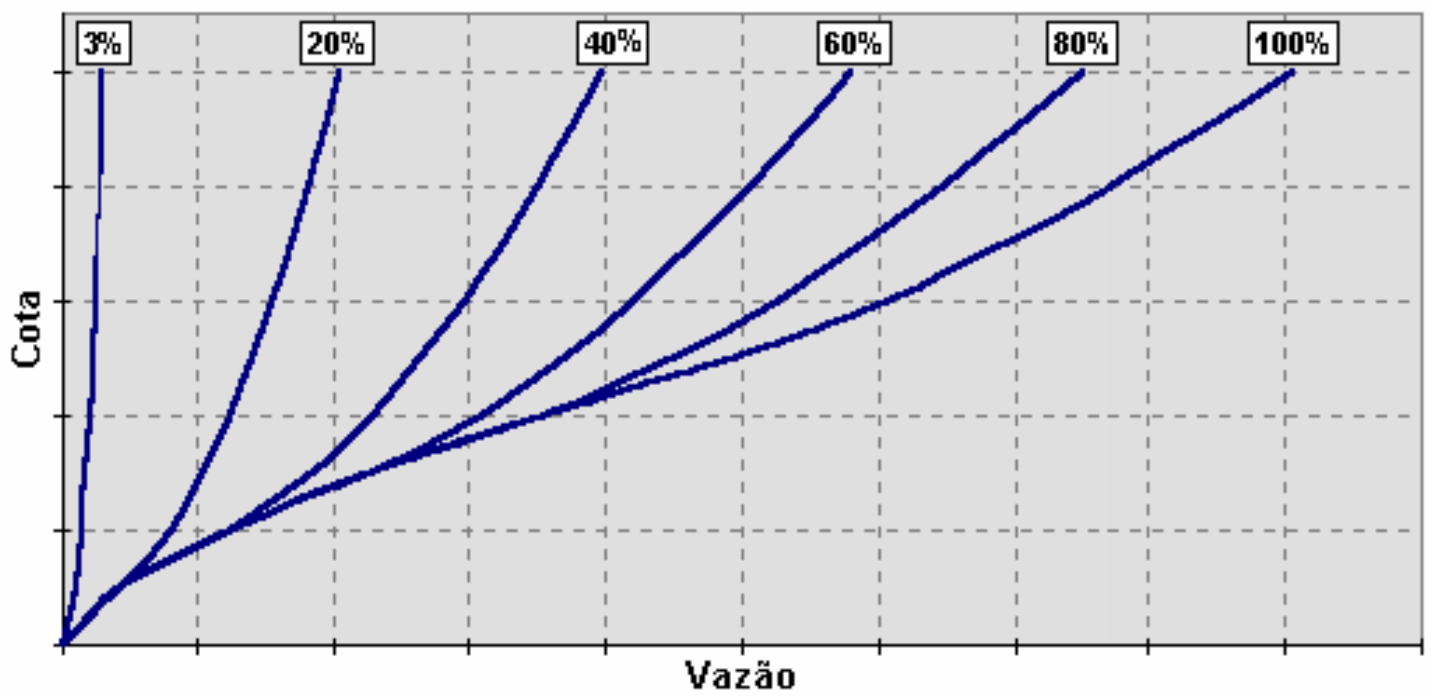

Figura 4 - Curvas de descarga para a regra operacional de comportas em um reservatório Fonte: Porto et. al. (2007)

Porto et. al. (2007) mencionam alguns princípios que devem nortear a operação de comportas: (i) a vazão efluente máxima deve ser menor que determinado número para que sejam evitados danos às áreas de jusante; (ii) a variação do nível de água em função do tempo deve ser menor que um índice específico para que não haja galgamento do reservatório; (iii) a variação da vazão máxima vertida em função do tempo deve ser menor que certo valor para evitar impactos a jusante.

Quando bem executado, o amortecimento de cheias é facilmente visualizado pela sobreposição de hidrogramas de afluência e defluência a um reservatório. A Figura 5 ilustra duas curvas onde podem ser confrontadas as grandezas de entrada e saída de água.

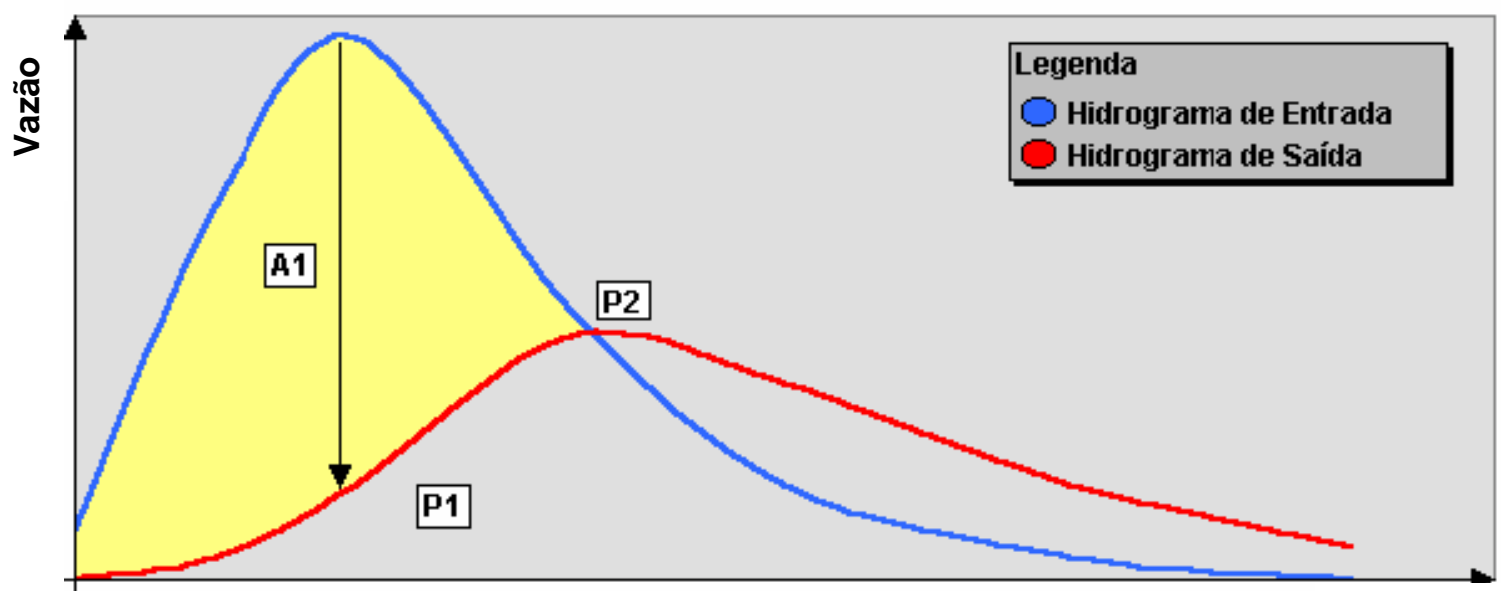

Figura 5 - Hidrogramas de entrada e saída de água em um reservatório 
Algumas propriedades a respeito dos cálculos de amortecimento de uma cheia serão discutidas (PORTO et. al., 2007; BRANDÃO, 2010).

Considerando a relação entre o nível de água e o tempo transcorrido, a velocidade de movimentação vertical da água é identificada pela sua primeira derivada. Entre zero $\left(\mathrm{Q}_{0}\right)$ e a vazão máxima de saída $\left(\mathrm{QS}_{\text {máx }}\right)$, essa velocidade é sempre positiva, já que o nível de água aumenta. Entre $\mathrm{Q}_{0}$ e a vazão máxima de entrada $\left(\mathrm{QE}_{\text {máx }}\right)$, a diferença entre a vazão de entrada $(\mathrm{QE})$ e $\mathrm{Q}_{0}$ é crescente, portanto a velocidade de subida aumenta a cada intervalo. Entre $\mathrm{QE}_{\text {máx }}$

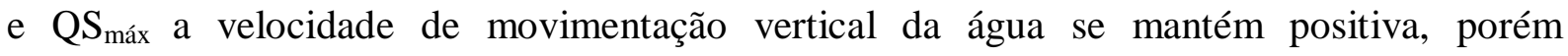
decrescente, até se igualarem. Portanto, no instante da vazão máxima de entrada $\left(\mathrm{QE}_{\text {máx }}\right)$ a variação de velocidade no tempo muda de sinal, o que caracteriza um ponto de inflexão no hidrograma de saída, demarcado na ilustração como $P 1$.

Outra observação é quanto ao ponto $P 2$. Anterior a ele, a vazão de saída é crescente e a de entrada é decrescente. Quando ambas se igualam, a efluência atinge valor máximo $\left(\mathrm{QS}_{\text {máx }}\right)$. Nesse instante, o volume armazenado no intervalo de tempo $\Delta$ t será nulo. A partir de então, esse volume começará a decair, já que é a partir desse ponto que a vazão de saída passará a ser maior que a vazão de entrada.

Por último, garantindo coerência com a equação da continuidade, o volume total de água acumulado no reservatório pode ser obtido pela subtração entre a entrada e a saída de água durante todo o processo de amortecimento da cheia. Assim, a área compreendida no espaço $A 1$, da Figura 5, corresponde ao volume total armazenado no reservatório. O cálculo do volume também pode ser feito por meio da aplicação da integral dos hidrogramas de afluência e defluência. 


\section{BACIA HIDROGRÁFICA DO RIO CUIABÁ}

A BHC está localizada exatamente no centro geodésico da América do Sul, ao sul do estado de Mato Grosso. Compreendida entre os paralelos $14^{\circ} 12^{\prime}$ e $16^{\circ} 10^{\prime} \mathrm{S}$ e meridianos 544ำ e 56 56' W, a bacia do Cuiabá integra a região hidrográfica do Alto Paraguai, a nordeste, a qual pertence à bacia do rio Paraná-Paraguai. Sua área total é de aproximadamente $41.000 \mathrm{~km}^{2}$, a qual costuma ser dividida em cinco sub-bacias: Manso: $10.800 \mathrm{~km}^{2}$ - onde se localiza a UHE Manso, Alto Cuiabá: 4.400 km², Médio Cuiabá: 8.300 km², Coxipó: 700 km² e Baixo Cuiabá: 17.200 km² (LIBOS, 2008; CUIABÁ, 2009). A definição da área da bacia do rio Cuiabá é de difícil precisão, visto que nas grandes planícies pantaneiras, como na subbacia do Baixo Cuiabá, os divisores de água e o percurso fluvial são muitas vezes indefinidos. Isso explica a diferença de valores de área da bacia entre os diversos trabalhos sobre a região.

A Figura 6 apresenta alguns aspectos sobre a localização da região hidrográfica do Alto Paraguai no continente e no estado mato-grossense, e maiores detalhes sobre a BHC.
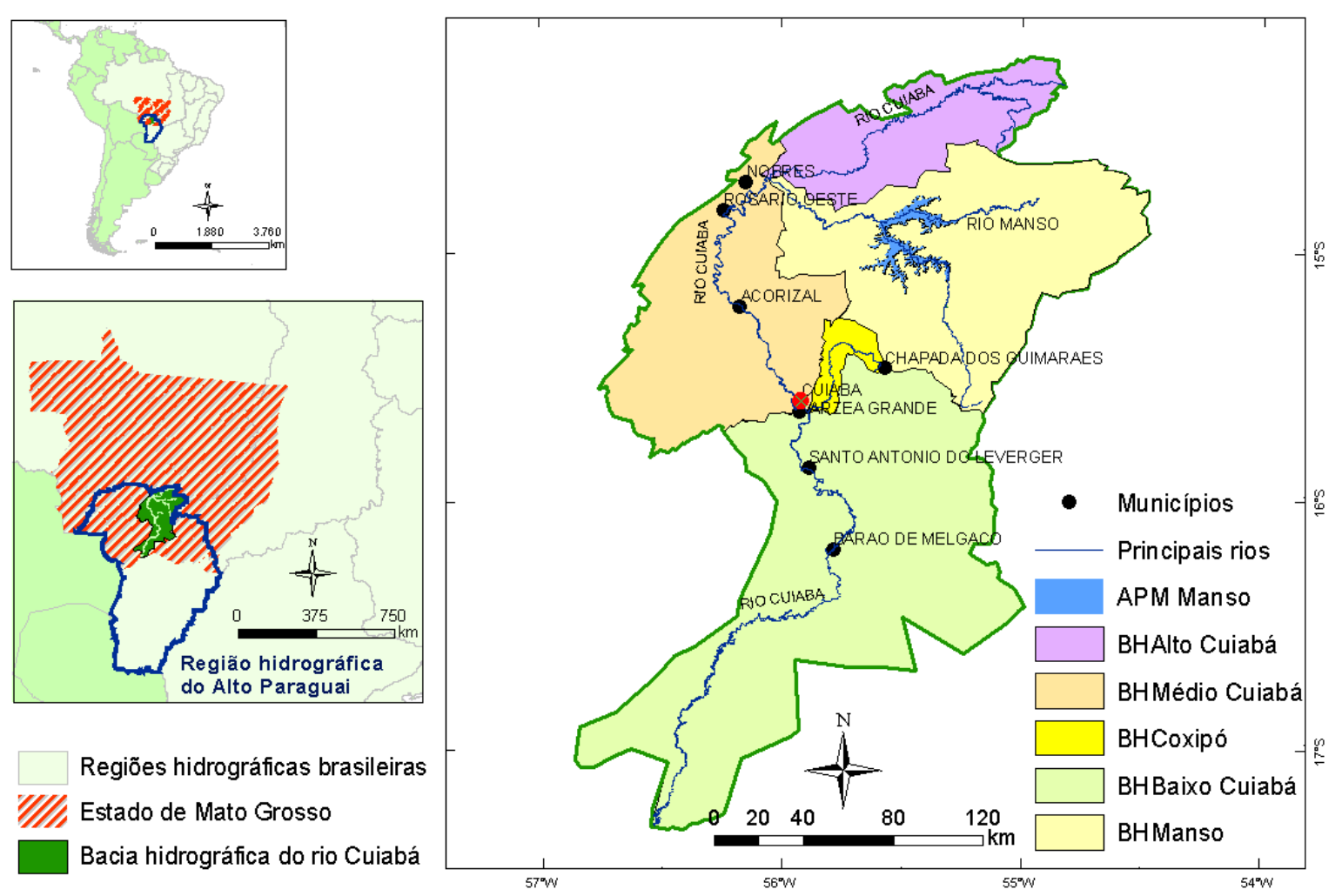

Figura 6 - Região hidrográfica do Alto Paraguai e da BHC na América do Sul 
Treze municípios fazem parte total ou parcialmente da BHC. Eles são unidos pelo rio principal da bacia e integram a região metropolitana do Vale do Rio Cuiabá, segundo a Lei Complementar n. 359 de 2009 (MATO GROSSO, 2009). Entre os que estão sob maior influência do rio Cuiabá e seus afluentes podem ser citados: Rosário Oeste, Nobres, Chapada dos Guimarães, Acorizal, Santo Antônio do Leverger, Barão de Melgaço, Cuiabá e Várzea Grande, sendo os dois últimos os principais núcleos urbanos mato-grossenses. O Censo do IBGE, divulgado em 2010, indica que as duas maiores cidades de Mato Grosso somam 800 mil habitantes, com crescimento populacional médio de $1,3 \%$ ao ano, baseado no recenseamento entre os anos 2000 e 2010.

A formação do rio Cuiabá acontece a partir da união das águas dos rios Manso e Cuiabazinho. Este último, por sua vez, é assim denominado a partir da confluência entre os rios Cuiabá da Larga e Cuiabá Bonito. O comprimento total do rio principal da BHC é de aproximadamente $980 \mathrm{~km}$ considerando a nascente pelo rio Cuiabá Bonito. O rio Cuiabá deságua no rio Paraguai, e é junto com este um dos principais contribuintes para a formação do Pantanal. Ao longo do seu curso, o rio Cuiabá possui duas características topográficas distintas. Próximo às suas nascentes, em altitudes acima dos $500 \mathrm{~m}$, o seu comportamento é semelhante ao de rios de planalto, com corredeiras na trajetória de descida da Serra Azul (LIMA, 2001). As áreas do planalto, que contornam de noroeste a leste, contornando a região central e passando pelo norte da BHC, apresentam domínio de relevo movimentado e formações geológicas areníticas, sendo mais suscetível ao desenvolvimento de erosão (SALOMÃO, 1999). Na altitude aproximada de 185 m, o rio Cuiabazinho se encontra com o Manso, quando sua declividade diminui o suficiente para surgirem algumas curvas. $\mathrm{O}$ rio Manso também tem suas nascentes em regiões planálticas. Sua declividade se torna mais suave nas proximidades da UHE Manso, onde havia a confluência com o rio da Casca. Do APM Manso em diante, enquanto a primeira metade do rio Manso possui características predominantemente retilíneas, na segunda parte já são observadas algumas curvas, até a confluência com o Cuiabazinho. A partir de então o rio Cuiabá segue na direção sul rumo ao bioma pantaneiro. Da confluência até o distrito de Engenho, no município de Acorizal, o trecho fluvial é caracterizado por grandes curvas, com indícios de mudança de leito quando há necessidade de passagem de ondas de cheia. A partir de Engenho até o distrito da Guia, no município de Cuiabá, o rio passa a ter menos curvas, a declividade aumenta em grau suficiente para serem formadas pequenas corredeiras pontuais. Nesses locais o leito do rio apresenta alguns afloramentos rochosos. Do distrito da Guia em diante a declividade diminui 
gradualmente em direção ao município de Santo Antônio do Leverger, onde atinge valores inferiores a $10 \mathrm{~cm} / \mathrm{km}$. Por fim, após receber contribuição de alguns afluentes importantes, o rio Cuiabá encontra o rio Paraguai em cota topográfica aproximada de 90 m e declividades em torno de 9 cm/km (LIMA, 2001; PALMIER et. al. 2007; PAZ, 2010).

A Figura 7 apresenta as cotas de fundo dos rios Manso e Cuiabá extraídas entre dezembro de 2009 e janeiro de 2010 a partir das topobatimetrias realizadas em 16 seções, desde a UHE Manso até o município de Santo Antônio do Leverger. De acordo com a descrição relatada do percurso fluvial, podem ser observadas as mudanças de declividade, com maiores valores nos trechos iniciais e médios, onde existem leves corredeiras; e, conforme a proximidade com o Pantanal, nas regiões a jusante, as características de planície passam a predominar. A Tabela 3 se refere às declividades entre as seções topobatimétricas medidas nos rios Manso e Cuiabá, obtido pelo mesmo levantamento topobatimétrico. Cabe relatar que a declividade média do rio Manso no percurso estudado foi de $41 \mathrm{~cm} / \mathrm{km}$, ao passo que a do rio Cuiabá foi de $20 \mathrm{~cm} / \mathrm{km}$.

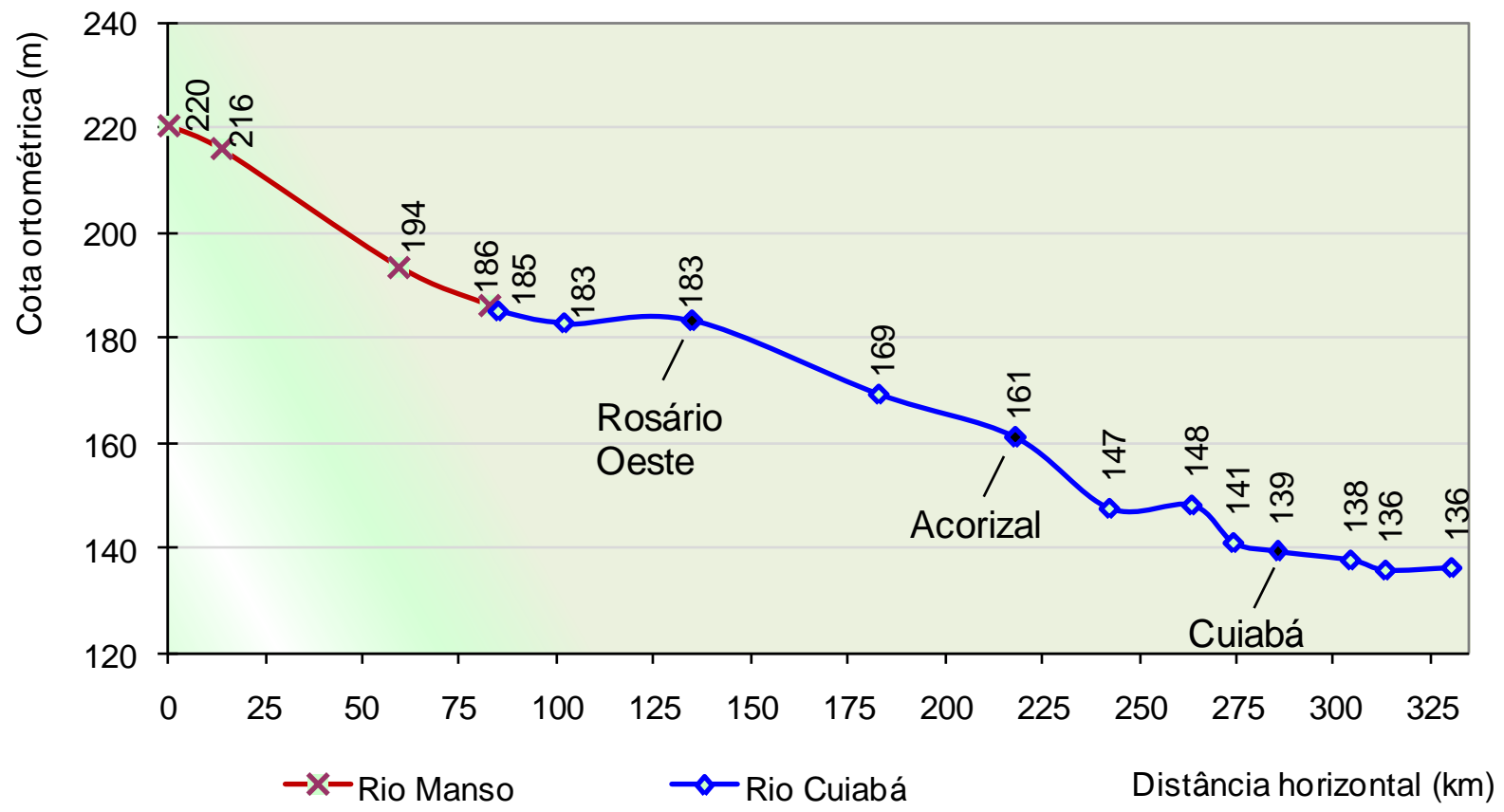

Figura 7 - Cotas de fundo dos rios Manso e Cuiabá, da UHE Manso (montante) até o município de Santo Antônio do Leverger (jusante) 
Tabela 3 - Declividades dos rios Manso e Cuiabá, da UHE Manso (montante) até o município de Santo Antônio do Leverger (jusante)

\begin{tabular}{llll}
\hline Trecho & Declividade $(\mathbf{c m} / \mathbf{k m})$ & Trecho & Declividade $(\mathbf{c m} / \mathbf{k m})$ \\
\hline 1 & 33,2 & 9 & 55,6 \\
2 & 49,0 & 10 & $-3,0$ \\
3 & 31,8 & 11 & 66,6 \\
4 & 50,4 & 12 & 15,0 \\
5 & 13,3 & 13 & 8,6 \\
6 & $-1,6$ & 14 & 21,3 \\
7 & 29,2 & 15 & $-2,8$ \\
8 & 23,3 & & \\
\hline
\end{tabular}

Em relação à pedologia, na BHC há o predomínio de solos com caráter álico, acrescido de limitações físicas como concreções e pouca profundidade em algumas regiões. Os latossolos, especialmente os vermelhos, os neossolos litólicos (denominados pela Embrapa de litossolos até 1999), os neossolos quartzarênicos (antes cognominados areias quartzosas) e os cambissolos são os tipos mais comuns nas superfícies quase planas das chapadas e nas áreas de relevo suavemente ondulado. Ao sul da bacia predominam os plintossolos e os planossolos, com relativa representatividade de solos gleizados nos trechos ao longo do rio principal e de alguns afluentes a partir do trecho médio da bacia. Grande porção de solos concrecionários é encontrada na região intermediária da BHC. Os latossolos e os neossolos quartzarênicos podem ser classificados como de baixo potencial de escoamento superficial; os cambissolos, médio; e os neossolos litólicos e os gleizados, alto potencial (LIBOS, 2008; FIGUEIREDO e SALOMÃO, 2009).

A vegetação predominante na bacia hidrográfica do rio Cuiabá é a savana, ou cerrado, que pode ser subdividida em diversas tipologias de acordo com a constituição local. As características principais do cerrado são a formação de gramíneas espalhadas pela cobertura do solo e de árvores relativamente baixas, espaçadas entre si, de corpo lenhoso e retorcido. Os fatores preponderantes para a diferenciação da estrutura da vegetação de savana dependem do tipo de solo, da profundidade do nível de água subterrâneo e da composição da rocha matriz.

A bacia do rio Cuiabá possui expressivo potencial de recarga de água subterrânea, o que ocorre por infiltração nas fraturas das rochas ou pelos poros areníticos, quando há formação arenosa. Na região pantaneira, em especial durante as cheias, a recarga de maneira direta ou pela circulação das águas que são infiltradas na borda do pantanal (SAAF, 2003). 
A BHC possui ciclos hidrológicos muito bem definidos: enquanto os índices pluviométricos dos meses entre outubro e abril são responsáveis pela precipitação de aproximadamente $80 \%$ do volume anual, no período compreendido entre maio e setembro, a quantidade precipitada é consideravelmente reduzida. Segundo SAAF (2003), as médias mensais são superiores a $200 \mathrm{~mm}$ entre dezembro a março e inferiores a $15 \mathrm{~mm}$ nos meses de junho a agosto. Entre as precipitações máximas mensais, o mesmo trabalho apontou que estes valores foram superiores a $400 \mathrm{~mm}$ nos meses de dezembro a fevereiro, e inferiores a $70 \mathrm{~mm}$ entre junho e agosto. A precipitação média anual na BHC é em torno de $1500 \mathrm{~mm}$.

Lima (2005) comenta que as chuvas prevalecentes nessa região são convectivas de mesoescala bastante localizadas, com abrangência espacial entre 2 e $50 \mathrm{~km}$. De acordo com Musis (1997), as precipitações máximas da bacia hidrográfica do rio Cuiabá costumam ocorrer nas cabeceiras. Isso pode ser observado na Figura 8, onde são ilustrados os resultados da interpolação entre os valores médios anuais de chuva obtidos em 30 estações pluviométricas localizadas no interior e nas proximidades da bacia. Nela é possível notar menores precipitações ao sul e sudoeste, onde se localiza a região pantaneira, e maiores precipitações ao norte e nordeste, região de nascente dos principais cursos de água da $\mathrm{BHC}$, entre os quais, os rios Cuiabá e Manso.

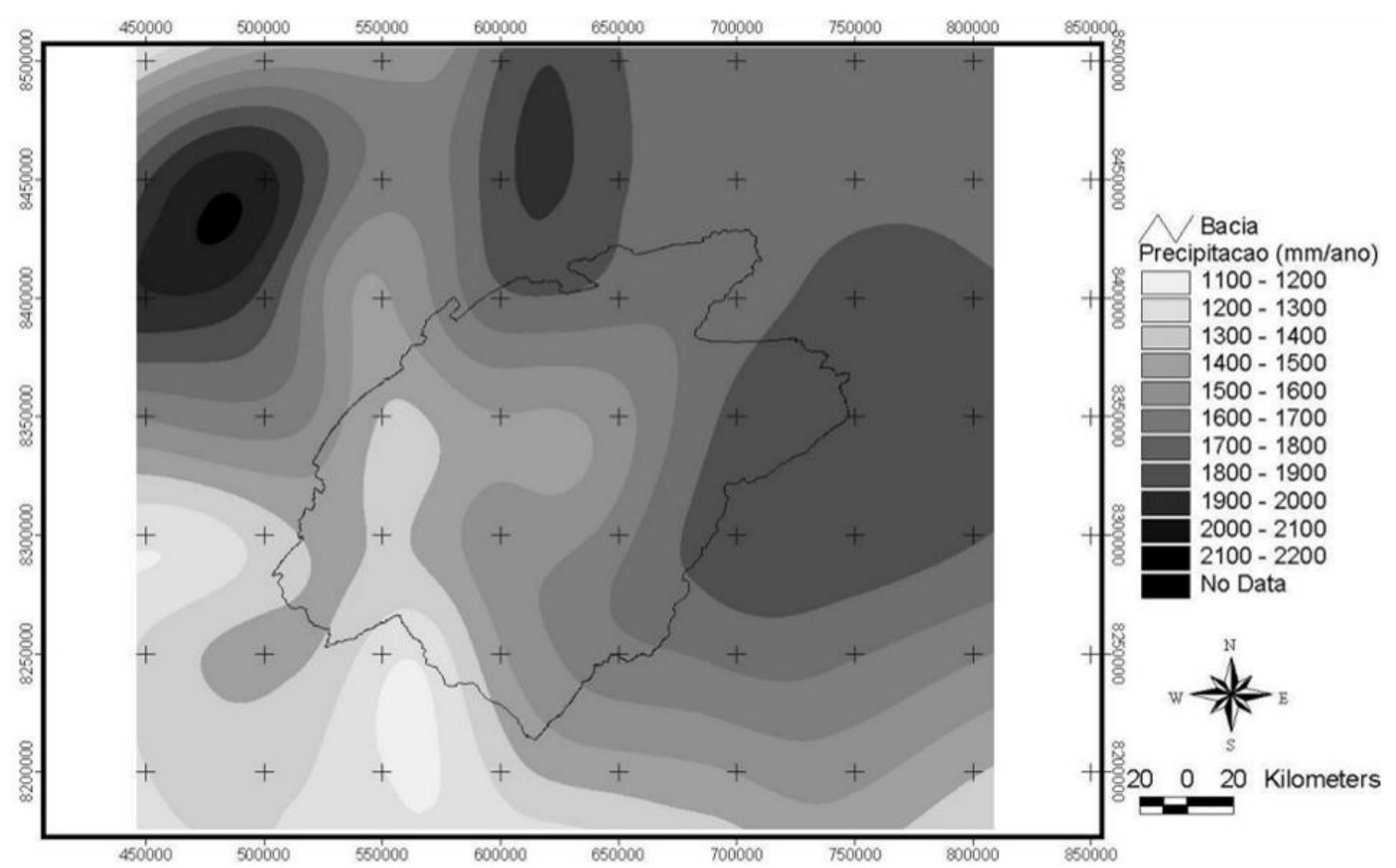

Figura 8 - Pluviosidade na BHC

Fonte: Libos, Rotunno Filho e Zeilhofer (2003) 
SAAF (2003) apontou que a umidade relativa média do ar medida na estação climatológica de Cuiabá é de aproximadamente 73\%, com variação entre 55\% em agosto, e $85 \%$ em janeiro e fevereiro. A evaporação total média anual é de cerca de $1.300 \mathrm{~mm} / \mathrm{ano}$, equivalente a $3,6 \mathrm{~mm} / \mathrm{dia}$.

A temperatura média anual na bacia do Cuiabá varia de 22 a $25^{\circ} \mathrm{C}$, enquanto a mínima média anual está compreendida entre 17 e $20^{\circ} \mathrm{C}$ e a máxima média anual entre 29 e $32^{\circ} \mathrm{C}$. Na metodologia de Köeppen, a denominação dada aos climas em que todos os meses do ano têm temperatura média mensal superior a $18^{\circ} \mathrm{C}$ e pelo menos um dos meses do ano possui precipitação média total inferior a $60 \mathrm{~mm}$ é a $A w$. Esta é a classificação recebida pela $\mathrm{BHC}$, de acordo com Musis (1997). Tal designação é descrita como de clima tropical quente e semiúmido, com sazonalidade marcada por dois períodos distintos: seco e chuvoso.

Lima (2001) estudou os valores de vazão registrados no rio Cuiabá, na capital matogrossense, entre os anos de 1948 e 1998, portanto, antes da implantação da UHE Manso. Os valores médios máximos mensais variaram entre $400 \mathrm{~m} 3 / \mathrm{s}$ e $1.000 \mathrm{~m} 3 / \mathrm{s}$ nos meses de janeiro a março, enquanto as vazões médias mínimas foram inferiores a $100 \mathrm{~m} 3 / \mathrm{s}$ nos meses de agosto e setembro.

Em levantamento sobre o uso e a ocupação do solo na bacia do rio Cuiabá, Libos (2008) apontou que no ano 2000 aproximadamente 11,8\% da BHC estava antropizada (plantação, solo aberto e cidade); assim, pouco mais de $88 \%$ da área estava inexplorada. As composições de ocupação da bacia são: savana - 57,4\%; pasto - 20,3\%; solo aberto $8,4 \%$; mata ciliar $-8,1 \%$; agricultura $-2,8 \%$; água $-0,9 \%$; cidade $-0,6 \%$; e sombra $-1,4 \%$. Ao comparar estes resultados com os dados do ano 1995 apresentado por Brasil (1997b), Libos (2008) constatou que não houve significativas modificações. A classificação de uso e ocupação do solo foi baseada nas imagens digitais do satélite Landsat 7 - ETM+, obtida em julho de 2000, a qual é apresentada na Figura 9. 


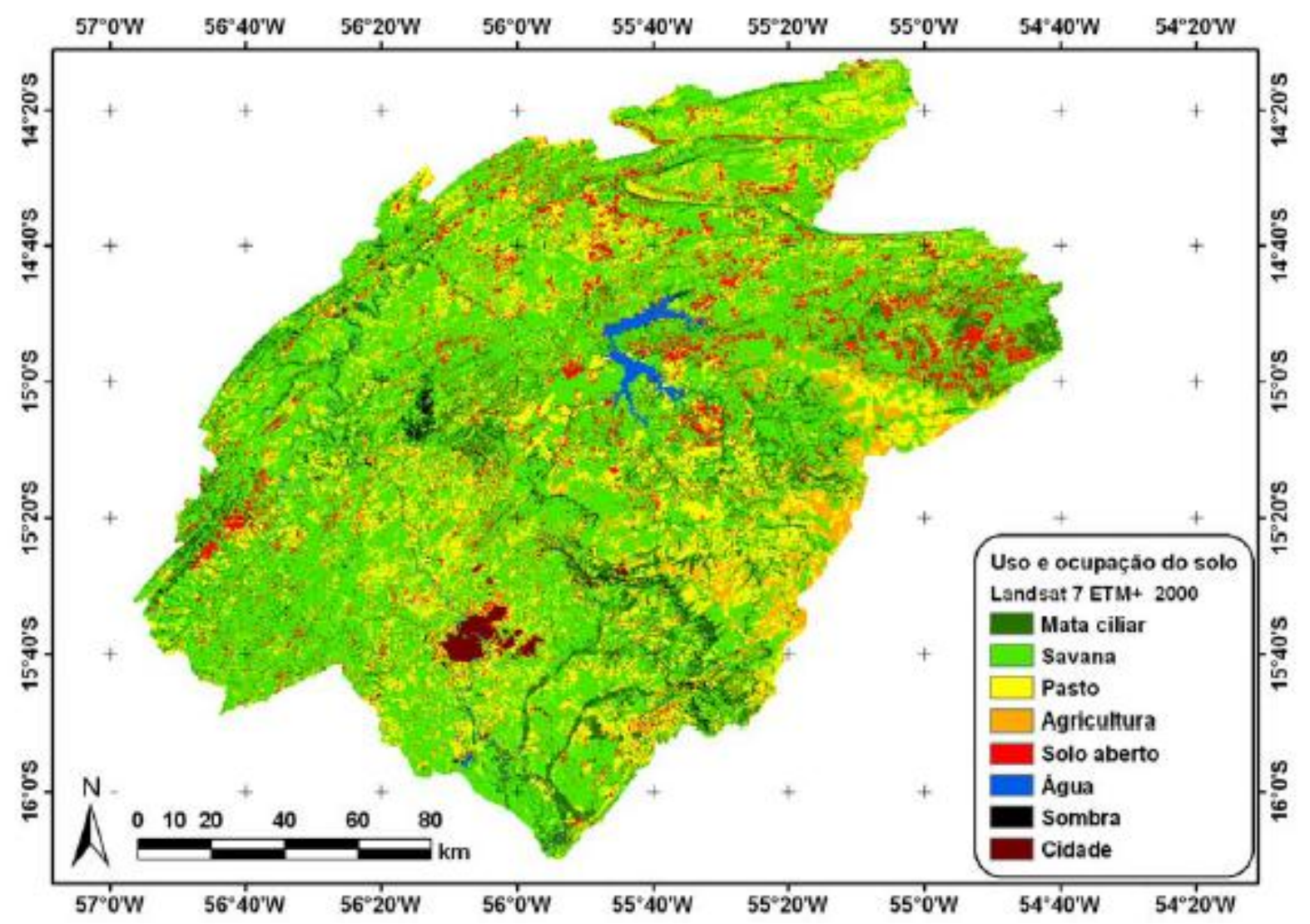

Figura 9 - Uso e ocupação do solo da BHC - Jul/2000

Fonte: Libos (2008)

Em relação ao uso do solo no percurso do rio Manso, a partir da usina hidrelétrica, Palmier et. al. (2007) relatou o predomínio de pastos e árvores de pequeno porte intercalando a ocupação das suas margens. Ao longo do rio Cuiabá, de modo geral, essa característica só se altera nas proximidades de chácaras, normalmente com residências de pequeno porte, ou nas cidades e distritos municipais, quando há avanço da ocupação sobre as planícies, sobretudo próximo à região metropolitana.

\subsection{Considerações sobre as estações fluviométricas na BHC}

A estação fluviométrica de Cuiabá (código ANA 66260001), na zona urbana deste município, afere informações sobre a área aproximada de $23.500 \mathrm{~km}^{2}$ da BHC. Sua régua fluviométrica foi instalada em janeiro de 1933, e foi operada pelo DNAEE, DNOS, Eletronorte e atualmente por Eletrobrás Furnas. Desde sua instalação sofreu dois períodos de paralisação de leituras: setembro de 1946 a dezembro de 1948 e outubro de 1957 a abril de 1959. 
A estação foi instalada em região de leito instável. Segundo Furnas (2002), a instabilidade se deve à grande quantidade de areia extraída das margens e do leito do rio Cuiabá por empresas de exploração mineral para utilização na construção civil, mormente na zona metropolitana. Por esse motivo, a curva-chave da estação Cuiabá se altera ao longo dos anos, o que requer constantes medições de descarga para sua atualização. Outro fator que provavelmente tem causado modificação do leito do rio é a retenção de material sólido pela barragem da UHE Manso. Provavelmente em decorrência disso, tem sido observado o desaparecimento de bancos de areia e de localidades praieiras em muitos locais do rio Cuiabá.

Na segunda metade da década de 1960, três importantes estações fluviométricas foram instaladas na bacia do Cuiabá. De montante para jusante, são elas: a estação Rosário Oeste (66250001), operada a partir de 1966; a estação Acorizal (66255000), a partir de 1965; e a estação Santo Antônio do Leverger (66270000), a partir de 1967. Todas possuem a denominação dos municípios onde se localizam.

Durante as décadas de 1970 e 1980, diversas estações fluviométricas foram instaladas, ou reativadas, grande parte para subsidiar o projeto básico da construção da UHE Manso, muitas das quais foram posteriormente desativadas. Entre as que permanecem em operação, cita-se a estação Quebó (66160000), no município de Nobres, a qual a partir de 1972 possibilitou melhores estudos fluviométricos no rio Cuiabazinho, um dos formadores do rio Cuiabá junto com o Manso. Em julho de 1981, o DNOS instalou a estação Fazenda Raizama (66231000), localizada a aproximadamente $14 \mathrm{~km}$ a jusante do eixo da barragem da usina de Manso; e em agosto de 1982 a estação Jusante Eixo Barragem MAN F4 (66210000), a cerca de $8 \mathrm{~km}$ a jusante da barragem. Conforme Furnas (2002), a escolha dos locais para instalação das estações imediatamente a jusante da barragem foi em função da facilidade para o cálculo de vazão, em regiões com características de margem encaixada e alta.

\subsection{Modelagens na bacia do rio Cuiabá}

Pelo fato de a bacia do rio Cuiabá estar inserida na região hidrográfica do Paraguai e ser um dos principais rios na formação do Pantanal, bioma de extrema importância para o continente, há uma série de trabalhos sobre ela. Com a construção da UHE Manso no final dos anos 1990 e a intensificação dos cursos de pós-graduação no estado e no país, diversos estudos têm sido realizados a fim de contribuir com a bacia hidrográfica, de forma geral. Entre as pesquisas cuja temática principal é a modelagem hidráulica ou hidrológica, quer na região hidrográfica do rio Alto Paraguai (RHAP), quer na bacia hidrográfica do rio Cuiabá 
(BHC), ou na sub-bacia hidrográfica do rio Manso (BHM), alguns trabalhos serão comentados.

Em análise estatística referente ao monitoramento hidrológico na BHC para desenvolvimento de um modelo matemático para restituição de vazões à sub-bacia do rio Manso a jusante da usina, e assim garantir as vazões mínimas exigidas em Cuiabá, Silva e Braga (2000) estimaram o tempo de trânsito da água entre a UHE Manso e as estações fluviométricas a jusante: UHE Manso até a estação de Rosário Oeste - 1 dia; UHE até a estação de Acorizal - entre 1 e 2 dias; UHE até a estação de Cuiabá - 2 dias. Por fim, os autores classificaram como aplicável e de fácil manuseio o modelo adotado pela então empresa Furnas (atual Eletrobrás Furnas); contudo, parte dele, relativa à previsão de cheias à montante do reservatório, deveria ser aprimorada quando na fase de operação do reservatório.

Com foco na sub-bacia hidrográfica de Manso, Libos (2008) fez um comparativo de quantidade e qualidade de água através de três abordagens distintas: diagnóstico de longo curso por análise de regressão e sistema de informações geográficas - SIG, modelo concentrado SMAP suavizado diário e modelo distribuído MGB-IPH diário. Através da primeira abordagem, a autora identificou a potencialidade da bacia para a poluição por nitrogênio e fósforo devido ao tipo de uso do solo. A autora desenvolveu estudos integrados de quantidade e qualidade de água via modelos chuva-vazão concentrado e distribuído. Seus resultados foram bastante satisfatórios, com produtos diários de quantidade e qualidade de água. De maneira geral, o SMAP suavizado se mostrou mais eficiente que o MGB-IPH ao serem avaliados os volumes das vazões observadas e simuladas pelos modelos durante a calibração.

Um grupo de pesquisa da Universidade Federal de Minas Gerais tem realizado uma série de trabalhos que envolvem modelagem hidrodinâmica e SIG para representação das áreas a serem inundadas em situações hipotéticas de ruptura de barragens de usinas hidrelétricas considerando a propagação resultante da onda de cheia. Palmier et. al. (2007) utilizou o modelo matemático FLDWAV para estudar o caso da barragem da UHE Manso e gerar os mapas de inundação do rio Manso até a confluência com o rio Cuiabazinho a partir de informações topobatimétricas da calha fluvial dos rios Manso e Cuiabá e de dados cartográficos fornecidos gratuitamente pelo IBGE. Houve instabilidade do modelo hidrodinâmico, isso exigiu que a vazão de ruptura utilizada para alimentar o modelo fosse menor que a calculada para essas ocasiões. Segundo o autor, este é um trabalho preliminar, e 
os próximos serão realizados a partir de mapas vetorizados da região de estudo com distância de curvas de nível muito mais adequadas ao tipo de análise; além de dados topobatimétricos intermediários em maior quantidade, visto que as insuficientes informações de topobatimetria foram consideradas a provável razão da instabilidade do modelo.

Baseado na avaliação estatística e de dados hidrometeorológicos da BHC, Shirashi (2003) analisou as vazões médias e máximas do rio Cuiabá para estudar a alteração do seu comportamento depois da construção da UHE Manso. O autor ainda elaborou mapas de inundação com diferentes períodos de retorno a partir de modelo numérico de terreno gerado com dados até 1999. Shirashi (2003) defendeu que as regras operacionais da usina provavelmente não caracterizariam conflito para o controle da cheia, pois os níveis de água tenderiam a se manter na cota mínima operacional devido à baixa vazão afluente ao reservatório. Entretanto, essa cota não é atingida desde 2001, durante a fase de enchimento. Cabe salientar que os dados disponíveis para o trabalho do autor eram até 2002, ou seja, menos de dois anos depois do início da operação da usina. Essas observações não significam que os objetivos em produzir energia elétrica estejam sendo conflitantes com a regularização de vazões do reservatório. Quanto ao controle de cheias, o autor afirmou que a usina se apresentou como uma eficaz medida estrutural até então. Para a segurança da população e maior controle da Defesa Civil, o autor sugeriu, a partir de seu trabalho, a elaboração de mapas de risco bem detalhados em Cuiabá e Várzea Grande, onde são indicadas as áreas inundáveis. Por último, foi advertido que "o critério de cotas de alerta adotado pela Defesa Civil necessita ser incrementado com a inclusão da análise da vazão, uma vez que em rios de leitos de fundo móvel (...) não se pode precisar o volume de água e a extensão dessas áreas inundáveis".

Ao ressaltar a importância de manter o pulso anual de inundação do bioma pantaneiro, Moura (2006) propôs vazões de operação do APM Manso de modo que fossem minimizados os efeitos provocados pela regularização do regime hídrico do rio Cuiabá, baseado na adequação de vazão turbinada, e produzindo energia em média escala. A sugestão é que sejam dispostas as mínimas vazões possíveis para o sistema em época de estiagem e incrementandoas nos meses de cheia, de modo a respeitar a dinâmica fluvial natural do Pantanal para a garantia do equilíbrio ecológico deste sistema. Entre outras sugestões, posteriormente reafirmadas por Calheiros et. al. (2009), foi observada a importância da não alteração em nível diário dos valores das vazões efluentes ao reservatório, assim como cobrada maior atenção à sensibilidade ao regime hídrico pantaneiro para a fauna e a flora. 
Oliveira (2003) simulou previsões de vazões em tempo real na afluência do APM Manso e analisou o provável impacto dessas previsões nas comunidades influenciadas pelo reservatório. O modelo matemático utilizado foi o SSARR, e a análise foi sobre a cheia ocorrida no primeiro trimestre de 1995, período com maior volume precipitado já registrado na BHC. A autora obteve valores de vazões previstas classificadas como razoáveis, "mesmo em estações fluviométricas que apresentam calibragem de modelo chuva-vazão com índices de aceitação baixos". Segundo ela, os valores encontrados permitem sua utilização na operação de reservatórios, porém, não aconselha repassar as informações de previsões de vazões e níveis de água à população local.

Souza et. al. (2009) analisou as alterações hidrológicas causadas pela barragem de Manso dez anos após o início da sua operação especificamente no que diz respeito à magnitude e ao tempo de translação das águas para as vazões médias anuais máximas e mínimas. Foram utilizadas análises estatísticas das vazões medidas em 13 estações fluviométricas a jusante da usina. Entre outras constatações, os resultados preliminares identificaram que a usina influencia o controle do pico de cheias do rio Cuiabá até as proximidades do município de Cuiabá e Várzea Grande; ao passo que o controle sobre as vazões mínimas atinge região pouco a montante dessa região metropolitana.

Por meio do Serviço de Sinalização Náutica do Oeste, o Ministério da Defesa, através da Marinha do Brasil, divulga informações a respeito da hidrovia Paraguai-Paraná ${ }^{6}$. Entre os serviços úteis ao transporte fluvial, são divulgados, por exemplo, previsões de níveis de água de diversos rios do Pantanal e a atualização diária das leituras desses níveis, exposta em gráficos mensais, nos rios Cuiabá e Paraguai, em seis estações fluviométricas. Os pontos a montante são as estações de Cuiabá, no rio Cuiabá, e de Cáceres, no rio Paraguai, ambos em Mato Grosso, já o ponto a jusante é a estação de Porto Murtinho, no estado de Mato Grosso do Sul.

Conforme comentado, diversas pesquisas têm sido desenvolvidas na região hidrográfica do Alto Paraguai (RHAP) com a intenção de conhecer o comportamento dos pulsos de inundações e estiagens no Pantanal como um todo. Nesse contexto, ANA/AGEF/PNUMA/OEA (2005) é um minucioso trabalho de modelagem, talvez o mais

\footnotetext{
${ }^{6}$ Sítio eletrônico do Serviço de Sinalização Náutica do Oeste - Informações úteis da Hidrovia Paraguai-Paraná: https://www.mar.mil.br/ssn-6/hidrovia.html.
} 
completo já realizado na RHAP. Sua metodologia consistiu na combinação do modelo hidrológico distribuído MGB-IPH com o hidrodinâmico unidimensional HEC-RAS e com um modelo de células de armazenamento conectadas aos rios para simular o volume de água amortecido pelas planícies de inundação. Foram representados o rio Paraguai e todos os principais tributários, entre os quais se inclui o rio Cuiabá. O estudo foi posteriormente continuado por Allasia (2007) e em seguida por Paz (2010). Tendo em mente as dificuldades quanto à escassez de dados, este último autor avalia os resultados como "muito bons" em termos de reprodução de regime de vazões, apesar da inviabilidade para a simulação de manchas de inundação.

Comentário comum a todos os trabalhos realizados quer na RHAP ou na $\mathrm{BHC}$, ou ainda na BHM, é quanto à dificuldade dos estudos e simulações em razão da falta de informações para alimentar as pesquisas, o que compromete integral ou parcialmente a qualidade dos trabalhos. Há escassez nos dados de topografia, hidráulicos e meteorológicos, e todos os pesquisadores sugerem maior atenção para a ampliação da rede hidrometeorológica.

Todas essas carências dificultam, ainda, as tomadas de decisões a respeito da produção ótima de energia elétrica do Sistema Interligado Nacional, pela Agência Nacional de Energia Elétrica (ANEEL), bem como a gestão dos recursos hídricos, pela ANA. Para contribuir com a solução desse problema, a Resolução Conjunta entre a ANEEL e a ANA n. 03 de 2010 (BRASIL, 2010d), estabelece condições e procedimentos a serem observados pelos concessionários e autorizados de geração de energia hidrelétrica para a instalação, operação e manutenção de estações hidrométricas visando ao monitoramento pluviométrico, linimétrico, fluviométrico, sedimentométrico e de qualidade da água associado a aproveitamentos hidrelétricos. Ao defender a elevada responsabilidade das empresas geradoras de energia elétrica sobre o levantamento das informações hidrométricas no Brasil, Oliveira (2003) sugere que se avaliem a possibilidade de novas regulamentações que obriguem a instalação e operação de estações hidrológicas telemétricas por parte de outros grandes usuários de água. 


\section{CENÁRIOS}

Os cenários hidráulicos estudados na bacia hidrográfica do rio Cuiabá tiveram por fundamento a análise do escoamento fluvial a jusante da UHE Manso em três diferentes hipóteses:

(i) A inexistência do reservatório nos anos hidrológicos de maiores cheias em Cuiabá após a construção do APM Manso (cheias 11, 12 e 13, relativas a março de 2002, março de 2004 e abril de 2006);

(ii) A existência do reservatório de Manso em anos hidrológicos com registros de vazão cujas cheias causaram maiores prejuízos nos municípios banhados pelo rio Cuiabá (cheias 1, 7 e 8, atinentes a maço de 1974, janeiro 1995 e fevereiro 1995);

(iii) A ocorrência de cheias de projeto com tempos de recorrência pré-determinados 50, 100, 1.000 e 10.000 anos, além da vazão máxima provável (QMP) - na área de influência a montante do reservatório de Manso, estimando seu amortecimento.

Na primeira categoria dos cenários, a vazão afluente ao APM Manso foi utilizada para alimentar a condição de contorno a montante do sistema, como se não houvesse o efeito amortecedor do reservatório; enquanto foram mantidas as demais características de cada cheia, entre elas o hidrograma do rio Cuiabazinho e a vazão específica da bacia incremental.

A segunda e a terceira classe de cenários foram analisadas a partir da simulação teórica do amortecimento de cheias proporcionado pelo reservatório. Para cada cheia, a combinação do Método de Puls, ou level pool routing, com a operação das comportas da UHE Manso resultaram nos hidrogramas efluentes ao reservatório, e que foram utilizados como condição de contorno a montante do sistema na aplicação do modelo matemático. Os dados de entrada no cálculo do amortecimento do reservatório foram as vazões do rio Manso na ocorrência das maiores cheias já registradas - cenário (ii) - e as vazões naturais associadas aos períodos de retorno considerados - cenário (iii). Tais hidrogramas críticos foram calculados ainda na época dos estudos para a implantação da usina, com o auxílio modelo Riba, do tipo chuva-deflúvio (Furnas, 2002), com base nos históricos de precipitações diárias observadas em diversas estações pluviométricas. 
Os resultados, dispostos mormente em termos de níveis de água do rio Cuiabá em função do tempo, serão comparados com os limites já conhecidos deste rio tanto em relação às cotas de alerta, emergência e calamidade estabelecidas pela Defesa Civil estadual, quanto a níveis já atingidos por inundações em anos anteriores na zona urbana das cidades de Cuiabá, Acorizal e Rosário Oeste.

A Tabela 4 apresenta uma síntese de todas as simulações realizadas neste trabalho, classificadas em um dos três cenários definidos. Vale notar que para cada uma das 11 simulações relativas à data - ou ao período de retorno, para o cenário (iii) - serão analisados os resultados nos três municípios mencionados, o que totalizará 33 situações.

Tabela 4 - Simulações realizadas para cada cenário

\begin{tabular}{ll}
\hline CENÁRIO & DATA / PERÍODO DE \\
& RETORNO \\
\hline \multirow{2}{*}{ (i) } & Mar 2002 \\
& Mar 2004 \\
& Abr 2006 \\
& Mar 1974 \\
(ii) & Jan 1995 \\
& Fev 1995 \\
& \\
& TR 50 anos \\
& TR 100 anos \\
(iii) & TR 1.000 anos \\
& TR 10.000 anos \\
& Vazão Máxima Provável \\
\hline
\end{tabular}




\section{DADOS DE ENTRADA}

A alimentação do modelo CLiv foi baseada em dois tipos de dados: os hidráulicos e os geométricos. Os primeiros estão relacionados com os hidrogramas que definiram a condição de contorno interna e a externa de montante; além da curva-chave, para a lei de contorno externa de jusante do regime transitório. Os dados geométricos consistem nas informações das seções topobatimétricas ao longo do canal estudado.

\subsection{Dados hidráulicos}

As principais informações hidráulicas utilizadas dizem respeito aos hidrogramas de locais específicos no trajeto barragem de Manso - Cuiabá por meio das estações fluviométricas, que permitem a mensuração dos dados de vazão por meio da curva de descarga para compor as séries históricas. Três principais fontes foram consultadas, em ordem de preferência de aplicação: Operador Nacional de Sistema - ONS; o serviço Hidroweb, da ANA; e Furnas/UFMT. A ordem de preferência foi selecionada em função da garantia da qualidade das informações. As vazões da ONS são oficialmente consistidas em termos estatísticos, assim como os dados da ANA quando apresentam nível de consistência 2, (os com nível 1 não passaram por apreciação estatística), já os valores disponibilizados por Furnas/UFMT são brutos, portanto também não têm sua consistência analisada.

Durante os vários estudos para a construção da usina, muitas estações fluviométricas foram instaladas provisoriamente no rio Manso para o conhecimento das informações hidrológicas (FURNAS, 2002). As constantes interrupções na operação de umas estações para instalação de outras resultou em várias séries históricas sobrepostas e com algumas lacunas temporais. Em função das intermitências das vazões, três estações fluviométricas posicionadas próximas entre si foram empregadas na atual pesquisa para representar a vazão do rio Manso em um único ponto, definido como Jusante Eixo da Barragem do APM Manso, código 66210000, que é utilizado atualmente pela Eletrobrás Furnas para a determinação da efluência da UHE Manso.

As três estações se complementam em termos cronológicos e se diferem na área de drenagem no máximo em 200 km²; valor que, frente à área da sub-bacia de Manso, praticamente elimina a diferença da descarga hídrica entre os pontos. De qualquer maneira, 
para a consideração das três estações representarem as informações de uma só, houve o cuidado de distribuir a vazão à área de drenagem proporcional.

Isso permitiu a obtenção da série histórica coincidente entre os cinco pontos de interesse na BHC entre julho de 1972 e agosto de 1979, e entre julho de 1981 e dezembro de 2009, totalizando 423 meses de observações (equivalente a pouco mais de 35 anos) sem contar as poucas falhas entre alguns meses fora dos períodos de cheia. As sete estações utilizadas para obtenção dos hidrogramas na bacia do rio Cuiabá, são apresentadas na Tabela 5, e as suas localizações podem ser visualizadas no APÊNDICE B.

Tabela 5 - Estações fluviométricas utilizadas para obtenção dos hidrogramas

\begin{tabular}{|c|c|c|c|}
\hline Nome da estação fluviométrica & $\begin{array}{l}\text { Código } \\
\text { ANA }\end{array}$ & Rio & $\begin{array}{l}\text { Série histórica disponível } \\
\text { (até dez 2009) }\end{array}$ \\
\hline Jusante eixo barragem MAN - F4 & 66210000 & Manso & $\begin{array}{l}\text { Ago- } 1982 \text { a dez-1990 e nov-1999 } \\
\text { a dez-2009 }\end{array}$ \\
\hline Fazenda Raizama & 66231000 & Manso & Jul-1981 a set-2006 \\
\hline Porto de Cima & 66240000 & Manso & Jul-1972 a ago-1979 \\
\hline Quebó & 66160000 & Cuiabazinho & Ago-1972 a dez-2009 \\
\hline Rosário Oeste & 66250001 & Cuiabá & Jan-1966 a dez-2009 \\
\hline Acorizal & 66255000 & Cuiabá & Dez-1965 a dez-2009 \\
\hline Cuiabá & 66260001 & Cuiabá & Jan-1960 a dez-2009 \\
\hline
\end{tabular}

Fonte: ANA

Com as vazões disponíveis nas cinco seções principais da bacia durante os 35 anos do período mencionado, foi feita a ordenação das maiores cheias no rio Cuiabá, na estação localizada na capital do estado. Em seguida, foram selecionadas as 13 maiores ocorrências no município e construídos os hidrogramas em todas as cinco seções para a posterior calibração do modelo. Como as informações eram quase sempre diárias com leitura de nível linimétrico às $7 \mathrm{~h}$ ou de no máximo três vezes por dia $(7 \mathrm{~h}, 12 \mathrm{~h}$ e $17 \mathrm{~h})$, foi feita a discretização linear horária das vazões para a construção desses hidrogramas.

As 13 cheias de maiores proporções no rio Cuiabá dentro do período compreendido pela disponibilidade de vazões nas estações fluviométricas nos rios Manso, Cuiabazinho e Cuiabá são apresentadas na Tabela 6. 
Tabela 6 - Maiores cheias em Cuiabá com disponibilidade de vazão nas principais estações fluviométricas da $\mathrm{BHC}$

\begin{tabular}{llll}
\hline Mês/Ano & Vazão máx $\left(\mathbf{m}^{3} / \mathbf{s}\right)$ & Mês/Ano & Vazão máx $\left(\mathbf{m}^{3} / \mathbf{s}\right)$ \\
\hline Mar/1974 & $3.007,00$ & Fev/1995 & $3.479,34$ \\
Fev/1982 & $2.323,40$ & Mar/1996 & $1.997,76$ \\
Mar/1982 & $2.056,80$ & Fev/1997 & $2.574,15$ \\
Dez/1987 & $2.018,40$ & Mar/2002 & $2.057,89$ \\
Jan/1988 & $2.218,00$ & Mar/2004 & $1.988,12$ \\
Mar/1989 & $2.190,00$ & Abr/2006 & $1.928,80$ \\
Jan/1995 & $3.201,33$ & & \\
\hline
\end{tabular}

Enquanto o hidrograma do rio Manso foi utilizado como condição de contorno externa de montante, a curva-chave da seção em Cuiabá foi estabelecida como a condição de contorno externa de jusante. Como esta última seção é móvel, portanto com curvas de descarga que se modificam ao longo do tempo, foi respeitado o ano em que cada cheia ocorreu no aceite das condições de contorno de jusante.

Além da curva-chave que a Eletrobrás Furnas utiliza desde 1999, foram encontradas outras duas (LIBOS, 2008; SAAF, 2003) para a estação fluviométrica em Cuiabá. A análise de aderência pelo coeficiente de eficiência de Nash-Sutcliffe dos valores entre as três curvas apontou índices superiores a 0,999 entre todas as comparações entre si.

Para os hidrogramas selecionados entre 1974 e 1982, foi adotada a curva-chave apresentada na Eq. 10 (LIBOS, 2008).

$$
\mathrm{Q}=42,62758(\mathrm{NA}+1,01)^{1,75932} \quad \text { Eq. } 10
$$

Para os hidrogramas entre 1987 e 1989, de acordo com a Eq. 11 (LIBOS, 2008).

$$
\mathrm{Q}=30,736028(\mathrm{NA}+1,72)^{1,92953}
$$

E para os hidrogramas entre 1995 e 2006 foi adotada a regra da Eq. 12, já que esta é utilizada para representar a curva-chave de Cuiabá por Eletrobrás Furnas desde o início das operações da usina. 


$$
\begin{aligned}
& \mathrm{Q}=78,0306(\mathrm{NA}+1,17)^{1,5618} \text { se }-0,30 \mathrm{~m}<\mathrm{NA}<2,64 \mathrm{~m} ; \\
& \mathrm{Q}=59,975(\mathrm{NA}+1,56)^{1,6391} \text { se } \mathrm{NA} \geq 2,64 \mathrm{~m}
\end{aligned}
$$

Sendo:

$$
\mathrm{Q}=\operatorname{vazão}\left[\mathrm{m}^{3} / \mathrm{s}\right]
$$

$\mathrm{NA}=$ nível de água lido em régua linimétrica $[\mathrm{m}]$.

\subsection{Dados geométricos}

Conforme verificado na literatura, a recomendação geral para alimentação das informações topobatimétricas no corrente sistema fluvial é de seções topobatimétricas do canal fluvial espaçadas em no máximo a cada $4.000 \mathrm{~m}$, ou, aproximadamente 20 vezes a largura do rio principal (SAMUELS, 1990; FCTH, 2003). Ao considerar a dificuldade para obtenção desses resultados em campo, a distância média entre as seções neste trabalho foi de aproximadamente $20.000 \mathrm{~m}$. Para discutir este problema, entra em questão a representação realística e a viabilidade da execução do modelo, levantada por Beven (2001) e Hunter et. al. (2007). Dificuldades como essas são inevitáveis na aplicação de quaisquer modelos, especialmente em situações que visam representar condições naturais, como as características hidráulicas de um sistema fluvial.

Tendo esses fatores em conta, os dados geométricos das seções de interesse foram obtidos por meio de medições topobatimétricas realizadas nos meses de dezembro de 2009 e janeiro de 2010, a princípio, especificamente para esta pesquisa. Para tanto, houve financiamento do PROCAD - Programa Nacional de Cooperação Acadêmica - entre os cursos de pós-graduação do Programa de Recursos Hídricos, do Instituto de Ciências Exatas e da Terra, da Universidade Federal de Mato Grosso, campus de Cuiabá, e o Programa de Hidráulica e Saneamento da Escola de Engenharia de São Carlos da Universidade de São Paulo. Foram medidas 16 seções entre a estação fluviométrica da UHE Manso e o município de Santo Antônio de Leverger, ao longo de $330 \mathrm{~km}$. Quatro das seções se localizam no rio Manso e 12 no rio Cuiabá. As identificações das seções são apresentadas na Tabela 7, enquanto sua localização é ilustrada no APÊNDICE $\mathrm{C}$ e os resultados das medições topobatimétricas nos quadros do ANEXO B. 
Tabela 7 - Seções topobatimétricas nos rios Manso e Cuiabá

\begin{tabular}{|c|c|c|c|c|c|c|c|c|c|}
\hline Ponto & Nome & Rio & $\begin{array}{l}\text { Dist entre } \\
\text { seções } \\
(\mathbf{k m})\end{array}$ & Município & $\begin{array}{l}\text { Coordenada } \\
\text { Geográfica da RN } \\
\text { (GMS) }\end{array}$ & $\begin{array}{l}\text { Coordenada } \\
\text { Geográfica da RN } \\
\text { (UTM) }\end{array}$ & $\begin{array}{l}\text { Altitude } \\
\text { elipsoidal } \\
\text { da } R \mathbf{N}(\mathbf{m})\end{array}$ & $\begin{array}{l}\text { Ondulação } \\
\text { geoidal (m) - } \\
\text { MapGeo } 2004\end{array}$ & $\begin{array}{l}\text { Altitude } \\
\text { ortométrica da } \\
\text { RN (m) }\end{array}$ \\
\hline 1 & $\begin{array}{l}\text { Jusante ponte } \\
\text { UHE Manso* }\end{array}$ & Manso & - & $\begin{array}{l}\text { Chapada dos } \\
\text { Guimarães }\end{array}$ & $\begin{array}{l}\text { S } 14^{\circ} 52^{\prime} 03,6069^{\prime \prime} \mathrm{W} \\
55^{\circ} 48^{\prime} 01,4741^{\prime \prime}\end{array}$ & $\begin{array}{l}E(X): 629.052,617 \\
N(Y): 8.355 .958,013\end{array}$ & 237,758 & 5,69 & 232,068 \\
\hline 2 & Faz. Raizama* & Manso & 14 & $\begin{array}{l}\text { Chapada dos } \\
\text { Guimarães }\end{array}$ & $\begin{array}{l}\mathrm{S} 14^{\circ} 50^{\prime} 37,6216^{\prime \prime} \mathrm{W} \\
55^{\circ} 51^{\prime} 20,2115^{\prime \prime}\end{array}$ & $\begin{array}{l}E(X): 623.126,477 \\
N(Y): 8.358 .631,396\end{array}$ & 234,438 & 5,71 & 228,728 \\
\hline 3 & $\begin{array}{l}\text { Ponte de } \\
\text { Madeira }\end{array}$ & Manso & 45 & Nobres & $\begin{array}{l}\mathrm{S} 14^{\circ} 48^{\prime} 45,4677^{\prime \prime} \mathrm{W} \\
56^{\circ} 06^{\prime} 47,2040^{\prime \prime}\end{array}$ & $\begin{array}{l}E(X): 595.433,258 \\
N(Y): 8.362 .203,308\end{array}$ & 208,483 & 6,07 & 202,413 \\
\hline 4 & $\begin{array}{l}\text { Montante à foz } \\
\text { do rio Manso }\end{array}$ & Manso & 24 & Rosário Oeste & $\begin{array}{l}\mathrm{S} 14^{\circ} 41^{\prime} 56,1433^{\prime \prime} \mathrm{W} \\
56^{\circ} 14^{\prime} 13,2463^{\prime \prime}\end{array}$ & $\begin{array}{l}E(X): 582.142,884 \\
N(Y): 8.374 .829,001\end{array}$ & 200,317 & 6,27 & 194,047 \\
\hline 5 & $\begin{array}{l}\text { Jusante à foz do } \\
\text { rio Manso }\end{array}$ & Cuiabá & 2 & Rosário Oeste & $\begin{array}{l}\mathrm{S} 14^{\circ} 41^{\prime} 44,6230^{\prime \prime} \mathrm{W} \\
56^{\circ} 15^{\prime} 04,1510^{\prime \prime}\end{array}$ & $\begin{array}{l}E(X): 580.621,653 \\
N(Y): 8.375 .188,059\end{array}$ & 204,576 & 6,32 & 198,256 \\
\hline 6 & $\begin{array}{l}\text { Pesqueiro } \\
\text { Coqueiro }\end{array}$ & Cuiabá & 17 & Nobres & $\begin{array}{l}\mathrm{S} 14^{\circ} 45^{\prime} 08,4374^{\prime \prime} \mathrm{W} \\
56^{\circ} 19^{\prime} 38,7228^{\prime \prime}\end{array}$ & $\begin{array}{l}E(X): 572.391,316 \\
N(Y): 8.368 .951,770\end{array}$ & 200,212 & 6,50 & 193,712 \\
\hline 7 & Rosário Oeste* & Cuiabá & 33 & Rosário Oeste & $\begin{array}{l}\mathrm{S} 14^{\circ} 50^{\prime} 00,3786^{\prime \prime} \mathrm{W} \\
56^{\circ} 24^{\prime} 50,1293^{\prime \prime}\end{array}$ & $\begin{array}{l}E(X): 563.057,157 \\
N(Y): 8.360 .008,090\end{array}$ & 196,051 & 6,64 & 189,411 \\
\hline 8 & $\begin{array}{l}\text { Porto } \\
\text { Cachoeirinha }\end{array}$ & Cuiabá & 48 & Cuiabá & $\begin{array}{l}\text { S } 15^{\circ} 03^{\prime} 16,5134^{\prime \prime} \mathrm{W} \\
56^{\circ} 26^{\prime} 36,9405^{\prime \prime}\end{array}$ & $\begin{array}{l}E(X): 559.803,568 \\
N(Y): 8.335 .555,255\end{array}$ & 185,471 & 6,59 & 178,881 \\
\hline 9 & Acorizal* & Cuiabá & 35 & Acorizal & $\begin{array}{l}\text { S } 15^{\circ} 12^{\prime} 12,6730^{\prime \prime} \mathrm{W} \\
56^{\circ} 22^{\prime} 01,7234^{\prime \prime}\end{array}$ & $\begin{array}{l}E(X): 567.973,262 \\
N(Y): 8.319 .059,311\end{array}$ & 177,070 & 6,71 & 170,360 \\
\hline 10 & $\begin{array}{l}\text { Nossa } \mathrm{Sr}^{\mathrm{a}} \mathrm{da} \\
\text { Guia }\end{array}$ & Cuiabá & 24 & Cuiabá & $\begin{array}{l}\mathrm{S} 15^{\circ} 21^{\prime} 36,4471 \mathrm{~W} \\
56^{\circ} 14^{\prime} 50,5346^{\prime \prime}\end{array}$ & $\begin{array}{l}E(X): 580.778,560 \\
N(Y): 8.301 .695,641\end{array}$ & 164,331 & 6,94 & 157,391 \\
\hline 11 & $\begin{array}{l}\text { Porto Bandeira } \\
\text { (Sucuri) }\end{array}$ & Cuiabá & 21 & Cuiabá & $\begin{array}{l}\mathrm{S} 15^{\circ} 30^{\prime} 24,3748^{\prime \prime} \mathrm{W} \\
56^{\circ} 11^{\prime} 00,5286^{\prime \prime}\end{array}$ & $\begin{array}{l}E(X): 587.574,699 \\
N(Y): 8.285 .448,899\end{array}$ & 161,990 & 7,17 & 154,820 \\
\hline 12 & $\begin{array}{l}\text { Passagem da } \\
\text { Conceição }\end{array}$ & Cuiabá & 11 & Várzea Grande & $\begin{array}{l}\text { S } 15^{\circ} 33^{\prime} 58,1927^{\prime \prime} \mathrm{W} \\
56^{\circ} 08^{\prime} 30,6934^{\prime \prime}\end{array}$ & $\begin{array}{l}E(X): 592.012,610 \\
N(Y): 8.278 .861,259\end{array}$ & 161,868 & 7,25 & 154,618 \\
\hline
\end{tabular}

(Continua) 
(Continuação)

\begin{tabular}{|c|c|c|c|c|c|c|c|c|c|}
\hline Ponto & Nome & Rio & $\begin{array}{l}\text { Dist. entre } \\
\text { seções } \\
(\mathbf{k m})\end{array}$ & Município & $\begin{array}{l}\text { Coordenada } \\
\text { Geográfica da RN } \\
(\text { GMS })\end{array}$ & $\begin{array}{l}\text { Coordenada } \\
\text { Geográfica da RN } \\
\text { (UTM) }\end{array}$ & $\begin{array}{l}\text { Altitude } \\
\text { elipsoidal } \\
\text { da } \mathbf{R N}(\mathbf{m})\end{array}$ & $\begin{array}{l}\text { Ondulação } \\
\text { geoidal (m) - } \\
\text { MapGeo } 2004\end{array}$ & $\begin{array}{l}\text { Altitude } \\
\text { ortométrica da } \\
\text { RN (m) }\end{array}$ \\
\hline 13 & Cuiabá* & Cuiabá & 11 & Cuiabá & $\begin{array}{l}\mathrm{S} 15^{\circ} 37^{\prime} 12,9954^{\prime \prime} \mathrm{W} \\
56^{\circ} 06^{\prime} 51,0787^{\prime \prime}\end{array}$ & $\begin{array}{l}E(X): 594.954,880 \\
N(Y): 8.272 .863,174\end{array}$ & 156,092 & 7,33 & 148,762 \\
\hline 14 & Bom Sucesso & Cuiabá & 19 & Cuiabá & $\begin{array}{l}\mathrm{S} 15^{\circ} 43^{\prime} 12,8109^{\prime \prime} \mathrm{W} \\
56^{\circ} 06^{\prime} 17,0115^{\prime \prime}\end{array}$ & $\begin{array}{l}E(X): 595.922,683 \\
N(Y): 8.261 .802,292\end{array}$ & 156,908 & 7,50 & 149,408 \\
\hline 15 & Praia Grande & Cuiabá & 9 & Cuiabá & $\begin{array}{l}\mathrm{S} 15^{\circ} 45^{\prime} 33,4073^{\prime \prime} \mathrm{W} \\
56^{\circ} 08^{\prime} 43,4406^{\prime \prime}\end{array}$ & $\begin{array}{l}E(X): 591.546,890 \\
N(Y): 8.257 .500,005\end{array}$ & 156,192 & 7,64 & 148,552 \\
\hline 16 & $\begin{array}{l}\text { Santo Antônio } \\
\text { do Leverger* }\end{array}$ & Cuiabá & 17 & $\begin{array}{l}\text { Sto. Antônio } \\
\text { do Leverger }\end{array}$ & $\begin{array}{l}\mathrm{S} 15^{\circ} 52^{\prime} 11,4929^{\prime \prime} \mathrm{W} \\
56^{\circ} 04^{\prime} 35,9582^{\prime \prime}\end{array}$ & $\mathrm{N}(\mathrm{Y}): 8.245 .236,102$ & 152,238 & 7,72 & 144,518 \\
\hline
\end{tabular}

*Estações fluviométricas 
A escolha das seções topobatimétricas seguiu uma escala de preferências. De início, foram selecionados locais onde já existem estações fluviométricas. A partir de então, procurou-se espaçar as seções equidistantemente e de modo a escolher locais representativos do canal fluvial. Por sua impossibilidade, devido à dificuldade para chegar a muitos locais, foram selecionados pontos acessíveis próximos aos desejados. Entre os principais motivos que inviabilizaram tais acessos citam-se a densa mata ciliar, os barrancos muito declivosos, a inexistência de estradas que permitissem chegar com os equipamentos necessários aos locais escolhidos e pontos situados em áreas particulares com entrada restrita.

A topobatimetria se caracteriza por medições topométricas do relevo, na parte seca, e batimétricas, que representam a topografia do fundo da área molhada do rio. Na execução da topometria, com a utilização de um nível topográfico, foram fixados pontos iniciais (PI) e finais (PF) para estabelecer as extremidades da seção, sendo um em cada margem. Os pontos foram instalados na parte mais alta da calha fluvial, ou seja, nos diques marginais, e a partir da qual se inicia a planície fluvial, de menor altitude e por onde o rio teria as suas águas extravasadas na ocorrência de um fenômeno de cheia muito intensa. Entre o PI e PF foi instalada ainda a referência de nível $(\mathrm{RN})$, onde o aparelho de GPS era posicionado para a extração das informações sobre a altitude elipsoidal e as coordenadas geográficas do ponto de referência da seção. Tais informações eram obtidas por meio da Rede Brasileira de Monitoramento Contínuo - RBMC, serviço de auxílio à obtenção de posicionamentos globais, fornecido pelo IBGE. A conversão para altitude ortométrica foi efetivada com a utilização do software MapGeo 2004, também disponibilizado pelo IBGE. Está integrado nesse programa um modelo de ondulação geoidal com resolução de dez minutos de arco e um sistema de interpolação dessas ondulações, que fornecem o valor da ondulação geoidal do RN. A subtração desse valor pela altitude elipsoidal registrada no RN resulta no valor da altitude ortométrica, referida aos sistemas de datum SAD 69 (South American Datum 1969).

O levantamento batimétrico foi realizado simultaneamente ao topométrico. Nele, um cabo graduado foi utilizado para a definição dos locais que o lastro desceria transversalmente ao rio (a cada cinco metros). O equipamento utilizado para a leitura da profundidade do rio foi o guincho fluviométrico, que garante precisão centimétrica. Utilizou-se também o ecobatímetro para assegurar que não houvesse modificações bruscas da profundidade durante a travessia. A batimetria acoplada à altimetria compunha o perfil do rio na seção. 



\section{CALIBRAÇÃO}

Na calibração do modelo CLiv, aferiram-se os resultados de vazões calculadas frente à alteração dos principais parâmetros para analisar sua sensibilidade no processamento do software em cada uma das 13 cheias selecionadas do rio Cuiabá (conforme Tabela 6 - Maiores cheias em Cuiabá com disponibilidade de vazão nas principais estações fluviométricas da BHC, na página 65) entre o período de julho de 1972 e dezembro de 2009. Entre os parâmetros comparados citam-se: coeficiente de perda local (ou $k$ local), número de pontos na tabela das características do cálculo, número de subdivisões por trecho, número máximo de iterações, coeficiente de implicidade temporal, coeficiente de rugosidade de Manning e vazão específica da área intermediária da bacia hidrográfica.

\subsection{Parâmetros de calibração}

O coeficiente de perda local, ou $k$ local, diz respeito à perda localizada no nó em função da existência de mudanças bruscas na geometria da seção, como estrangulamentos ou grandes mudanças da declividade. Sua variação não foi significativa na aplicação das simulações. Ao ter os seus valores alterados em alguns índices da escala entre 0,001 a 100, a diferença de vazões observadas e calculadas no hidrograma de resultados variou em grandeza de no máximo algumas dezenas de metros cúbicos por segundo. Houve leve tendência à redução dos picos com o aumento desse parâmetro, já que se trata de perda local da seção.

A alteração do número de pontos na tabela de características teve inexpressivo significado. Foram examinados os resultados produzidos com a adoção de alguns índices entre 2 e 200 e a diferença entre os hidrogramas foi menor que uma dezena de metros cúbicos por segundo nas situações extremas.

O número de subdivisões diz respeito à quantidade de seções intermediárias de cálculo a serem intercaladas em um trecho específico, com interpolação das características hidrogeométricas das seções topobatimétricas das extremidades deste trecho. O objetivo das subdivisões é melhorar a definição do comportamento da linha de água no trecho em questão. Foram comparados diversos valores entre 1 e 110 pontos, e a diferença entre os hidrogramas foi tão pequena quanto as alterações na tabela de características; apesar de que algumas vezes foi preciso um número mínimo para o início do cálculo, em geral a partir de 8 . Notou-se 
também que o tempo de processamento cresce significativamente com o aumento do número de subdivisões do trecho.

O número máximo de iterações corresponde ao limite de iterações para que seja atingida a precisão do cálculo do nível de água de uma seção topobatimétrica em função do nível de água da seção anterior. Caso a convergência não seja atingida até o número máximo estabelecido, o algoritmo prossegue para a próxima seção. O CLiv não encontrou problemas de convergência durante sua aplicação quando a tolerância máxima para o nível de água adotada foi igual a $0,05 \mathrm{~m}$ e para a vazão igual a $0,5 \mathrm{~m}^{3} \cdot \mathrm{s}^{-1}$. Esses valores são considerados de aceitável precisão para o corrente trabalho.

O coeficiente de implicidade temporal corresponde ao grau de implicidade do método numérico de resolução das equações de escoamento utilizado (método implícito pelo esquema de discretização temporal e espacial de Pressman). Seu valor pode ser o mínimo admissível contanto que não haja sobrecarga de fluxo do escoamento hidrodinâmico.

É válido ressaltar que a variação da vazão obtida com a mudança de valores dos parâmetros testados até então, cuja diferença máxima foi da ordem de algumas dezenas de metros cúbicos por segundo, não é de expressiva importância excepcionalmente na aplicação deste sistema fluvial, já que as cheias do rio principal estão na escala de milhares de metros cúbicos por segundo. Isso pode significar que as análises de sensibilidade dos mesmos parâmetros resultam em maior importância à precisão da simulação em bacias hidrográficas menores que a em estudo neste trabalho.

$\mathrm{O}$ coeficiente de Manning se mostrou de relativa importância no que diz respeito à calibração. Os testes de alteração da rugosidade provocaram mudança nas vazões calculadas pelo modelo em no máximo algumas centenas de metros cúbicos por segundo para os mesmos intervalos de tempo. Essa diferença é de certa maneira compatível com a escala de vazões do rio Cuiabá durante as maiores cheias, cujas grandezas são de poucos milhares de metros cúbicos por segundo, como já mencionado. Por se tratar de coeficiente de rugosidade no escoamento, a aplicação do modelo respondeu de modo que a adoção de maiores valores de Manning reduziu os picos dos hidrogramas, alargou suas bases e atrasou o tempo de translação da onda de cheia.

No CLiv, é fornecida a alternativa para fixação da vazão específica do curso de água dada em vazão por unidade de comprimento do rio principal, ou, [L.s $\left.\mathrm{s}^{-1} \cdot \mathrm{km}^{-1}\right]$. Sua determinação é importante na simulação por permitir computar a vazão incremental advinda 
mormente do escoamento superficial da bacia hidrográfica entre as estações fluviométricas de montante e jusante do sistema fluvial. Este valor deve ser único ao longo de todo o curso de água simulado, pois não há a opção de variação entre cada seção topobatimétrica. Assim, a vazão correspondente à área intermediária da BHC entre a UHE Manso e o município de Cuiabá pôde ser acrescida ao cálculo do escoamento hidrodinâmico do canal fluvial.

\subsection{Ajuste dos parâmetros}

Ponderando as alterações admissíveis no CLiv, os parâmetros capazes de modificar substancialmente os resultados calculados para que se aproximem dos observados foram a rugosidade de Manning e as vazões específicas da área intermediária da bacia para cada uma das 13 cheias selecionadas. Foi aceita a possibilidade de serem adotadas porcentagens das vazões específicas, tendo em vista a dificuldade para a sua precisa definição.

A vazão específica da área intermediária da BHC é tratada como um parâmetro de valor diferente a cada uma das 13 cheias selecionadas, mesmo que sua origem seja a variável vazão, no decorrer dos anos. Essas vazões específicas são, portanto, fixas em cada cheia, porém variam de uma ocorrência para outra.

O cálculo das vazões específicas foi realizado a partir da consideração de zonas de influência das estações fluviométricas. Essas zonas têm abrangências semelhantes às áreas das sub-bacias da BHC, porém não idênticas. Em razão dessa semelhança, a vazão específica por ora calculada - relativa à zona de influência da estação Cuiabá - foi designada vazão específica da sub-bacia do Médio Cuiabá, cuja simbologia é representada por Qespec.BMC. Conforme ilustrado na Figura 10, a zona de influência da estação Cuiabá tem início a partir das estações fluviométricas dos rios Manso e Cuiabazinho, e termina na estação localizada a jusante do sistema estudado, em Cuiabá. 


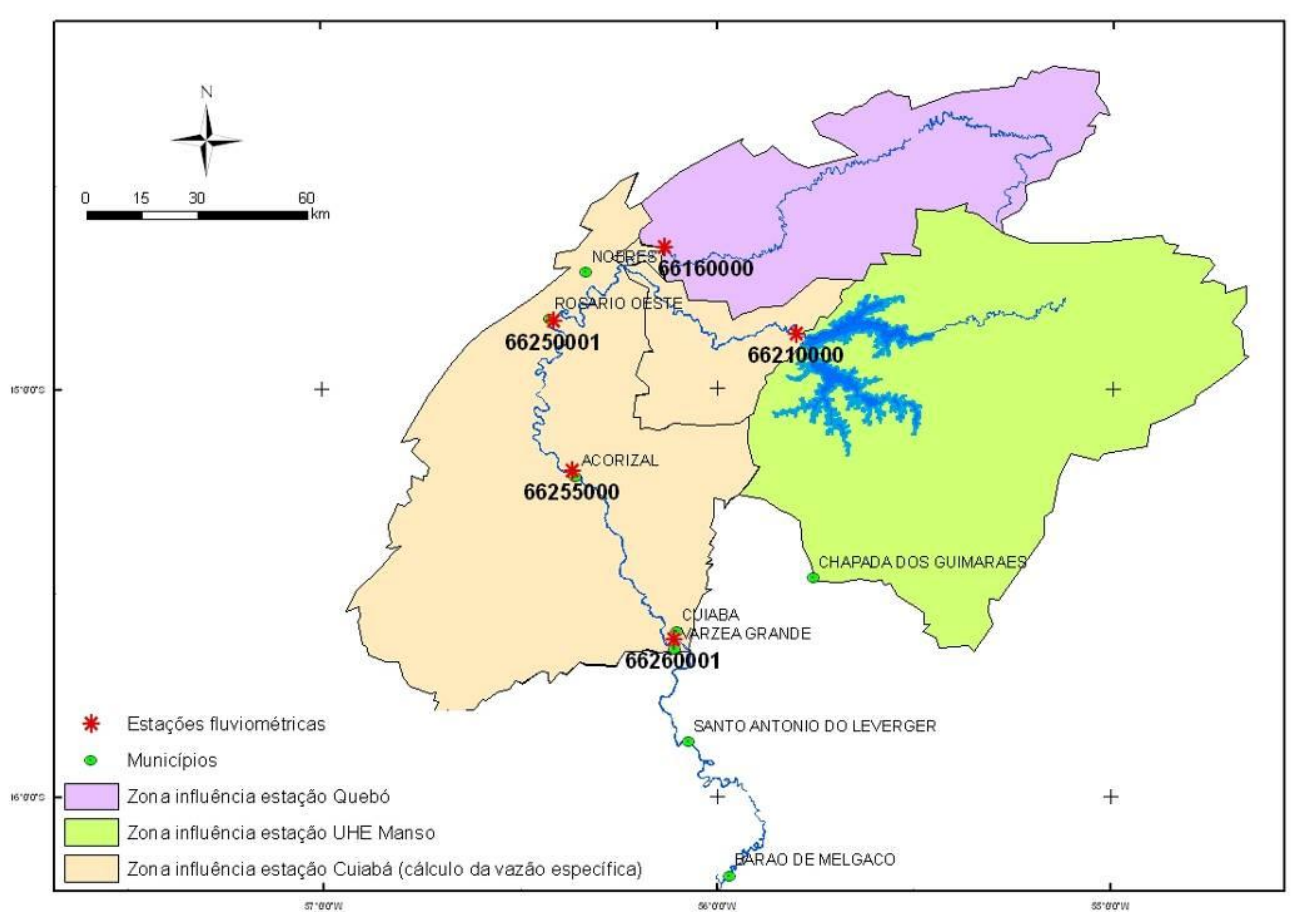

Figura 10 - Zonas de influência das estações fluviométricas da BHC

Para a determinação da vazão específica, o tempo de percurso das águas entre a estação fluviométrica da UHE Manso e Cuiabá foi considerado 48h; e o de Quebó até Cuiabá 24h, conforme Silva e Braga (2000). Assim, em posse dos hidrogramas das estações UHE Manso, Quebó e Cuiabá, as vazões específicas foram obtidas por meio da Eq. 13.

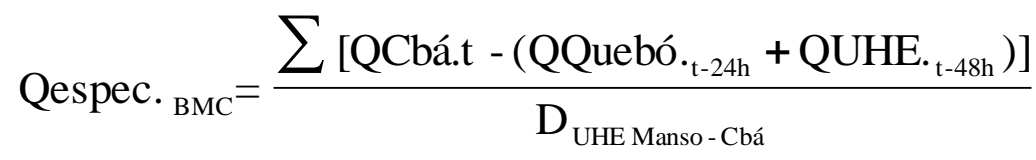
Eq. 13

Sendo:

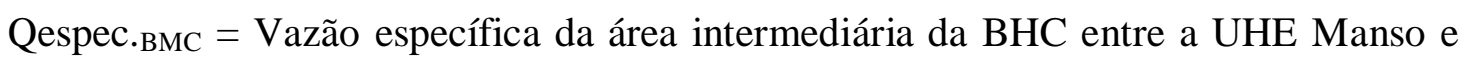
Cuiabá relativa à sub-bacia do Médio Cuiabá $\left[\mathrm{L}_{\mathrm{s}} \mathrm{s}^{-1} \cdot \mathrm{km}^{-1}\right]$;

Qcbá.t = Vazão registrada na estação fluviométrica Cuiabá no tempo " $\mathrm{t}$ " $\left[\mathrm{m}^{3} . \mathrm{s}^{-1}\right]$;

QQuebó.t-24h = Vazão da estação Quebó no dia anterior $(\mathrm{t}-24 \mathrm{~h})\left[\mathrm{m}^{3} . \mathrm{s}^{-1}\right]$;

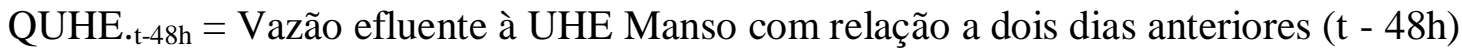
$\left[\mathrm{m}^{3} \cdot \mathrm{s}^{-1}\right]$;

D UHE Manso-Cbá = Distância entre as estações fluviométricas da UHE Manso e Cuiabá, pelo rio principal, equivalente a $285,58 \mathrm{~km}$. 
Para o cenário (iii), onde serão abordadas cheias de projeto com períodos de retorno críticos afluente ao reservatório de Manso, o cálculo da vazão específica recebeu uma variação da forma apresentada anteriormente pela (Eq. 13). Tal alternativa diz respeito à não subtração do hidrograma de cheia da estação Quebó. Isso significa generalizar a contribuição da sub-bacia do Alto Cuiabá, e estender a zona de influência da estação fluviométrica do município de Cuiabá, encontrando a Qespec.BMC+BAC. O raciocínio pode ser melhor compreendido pela Figura 11.

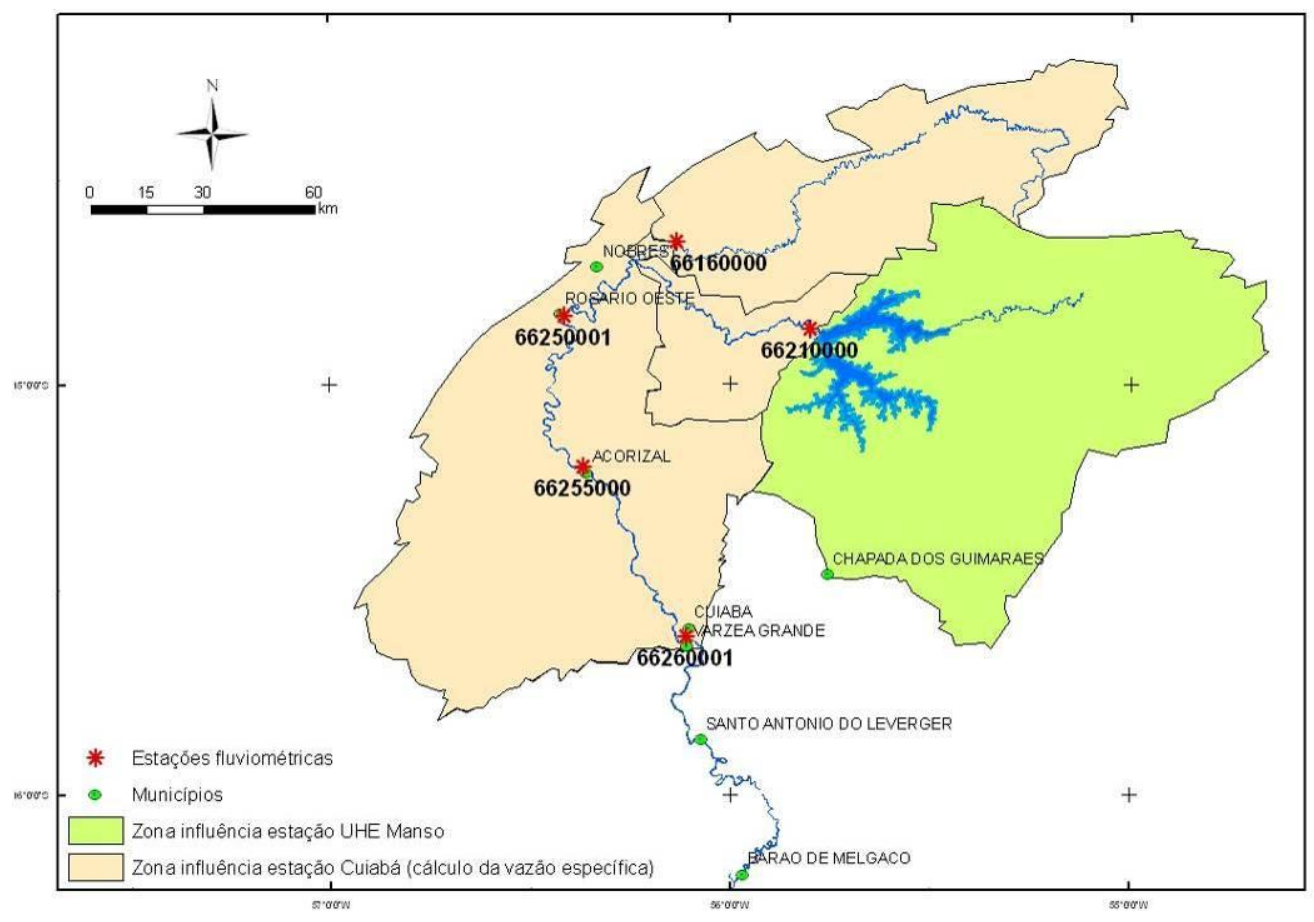

Figura 11 - Zonas de influência das estações fluviométricas da BHC para o cenário (iii)

O cálculo da vazão específica para o cenário (iii) foi realizado por meio da (Eq. 14). Depois de aplicada em cada uma das 13 cheias, a média aritmética foi adotada como o valor padrão para alimentação do modelo CLiv.

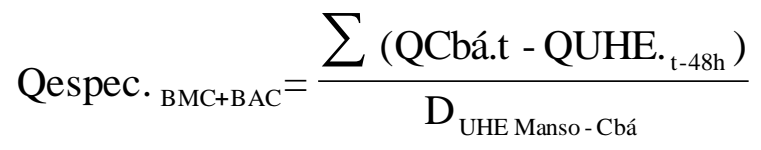

Sendo: 
Qespec BMC+BAC $_{\text {B }}=$ Vazão específica da área intermediária da BHC entre a UHE Manso e Cuiabá relativa à BMC e à BAC $\left[\right.$ L.s. $\left.{ }^{-1} \cdot \mathrm{km}^{-1}\right]$;

Qcbá.t = Vazão registrada na estação fluviométrica Cuiabá no tempo “ $\mathrm{t}$ ” $\left[\mathrm{m}^{3} . \mathrm{s}^{-1}\right]$;

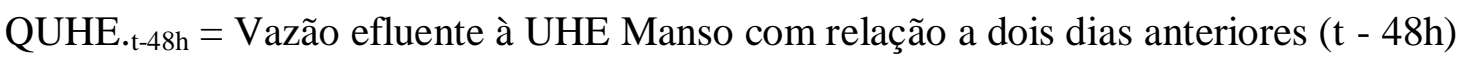
$\left[\mathrm{m}^{3} \cdot \mathrm{s}^{-1}\right]$;

D UHE Manso-Cbá = Distância entre as estações fluviométricas da UHE Manso e Cuiabá, pelo rio principal, equivalente a $285,58 \mathrm{~km}$.

Em decorrência da gama de possibilidades de cheias a que a bacia incremental entre o município de Cuiabá e o reservatório de Manso está submetida, três valores de vazões específicas foram processados nas simulações do cenário (iii). Assim, a partir da adoção da vazão específica média entre as 13 cheias selecionadas, pela (Eq. 14), duas outras opções metade desta média e o seu dobro - foram consideradas viáveis de acontecer em simultâneo às cheias críticas da sub-bacia do rio Manso. Essas foram as considerações relacionadas ao parâmetro definido como vazão específica da bacia intermediária.

Durante a calibração, a investigação para estabelecimento dos parâmetros do modelo matemático consistiu principalmente na variação das porcentagens das vazões específicas calculadas, e dos coeficientes de rugosidade dentro de limites aceitáveis para canais fluviais com as características da bacia estudada $(0,02$ a 0,06). Os demais parâmetros foram fixados em um único valor e não foram analisados, já que apresentaram insensibilidade na aplicação ao sistema fluvial.

Para a mensuração da aderência dos hidrogramas observados e calculados, quando submetidos aos parâmetros calibráveis, quatro análises principais foram empregadas:

(i) Comparação de picos entre os hidrogramas observados e calculados, por meio do erro porcentual da vazão de pico (EPVP);

(ii) Erro quadrático relativo médio (EQRM), que prioriza os valores máximos do hidrograma;

(iii) Coeficiente de eficiência Nash-Sutcliffe,

(iv) Comparação visual dos hidrogramas observados e calculados. 
Os parâmetros utilizados no modelo CLiv e os valores adotados para todas as simulações estão dispostos na Tabela 8.

\begin{tabular}{ll}
\multicolumn{2}{l}{ Tabela 8 - Parâmetros adotados no modelo CLiv } \\
\hline Parâmetro & Valor \\
\hline k local & 0,1 \\
$\mathrm{~N}^{\mathbf{o}}$ pontos na tabela das características & 12 \\
$\mathrm{~N}^{\mathbf{o}}$ subdivisões por trecho & 9 \\
$\mathrm{~N}^{\mathbf{o}}$ máximo de iterações & 3 \\
Coeficiente de implicidade temporal & 0,9 \\
Coeficiente de rugosidade de Manning & 0,06 \\
\hline
\end{tabular}

Em relação ao parâmetro rugosidade de Manning, foi admitido elevado coeficiente na BHC, equivalente a 0,06. Este índice é justificado por fatores como: vegetação de sarãs ao longo dos diques marginais; existência de praias fluviais conforme a redução da declividade da bacia; meandros; rochas emersas e imersas no meio do rio em alguns trechos. Além disso, em muitos locais há grande potencial de assoreamento e alguns espraiados, que tendem à elevação da concentração de sedimentos em suspensão, especialmente nas cheias, o que contribui para o aumento da rugosidade do canal.

Durante os testes de calibração foi estudado o fracionamento da vazão específica da BHC com taxas que variaram de $80 \%$ a $120 \%$ dos valores obtidos pela (Eq. 13), que diz respeito à vazão incremental em que foram desconsideradas as estações Quebó e UHE Manso. Essas iniciativas foram avaliadas como válidas devido à imprecisão na determinação das vazões específicas da área intermediária da BHC e também pelo fato de o modelo matemático não permitir incrementar essas vazões em cada trecho de influência das estações fluviométricas intermediárias. Mesmo que em algumas séries históricas essas frações tenham proporcionado melhores calibrações que a vazão específica equivalente a 100\%, essas "melhores calibrações" não apresentaram uniformidade na qualidade dos resultados em função da sua porcentagem. Portanto, fixou-se a vazão específica a ser adotada nas simulações equivalente a $100 \%$ do valor calculado para cada uma das cheias estudadas.

Tal imprecisão poderia ser superada por meio da modelagem hidrológica na bacia, que definiria com maior exatidão a vazão da área incremental entre a usina e os municípios 
estudados. Para tanto, são necessárias melhores informações hidrogeométricas que as disponíveis atualmente.

\subsection{Análise de desempenho da calibração}

A Tabela 9 diz respeito aos valores obtidos pelas análises matemáticas que serviram de base para a calibração do modelo - EPVP, EQRM, coeficiente de eficiência de NashSutcliffe - relativos às 13 cheias selecionadas quando comparados os hidrogramas calculados pelo CLiv em Cuiabá e os observados na estação fluviométrica de Cuiabá, correspondente a esta seção. Menores valores dos parâmetros de erro (EPVP e EQRM) indicam melhor calibração. Enquanto que quanto mais próximo o coeficiente de Nash-Sutcliffe estiver da unidade, também melhor é a calibração.

Tabela 9 - EPVP, EQRM e Nash-Sutcliffe entre os hidrogramas observados e calculados

\begin{tabular}{lllll}
\hline Cheia & Ano & $\begin{array}{l}\text { EPVP } \\
(\boldsymbol{\%})\end{array}$ & $\begin{array}{l}\text { EQRM } \\
(\boldsymbol{\%})\end{array}$ & $\begin{array}{l}\text { NASH- } \\
\text { SUTCLIFFE }\end{array}$ \\
\hline 1 & Mar/1974 & 6,42 & 5,20 & 0,56 \\
2 & Fev/1982 & 7,09 & 2,80 & 0,67 \\
\hline 3 & Mar/1982 & 2,73 & 5,20 & 0,46 \\
\hline 4 & Dez/1987 & 23,61 & 9,20 & 0,18 \\
\hline 5 & Jan/1988 & 12,68 & 12,60 & 0,75 \\
\hline 6 & Mar/1989 & 5,74 & 3,70 & 0,77 \\
7 & Jan/1995 & 0,87 & 8,90 & 0,79 \\
\hline 8 & Fev/1995 & 16,36 & 5,30 & 0,63 \\
\hline 9 & Mar/1996 & 3,42 & 4,90 & 0,66 \\
\hline 10 & Fev/1997 & 6,38 & 4,20 & 0,14 \\
11 & Mar/2002 & 12,80 & 11,20 & 0,65 \\
12 & Mar/2004 & 14,19 & 4,70 & 0,57 \\
13 & Abr/2006 & 11,06 & 1,30 & 0,54 \\
\hline
\end{tabular}

As Figuras 12 a 24 ilustram a comparação entre os hidrogramas observados (Qobs) e os calculados (Qcalc) sob as condições dos parâmetros adotados na calibração do CLiv em cada uma das 13 cheias. 


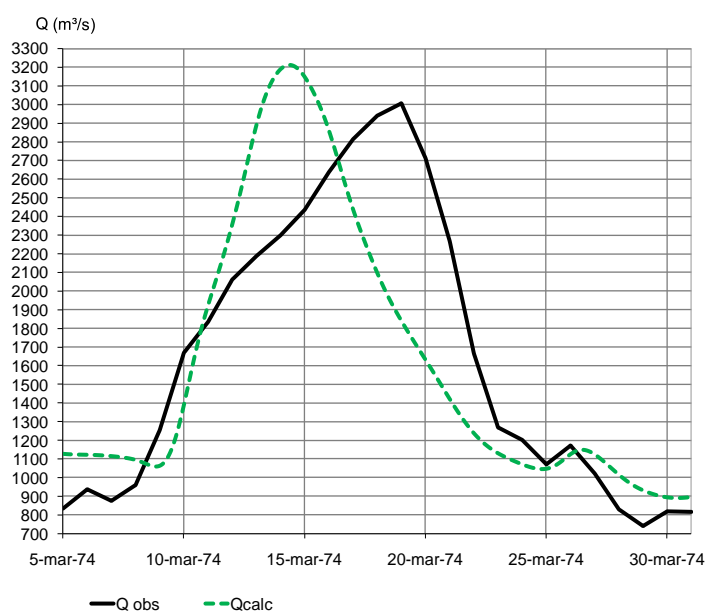

Figura 12 - Hidrogramas da cheia 1

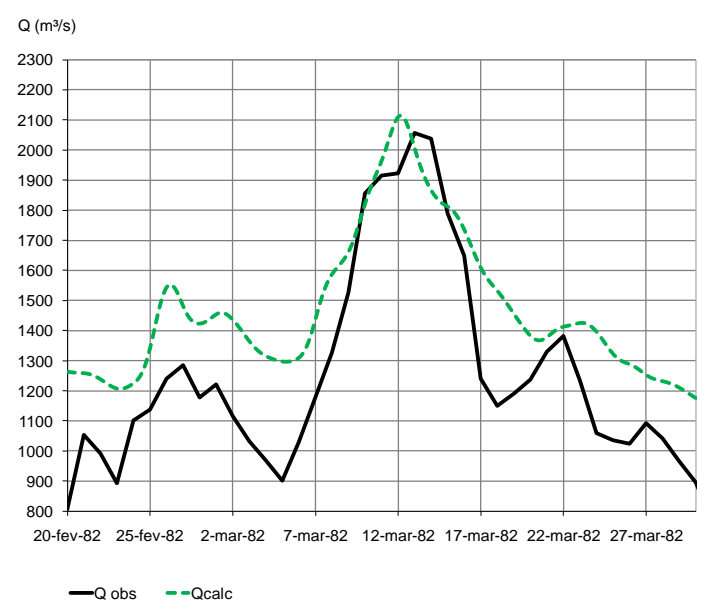

Figura 14 - Hidrogramas da cheia 3

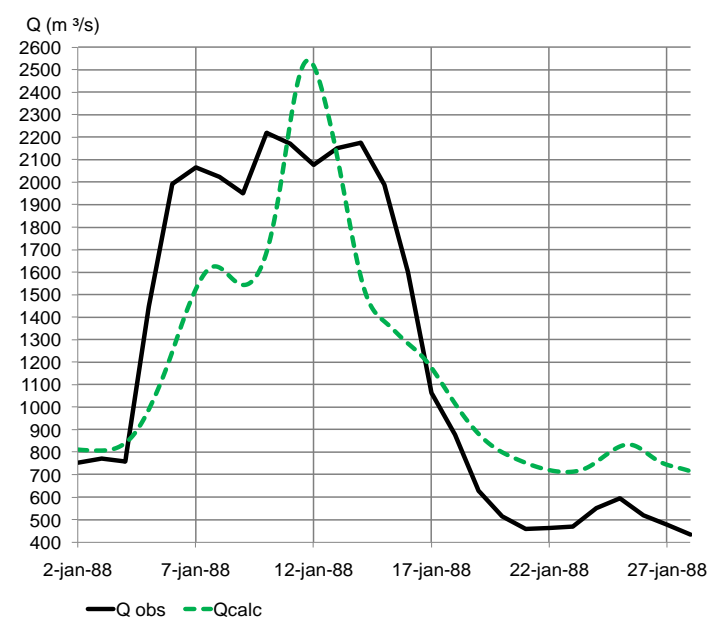

Figura 16 - Hidrogramas da cheia 5

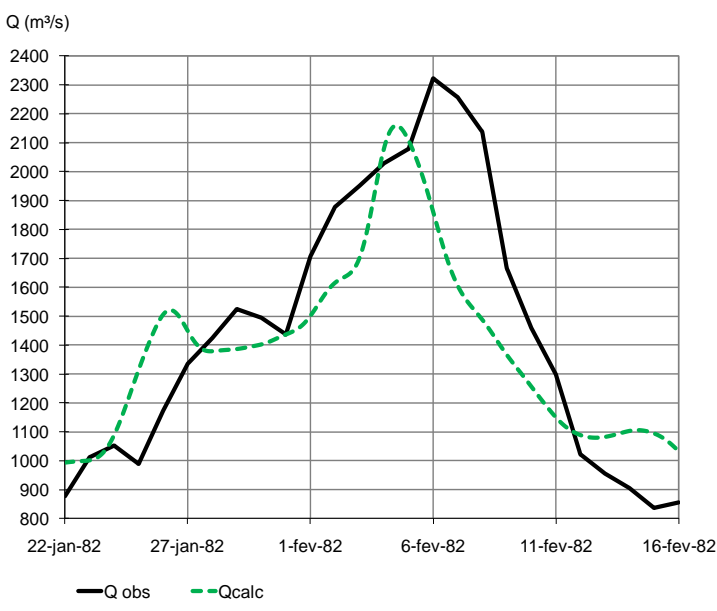

Figura 13 - Hidrogramas da cheia 2

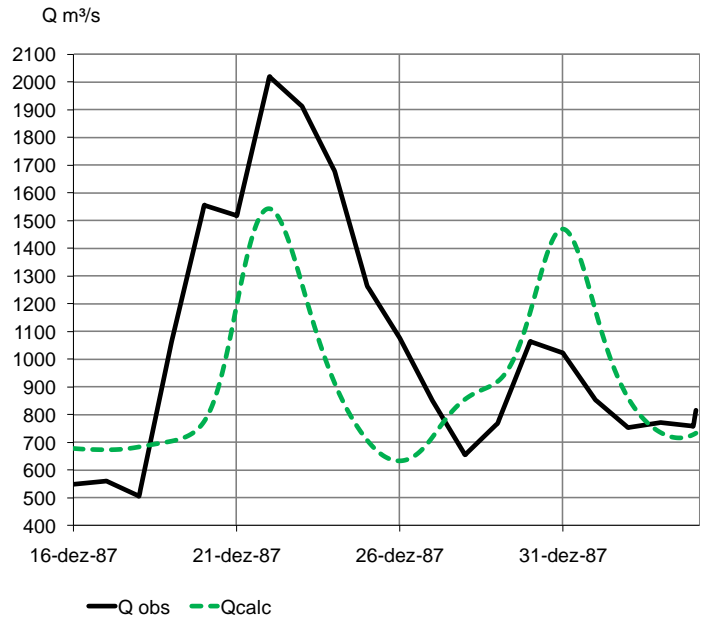

Figura 15 - Hidrogramas da cheia 4

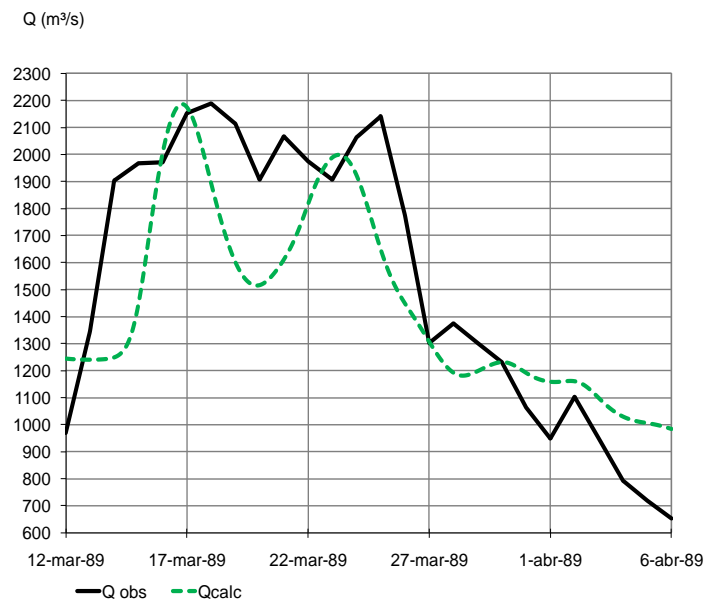

Figura 17 - Hidrogramas da cheia 6 


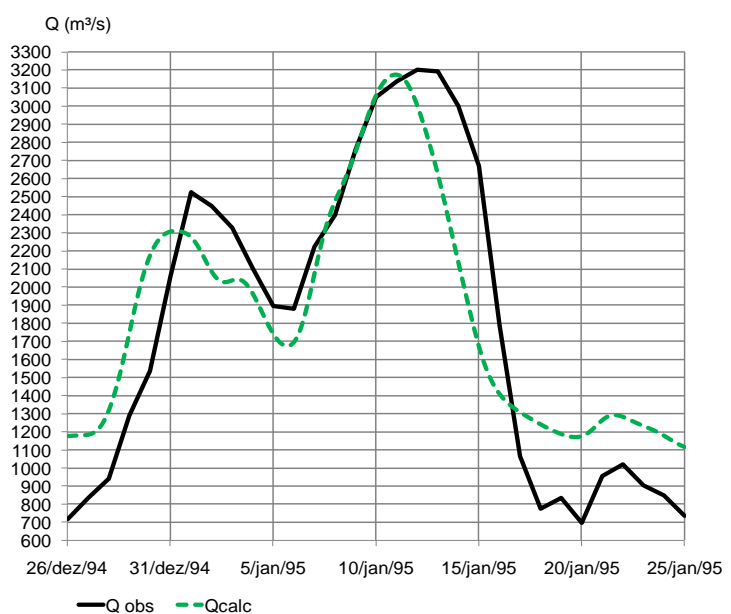

Figura 18 - Hidrogramas da cheia 7

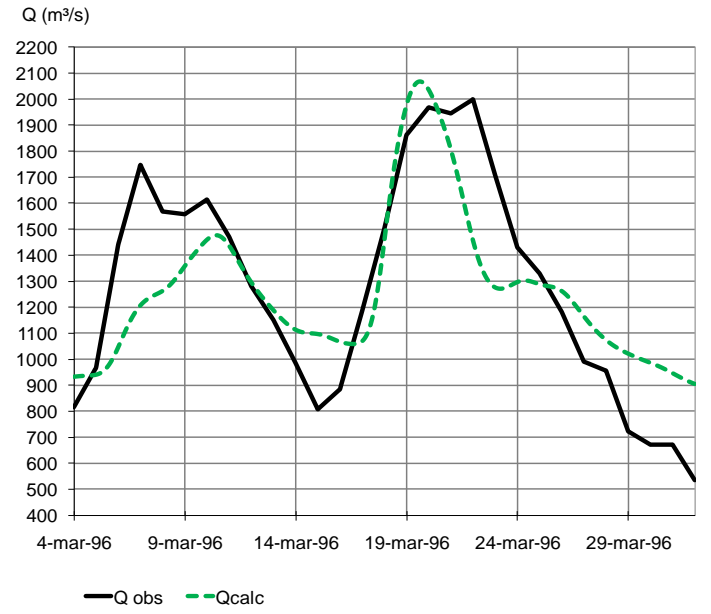

Figura 20 - Hidrogramas da cheia 9

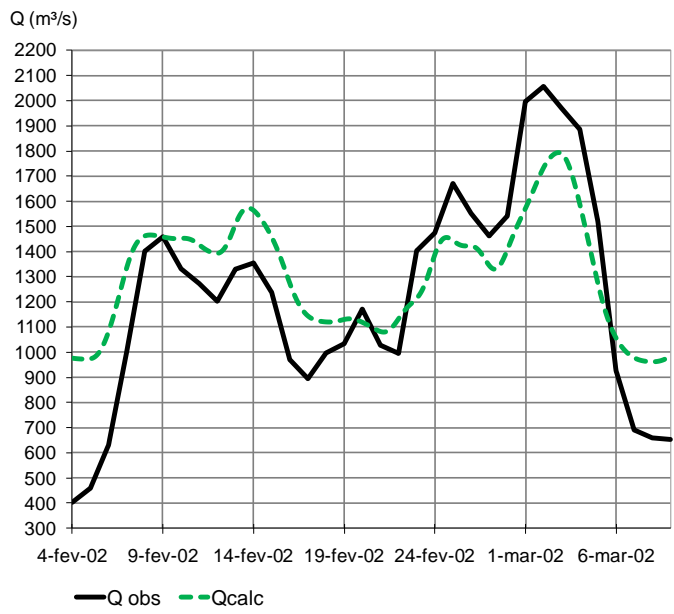

Figura 22 - Hidrogramas da cheia 11

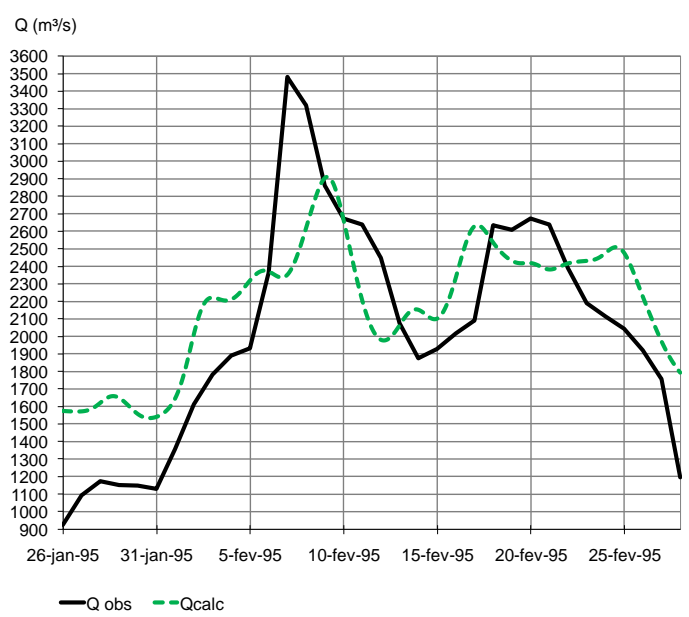

Figura 19 - Hidrogramas da cheia 8

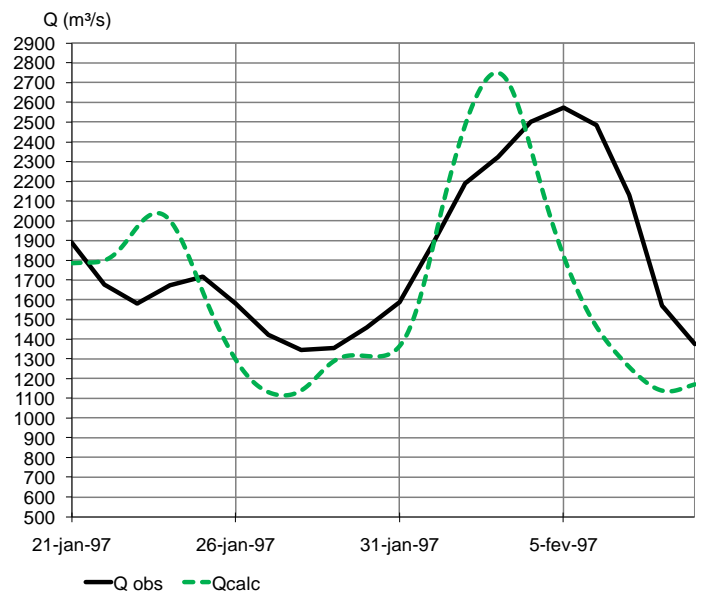

Figura 21 - Hidrogramas da cheia 10

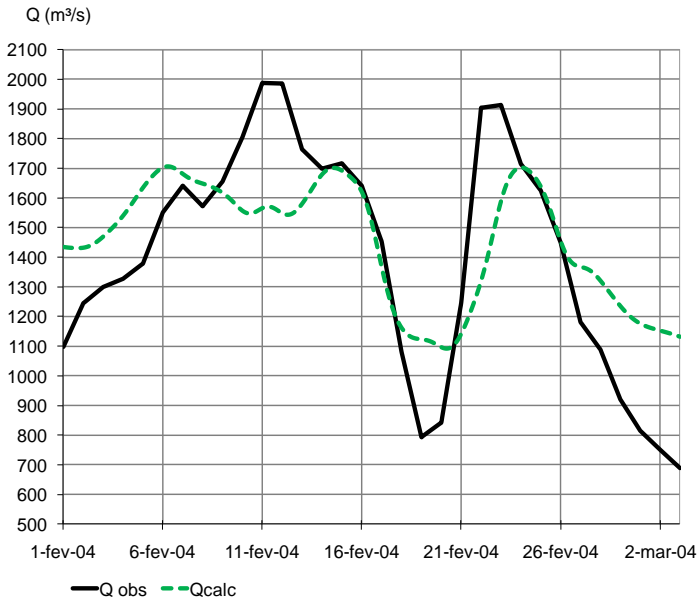

Figura 23 - Hidrogramas da cheia 12 


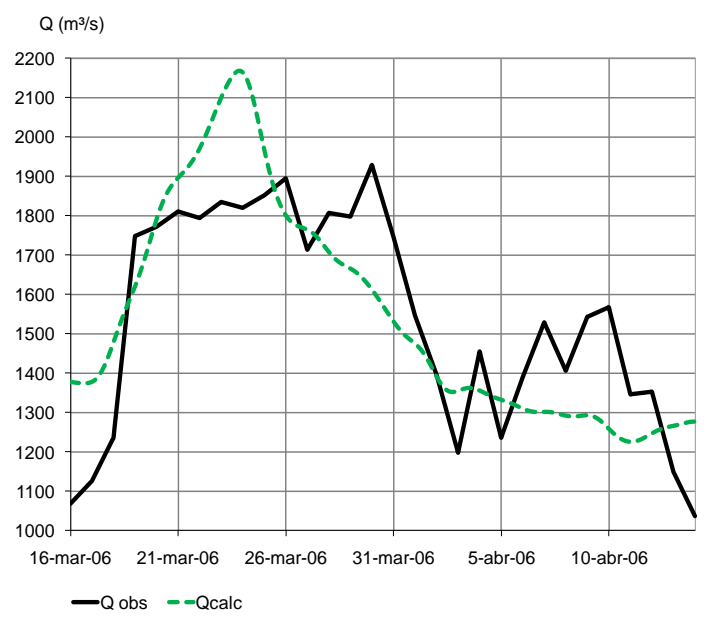

Figura 24 - Hidrogramas da cheia 13

A análise do erro porcentual da vazão de pico, do erro quadrático relativo médio, do coeficiente de eficiência Nash-Sutcliffe e das comparações visuais entre os hidrogramas permite afirmar, de modo geral, que o modelo reproduziu as vazões observadas de maneira satisfatória quando submetido aos parâmetros adotados (Tabela 8), ainda que em algumas situações não tenham sido muito bem reproduzidas.

O pior hidrograma calculado, quando comparado ao observado, foi o da cheia de número 4, ao passo que os melhores hidrogramas são os de número 3, 6, 7 e 9. Por vezes, os hidrogramas calculados foram muito próximos dos observados em determinados aspectos enquanto não em outros. Exemplo disso é o de número 8, em que o pico (EPVP) foi ruim apesar dos valores de EQRM e Nash-Sutcliffe serem relativamente bons. Houve casos, como nas curvas das cheias 2 e 13, que o EQRM foi bom, embora o EPVP e o coeficiente NashSutcliffe não tenham sido.

Vale lembrar que o erro quadrático relativo médio mede a aderência dos hidrogramas destacando as vazões máximas. Por esta razão, o EQRM foi de maior relevância durante a etapa da calibração.

As análises do EPVP, EQRM, coeficiente de eficiência de Nash-Sutcliffe e comparação visual entre hidrogramas foram realizadas tanto para a seção topobatimétrica em Cuiabá quanto para as intermediárias correspondentes aos municípios Rosário Oeste e Acorizal, embora só a primeira tenha sido apresentada. Tais comparações permitem afirmar que a reprodução dos hidrogramas nas seções intermediárias é muito melhor que na seção em 
Cuiabá, conforme já esperado. Isso confirma que o estudo de escoamento hidrodinâmico garante maior precisão quanto mais próximo o ponto de referência estiver da UHE Manso.

Neste sentido, houve melhora significativa em relação às cheias de número 4 e 13 , as quais haviam apresentado resultados de calibração relativamente ruins para Cuiabá. Como um exemplo, quanto à calibração da cheia de número 4 em Acorizal (Figura 25), o EPVP foi 2,02\%, o EQRM foi 4,20\% e o coeficiente de eficiência de Nash-Sutcliffe foi 0,66. Já os parâmetros de ajuste da cheia de número 13 em Rosário Oeste (Figura 26) apresentaram valores de EPVP igual a 6,22\%, EQRM a 4,4\% e coeficiente de eficiência de Nash-Sutcliffe a 0,80 .

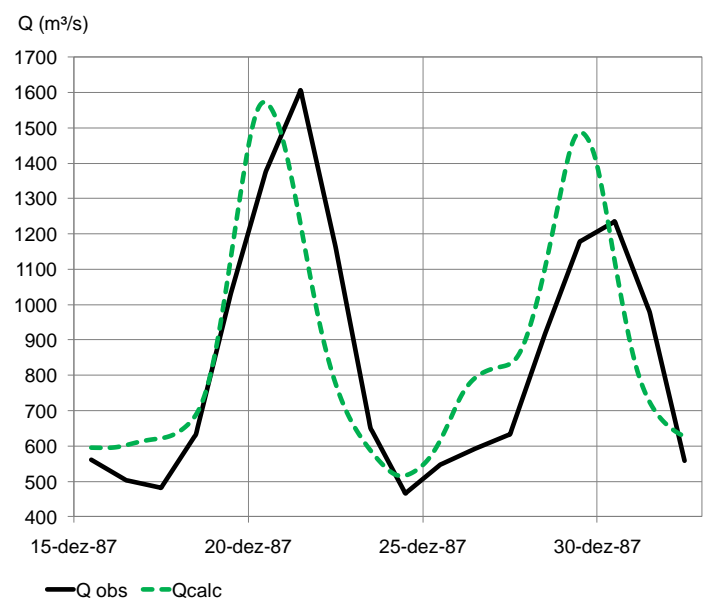

Figura 25 - Hidrograma da cheia 4, em Acorizal

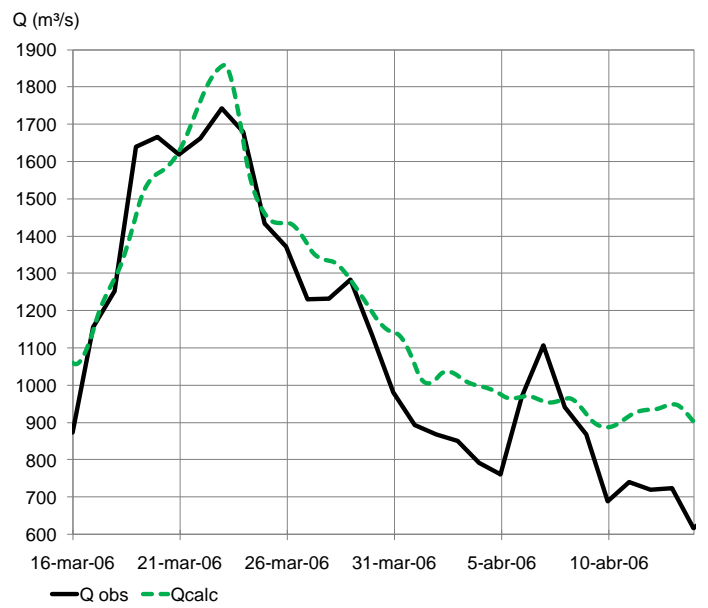

Figura 26 - Hidrograma da cheia 13, em Rosário Oeste 


\section{APRESENTAÇÃO DE RESULTADOS}

A princípio serão explanados os resultados dos dois tipos de vazões específicas da BHC até a estação fluviométrica de Cuiabá, o primeiro com exclusão dos hidrogramas das estações da UHE Manso e do rio Cuiabazinho - utilizadas para a calibração dos parâmetros e para a simulação dos cenários (i) e (ii) - e o segundo com exclusão apenas da estação fluviométrica da UHE Manso - utilizada no cenário (iii). Vale recordar que essas vazões não estão sob influência do reservatório da UHE Manso e, ao serem utilizadas para alimentar o modelo hidrodinâmico, representam a vazão da área incremental da bacia hidrográfica do rio Cuiabá.

Os resultados relativos ao amortecimento do reservatório são expostos imediatamente antes dos resultados da simulação hidrodinâmica para cada um dos casos nos três cenários. Ambos serão apresentados em forma de gráficos e seguidos por discussões. Os níveis de água obtidos pelo cálculo da propagação da onda de cheia serão confrontados com os níveis de segurança para a população das cidades de Rosário Oeste, Acorizal e Cuiabá em função dos limites de alerta, emergência e calamidade estabelecidos pela Superintendência de Defesa Civil do Estado de Mato Grosso (SUDEC/MT).

Cabe salientar que tais referências foram oficialmente estipuladas em termos de nível de água do rio Cuiabá conforme a régua fluviométrica em cada estação, convertidas neste trabalho para cotas ortométricas correspondentes a esses níveis para que haja coerência na apresentação dos resultados. Assim, adquire-se certa independência das medições linimétricas do rio em uma investigação sobre as possibilidades de cheia em determinado local da bacia.

A transformação para altitudes ortométricas foi realizada com base no datum, ou cotas zero das réguas fluviométricas, a saber: Rosário Oeste - 184,37 m, Acorizal - 164,83 m e Cuiabá - 139,36 m. A cota ortométrica de nível zero em Cuiabá foi informada pela SUCEC/MT, através da Planilha de controle fluviométrico, enquanto a dos demais municípios, por falta de informação suficiente dos órgãos competentes, foi extraída com base na comparação de níveis de água e das altitudes ortométricas medidas durante a campanha topobatimétrica. Os valores dos níveis de água e cotas ortométricas correspondentes aos limites de alerta, emergência e calamidade nos municípios de Rosário Oeste, Acorizal e Cuiabá estão apresentados na Tabela 10. 
Tabela 10 - Níveis de água e cotas ortométricas correspondentes aos limites de segurança em Rosário Oeste, Acorizal e Cuiabá

\begin{tabular}{llll}
\hline Município & $\begin{array}{l}\text { Limite de } \\
\text { segurança }\end{array}$ & $\begin{array}{l}\text { Nível de } \\
\text { água (m) }\end{array}$ & $\begin{array}{l}\text { Cota } \\
\text { ortométrica (m) }\end{array}$ \\
\hline Rosário Oeste & Alerta: & 7,40 & 191,77 \\
& Emergência: & 9,50 & 193,87 \\
& & & \\
Acorizal & Alerta: & 7,00 & 171,83 \\
& & & \\
Cuiabá & Alerta: & 8,50 & 147,86 \\
& Emergência: & 9,50 & 148,86 \\
& Calamidade: & 11,00 & 150,36 \\
\hline
\end{tabular}

Esses limites são o principal indicador de segurança para as comunidades da bacia do rio Cuiabá no tocante ao assunto das enchentes. A SUDEC/MT, por exemplo, utiliza os níveis linimétricos de Rosário Oeste para monitorar e acompanhar a dinâmica da cheia em favor da população a jusante, nos municípios de Cuiabá e Várzea Grande. É pertinente esclarecer que mesmo o alcance das cotas de alerta, ou até inferiores, pode significar inundação em alguns pontos habitados próximo ao rio, usualmente estabelecidos em área de inundação.

\subsection{Vazões específicas}

As vazões específicas que não foram contabilizadas nas estações das sub-bacias do Manso e do Alto Cuiabá, utilizadas para a calibração e simulação dos cenários (i) e (ii), calculadas pela (Eq. 13), da página 74, estão apresentadas na Tabela 11.

Tabela 11 - Vazão específica média da BHC com exceção das sub-bacias do Manso e do Alto Cuiabá

\begin{tabular}{|c|c|c|c|c|c|}
\hline $\begin{array}{l}\text { N. }{ }^{\circ} \\
\text { cheia }\end{array}$ & Período & $\begin{array}{l}\text { Qespec. }{ }_{\text {BMC }} \\
\left(\mathbf{L} . \mathbf{s}^{-1} \cdot \mathbf{k m}^{-1}\right)\end{array}$ & $\begin{array}{l}\text { N. } \\
\text { cheia }\end{array}$ & Período & $\begin{array}{l}\text { Qespec. }_{\text {BMC }} \\
\left(\text { L.s. }^{-1} \cdot \mathbf{k m}^{-1}\right)\end{array}$ \\
\hline 1 & 5 a 31 mar 1974 & $1.770,7$ & 8 & 26 jan a 28 fev 1995 & $3.797,6$ \\
\hline 2 & 22 jan a 16 fev 1982 & $1.605,9$ & 9 & 4 mar a 1 abr 1996 & $2.087,4$ \\
\hline 3 & $20 \mathrm{fev}$ a 31 mar 1982 & $2.936,6$ & 10 & 21 jan a 9 fev 1997 & $1.310,2$ \\
\hline 4 & $16 \operatorname{dez} 1987$ a 4 jan 1988 & 924,1 & 11 & 4 fev a 9 mar 2002 & $1.791,1$ \\
\hline 5 & 2 a 28 jan 1988 & $1.348,9$ & 12 & 1 fev a 3 mar 2004 & $1.885,7$ \\
\hline 6 & 12 mar a 6 abr 1989 & $2.131,2$ & 13 & 16 mar a 14 abr 2006 & $2.508,8$ \\
\hline 7 & $\begin{array}{l}26 \text { dez } 1994 \text { a } 25 \text { jan } \\
1995\end{array}$ & $2.367,8$ & & & \\
\hline
\end{tabular}


Como se pode observar, a menor vazão específica é $924,1 \mathrm{~L} \cdot \mathrm{s}^{-1} \cdot \mathrm{km}^{-1}$ e a maior é 3.797,6 L.s ${ }^{-1} \cdot \mathrm{km}^{-1}$, correspondentes às cheias $4 \mathrm{e} 8$, respectivamente. A média aritmética dessas vazões é $2.046,0 \mathrm{~L} \cdot \mathrm{s}^{-1} \cdot \mathrm{km}^{-1}$.

A partir dos resultados da Tabela 11, foi realizada uma análise para comparar as vazões específicas de contribuição relativas às zonas de influência das estações fluviométricas das subáreas Rosário Oeste, Acorizal e Cuiabá, independentes uma das outras. A finalidade desta análise foi averiguar possíveis relações entre as vazões específicas dessas subáreas e a qualidade na aderência das curvas de calibração. Cabe ressaltar que não foram encontrados valores de vazões da cheia de número 1, na subárea Rosário Oeste, pois não houve leitura dos níveis de água durante o pico da cheia. Os resultados dessa análise estão expostos no gráfico da Figura 27.

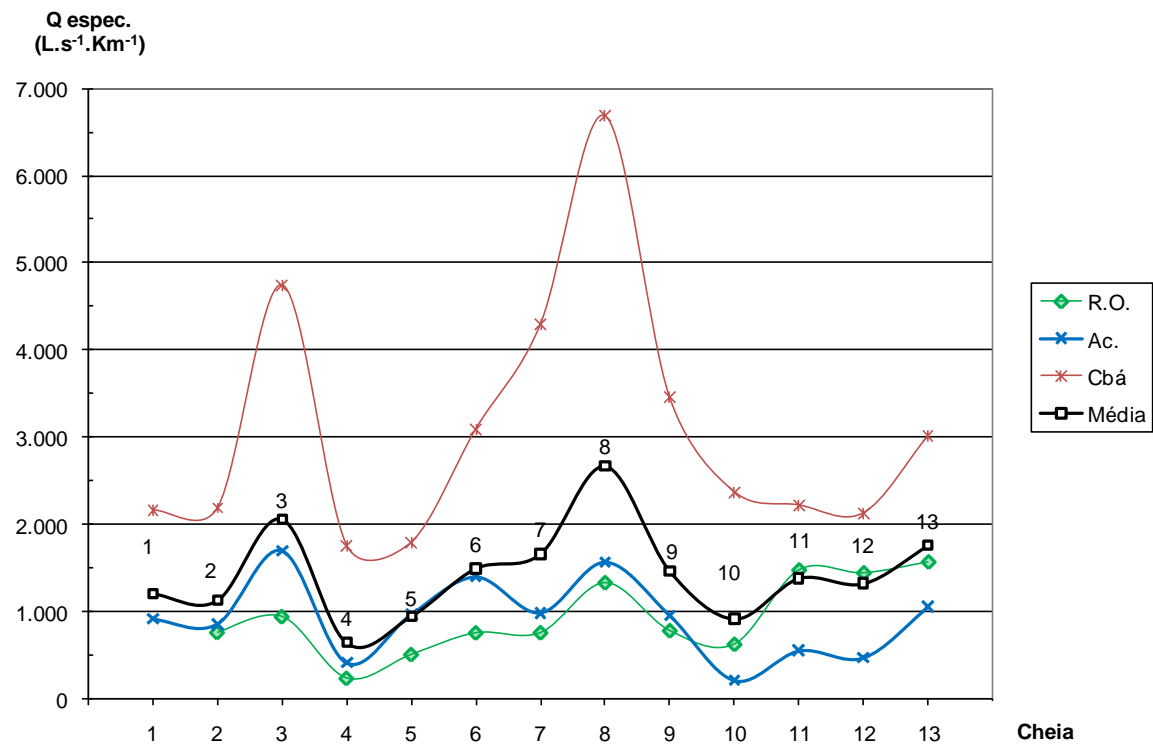

Figura 27 - Vazões específicas referentes às zonas de influência de cada estação fluviométrica para as 13 cheias selecionadas

É possível notar que as vazões específicas da subárea Rosário Oeste é similar às de Acorizal em quase todas as 13 cheias. Além disso, as vazões específicas destas duas subáreas são inferiores às de Cuiabá.

A hipótese das possíveis relações entre as vazões específicas sob influência das estações fluviométricas Rosário Oeste, Acorizal ou Cuiabá e a qualidade na aderência das curvas durante a calibração não foi confirmada, visto que, grosso modo, as proporções entre 
as vazões específicas são parecidas, o que não acontece com a qualidade das calibrações das cheias entre si. Assim como as vazões específicas das subáreas, também não foram encontradas quaisquer correlações entre a qualidade da reprodução de vazões e a forma dos hidrogramas observados.

Por não haver informações a respeito dos hidrogramas associados aos períodos de retorno críticos do rio Cuiabazinho, para que sejam carregados junto com os hidrogramas da sub-bacia do Manso no cenário (iii), outras vazões específicas foram calculadas, dessa vez sem a exclusão dos hidrogramas da sub-bacia do Alto Cuiabá. Assim, a contribuição desta sub-bacia é também considerada como parte da vazão da área incremental da BHC (conforme a Figura 11, da página 75). Automaticamente, a única sub-bacia que se tem pleno conhecimento dos valores de entrada de água passa a ser a do rio Manso, cujo controle é realizado em grande parte pelo APM Manso.

As vazões específicas arbitradas para o cenário (iii) e seus períodos correspondentes, relativos às 13 cheias selecionadas, tiveram por base os valores apresentados na Tabela 12 . A média aritmética é de $3.440,8 \mathrm{~L} \cdot \mathrm{s}^{-1} \cdot \mathrm{km}^{-1}$, e as variações estão compreendidas entre $1.658,7 \mathrm{e}$ $5.599,9 \mathrm{~L} . \mathrm{s}^{-1} \cdot \mathrm{km}^{-1}$, igualmente atinentes às cheias 4 e 8 .

Tabela 12 - Vazão específica média da BHC com exceção da sub-bacia do Manso

\begin{tabular}{|c|c|c|c|c|c|}
\hline $\begin{array}{l}\text { N. } \\
\text { cheia }\end{array}$ & Período & $\begin{array}{l}\text { Qespec. } \\
\text { BMC+BAC } \\
\left(\mathbf{L} . \mathbf{s}^{-1} \cdot \mathbf{k m}^{-1}\right)\end{array}$ & $\begin{array}{l}\text { N. }^{\circ} \\
\text { cheia }\end{array}$ & Período & $\begin{array}{l}\text { Qespec. } \\
\text { BMC+BAC } \\
\left(\mathbf{L} \cdot \mathbf{s}^{-1} \cdot \mathbf{k m}^{-1}\right)\end{array}$ \\
\hline 1 & 5 a 31 mar 1974 & $3.159,1$ & 8 & 26 jan a 28 fev 1995 & $5.599,9$ \\
\hline 2 & 22 jan a 16 fev 1982 & $2.860,5$ & 9 & 4 mar a 1 abr 1996 & $3.115,8$ \\
\hline 3 & 20 fev a 31 mar 1982 & $4.138,6$ & 10 & 21 jan a 9 fev 1997 & $2.322,7$ \\
\hline 4 & 16 dez 1987 a 4 jan 1988 & $1.658,7$ & 11 & 4 fev a 9 mar 2002 & $3.986,9$ \\
\hline 5 & 2 a 28 jan 1988 & $2.484,9$ & 12 & 1 fev a 3 mar 2004 & $3.978,4$ \\
\hline 6 & 12 mar a 6 abr 1989 & $2.943,4$ & 13 & 16 mar a 14 abr 2006 & $4.223,8$ \\
\hline 7 & $\begin{array}{l}26 \text { dez } 1994 \text { a } 25 \text { jan } \\
1995\end{array}$ & $4.258,3$ & & & \\
\hline
\end{tabular}

O valor adotado para a simulação do escoamento hidrodinâmico no cenário (iii) foi a média aritmética das vazões específicas. Além disso, para respaldar a variação hidrológica possível de ocorrer em uma bacia, e também por motivos de imprecisão das vazões críticas de contribuição intermediária, foram atribuídas duas outras variantes: o dobro e a metade dessa média. Portanto, as vazões específicas computadas para o referido cenário são as dispostas na Tabela 13. 


\begin{tabular}{ll}
\multicolumn{2}{l}{ Tabela 13 - Vazões específicas para o Cenário (iii) } \\
\hline Variantes & $\begin{array}{l}\text { Vazão específica } \\
\left(\mathbf{L . s}^{-1} \cdot \mathbf{k m}^{-1}\right)\end{array}$ \\
\hline Qespec. вMC+BAC & $3.440,8$ \\
2 x Qespec. BMC+BAC & $6.881,7$ \\
0,5 x Qespec. BMC+BAC & $1.720,4$ \\
\hline
\end{tabular}

A comparação das vazões específicas de cada cheia, conforme Tabela 12, com as vazões específicas menores e maiores adotadas para a simulação do cenário (iii), da Tabela 13, possibilita observar a proximidade dos valores mínimos, assim como a superioridade em cerca de $80 \%$ da vazão específica adotada em relação ao máximo das 13 cheias.

\subsection{Cenário (i)}

Neste cenário é suposta a inexistência do APM Manso nas cheias de número 11, 12 e 13, atinentes a 2002, 2004 e 2006. Com exceção da ocorrida em fevereiro de 2010, essas cheias foram as principais em Cuiabá desde o início das operações da UHE Manso. Apesar de o nível de água em 2010 ter sido maior, os dados necessários para a simulação não estão disponíveis até o momento, e por tal razão sua investigação não foi realizada. Cabe salientar que desde o funcionamento da UHE Manso não houve extravasamento da calha do rio Cuiabá nos três municípios estudados, embora o tenha havido em outras localidades a jusante. A investigação deste cenário visa averiguar qual a contribuição do reservatório na atenuação das cheias e se elas seriam suficientes para que os níveis de água não atingissem as cotas de segurança nas situações propostas.

A condição de contorno de montante aceita para essa operação foi o hidrograma de afluência no reservatório de Manso nos períodos analisados; e as vazões específicas foram as correspondentes às cheias de seus próprios anos, de acordo com a Tabela 11, equivalentes a $1.791 \mathrm{~L} . \mathrm{s}^{-1} \cdot \mathrm{km}^{-1}$ (para 2002), $1.886 \mathrm{~L} . \mathrm{s}^{-1} \cdot \mathrm{km}^{-1}$ (para 2004) e $2.509 \mathrm{~L} . \mathrm{s}^{-1} \cdot \mathrm{km}^{-1}$ (para 2006).

\subsubsection{Caso 2002}

As cheias deste ano consistiram em uma das menores entre as investigadas no presente estudo. O comparativo entre as vazões de entrada e saída do reservatório de Manso, demonstrando o amortecimento da cheia de 2002, é apresentado na Figura 28; enquanto as 
cotas ortométricas dos níveis de água observados na estação fluviométrica e calculados pelo modelo hidrodinâmico para os municípios de Rosário Oeste, Acorizal e Cuiabá, em paralelo com as cotas de referência de segurança do rio, são apresentados nas Figuras 29 a 31.

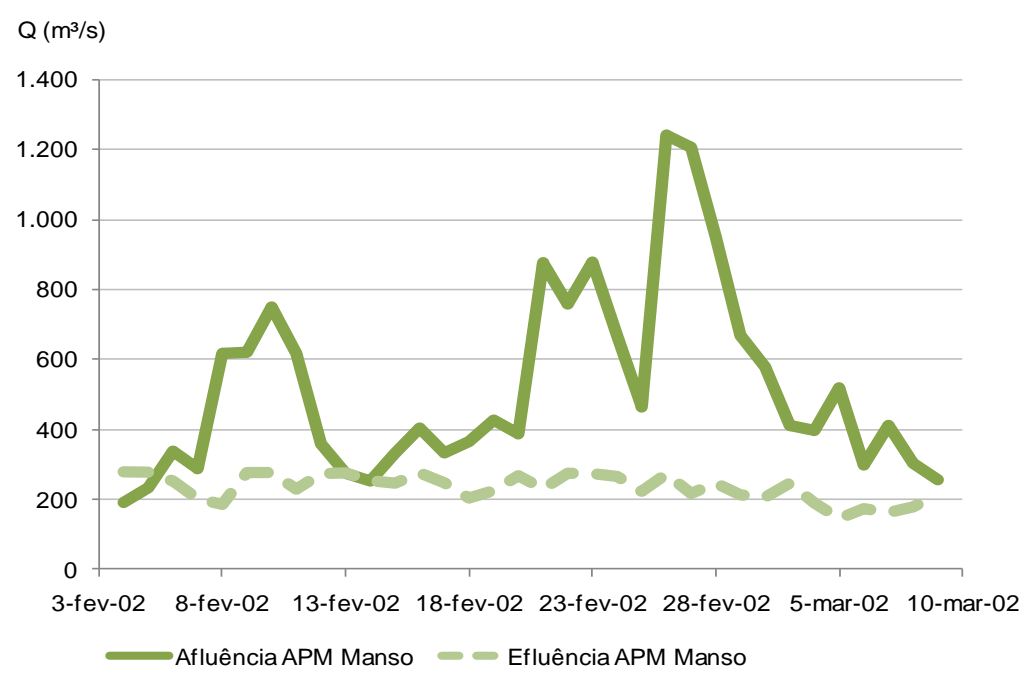

Figura 28 - Afluência e efluência no reservatório de Manso (2002)

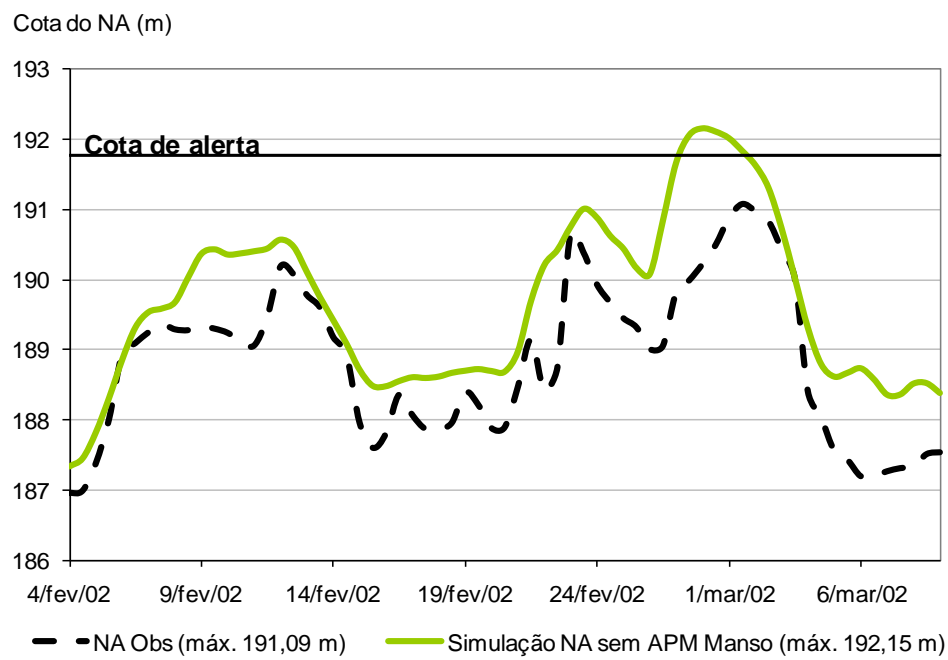

Figura 29 - Cotas de Rosário Oeste (2002) 


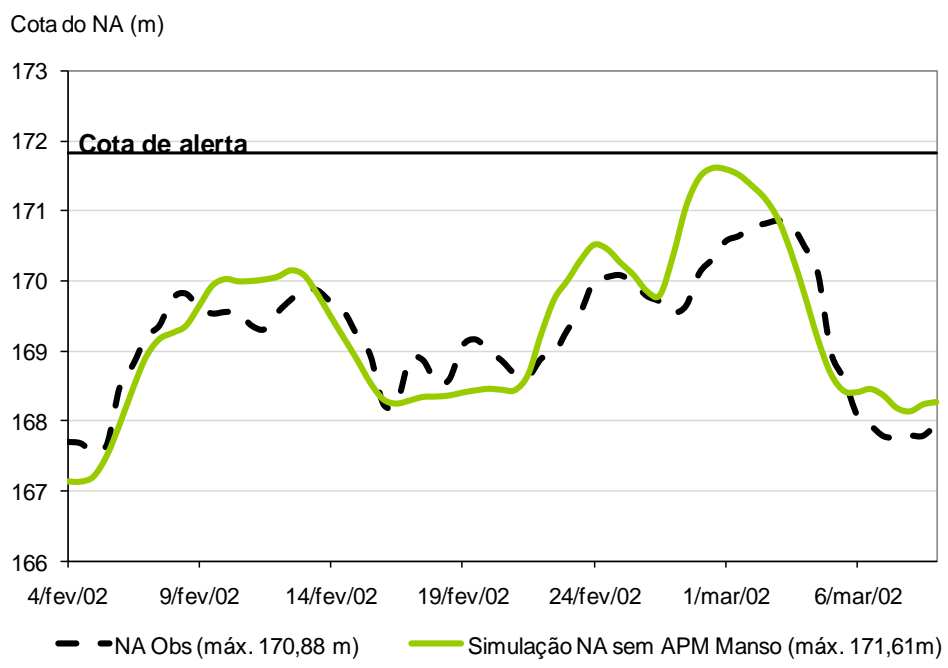

Figura 30 - Cotas de Acorizal (2002)

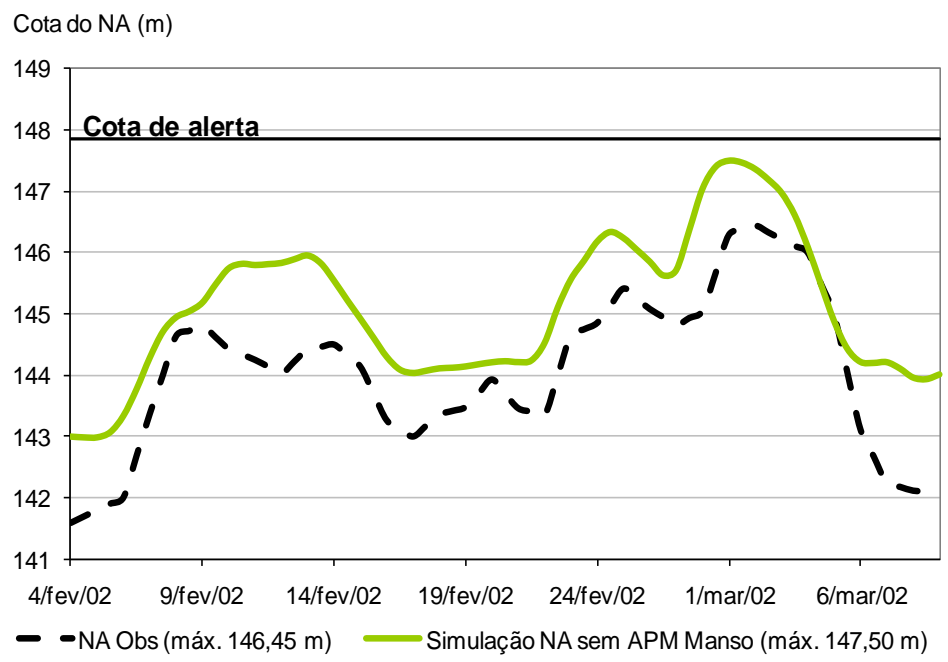

Figura 31 - Cotas de Cuiabá (2002)

A afluência máxima ao reservatório de Manso foi de $1.243 \mathrm{~m} 3 / \mathrm{s}$, enquanto a defluência máxima foi de $274 \mathrm{~m} 3 / \mathrm{s}$. Apesar da declaração da maior vazão defluente, é fato que o pico não existiu, pois a descarga observada se manteve de certa maneira constante.

Quanto às simulações hidrodinâmicas, os valores observados após o amortecimento do APM Manso estiveram ente 0,68 m abaixo da cota de alerta em Rosário Oeste e 1,41 m em Cuiabá. A simulação da inexistência do reservatório apontou que esse nível teria sido ultrapassado, durante curto período, em até 0,38 m no município de Rosário Oeste. Os níveis de água teriam se mantido pouco abaixo da cota de alerta nos municípios de Acorizal e Cuiabá. 


\subsubsection{Caso 2004}

A cheia de 2004 foi também de pequenas proporções, e na mesma escala que a de 2002. Os resultados do amortecimento e das cotas atingidas estão apresentados nas Figuras 32 a 35.

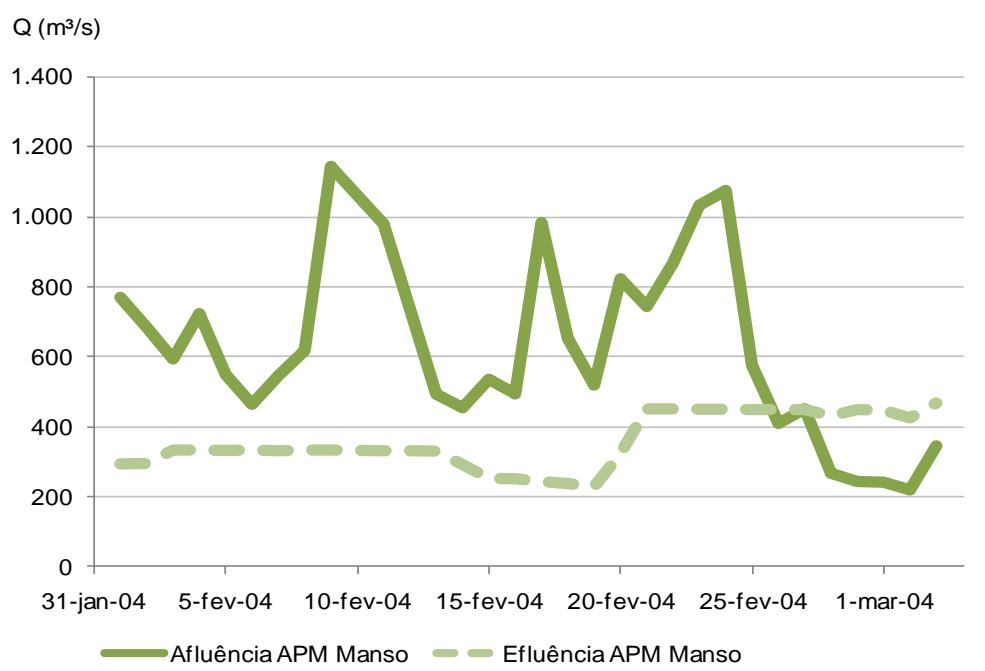

Figura 32 - Afluência e efluência no reservatório de Manso (2004)

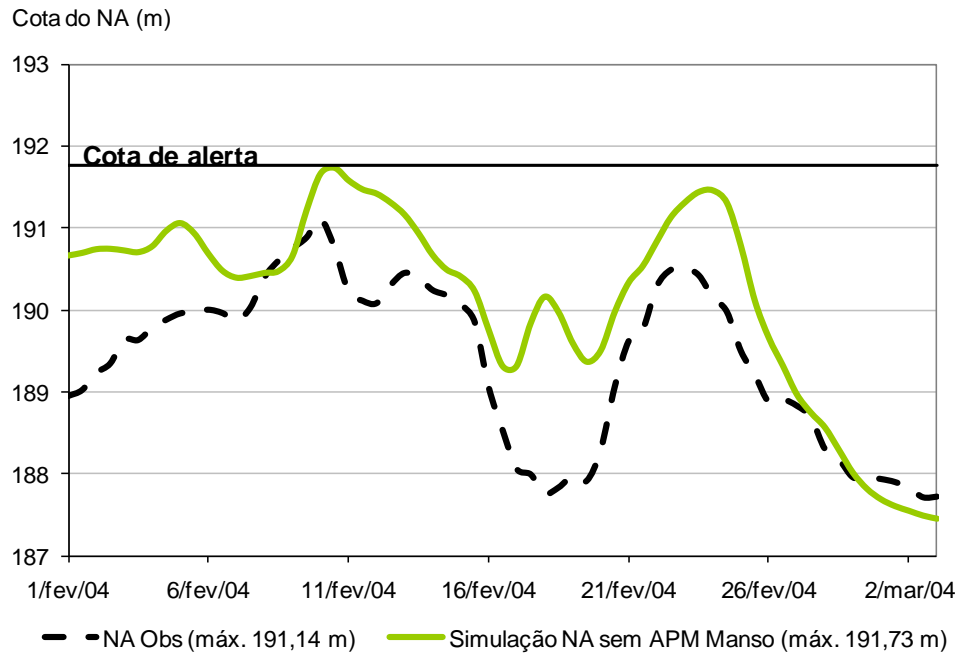

Figura 33 - Cotas de Rosário Oeste (2004) 


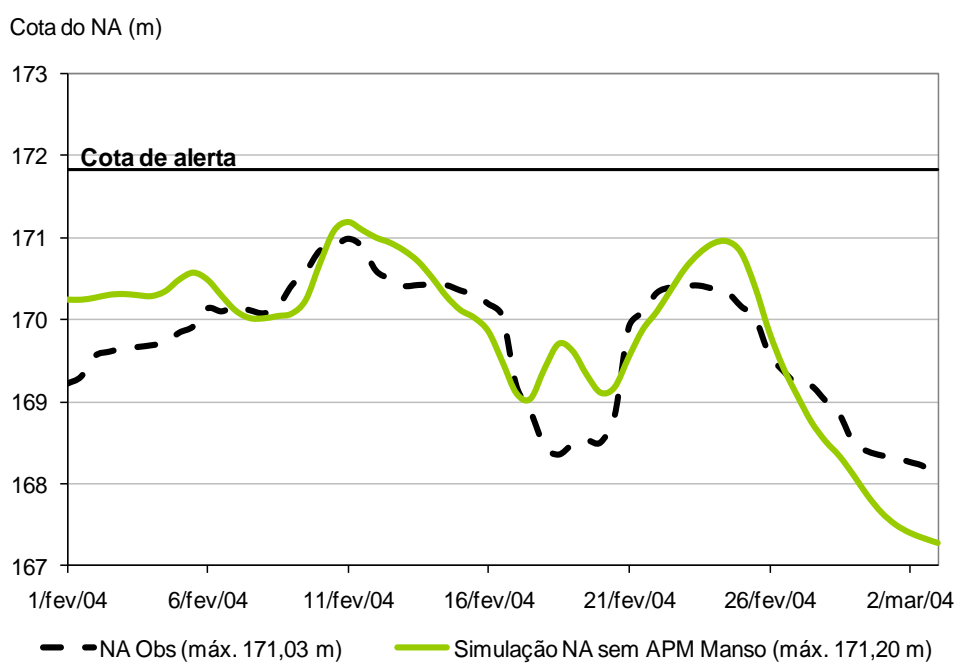

Figura 34 - Cotas de Acorizal (2004)

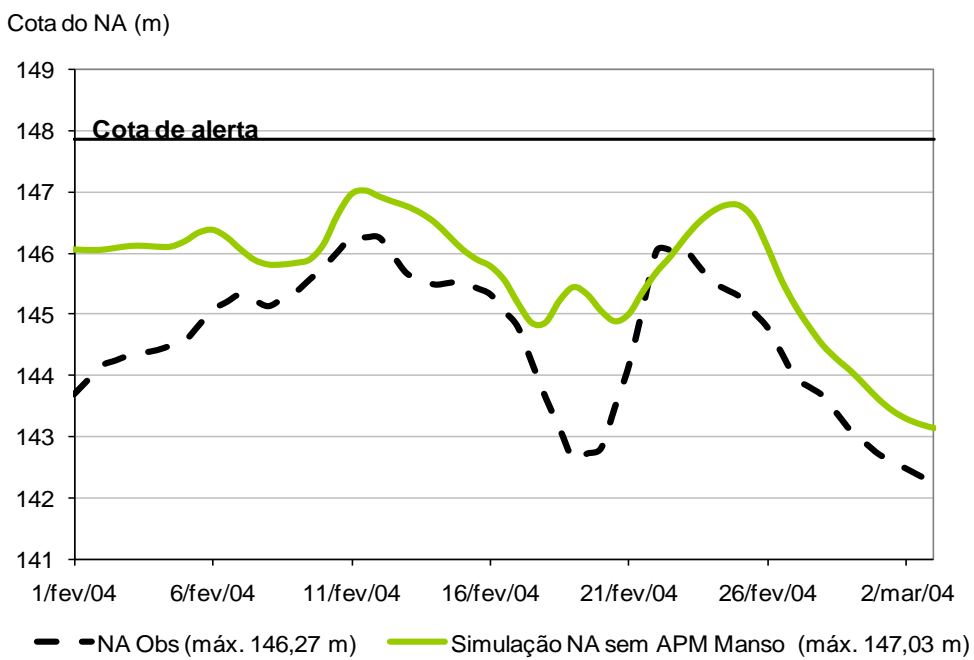

Figura 35 - Cotas de Cuiabá (2004)

A afluência do reservatório consistiu em três picos de proporções semelhantes, e o seu valor máximo foi de $1.143 \mathrm{~m} 3 / \mathrm{s}$; já a defluência máxima ao APM Manso foi de $468 \mathrm{~m}^{3} / \mathrm{s}$. De modo semelhante ao caso anterior, houve constância na descarga do reservatório, com ausência de um ponto máximo sobressalente.

Pelos gráficos da simulação hidrodinâmica é possível observar a existência de dois picos, isso sugere que o hidrograma do rio Cuiabá tenha adquirido características do rio Cuiabazinho. Os valores máximos observados permaneceram abaixo da cota de alerta, entre 0,63 m (em Rosário Oeste) e 1,59 m (em Cuiabá). Segundo os cálculos de níveis de água sem o amortecimento do reservatório, a cota de alerta não seria atingida durante todo o período, mesmo em Rosário Oeste, onde o nível não atingiria esse limite por diferença de 0,04 m. 


\subsubsection{Caso 2006}

A cheia de 2006 foi suficiente para alarmar boa parte das comunidades que habitam a bacia hidrográfica do rio Cuiabá. Essas circunstâncias se deram em razão do excesso de chuva em toda a BHC, em especial na sub-bacia de Manso. Houve o acúmulo excessivo de água no reservatório, que seguindo sua regra operacional, considerada arriscada por alguns especialistas, precisou verter grande quantidade de água, com perspectivas de aumento da vazão vertida nos dias posteriores. Com o potencial de amortecimento reduzido, a ocorrência de cheia passou a ser condicionada pela pluviosidade na bacia, que já estava elevada. Felizmente, devido à diminuição das chuvas nos dias seguintes, os níveis de água do rio baixaram sem maiores prejuízos. Os hidrogramas relativos ao amortecimento da onda de cheia proporcionado pelo reservatório de Manso são apresentados na Figura 36, e os resultados associados à cheia do referido ano nas Figuras 37 a 39.

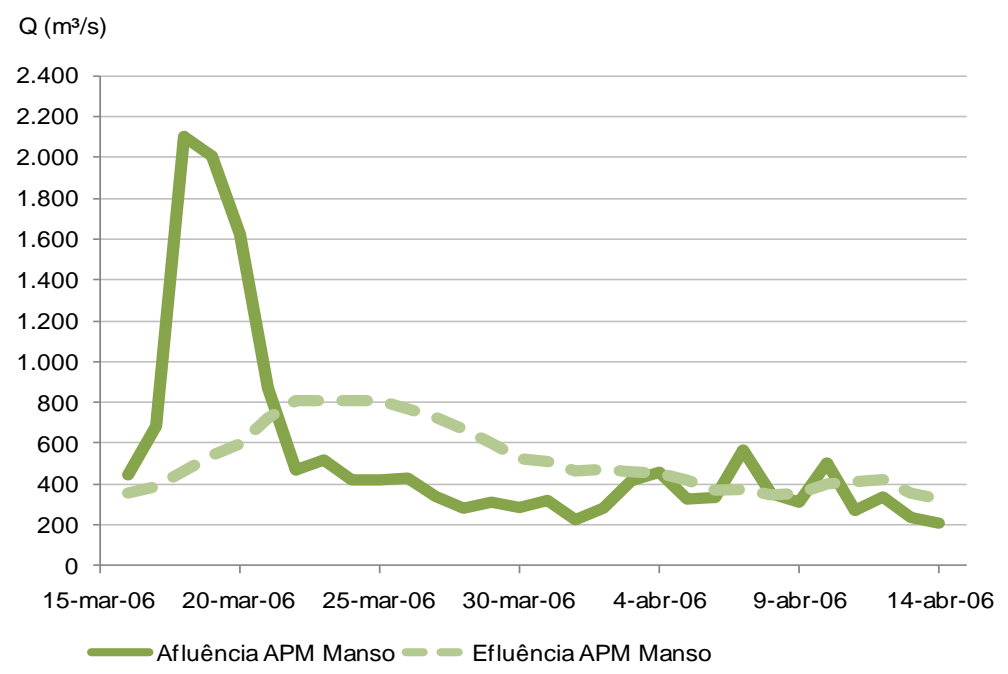

Figura 36 - Afluência e efluência no reservatório de Manso (2006) 


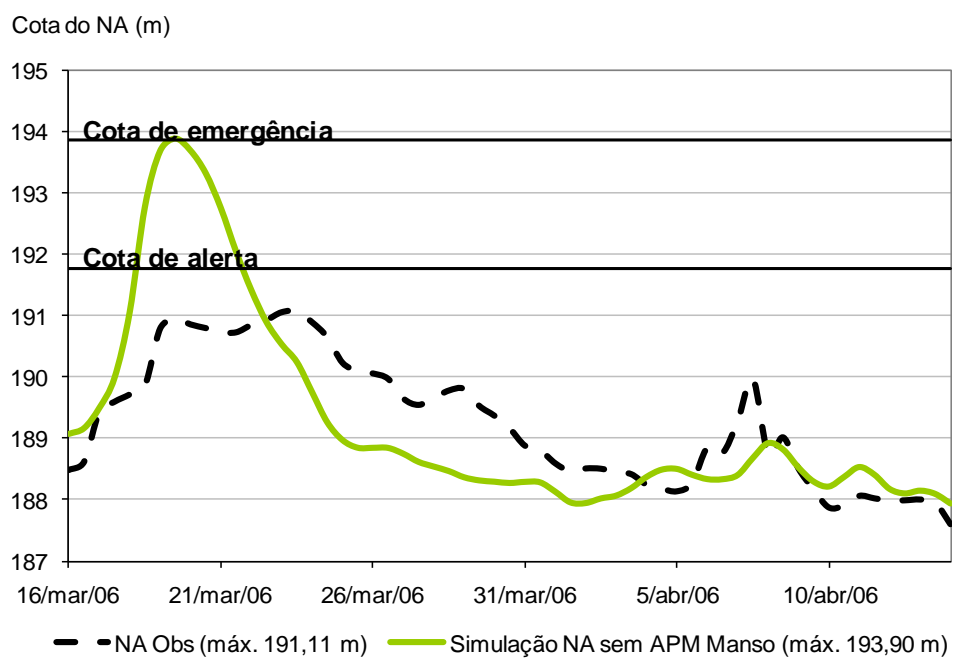

Figura 37 - Cotas de Rosário Oeste (2006)

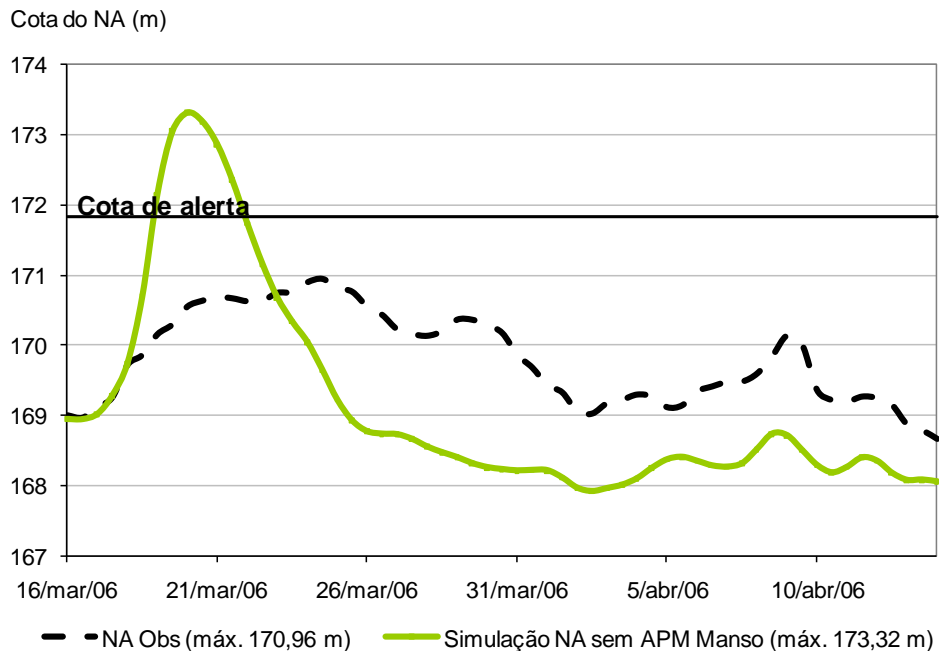

Figura 38 - Cotas de Acorizal (2006)

Cota do NA (m)

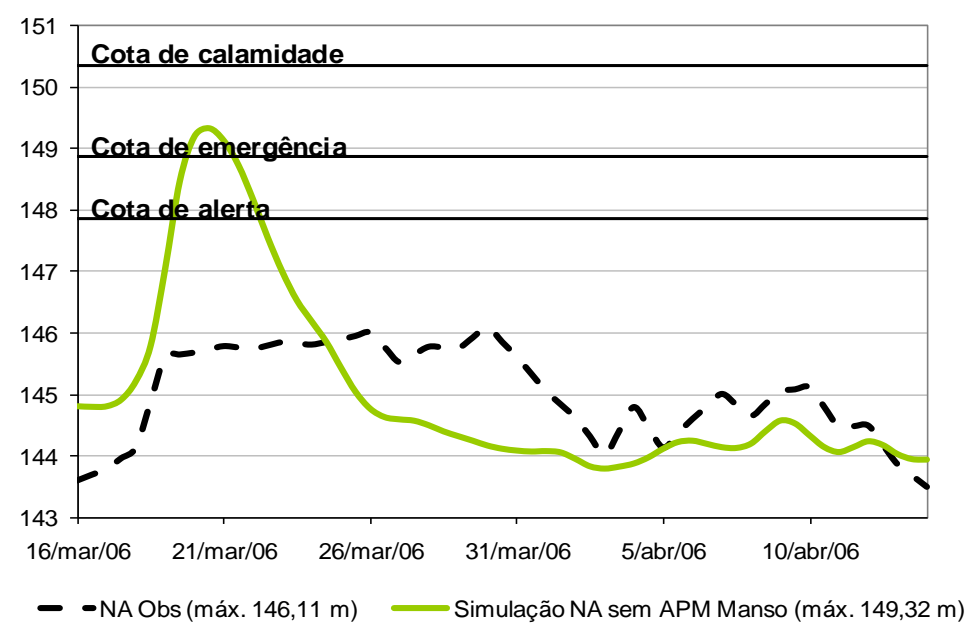

Figura 39 - Cotas de Cuiabá (2006) 
Os níveis de água observados nas seções a jusante não foram muito superiores aos dos anos 2002 e 2004. A comparação do pico afluente ao reservatório, $2.102 \mathrm{~m} / \mathrm{s}$, com a defluência máxima, $808 \mathrm{~m} 3 / \mathrm{s}$, equivalente a $62 \%$ daquele valor, permite afirmar que houve substancial amortecimento de vazões propiciado pelo reservatório.

Quanto à simulação hidrodinâmica, os níveis máximos estiveram entre 0,66 m para atingir a cota de alerta em Rosário Oeste e 1,75 m em Cuiabá. Entretanto, os cálculos apontaram que caso o APM Manso não existisse, a BHC seria testemunha de uma cheia de grandes proporções. O nível de água máximo do rio alcançaria a cota ortométrica 193,90 m em Rosário Oeste, 173,32 m em Acorizal e 149,32 m em Cuiabá. Isso significa que nas três cidades o nível de água ultrapassaria a cota de alerta, e excederia, ainda, em 0,46 m a cota de emergência em Cuiabá, suficiente para inundar considerável área na zona urbana. Pelos cálculos, caso o APM Manso não existisse, esta seria a sexta maior enchente na capital do estado desde o início das medições fluviométricas, em 1933.

$\mathrm{Na}$ época, representantes públicos foram à imprensa dar instruções sobre como proceder em caso de inundação. O sobreaviso gerado não pode ser considerado de todo inútil. Ele advém especialmente do fato de que pela primeira vez o reservatório exerceu o seu papel de amortecer as cheias na bacia do rio Cuiabá com forte influência, e, por isso, o seu desempenho foi questionado pela população.

As simulações de 2002, 2004 e 2006 apontam significativa redução dos níveis de água do rio Cuiabá nas três seções analisadas. Nos anos de 2002 e 2004 provavelmente não haveria inundações capazes de provocar grandes prejuízos aos munícipes, ainda assim, o amortecimento proporcionado pelo reservatório foi suficiente para eliminar eventuais ocorrências. A cheia de 2006 configurou verdadeiro teste aos responsáveis pela segurança dos habitantes da bacia, tanto no quesito de mobilização dos entes públicos, que envolveu as três esferas governamentais, quanto da operação do APM Manso.

É válido destacar a possibilidade de a cheia calculada pelo modelo hidrodinâmico não atingir as proporções calculadas para 2006, já que a calibração dessa ocorrência indicou alguma imprecisão no pico, com tendência a aumentar seu valor. Essa informação não elimina a assertiva de que a cheia do ano em questão seria alta, tendo em vista a vazão específica das sub-bacias a jusante (a terceira maior entre as 13) e os elevados valores que afluíram ao reservatório. 


\subsection{Cenário (ii)}

Neste cenário, é simulada a existência do APM Manso nas cheias de número 1, 7 e 8, atinentes a março de 1974, janeiro e fevereiro de 1995, consideradas as de maior prejuízo para os municípios da bacia do rio Cuiabá dentro do período de registros hidrológicos. A ideia é averiguar se a existência do reservatório de Manso nesses anos seria suficiente para evitar inundações em proporções tais como verificado, e em quanto o reservatório contribuiria para o amortecimento de cheias.

Para simular a situação, foi utilizado o método de Puls sobre as vazões observadas na estação fluviométrica do rio Manso durante os períodos de interesse. Para tanto, a regra de operação das comportas da usina foi levada em consideração. A condição de contorno de montante do sistema a ser aplicado no CLiv são os hidrogramas obtidos com esse método, que representam a defluência do suposto reservatório após o amortecimento. As vazões específicas adotadas foram 1.770,7 L.s ${ }^{-1} \cdot \mathrm{km}^{-1}$ (para 1974), 2.367,8 L.s ${ }^{-1} \cdot \mathrm{km}^{-1}$ (para janeiro de 1995) e $3.797,6 \mathrm{~L} . \mathrm{s}^{-1} \cdot \mathrm{km}^{-1}$ (para fevereiro de 1995), que correspondem aos períodos das respectivas cheias (de acordo com a Tabela 11).

\subsubsection{Caso 1974}

Conforme relatado no presente trabalho, a cheia de março de 1974 atingiu o maior nível de água já registrado no rio Cuiabá, e foi de tal proporção que gerou transformações importantes no conceito de enchentes na BHC. Ela desencadeou, por exemplo, estudos para a construção de usinas hidrelétricas na bacia, entre elas a UHE Manso. Além disso, os levantamentos das áreas de inundação na BHC tiveram início a partir deste ano; assim como o estabelecimento dos limites de segurança determinados pela Defesa Civil estadual, utilizados como referência de dimensão das cheias. Estimou-se que o período de retorno da cheia de 1974 foi equivalente a 50 anos (CARTA GEOTÉCNICA DE CUIABÁ,1990). O gráfico sobre o amortecimento teórico proporcionado pelo APM Manso é apresentado na Figura 40, e os níveis de água simulados hidraulicamente nos três municípios são apresentados nas Figuras 41 a 43. 


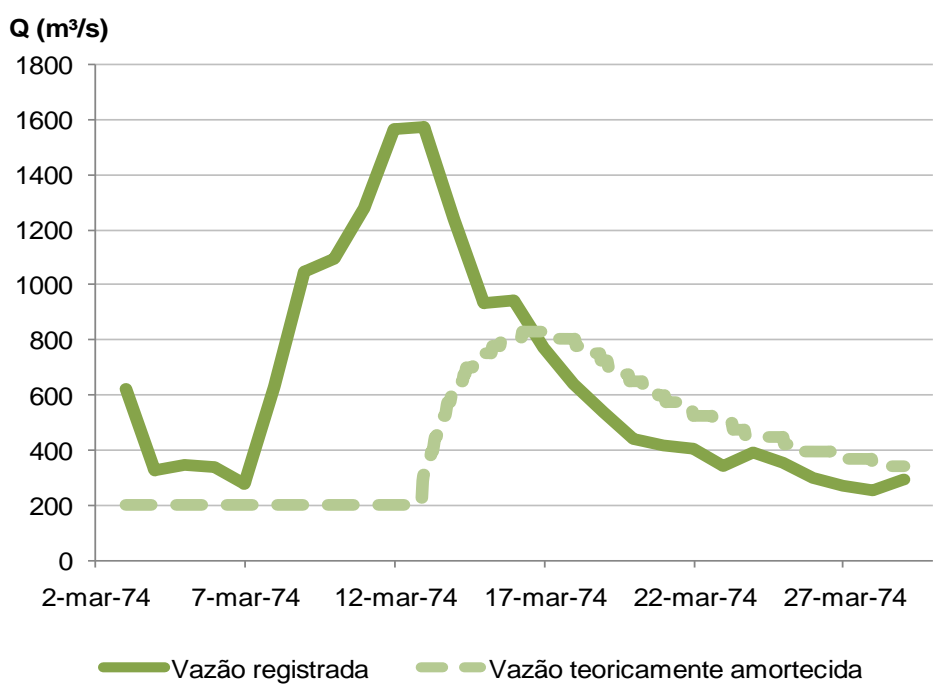

Figura 40 - Vazões registradas e teoricamente amortecidas (1974)

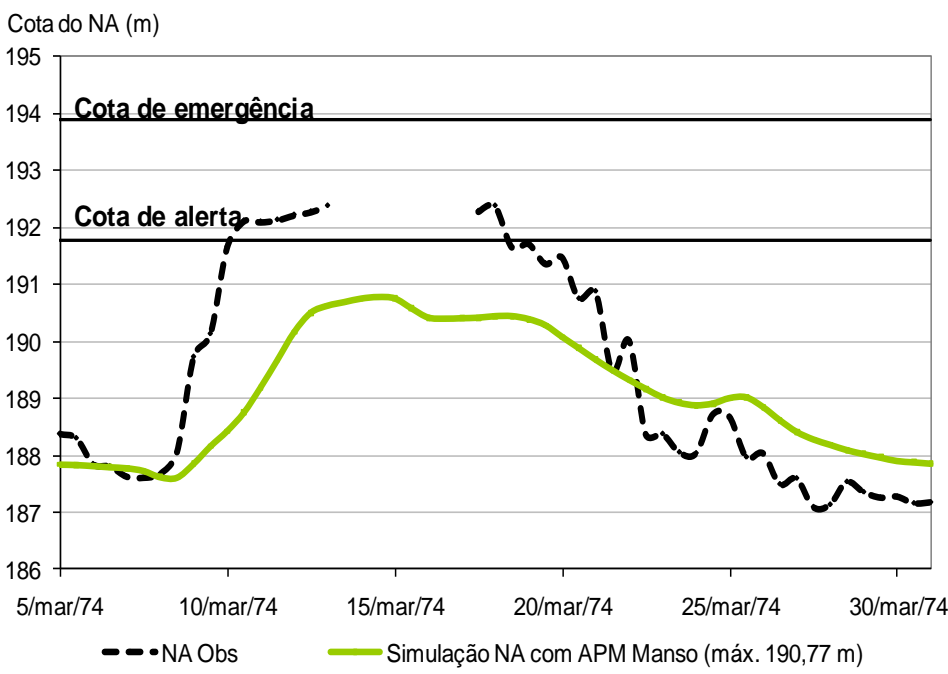

Figura 41 - Cotas de Rosário Oeste (1974)

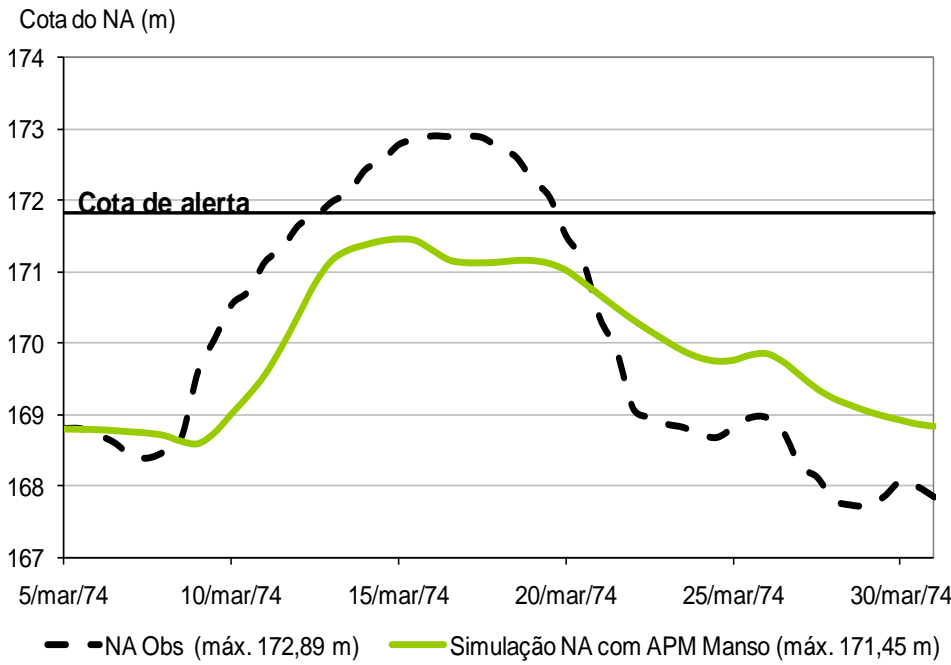

Figura 42 - Cotas de Acorizal (1974) 


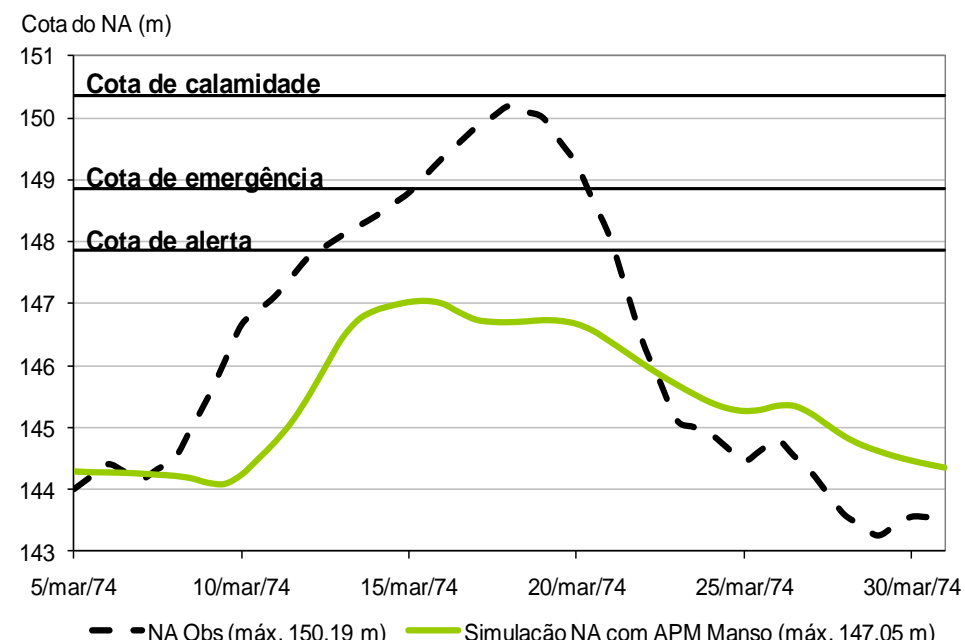

Figura 43 - Cotas de Cuiabá (1974)

A vazão máxima observada na estação UHE Manso foi $1.573 \mathrm{~m}^{3} / \mathrm{s}$. Segundo os cálculos, o amortecimento do reservatório seria tal que a vazão máxima defluente a ele não superaria 830 m³/s; o que representa redução do pico em $47 \%$.

A lacuna de quatro dias nos níveis de água observados em Rosário Oeste é explicada pela possível danificação da régua linimétrica ou pela impossibilidade de leitura devido ao nível máximo da régua ter sido excedido. Os valores observados em 1974 foram superiores às cotas de alerta nos três municípios, com destaque para Cuiabá, onde o nível de água atingiu altitude ortométrica de $150,19 \mathrm{~m}$, restando $0,17 \mathrm{~m}$ para a cota de calamidade.

O apreciável amortecimento proporcionado pelo reservatório poderia ter reduzido os níveis de água a ponto de sequer alcançar as cotas de alerta em quaisquer dos três municípios, assim, essa cheia poderia ter sido em escala tal que provavelmente não seriam contabilizados grandes prejuízos.

\subsubsection{Caso janeiro 1995}

No início de 1995, duas cheias de grandes dimensões aconteceram na BHC em meses subsequentes, não completamente independentes entre si. A primeira e menor delas, em janeiro, foi suficiente para causar algum transtorno à população da bacia. Avarias essas que só não foram maiores pois determinadas localidades inundadas pela cheia de 1974 foram legalmente proibidas (Lei Federal n. ${ }^{\circ}$ 6.766/1979) de serem ocupadas ainda naquela década. Apesar disso, a densidade populacional aumentou consideravelmente no intervalo de uma 
ocorrência para outra. Algumas regiões que haviam sido pouco atingidas em termos sociais na enchente mais antiga tiveram que ser desocupadas por grande número de moradores durante a cheia de 1995. Os resultados de amortecimento do reservatório de Manso em relação à referida cheia estão expostos na Figura 44; ao passo que os relativos à modelagem hidrodinâmica são apresentados nas Figuras 45 a 47.

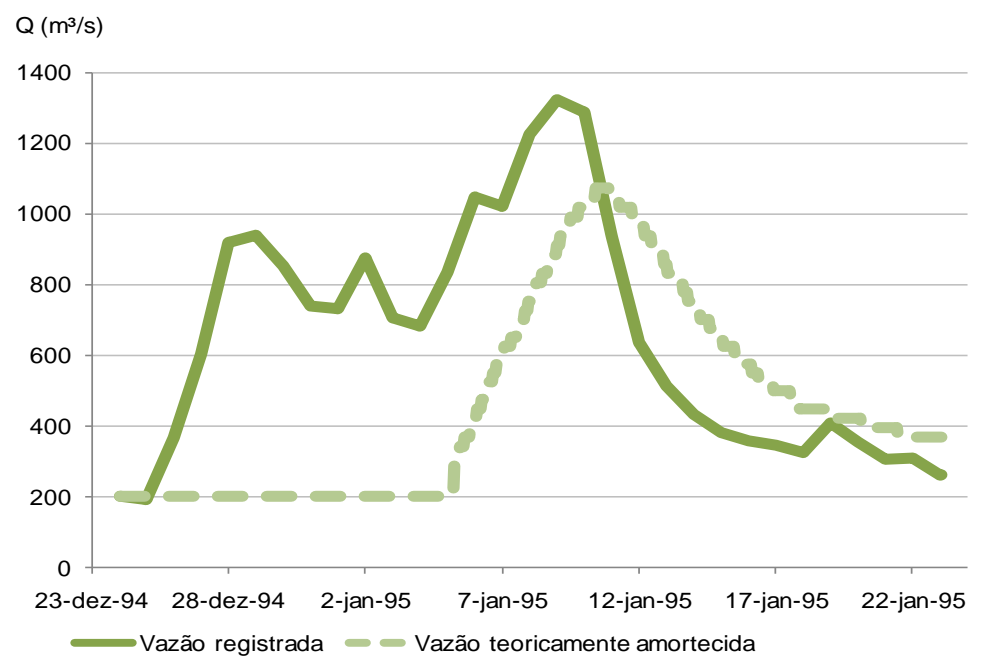

Figura 44 - Vazões registradas e teoricamente amortecidas (Jan/1995)

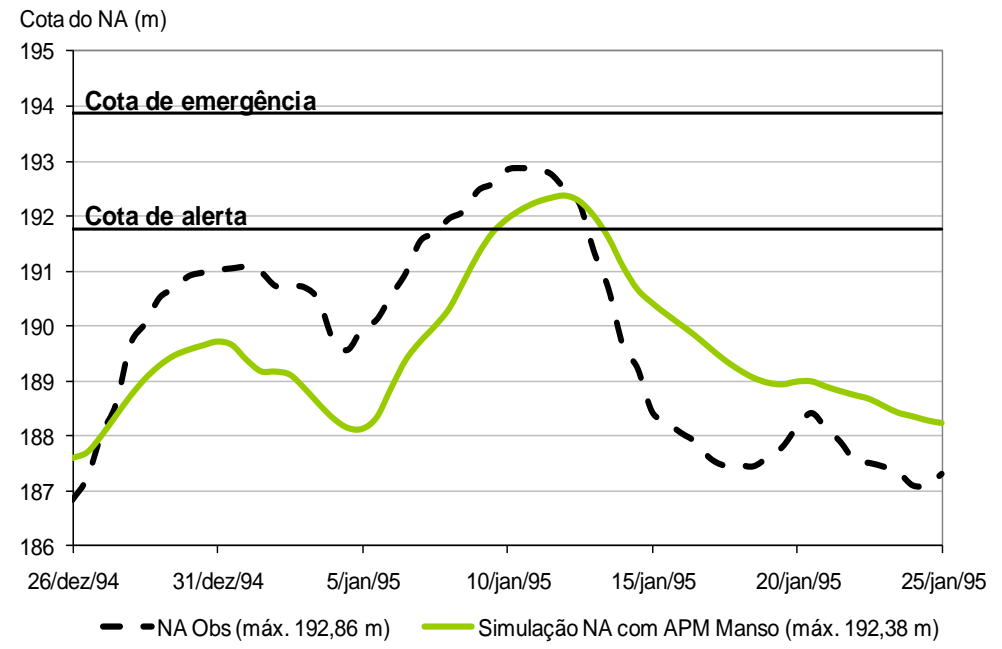

Figura 45 - Cotas de Rosário Oeste (Jan/1995) 


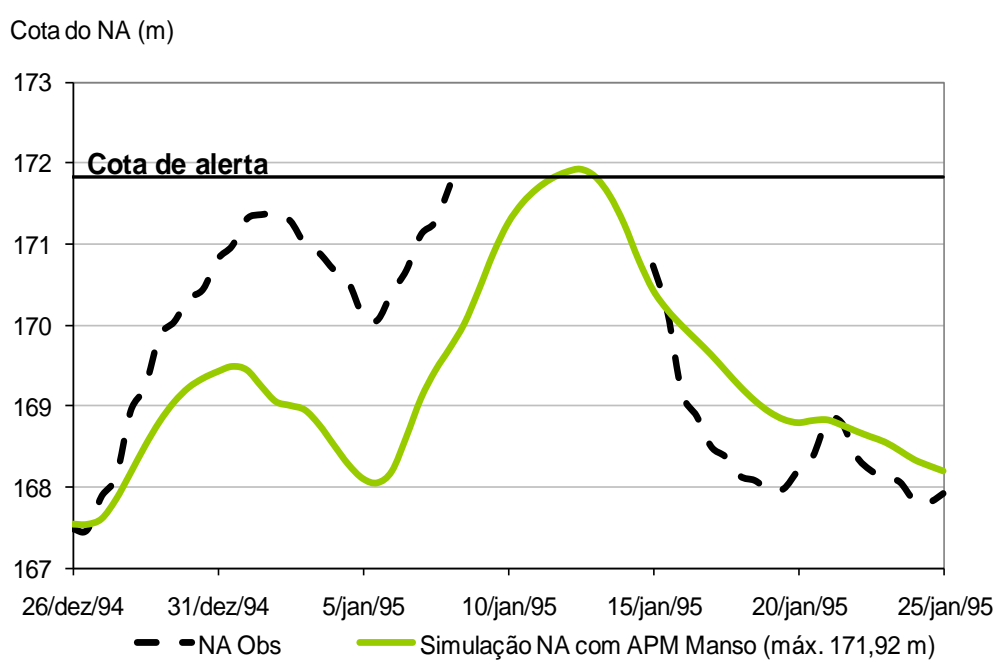

Figura 46 - Cotas de Acorizal (Jan/1995)

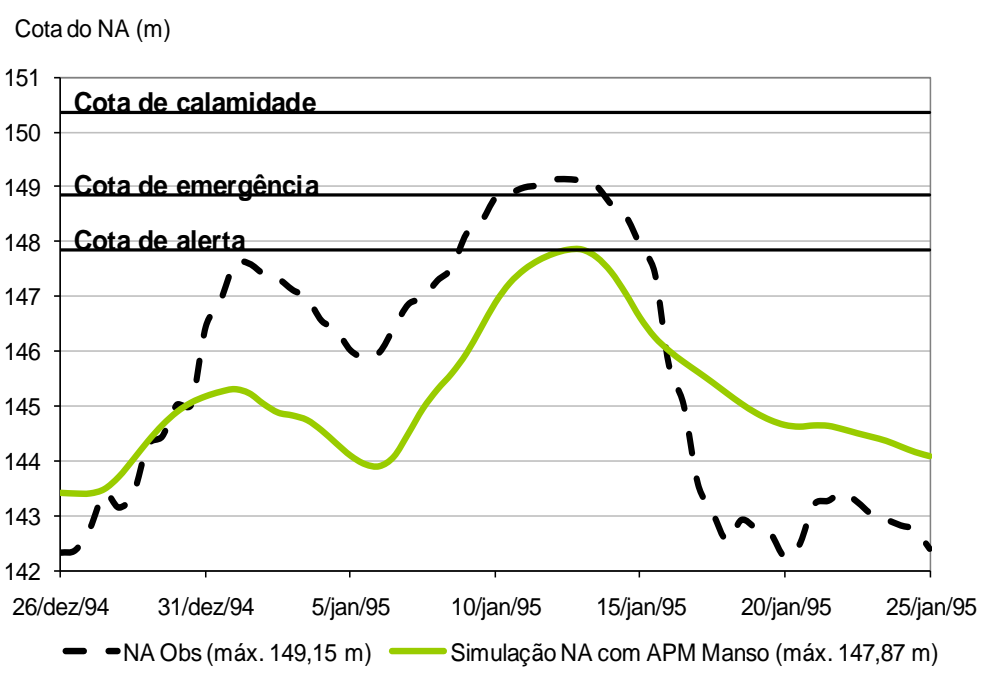

Figura 47 - Cotas de Cuiabá (Jan/1995)

A vazão máxima registrada na estação fluviométrica da UHE Manso foi de $1.321 \mathrm{~m}^{3} / \mathrm{s}$. O cálculo do amortecimento de cheias indicou que essa vazão poderia ser reduzida em 19\%, com valor máximo de $1.071 \mathrm{~m} / \mathrm{s}$.

Os níveis de água observados em janeiro de 1995 ultrapassaram as cotas de alerta nas três cidades. Em Rosário Oeste, o nível de água foi maior que a cota de alerta em 1,09 m, enquanto em Cuiabá mesmo a cota de emergência foi superada, em 0,29 m. Há ausência de dados observados na estação fluviométrica de Acorizal durante o período crítico da cheia tanto em janeiro quanto em fevereiro, mas isso não impede a observação da dimensão que os níveis de água atingiram em ambas as situações. 
A existência do reservatório de Manso teria amenizado em parte a intensidade da cheia, em especial na capital mato-grossense, onde o pico teria recuado 1,29 m e permanecido na cota de alerta. Em Rosário Oeste o nível de água seria 0,48 m menor, porém ainda acima da cota de alerta em 0,61 m. A falta de dados impossibilita a informação precisa a respeito do nível de água em Acorizal, que aparentemente seria elevado. De todo modo, a existência do reservatório limitaria o nível de água em 0,09 m acima da cota de alerta desta cidade.

\subsubsection{Caso fevereiro 1995}

O primeiro trimestre de 1995 foi o de maior altura precipitada na região da bacia do Cuiabá em 38 anos de registros pluviométricos. A cheia de fevereiro de 1995 foi causada essencialmente pela elevada quantidade de chuva, e estimulada pelo fato de o solo estar saturado com a enchente no mês anterior. Nas Figuras 48 a 51 estão os resultados do amortecimento do reservatório de Manso e da simulação hidrodinâmica nas três seções consideradas.

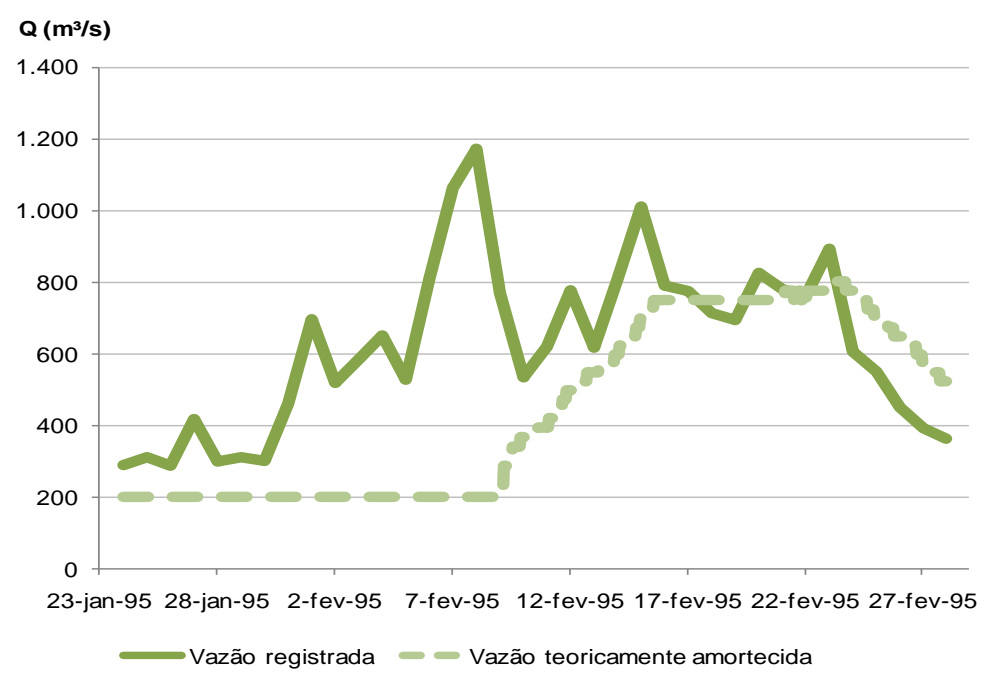

Figura 48 - Vazões registradas e teoricamente amortecidas (Fev/1995) 


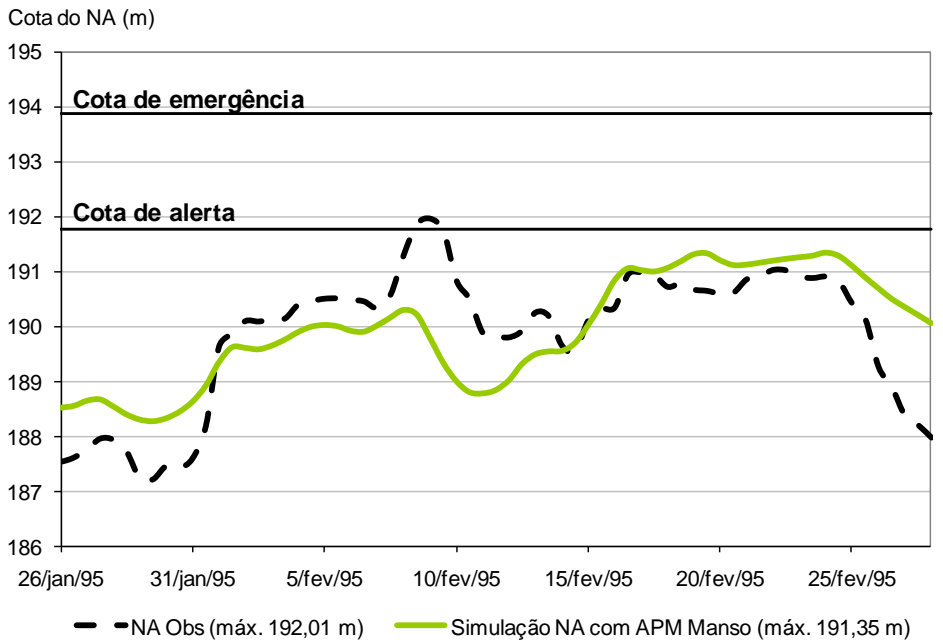

Figura 49 - Cotas de Rosário Oeste (Fev/1995)

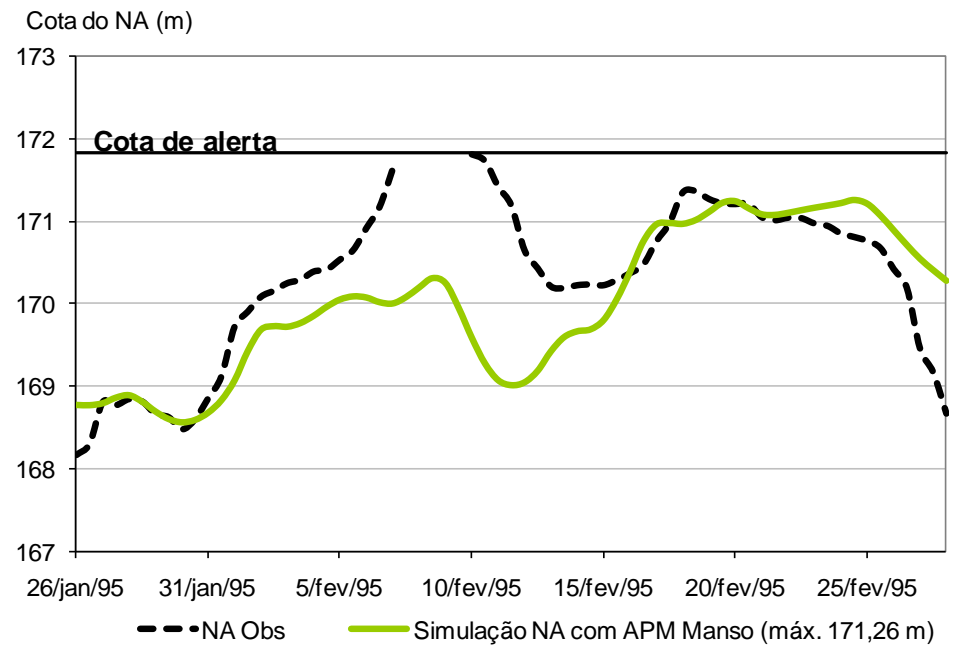

Figura 50 - Cotas de Acorizal (Fev/1995)

Cota do NA (m)

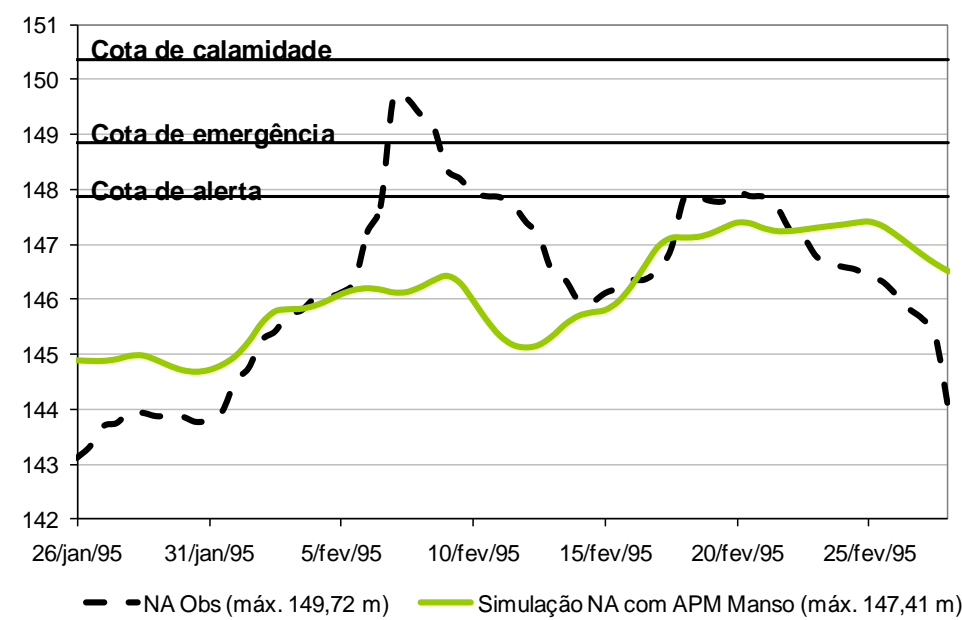

Figura 51 - Cotas de Cuiabá (Fev/1995) 
A vazão observada na estação fluviométrica da estação UHE Manso foi equivalente a $1.173 \mathrm{~m}$ 3/s. O amortecimento do reservatório reduziria esse valor em $31 \%$, e a defluência máxima do APM Manso seria 803 m³/s.

O nível de água observado atingiu o limite da cota de alerta nas três seções estudadas. Em Cuiabá, mesmo a de emergência foi superada, em 0,86 m. O modelo hidrodinâmico apontou que o amortecimento da onda de cheia pelo reservatório reduziria os níveis de água máximos para cotas inferiores às de alerta nas três seções avaliadas. Em Rosário Oeste, a diminuição do pico seria de 0,66 m e em Cuiabá de 2,31 m. Além da redução do nível de água, pode ser observado que o amortecimento atrasaria o pico de cheia em pouco mais de uma semana.

Segundo as simulações, as vantagens proporcionadas pelo reservatório de Manso em termos de atenuação de vazões seriam grandes. Em dois dos casos testados as cheias não teriam alcançado sequer as cotas de segurança estipuladas pela SUDEC/MT, e em um deles o nível de água máximo atingiria a cota de alerta, o mais baixo entre os limites de segurança. Deve ser respeitado o fato de que a obediência às regras operacionais das comportas do reservatório, da forma como realizado neste trabalho, consistiu em bases totalmente teóricas, que nem sempre podem ser minuciosamente seguidas em função dos diversos fatores envolvidos. Entre eles são citados a possibilidade de manutenção de certas unidades da usina, que resultaria em modificação da efluência; ou a necessidade de redução do vertimento devido às altas vazões da bacia incremental, advindas dos tributários. A admissão dessas condições ótimas pode influenciar, ainda, a capacidade de amortecimento ao ignorar possíveis cheias de dias anteriores que não permitissem que o ponto inicial do cálculo fosse o nível máximo normal de operação do reservatório, conforme estabelecido na regra operacional.

\subsection{Cenário (iii)}

No presente cenário, é estudada a suposição de cheias de projeto afluentes ao reservatório de Manso com períodos de retorno críticos. São cinco casos específicos: TR 50 anos, TR 100 anos, TR 1.000 anos, TR 10.000 anos e a vazão máxima provável (QMP). A ideia principal deste estudo é avaliar qual o comportamento do rio Cuiabá nas ocasiões dos períodos de retorno testados tendo em conta a capacidade do amortecimento do APM Manso.

Para tanto, as cheias de projeto críticas da sub-bacia de Manso foram teoricamente amortecidas de acordo com o método de Puls. Os resultados deste cálculo, que representam a 
efluência do reservatório após o amortecimento, foram utilizados como condição de contorno de montante do sistema na aplicação do CLiv. Conforme mencionado, para considerar a variação hidrológica na bacia intermediária, foram simuladas três vazões específicas diferentes para cada tempo de recorrência (apresentados na Tabela 13, na página 87). São elas a média aritmética (Qinc), o dobro (2x Qinc) e a metade ( 0,5 x Qinc) das vazões específicas em que não é computada a sub-bacia do rio Manso (Tabela 12, na página 86).

\subsubsection{TR 50 anos}

O amortecimento do APM Manso é apresentado na Figura 52, já os resultados hidrodinâmicos referentes aos períodos de retorno de 50 anos na sub-bacia do rio Manso, nas três vazões específicas mencionadas, estão nas Figuras 53 a 55.

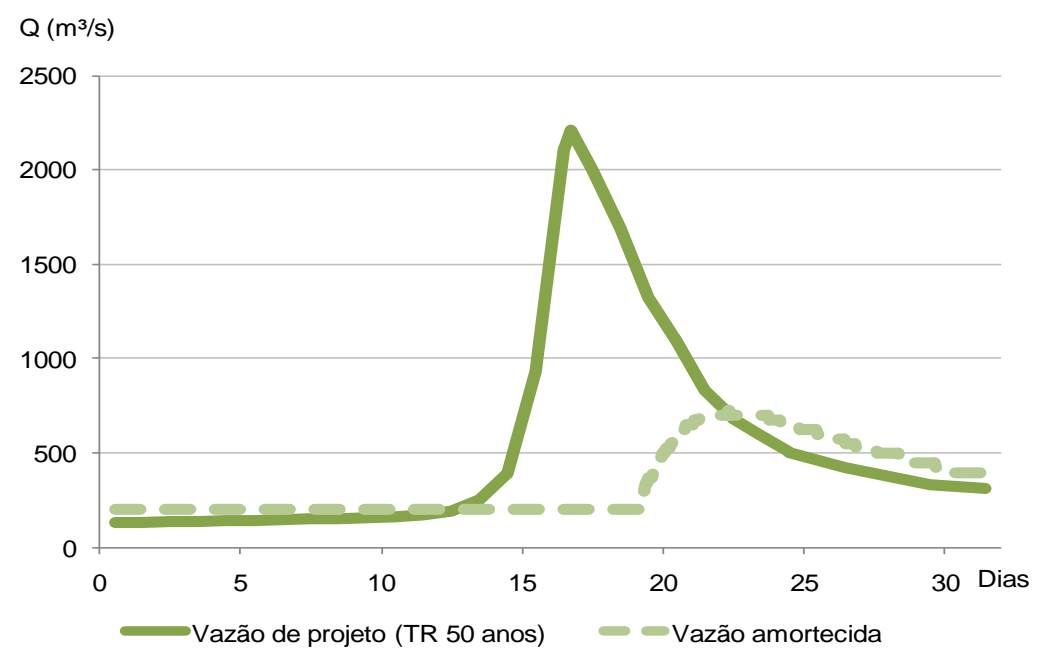

Figura 52 - Amortecimento da cheia de projeto TR 50 anos no rio Manso 


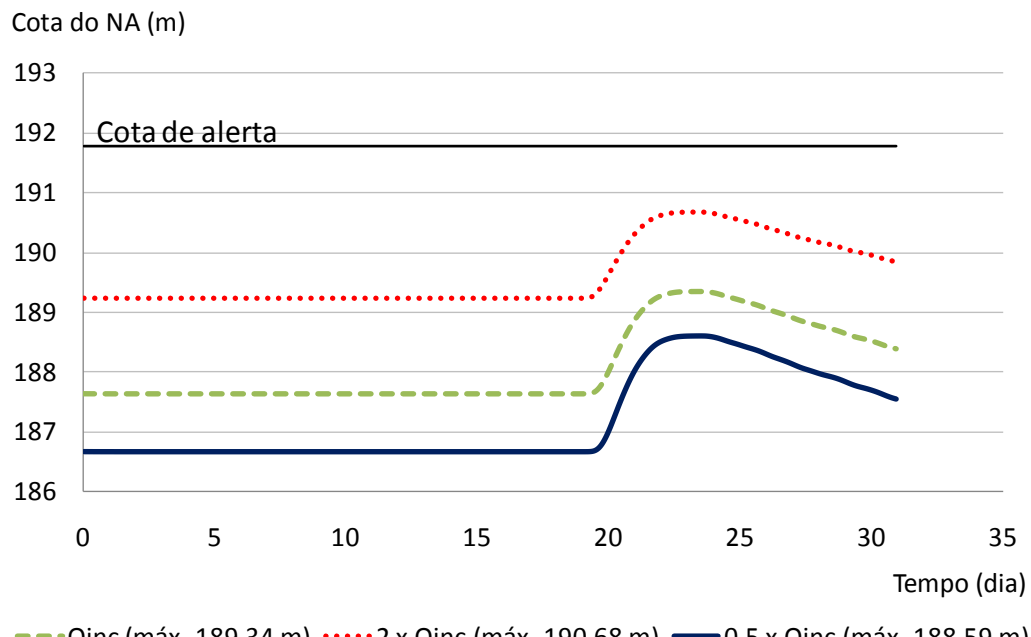

Figura 53 - Cotas Rosário Oeste (TR 50 anos)

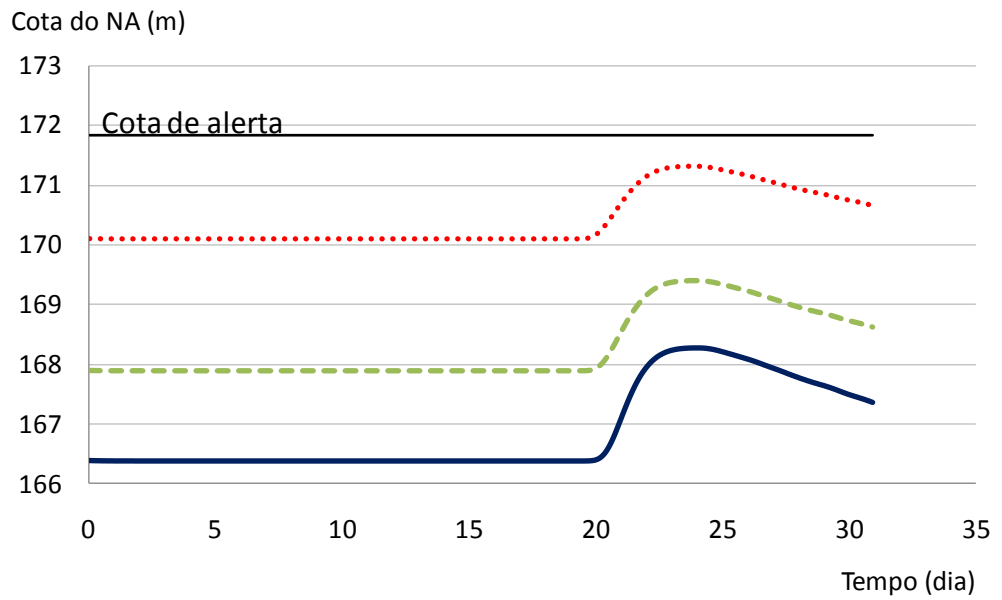

-- Qinc (máx. 169,41 m) …2 x Qinc (máx. 171,31 m) -0,5 x Qinc (máx. 168,28 m)

Figura 54 - Cotas Acorizal (TR 50 anos)

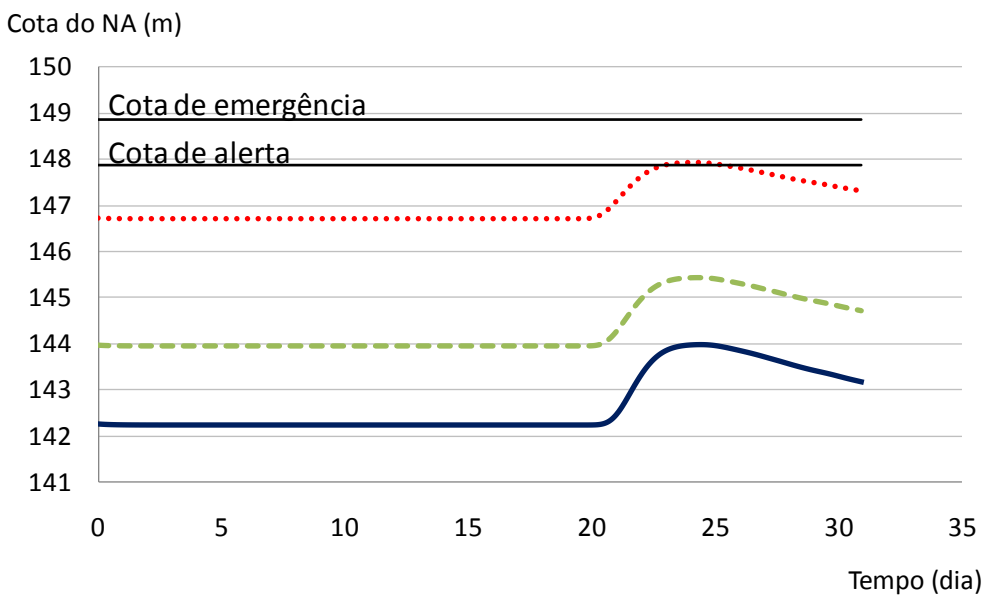

---Qinc (máx. 145,44 m) …22 x Qinc (máx. 147,92 m) -0,5xQinc (máx. 143,99 m)

Figura 55 - Cotas Cuiabá (TR 50 anos) 
A cheia com período de retorno de 50 anos na sub-bacia do Manso, a montante da usina hidrelétrica, tem máxima de $2.206 \mathrm{~m} / \mathrm{s}$. O amortecimento proporcionado pelo reservatório é capaz reduzir o pico em aproximadamente $67 \%$. Nessa condição, a vazão máxima defluente ao APM Manso é de 724 m³/s.

No que compete aos resultados da modelagem hidrodinâmica, somente com a situação da vazão específica máxima entre as três examinadas o nível de água atingiria a cota de alerta em Cuiabá, superando-a em 0,06 m. Nas demais seções estudadas, mesmo com as vazões incrementais mais altas, a cota mencionada não seria alcançada.

\subsubsection{TR 100 anos}

Nas Figuras 56 a 59 estão expostos os resultados do amortecimento do reservatório e das simulações da cheia de projeto com períodos de retorno equivalente a 100 anos na subbacia do rio Manso, ao levar em consideração as três vazões específicas adotadas.

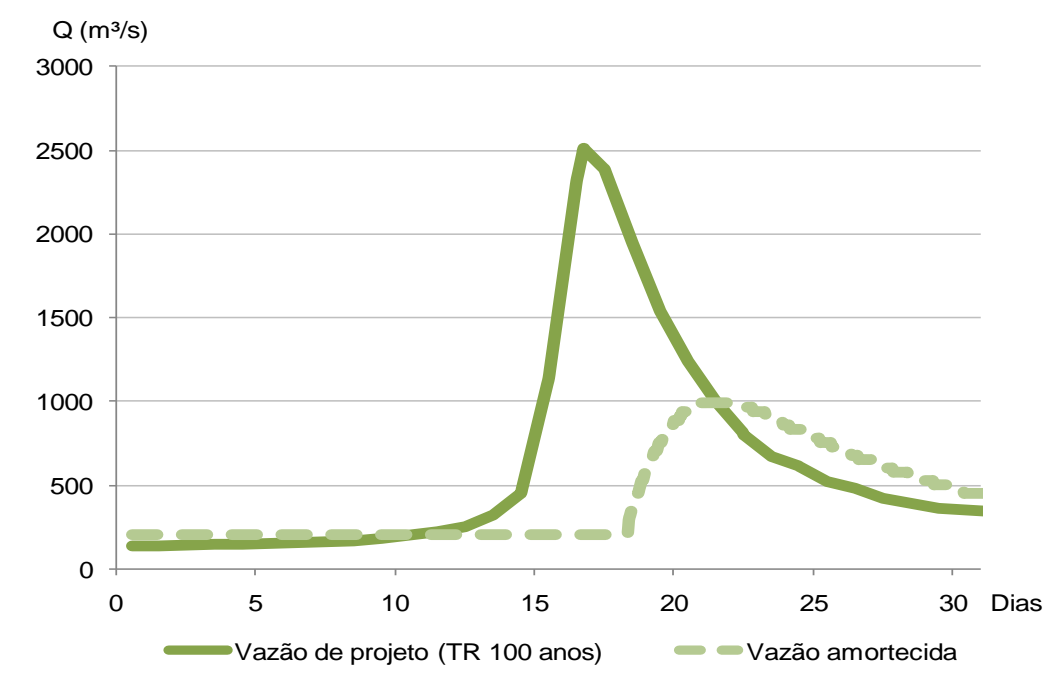

Figura 56 - Amortecimento da cheia de projeto TR 100 anos no rio Manso 


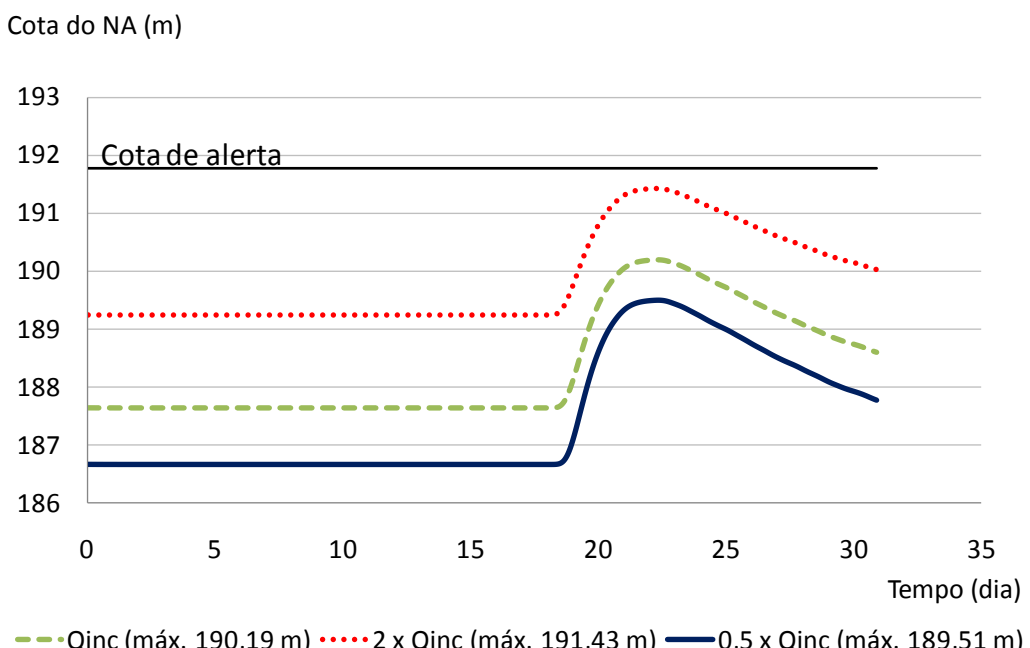

Figura 57 - Cotas Rosário Oeste (TR 100 anos)

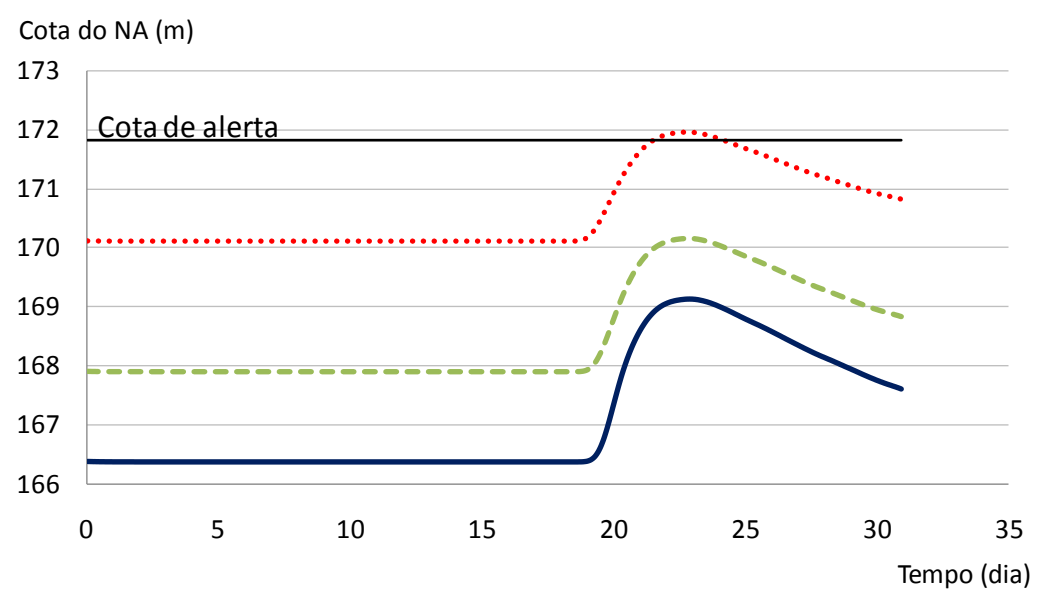

- - Qinc (máx. 170,15 m) …2 x Qinc (máx. 171,96 m) 0,5 x Qinc (máx. 169,14 m)

Figura 58 - Cotas Acorizal (TR 100 anos)

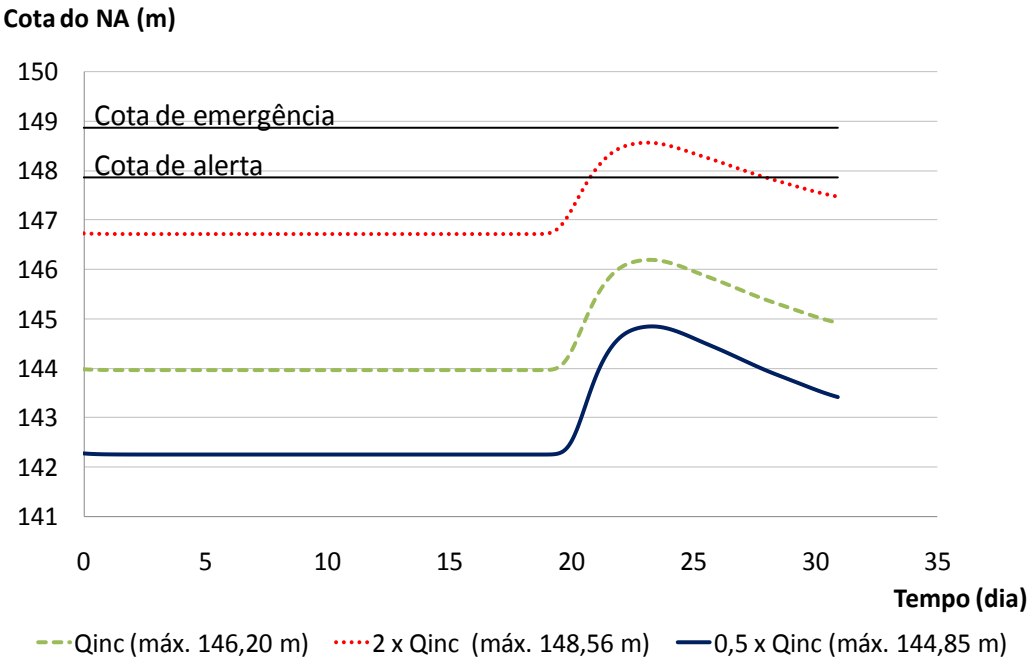

Figura 59 - Cotas Cuiabá (TR 100 anos) 
$\mathrm{Na}$ situação de tempo de recorrência secular, a vazão máxima é $2.514 \mathrm{~m} 3 / \mathrm{s}$. A atenuação da cheia pelo reservatório reduz este valor em $61 \%$, para $989 \mathrm{~m} 3 / \mathrm{s}$.

Quanto à simulação hidrodinâmica, para a maior vazão específica, os níveis de alerta seriam alcançados nos municípios de Acorizal e Cuiabá. Neste último, a cota atingida seria 0,70 m superior à de alerta, adquirindo escala pouco menor à ocorrência de janeiro de 1995 . $\mathrm{Na}$ opção pelas vazões específicas menores, correspondentes à média aritmética e à metade dessa média, as cotas de segurança não seriam alcançadas.

\subsubsection{TR 1.000 anos}

Os resultados dos testes com cheia de projeto afluente à UHE Manso com 1.000 anos de recorrência estão apresentados nas Figuras 60 a 63.

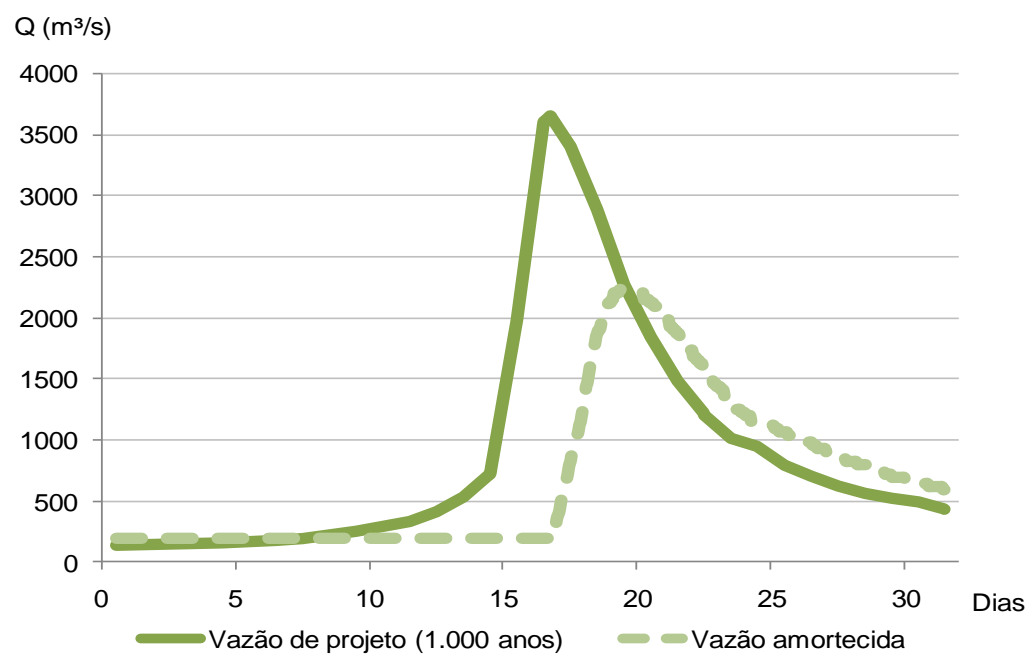

Figura 60 - Amortecimento da cheia de projeto TR 1.000 anos no rio Manso 


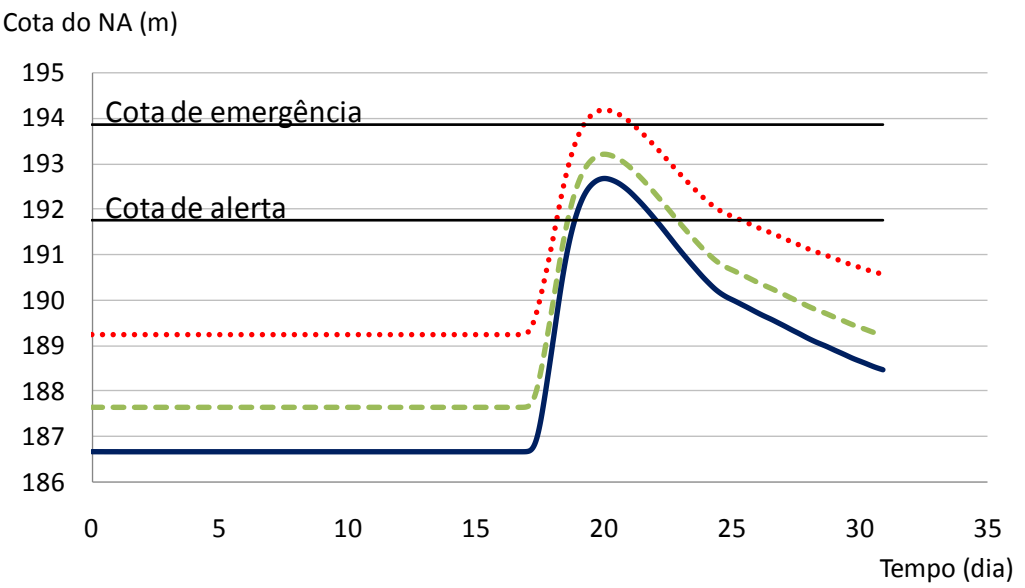

- - Qinc (máx. 193,20 m) ….2 x Qinc (máx. 194,20 m) —0,5 x Qinc (máx. 192,68 m)

Figura 61 - Cotas Rosário Oeste (TR 1.000 anos)

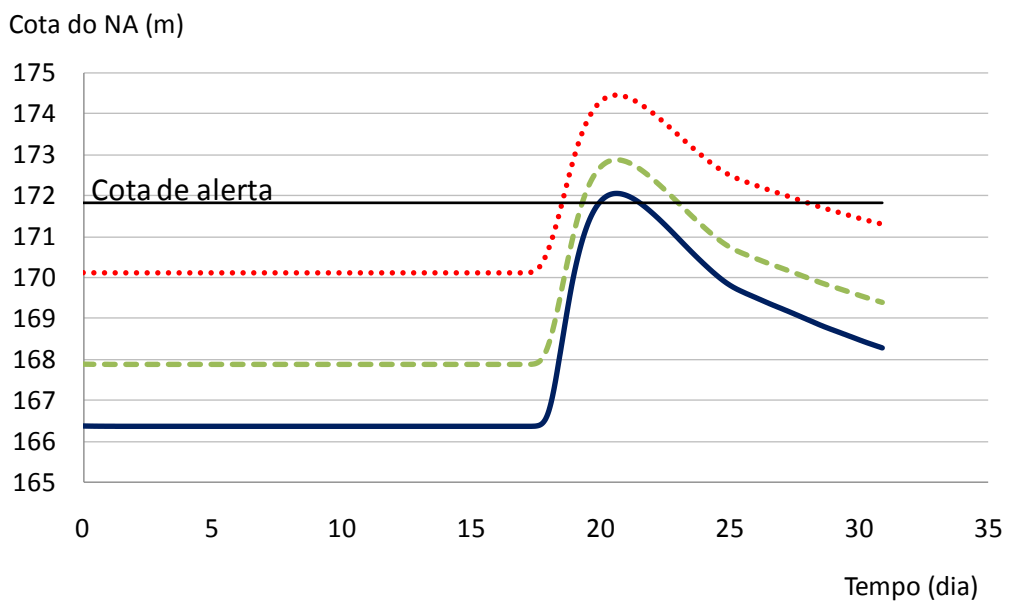

- - Qinc (máx. 172,87 m) …2 x Qinc (máx. 174,45 m) —0,5 x Qinc (máx. 172,05 m)

Figura 62 - Cotas Acorizal (TR 1.000 anos)

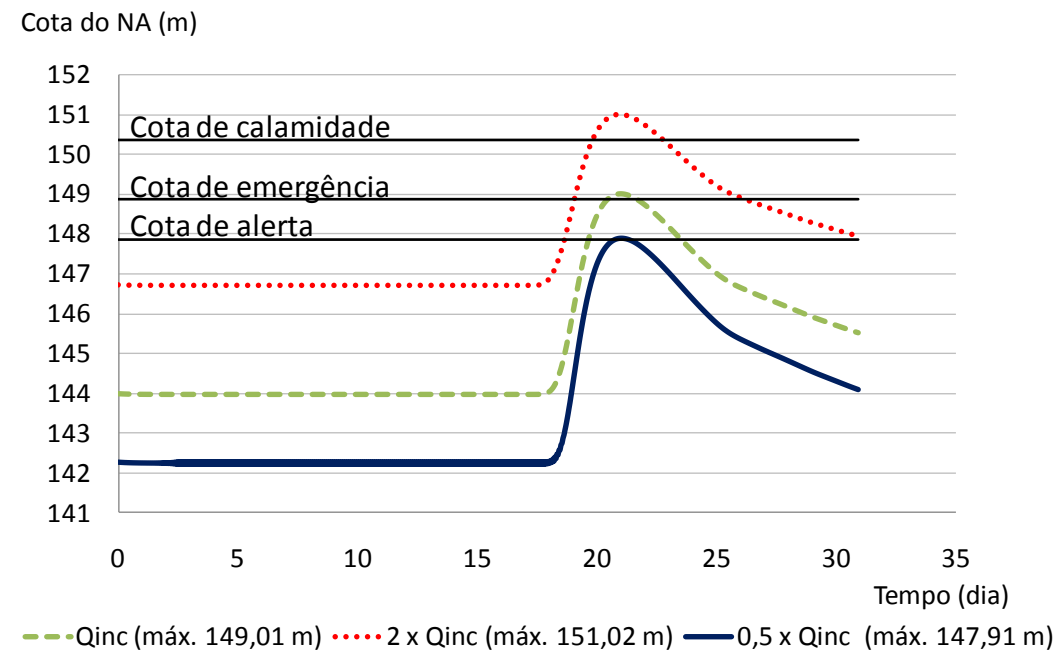

Figura 63 - Cotas Cuiabá (TR 1.000 anos) 
As cheias de projeto com período de retorno milenar afluente ao APM Manso possuem vazão máxima de $3.650 \mathrm{~m}^{3} / \mathrm{s}$. Com o amortecimento do reservatório a cheia tem pico de $2.237 \mathrm{~m}$ 3/s, representando redução de aproximadamente $39 \%$ da vazão máxima afluente.

Em cheias com essas proporções, os níveis de água seriam suficientes para ultrapassar todas as cotas de segurança nas três cidades ao ser considerada a maior vazão específica entre as adotadas. Seus valores superariam em 0,66 m a cota de calamidade em Cuiabá, em 2,58 m que a de alerta em Acorizal e em 0,33 m que a cota de emergência em Rosário Oeste.

Cabe observar que se forem atribuídas ao modelo as menores vazões específicas - o que consistiria em um fato curioso, visto constar de uma cheia extrema na sub-bacia do Manso enquanto não em suas vizinhas - mesmo os menores níveis de segurança seriam atingidos em todos os municípios analisados. Caso escolhida a média das vazões específicas, as cotas de alerta seriam ultrapassadas nos dois municípios de montante, enquanto em Cuiabá o nível de água seria superior em $0,15 \mathrm{~m}$ a cota de emergência.

\subsubsection{TR 10.000 anos}

As cheias decamilenares são ponto de referência no planejamento de qualquer usina hidrelétrica por servirem de base para o dimensionamento dos vertedores. As Figuras 64 a 67 ilustram o amortecimento do reservatório de Manso e os prováveis níveis do rio Cuiabá na ocorrência de uma cheia dessa escala na sub-bacia do Manso.

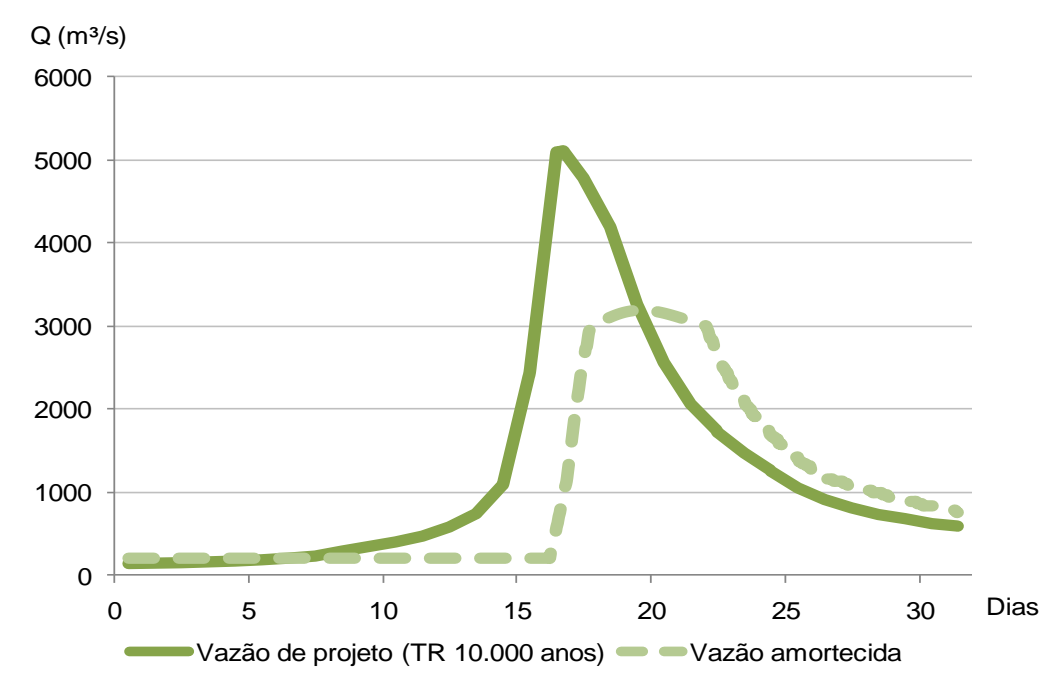

Figura 64 - Amortecimento da cheia de projeto TR 10.000 anos no rio Manso 


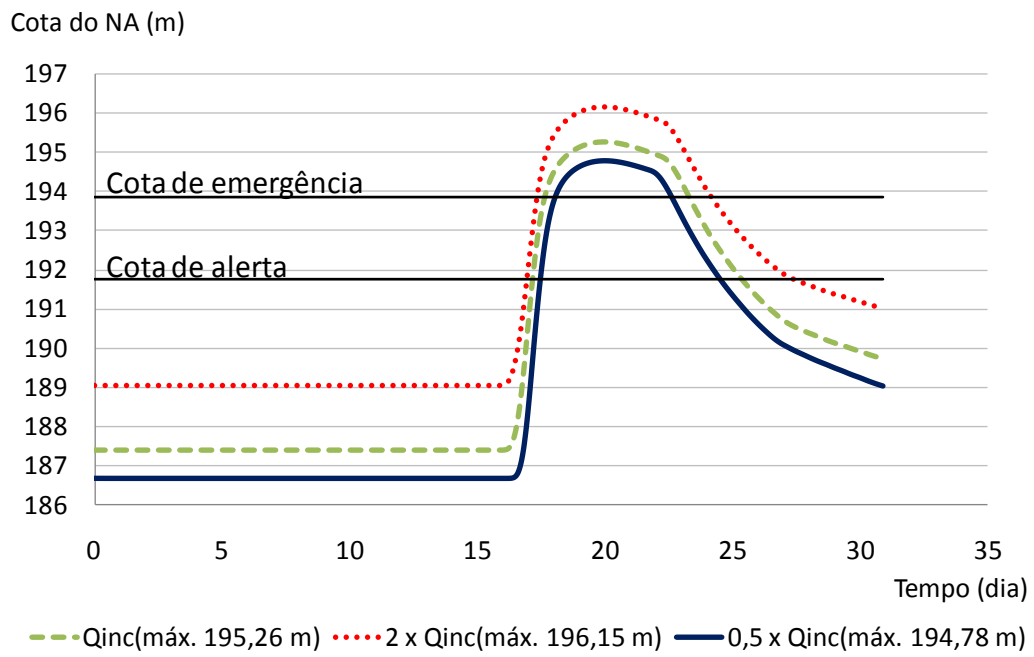

Figura 65 - Cotas Rosário Oeste (TR 10.000 anos)

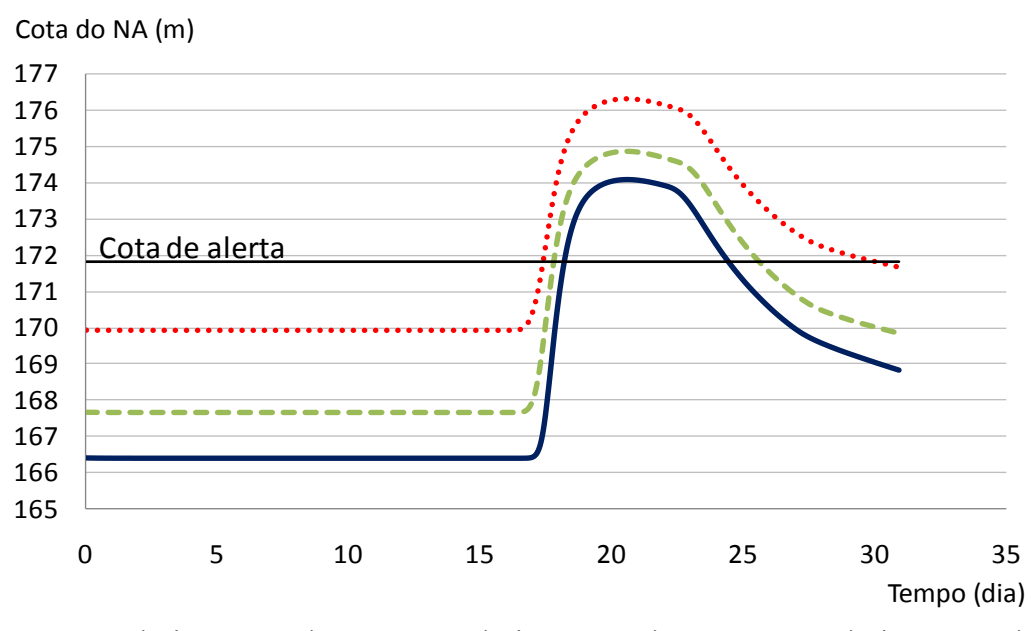

- - Qinc (máx. 174,87 m) …2 x Qinc (máx. 176,32 m) —0,5 x Qinc (máx. 174,10 m)

Figura 66 - Cotas Acorizal (TR 10.000 anos)

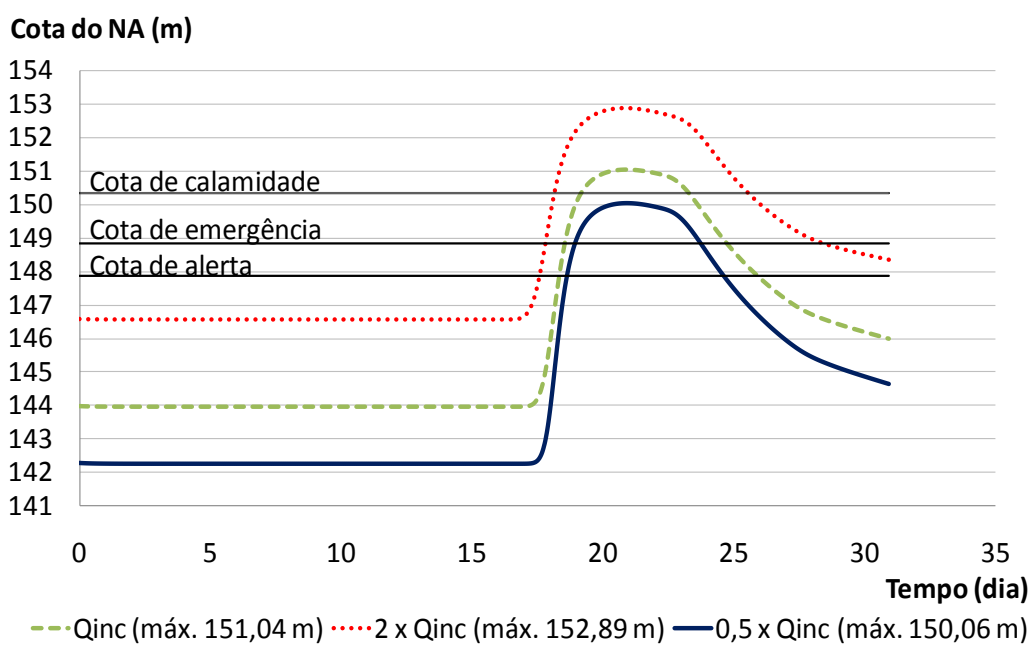

Figura 67 - Cotas Cuiabá (TR 10.000 anos) 
A cheia decamilenar a montante do reservatório de Manso resulta em vazão máxima de $5.106 \mathrm{~m}^{3} / \mathrm{s}$ na estação fluviométrica correspondente. O APM Manso é capaz de amortecer essa cheia o suficiente para que a vazão máxima defluente seja igual a $3.182 \mathrm{~m} 3 / \mathrm{s}$, ou seja, redução aproximada de $38 \%$.

Conforme pode ser visto, mesmo que a menor vazão específica entre as escolhidas seja carregada no modelo hidrodinâmico, os níveis de água máximos em Cuiabá se equiparariam ao da cota de calamidade estabelecida pela Defesa Civil estadual, e ultrapassariam as cotas de segurança mais elevadas nos outros municípios. Com a adoção da maior vazão específica, os níveis máximos superariam em 2,28 m a cota de emergência em Rosário Oeste, em 4,49 m a de alerta em Acorizal e em 2,53 m a de calamidade em Cuiabá.

\subsubsection{QMP - Vazão máxima provável}

Cheias superiores ao período de recorrência de 10.000 anos em bacias hidrográficas onde há operação de UHE's comumente exprimem situação crítica da estrutura hidráulica da usina, pois esta pode ser destruída, já que ela normalmente é projetada para suportar no máximo até tal risco. Na simulação de rompimento de barragem - o que é provável de acontecer na eminência de cheias dessa grandeza - devem ser admitidos fatores como a dimensão da brecha formada e informações atinentes à descarga sólida. Dessa forma, para efeitos de cálculo, o amortecimento do reservatório sobre a QMP na sub-bacia de Manso a montante da usina foi estimado sem que tenha havido quaisquer danos à construção. Os resultados do amortecimento da onda de cheia e da simulação da sua propagação estão expostos nas Figuras 68 a 71. 


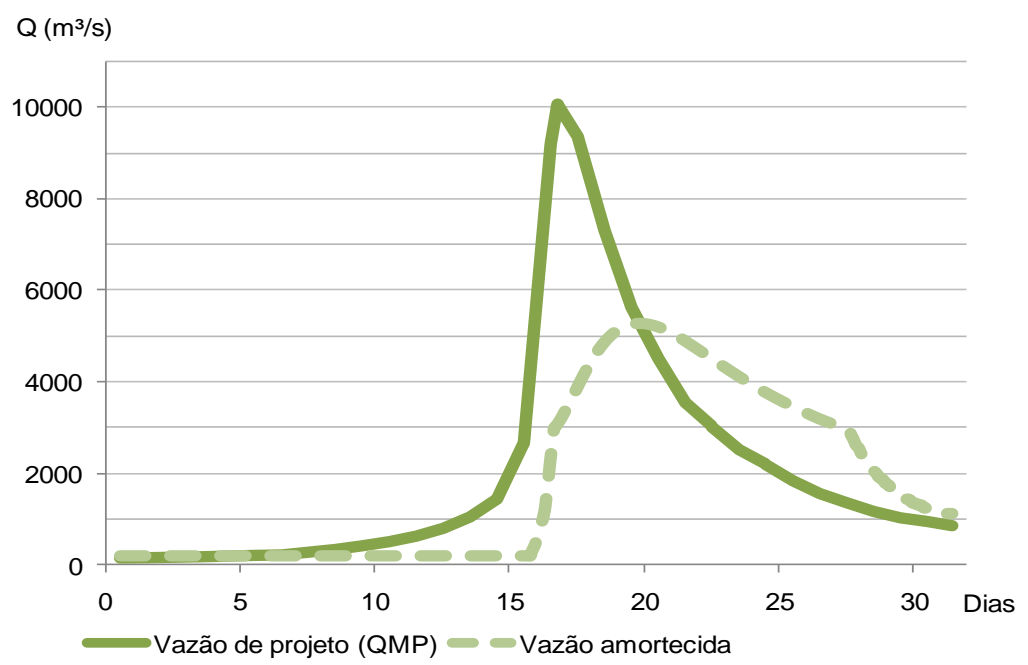

Figura 68 - Amortecimento da cheia de projeto QMP no rio Manso

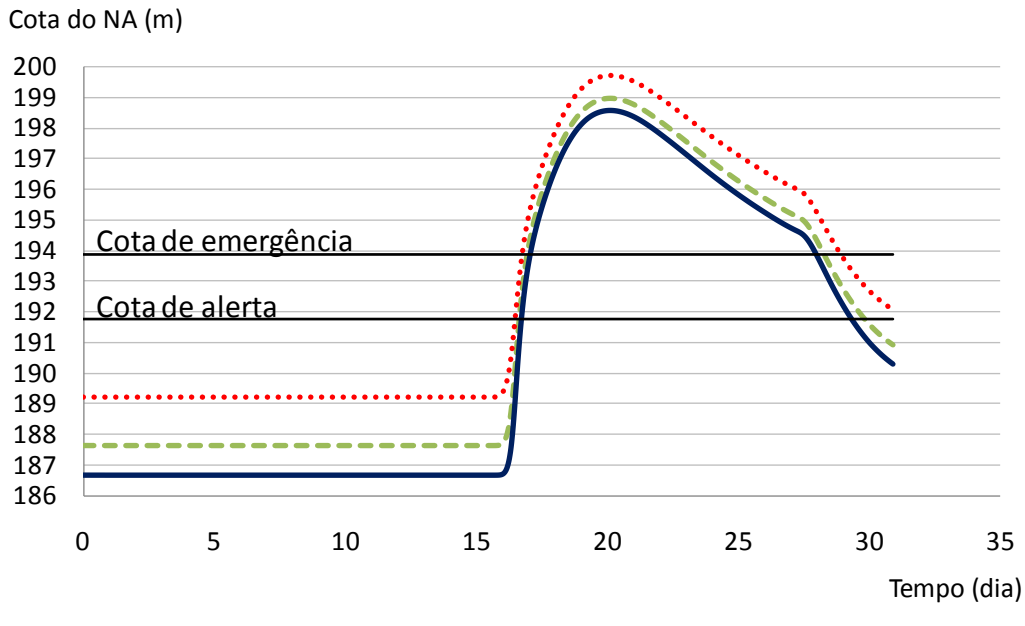

- - Qinc (máx. 198,97 m) …2 x Q Qinc (máx. 199,73 m) —0,5 x Qinc (máx. 198,59 m)

Figura 69 - Cotas Rosário Oeste (QMP)

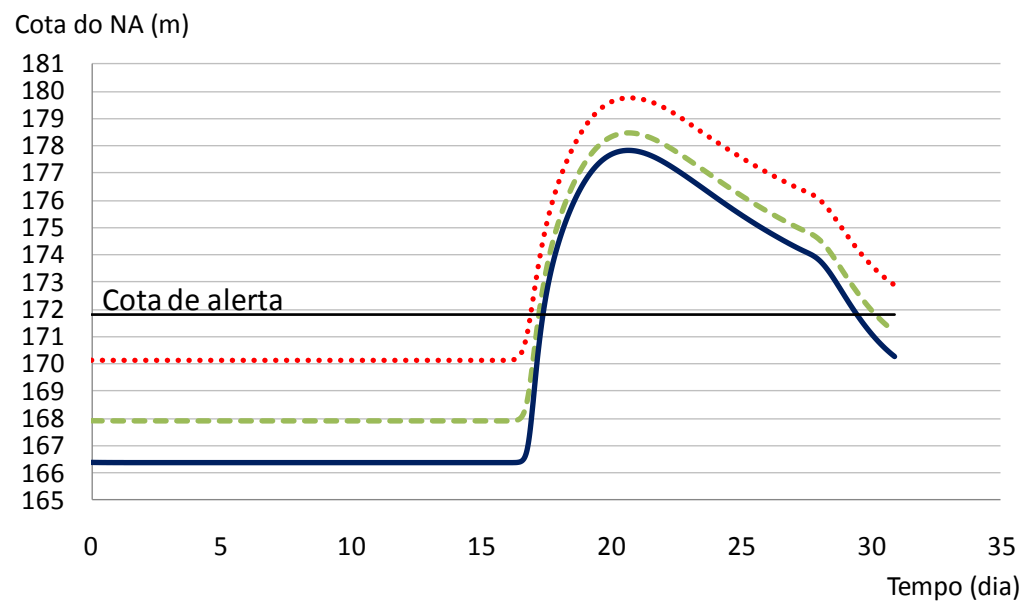

- - Qinc (máx. 178,50 m) …2 x Qinc (máx. 179,78 m) —0,5 x Qinc (máx. 177,85 m)

Figura 70 - Cotas Acorizal (QMP) 


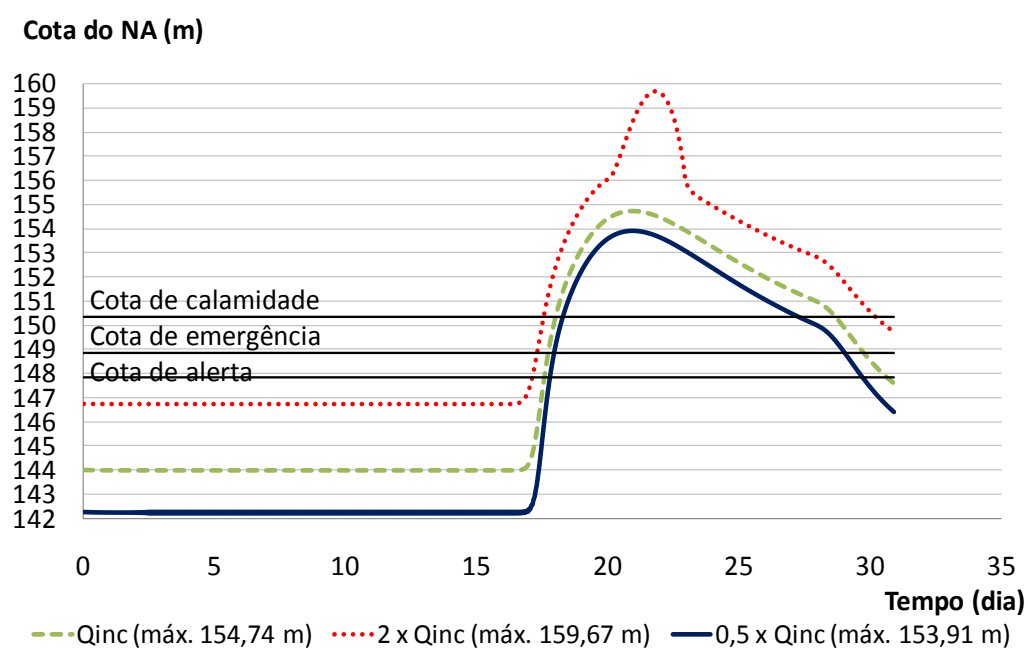

Figura 71 - Cotas Cuiabá (QMP)

A vazão máxima provável a montante do reservatório é estimada em $10.055 \mathrm{~m} 3 / \mathrm{s}$. A capacidade máxima de amortecimento de água reduz a vazão defluente da usina hidrelétrica para $5.290 \mathrm{~m} / \mathrm{s}$, equivalente a $47 \%$ da afluência.

Como esperado, os resultados do cálculo hidrodinâmico apontam níveis de água superiores a qualquer leitura já observada e acima de todas as cotas de segurança, o que indica absoluto extravasamento fluvial. Houve uma deformação nos maiores valores da curva de nível de água de Cuiabá pelo fato de as medições topobatimétricas terem abrangido até aproximadamente a cota ortométrica $156,00 \mathrm{~m}$, a partir da qual a deformação se inicia. Além disso, como a curva-chave foi fixada com níveis de água muito menores, a falta de informação a respeito da vazão em função dessas cotas mais elevadas obriga o modelo matemático adotar a mesma regra da calha fluvial, o que na prática não acontece.

As Figuras 72 a 74 ilustram os níveis de água máximos que seriam atingidos nos municípios Rosário Oeste, Acorizal e Cuiabá para cada uma das cheias de projeto analisadas, considerando a capacidade de amortecimento do reservatório e, como vazão da bacia incremental, as três vazões específicas examinadas. Esses gráficos são a síntese dos resultados de cálculo hidrodinâmico obtidos no cenário (iii). Deve-se atentar para o fato de que o eixo das abscissas, relativo ao período de retorno, estar em escala logarítmica. 


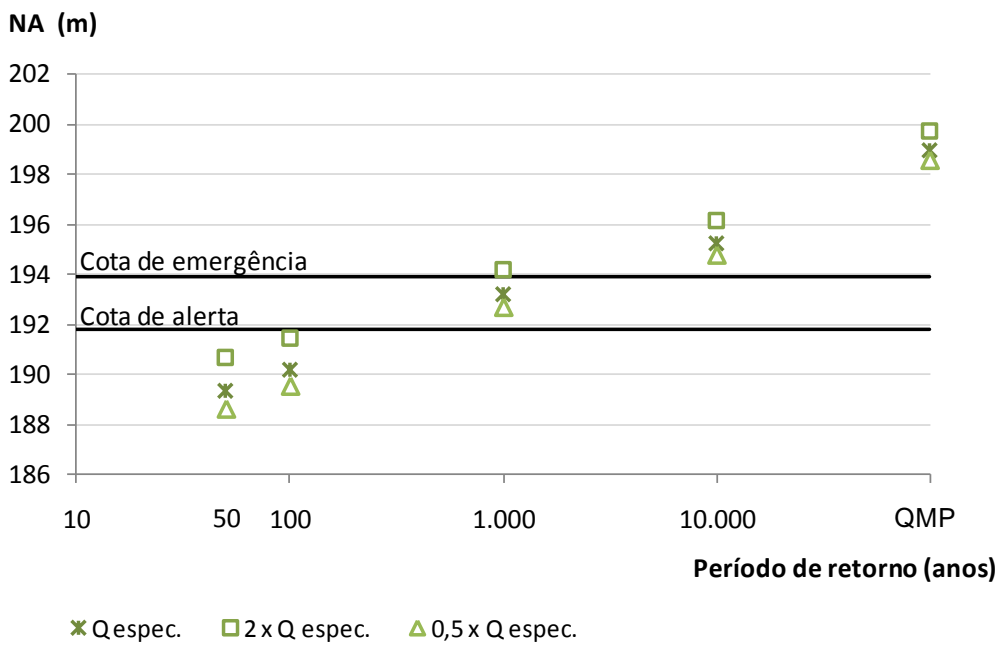

Figura 72 - Níveis de água em Rosário Oeste em função de cheias com diversos períodos de retorno afluente ao APM Manso

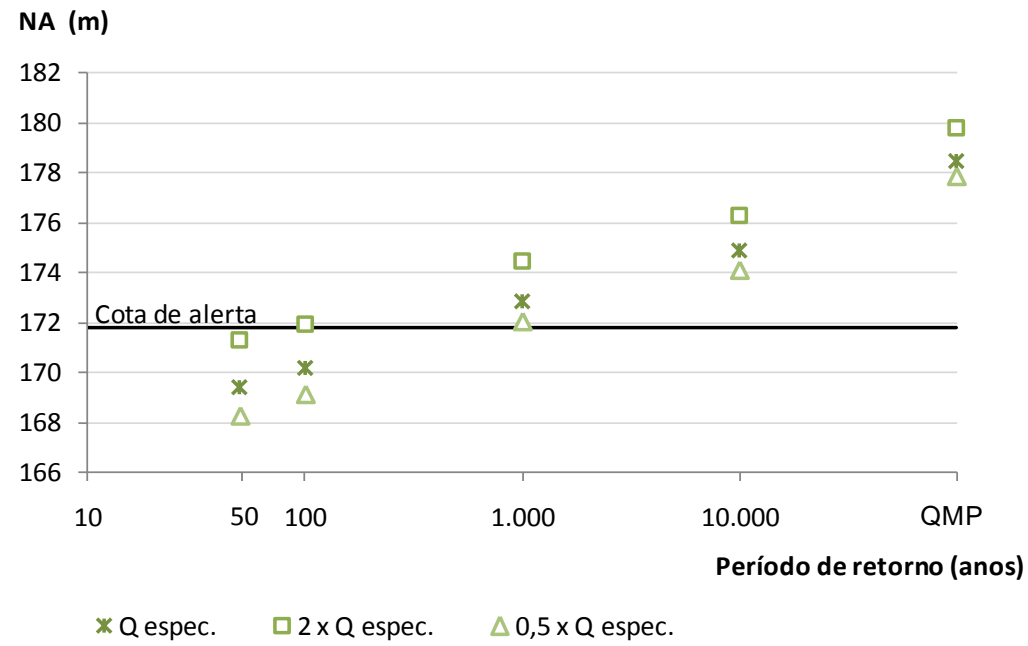

Figura 73 - Níveis de água em Acorizal em função de cheias com diversos períodos de retorno afluente ao APM Manso

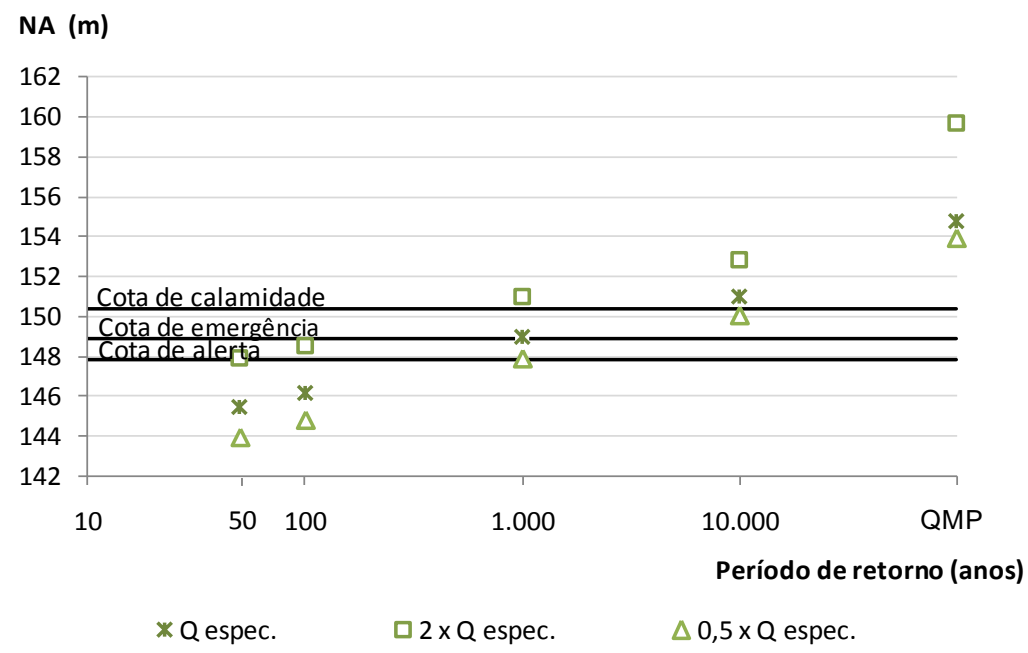

Figura 74 - Níveis de água em Cuiabá em função de cheias com diversos períodos de retorno afluente ao APM Manso 
Em relação às cinco simulações hidrodinâmicas realizadas no cenário (iii), é possível notar que a opção pela vazão específica - correspondente à bacia intermediária entre a UHE Manso e Cuiabá - é essencial para a precisão dos níveis de água nas cidades a jusante da usina. Com a estimativa do amortecimento de Manso e a escolha da menor vazão específica entre as examinadas, a cota de alerta passaria a ser atingida em Cuiabá em cheias pouco abaixo daquelas com TR 1.000 anos; cota essa que seria alcançada com TR 50 anos se utilizada a maior entre as vazões específicas testadas. Em idênticas condições, a mesma cota só seria atingida em Acorizal com cheias equivalentes a TR 100 anos, e em Rosário Oeste, pouco acima dessa recorrência. Entretanto, ao acatar a menor entre as vazões específicas, as cotas de alerta nesses dois municípios também são ultrapassadas a partir de cheias pouco inferiores a TR 1.000 anos.

É de extrema importância frisar que todas as vazões específicas empregadas foram baseadas em cheias registradas nas sub-bacias do Alto Cuiabá e do Médio Cuiabá. Assim, apenas a mais alta das vazões específicas (2 x Qinc) dessas sub-bacias seja talvez comparável à menor cheia de projeto analisada (TR 50 anos) na sub-bacia do Manso afluente ao reservatório. Isso significa que a ocorrência de cheias com períodos de retorno críticos análogas em todas as sub-bacias da BHC, certamente resultaria em níveis de água maiores que os assinalados em todas as simulações. 





\section{CONCLUSÕES}

Durante a calibração, foi notado que o modelo CLiv demonstrou insensibilidade à maioria dos parâmetros, e, entre eles, o coeficiente de rugosidade é o que melhor possibilitou o ajuste das curvas. As pequenas variações nos resultados durante essa etapa provavelmente existiu em virtude das proporções dos rios modelados, o que sugere o uso do CLiv preferencialmente em córregos e rios de menores grandezas. De qualquer maneira, a calibração foi considerada satisfatória para o propósito do trabalho, pois, ao invés de valores precisos de nível de água, foram valorizadas dimensões aproximadas desses níveis para que se tivesse noção da capacidade do amortecimento do reservatório de Manso e de sua influência na translação da onda de cheia para estabelecimento dos riscos à população a jusante.

Ao longo desta pesquisa, foram analisados três cenários para a operação do modelo hidrodinâmico, sendo os dois primeiros baseados em informações diretamente observadas na bacia do Cuiabá e o último fundamentado em informações secundárias, como as que determinaram as vazões críticas da sub-bacia de Manso. No primeiro cenário, foi simulada a inexistência do reservatório, em circunstância hipotética em que os municípios a jusante do APM Manso não seriam beneficiados pelo amortecimento das vazões. No segundo e terceiro cenários, a atenuação das cheias existiu em teoria, e o cálculo do amortecimento foi reproduzido a partir de metodologia reconhecida.

No cenário (i) foram avaliadas três das maiores cheias que aconteceram na BHC após o fechamento da barragem da UHE Manso na hipótese de que caso o reservatório de Manso não existisse, as proporções da enchente seriam grandes. Destarte, apesar da conclusão que as ocorrências de 2002 e 2004 não assumiriam grandes magnitudes, foi averiguado que a cheia de 2006 atingiria as cotas de segurança, inclusive as de emergência em Rosário Oeste e Cuiabá; e que o reservatório foi capaz de amortecê-la eficazmente.

As cheias que provocaram as três inundações de maior prejuízo na BHC foram avaliadas no cenário (ii) para apurar se o amortecimento proporcionado pelo APM Manso seria suficiente para que não houvesse tais danos. Em todas as situações examinadas, o reservatório permitiria a redução dos níveis de água máximos, embora na cheia de janeiro de 1995 os níveis ainda atingiriam a cota de alerta nos três municípios estudados. Todavia, os maiores picos em Cuiabá ocorreram em março de 1974 e em fevereiro de 1995, e neles os 
níveis de água se manteriam abaixo da cota de alerta. A razão pela qual os maiores níveis de água observados (março de 1974 e fevereiro de 1995) serem reduzidos a valores inferiores à cota de alerta após o amortecimento, enquanto a cheia de janeiro de 1995 continuaria superior a essa cota, advém do fato de o volume do hidrograma desta cheia ser maior que o das outras duas, o que limitou o volume de espera do reservatório durante cada amortecimento.

No cenário (iii) cinco cheias críticas de projeto da sub-bacia do Manso afluente ao reservatório foram utilizadas para avaliar o potencial do amortecimento e a sua consequência a jusante, considerando três possibilidades de vazões incrementais da bacia intermediária, nomeadas neste trabalho de vazão específica, que significa a vazão por unidade de comprimento do rio principal. Foi verificado que cheias com período de retorno de aproximadamente 50 anos são suficientes para atingir a cota de alerta em Cuiabá, se forem atribuídas as maiores vazões específicas; e a partir de períodos de retorno de aproximadamente 100 anos o mesmo acontece em Rosário Oeste e Acorizal. Cabe ressaltar que em Cuiabá, mesmo quando registrados níveis de água inferiores a essa cota, são relatados casos de inundação em algumas comunidades, seja pelo rio Cuiabá ou pelos afluentes urbanos remansados. A escolha da menor vazão específica resultou no alcance das cotas de alerta dos três municípios em cheias com tempo de recorrência de aproximadamente 1.000 anos. Estas cheias são suficientes para superar todas as cotas de segurança se a opção for a vazão específica mais elevada entre as três. Com adoção da maior vazão específica e plena confiança no amortecimento do reservatório de Manso, as simulações realizadas indicaram que as cheias ocorridas em março de 1974 e em fevereiro de 1995 se repetiriam com tempo de recorrência pouco superior a 100 anos; e a de janeiro de 1995, pouco inferior a esse período.

Como relatado, os valores das vazões específicas são baseados em cheias reais na BHC, os quais são carregados no modelo hidrodinâmico ao lado das cheias críticas de projeto da sub-bacia do Manso, que são valores baseados em teoria probabilística. Por esse motivo, em relação às simulações do cenário (iii), a vazão específica mais elevada deve receber maior atenção, já que esta se adequa melhor à concepção de bacias vizinhas apresentarem cheias com períodos de retorno semelhantes.

Em todos os cenários, ficou evidente que a escolha das vazões específicas é essencial para a precisão da definição da altura do rio nas seções topobatimétricas, e que suas variações representam grande alteração nos níveis de água em cada município. A sensibilidade existe em virtude da vasta área entre a usina e as cidades estudadas. O comprimento longitudinal dos rios Manso e Cuiabá, no percurso da usina até a capital mato-grossense, é de $285 \mathrm{~km}$; e a área 
incremental possui $14.200 \mathrm{~km}^{2}$, a qual representa $60 \%$ da BHC até Cuiabá. Essa extensão dificulta tanto a estimativa da contribuição relativa à área intermediária quanto a operação do reservatório de Manso se ela tiver por objetivo a regularização de vazões a jusante.

A dificuldade quanto à indefinição da vazão específica advém da falta de informações a respeito das cheias críticas na bacia intermediária. Tal questão poderia ser solucionada com a aplicação de um modelo hidrológico tipo precipitação-vazão. A partir de dados hidrometeorológicos, morfopedológicos e de uso e ocupação da bacia seria possível estimar as vazões intermediárias para que fossem carregadas em cada seção topobatimétrica de maneira autônoma. O emprego do modelo chuva-vazão eliminaria a necessidade de utilizar a vazão específica para suprir a falta de informações a respeito das contribuições intermediárias, e, consequentemente, melhoraria a exatidão dos cálculos finais do modelo hidrodinâmico.

A apreciação dos resultados indica que o reservatório de Manso tem importante papel na atenuação de enchentes na BHC, pelo menos até o município de Cuiabá, e que muitas cheias, porém não todas, podem ser evitadas em decorrência do seu amortecimento. De maneira sucinta, o APM Manso é capaz de aumentar o tempo entre duas grandes inundações, e, portanto reduzir a frequência desses acontecimentos. No entanto, essa capacidade é limitada pelo volume de espera do reservatório, assim, em algumas circunstâncias as inundações se tornam inevitáveis.

Em síntese, o que não é racional é esperar que todos os problemas sejam resolvidos unicamente pelo amortecimento proporcionado pelo reservatório da UHE Manso sem que sejam tomadas outras medidas, sejam elas de cunho estrutural ou de planejamento, e que objetivem a ocupação apropriada do solo e a mitigação dos impactos à população. 





\section{SUGESTÕES}

Apesar de os municípios de Rosário Oeste, Acorizal e Cuiabá terem sido o foco principal neste trabalho, outras cidades a jusante, como Santo Antônio do Leverger e Barão de Melgaço, também são constantemente atingidas pelas inundações deste rio. Sendo assim, e considerando que já existem estações fluviométricas nessas cidades, é sugerido que os estudos sobre as enchentes na BHC se estendam a essas localidades. Porém, para tanto, devem ser observadas as extravasões laterais, que passam a ganhar muita importância a partir da capital do estado pelo fato de as planícies pantaneiras começarem a ser mais constantes.

Uma das conclusões deste trabalho foi em relação à importância da determinação da contribuição intermediária entre a UHE Manso e os municípios estudados. O aperfeiçoamento da obtenção dessas vazões pode ser conseguido através da aplicação de um modelo hidrológico chuva-vazão. Dessa forma, por meio de dados de entrada que caracterizam os fenômenos do ciclo hidrológico, especialmente a precipitação, associados a informações geográficas e de ocupação do solo, as vazões dos corpos hídricos podem ser obtidas nas diversas condições climatológicas. Para a melhoria do conhecimento sobre o comportamento da BHC, é recomendado, portanto, que haja a integração de um modelo hidrológico chuvavazão, capaz de fornecer informações sobre a vazão da bacia incremental, e um hidrodinâmico, responsável pelo cálculo da translação da onda de cheia no trajeto fluvial. Essa talvez tenha sido a principal dificuldade no desenvolvimento da corrente pesquisa. Com essa integração, por conseguinte, as investigações sobre inundações na BHC serão melhor fundamentadas. Alguns dos modelos hidrológicos do tipo chuva-vazão mais utilizados no Brasil são o SMAP, o MGB-IPH, o HEC-HMS e o SWMM.

A complementação do trabalho sobre inundações poderia ser realizada com a geração de mapas de inundação na BHC, a partir dos quais, munidos de dados topográficos, as cheias são visualidades em função dos períodos de retorno avaliados, ou das cheias já observadas, considerando ou não o amortecimento proporcionado pelo reservatório.

O desenvolvimento das técnicas de modelagem matemática pode se tornar ineficaz caso os dados que os alimentam sejam demasiadamente generalizados e incompatíveis com a sua qualidade. Portanto, é imprescindível que haja melhoria das informações hidráulicas e hidrológicas. Em relação ao aprimoramento de informações primordiais à $\mathrm{BHC}$, é sugerida a 
expansão da rede fluviométrica, tanto em termos quantitativos quanto qualitativos, com várias leituras diárias e telemetria, especialmente nas principais estações, de tal modo que não sejam necessárias as generalizações utilizadas nesta dissertação em trabalhos posteriores. Outra carência de informações é quanto à disponibilidade de dados topográficos sobre a BHC de forma a permitir que a sua discretização seja coerente com os objetos de estudos hidráulicohidrológicos. O ideal é que os mapas sejam elaborados com curvas de nível a cada metro; porém, dentro das condições admissíveis, ótimos resultados já podem ser obtidos com curvas de nível a cada $5 \mathrm{~m}$ na zona urbana e pouco mais na zona rural. É necessário, também, o acréscimo de levantamentos topobatimétricos nos principais rios da $\mathrm{BHC}$, com seções distanciadas entre 5 e $10 \mathrm{~km}$, pelo menos, para que os modelos matemáticos não precisem interpolar exageradamente as declividades, e para que haja possibilidade de examinar as vazões e níveis de água em cada uma dessas seções intermediárias. Por fim, a atualização das curvas-chave nas principais seções da bacia do rio Cuiabá, a começar pela da capital matogrossense, é importante para a precisão dos dados de vazão. Como já explicado, as calhas fluviais são modificadas com o passar do tempo em muitos pontos dos rios da BHC.

Nos últimos anos foram observados alguns problemas relacionados às cotas de segurança estipuladas pela SUDEC/MT em 1974. Determinadas comunidades têm sido atingidas quer pelo rio principal ou pelos afluentes remansados mesmo quando o nível de alerta não é alcançado. Assim, sugere-se a revisão desse limite de referência, tendo em consideração as novas ocupações urbanas e os comportamentos dos sistemas hídricos que influenciam o meio urbano. São aconselhados, também, estudos voltados a esses córregos, tanto no que compete à ocupação das suas áreas de preservação permanente quanto no que diz respeito às situações de danos que as cheias desses corpos hídricos podem causar.

A conclusão geral da presente pesquisa aponta que o amortecimento do APM Manso é capaz de amenizar consideravelmente as cheias nas comunidades a jusante do reservatório, pelo menos até o município de Cuiabá, porém, foi constatado que a eficácia é limitada. Assim, é extremamente importante que as comunidades influenciadas pelas águas do rio Cuiabá assumam a responsabilidade sobre a segurança de seus habitantes, e, mais que respeitar a lei, respeitem os condicionantes que os corpos hídricos impõem ao meio. 


\section{REFERÊNCIAS BIBLIOGRÁFICAS}

ABBOTT, M. B. (1979). Computational hydraulics. London: Pitman Publishing. 324p.

ALLASIA (2007). Avaliação da previsibilidade hidroclimática no Alto Paraguai. Tese de Doutorado pelo Programa de Pós-Graduação em Recursos Hídricos e Saneamento Ambiental: UFRGS. Porto Alegre, RS. 342p.

ANA - Agência Nacional de Águas. Sistema de Informações Hidrológicas - Hidroweb. Disponível em: <www.ana.gov.br>. Acesso em: 15 de set de 2009.

ANA/GEF/PNUMA/OEA. (2005). Modelo de simulação hidrológica na bacia do Alto Paraguai. Projeto implementação de práticas de gerenciamento integrado de bacia hidrográfica para o pantanal e bacia do Alto Paraguai. Subprojeto 5.4 - Modelo Integrado de Gerenciamento Hidrológico da Bacia do Alto Paraguai. Relatório final. Paulo Varella (Coord.). Porto Alegre.

AZEVEDO, L. G. T., PORTO, R. L. L.; ZAHED FILHO, K. (2002). Modelos de Simulação e de Rede de Fluxo. In: PORTO, R. L. L (Org.). Técnicas quantitativas para o gerenciamento de recursos hídricos. $2^{\text {a }}$ Ed. Porto Alegre: Editora da UFRGS e ABRH. Cap. 4. p. 165-227.

BARROS, M. T. L. (2002). Gerenciamento integrado de bacias hidrografias em áreas urbanas. Projeto: $02-$ Ciamb - 01/97 - 03/01-2. PADCTIII. CNPq. $3^{\circ}$ relatório parcial.

BARROS, M. T. L. (2004). Sistema de suporte a decisões aplicado a gestão e planejamento de recursos hídricos. Relatório final. EPUSP. São Paulo. 246p.

BARROS, M. L. T.; ZAMBON, R. C.; PORTO, R. L. L. (2009). Amortecimento de ondas de cheias em reservatórios. Material didático. PHD 5013 - Hidrologia determinística. Departamento de engenharia hidráulica e sanitária. EPUSP.

BEVEN, K. J. (2001). How far can we go in distributed hydrological modeling? Hydrology and Earth System Sciences. 5 (1), p. 1-12.

BRASIL (1965). Lei Federal n. ${ }^{\circ} 4771$ de 1965. Institui o Novo Código Florestal. Publicado no Diário Oficial da União em 16 de setembro de 1965. Brasília, DF.

(1979). Lei Federal n. ${ }^{\circ} 6.766$ de 1979. Dispõe sobre o Parcelamento do Solo Urbano e dá outras Providências. Publicado no Diário Oficial da União em 20 de dezembro de 1979. Brasília, DF.

(1986). Ministério do Meio Ambiente. Conama - Conselho Nacional do Meio Ambiente. Resolução n. ${ }^{\circ} 001$ de 1986. Estabelece as definições, as responsabilidades, os critérios básicos e as diretrizes gerais para uso e implementação da Avaliação de Impacto Ambiental. Publicado no Diário Oficial da União em 17 de fevereiro de 1986. Brasília, DF. 
(1997a). Lei n 9.433 de 8 de janeiro de 1997. Institui a Política Nacional de Recursos Hídricos, cria o Sistema Nacional de Gerenciamento de Recursos Hídricos, regulamenta o inciso XIX do art. 21 da Constituição Federal, e altera o art. $1^{\circ}$ da Lei ${ }^{\circ} 8.001$, de 13 de março de 1990, que modificou a Lei $\mathrm{n}^{\circ} 7.990$, de 28 de dezembro de 1989. Publicado no Diário Oficial da União. em 9 de jan de 1997. Brasília, DF.

(1997b). Ministério do Meio Ambiente, dos Recursos Hídricos e da Amazônia Legal. Secretaria de Coordenação dos Assuntos de Meio Ambiente. Programa Nacional do Meio Ambiente. Plano de conservação da Bacia do Alto Paraguai (Pantanal): PCBAP. Análise integrada e prognóstico da bacia do Alto Paraguai. Brasília, DF: PNMA, 1997. 12v. il.

(2007) Ministério das Cidades / Instituto de Pesquisas Tecnológicas - IPT. Mapeamento de riscos e encostas e margens de rios. Celso Santos Carvalho, Eduardo Soares de Macedo e Agostinho Tadashi Ogura (Orgs.). Brasília: Ministério das Cidades; Instituto de Pesquisas Tecnológicas - IPT.

(2010a). Lei Federal n. ${ }^{\circ} 12.334$ de 2010. Estabelece a Política Nacional de Segurança de Barragens destinadas à acumulação de água para quaisquer usos, à disposição final ou temporária de rejeitos e à acumulação de resíduos industriais, cria o Sistema Nacional de Informações sobre Segurança de Barragens e altera a redação do art. 35 da Lei no 9.433, de 8 de janeiro de 1997, e do art. 4o da Lei no 9.984, de 17 de julho de 2000. Publicado no Diário Oficial da União em 21 de setembro de 2010. Brasília, DF.

(2010b). Lei n. ${ }^{\circ} 7.257$ de 2010. Regulamenta a Medida Provisória no 494 de 2 de julho de 2010, para dispor sobre o Sistema Nacional de Defesa Civil - SINDEC, sobre o reconhecimento de situação de emergência e estado de calamidade pública, sobre as transferências de recursos para ações de socorro, assistência às vítimas, restabelecimento de serviços essenciais e reconstrução nas áreas atingidas por desastre, e dá outras providências. Publicado no Diário Oficial da União em 5 de agosto de 2010. Brasília, DF.

(2010c). Ministério das Minas e Energia. Companhia de Pesquisa de Recursos Minerais - CPRM. Previsão hidrológica e alerta de enchentes - Pantanal Mato-grossense. 11 p. Disponível em: <http://www.cprm.gov.br/publique/media/prev.pdf >. Acesso em $17 \mathrm{dez}$ 2010.

(2010d). Agência Nacional de Energia Elétrica - ANEEL, Agência Nacional de Águas - ANA. Resolução Conjunta n. ${ }^{\circ} 03$ de 2010. Estabelecer as condições e os procedimentos a serem observados pelos concessionários e autorizados de geração de energia hidrelétrica para a instalação, operação e manutenção de estações hidrométricas visando ao monitoramento pluviométrico, limnimétrico, fluviométrico, sedimentométrico e de qualidade da água associado a aproveitamentos hidrelétricos, e dar outras providências. Publicado no Diário Oficial da União em 20 de outubro de 2010. Brasília, DF.

BRANDÃO, J. L. B.; BARROS, M. T. L. (2007). Determinação de áreas de inundação para uma bacia urbana. In: Anais do Simpósio de hidráulica e recursos hídricos dos países de língua oficial portuguesa. São Paulo: ABRH. p. 1-13.

BRANDÃO, J. L. B. (2010). Amortecimento de cheias em reservatórios. Material didático. SHS 0360 - Recursos hídricos. Departamento de hidráulica e saneamento. EESC/USP.

BUTLER, S. S. (1957). Engineering Hydrology. Ed. Prentice-Hall, N.J. 356p. 
CALHEIROS, D. F.; ARNDT, E.; RODRIGUES, D. O.; SILVA, M. C. A. (2009). Influências de usinas hidrelétricas no funcionamento hidro-ecológico do Pantanal matogrossense - Recomendações [recurso eletrônico]. Corumbá: Embrapa Pantanal. Disponível em: <http:// www.cpap.embrapa.br/publicacoes/online/DOC102.pdf>. Acesso em: 27 fev 2010 .

CARTA GEOTÉCNICA DE CUIABÁ. (1990) Universidade Federal de Mato Grosso UFMT / Prefeitura Municipal de Cuiabá. Carta Geotécnica de Cuiabá - Módulo I. Cuiabá, MT.

CASTELlARIN, A.; DI BALDASSARRE, G.; BATES, P. D.; BRATH, A. (2009). Optimal Cross-Sectional Spacing in Preissmann Scheme 1D Hydrodynamic Models. J. Hydr. Engrg. Vol.135. 96-105p. DOI:10.1061/(ASCE)0733-9429(2009)135:2(96).

CUIABÁ. (1999). IPDU - Instituto de Planejamento e Desenvolvimento Urbano de Cuiabá. Diretoria de Pesquisa e Informação - DPI. Prefeitura Municipal de Cuiabá. Estimativa da população e domicílios em áreas inundáveis. Cuiabá, MT.

(2007a). Lei Complementar n. 150 de 2007. Dispõe sobre o Plano Diretor de Desenvolvimento Estratégico de Cuiabá e dá outras providências. Publicada na Gazeta Municipal n. ${ }^{\circ} 128$ de 2 de fevereiro de 2007. Cuiabá, MT.

(2007b). IPDU - Instituto de Planejamento e Desenvolvimento Urbano de Cuiabá. Diretoria de Pesquisa e Informação - DPI. Prefeitura Municipal de Cuiabá. Perfil socioeconômico dos bairros de Cuiabá. Disponível em: <http://www.cuiaba.mt.gov.br/ upload/arquivo/perfil_dos_bairros.pdf>. Acesso em: 10 fev 2011. Cuiabá, MT. 124p.

(2009). IPDU - Instituto de Planejamento e Desenvolvimento Urbano de Cuiabá. Perfil Socioeconômico de Cuiabá. Vol IV. Cuiabá: Central de Textos.

CHOW, V. T. (1959). Open channel hydraulics. New York: McGraw-Hill. 680p.

CHOW, V. T., MAIDMENT, D. R., MAYS, L. W. (1988). Applied Hydrology. Singapure: McGraw-Hill.

CUNDERLIK, J. M.; SIMONOVIC, S. P. (2004). Calibration, verification, and sensitivity analysis of the HEC-HMS hydrological model. Water Resources Research Report N. 048. Facility for Intelligent Decision Support. Department of Civil and Environmental Engineering. London, Ontario, Canada.

CUNGE, J. A., HOLLY, F. M., VERWEY, A. (1980). Practical aspects of computatiuonal river hydraulics. Pitman Publishing, London. 420p.

ENGECORPS/HARZA. (2000). Projeto de transposição de águas do rio São Francisco para o Nordeste setentrional. Relatório R12. Engecorps/Harza. São Paulo. 2000. 289p

FCTH (2003) - Fundação Centro Tecnológico de Hidráulica.. CLiv - Software para simulação de escoamentos em condutos livres: manual do usuário. Universidade de São Paulo, São Paulo, 109p. Disponível em: 〈http://www.fcth.br/pub/softwares/manual_cliv.pdf〉. Acesso em 17 mar 2010. 
FIGUEIREDO, D. M.; SALOMÃO, F. X. T. (2009). Bacia do Rio Cuiabá: Uma abordagem socioambiental. Cuiabá: Entrelinhas: EdUFMT.

FREAD, D.L. 1992. Flow Routing. In: MAIDMENT. D. R. (ed.) Handbook of Hydrology. New York: McGraw-Hill.

FURNAS (2002). Furnas Centrais Elétricas S. A. Aproveitamento Múltiplo Manso Memória técnica. Rio de Janeiro - RJ.

FURNAS (2008). Furnas Centrais Elétricas S. A. Ofício CJ.P.E.074.2008. Rio de Janeiro. Ofício em resposta ao ofício GP n. ${ }^{\circ} 316$ que solicita manifestação técnica da empresa quanto à interferência do Aproveitamento Múltiplo de Manso no controle das cheias do rio Cuiabá nos limites deste município. 2p.

GETIRANA, A. C. V. (2005) Análise de soluções de conflitos pelo uso da água no setor agrícola através de técnicas de PL. Tese de Mestrado pelo Programa de Pós-Graduação em Engenharia Civil: COOPE/UFRJ. Rio de Janeiro, RJ. 140p.

HERNANDEZ, V. (2007). Propagação de enchentes em reservatórios - Método direto. RBRH - Revista Brasileira de Recursos Hídricos. Vol. 12. n. 2. Abr-Jun/2007. p. 115-122.

HUNTER, N. M.; BATES, P. D.; HORRITT, M.S.; WILSON, M. D. (2007). Simple spatially-distributed models for predicting flood inundation: a review. Geomorphology. Volume 90. p. 208-225. DOI: 10.1016/j.geomorph.2006.10.021.

IBGE - Instituto Brasileiro de Geografia e Estatística. Cidades@. Disponível em: <http://www.ibge.gov.br/cidadesat/topwindow.htm?1>. Acesso em: 11 nov 2010.

ISDR. (2005). International Strategy for Disaster Reduction. 2005 disaster in numbers. Disponível em: 〈http://www.unisdr.org/disaster-statistics/pdf/2005-disaster-in-numbers.pdf>. Acesso em: 23 fev 2011.

JORDÃO, A. (2006). Defesa civil e Furnas garantem a prefeito que a situação está sob controle. Comunicação da Prefeitura Municipal de Cuiabá. 19 de março de 2006. Disponível em: <www.cuiaba.mt.gov.br/noticia.jsp?id=2428>. Acesso em 23 jan 2010.

LIBOS, M. I. P. C.; ROTUNNO FILHO, O.C; ZEILHOFER, P. (2003). Modelagem da poluição não pontual na bacia do rio Cuiabá baseada em geoprocessamento. RBRH Revista Brasileira de Recursos Hídricos. Vol. 8. n. 4. Out-Dez/2003. p. 115-135.

LIBOS, M. I. P. C. (2008). Modelagem hidrológica quali-quantitativa: estudo de caso da bacia hidrográfica do rio Manso - MT. Tese de Doutorado pelo Programa de PósGraduação em Engenharia Civil: COOPE/UFRJ.. Rio de Janeiro, RJ.

LIMA, D. R. O. (2005). Diagnóstico de chuvas e previsão meteorológica para a bacia hidrográfica do rio Manso. Tese de Mestrado pelo Programa de Pós-Graduação em Engenharia Civil: COOPE/UFRJ. Rio de Janeiro, RJ.

LIMA, E. B. N. R. (2001). Modelagem Integrada para Gestão da Qualidade da Água na Bacia do Rio Cuiabá. Tese de Doutorado pelo Programa de Engenharia Civil: COPPE/UFRJ. Rio de Janeiro, RJ. 
LOU, R. F. (2010). Modelagem hidrológica chuva-vazão e hidrodinâmica aplicada na bacia experimental do rio Piabanha/RJ. Dissertação de mestrado pelo Programa de PósGraduação em Engenharia Civil. COPPE/UFRJ. Rio de Janeiro, RJ. 174p.

MAIDMENT, D. R. (1993). GIS and hydrologic modeling. In: GOODCHILD, M. F.; PARKS, B. O.; STEYAERT, L. T. (Ed.) Environmental modeling with GIS. New York: Oxford University Press. Cap. 14, p. 147-167.

MATO GROSSO. Superintendência da Defesa Civil do estado de Mato Grosso SUDEC/MT. Disponível em: <http://www.defesacivil.mt.gov.br/default.aspx>. Acesso em 27 julho 2010.

MATO GROSSO (2009). Lei Complementar n. 359 de 2009. Dispõe sobre a criação da região metropolitana do Vale do Rio Cuiabá e dá outras providências. Publicado no Diário Oficial n. ${ }^{\circ} 25.084$ de 27 de maio de 2009. Cuiabá, MT

MOURA, R. M. P. (2006). Análise ambiental da APM-Manso e propostas para uma operação ecológica. Dissertação de Mestrado pelo Programa de Pós-Graduação em Geografia: ICHS/UFMT. Cuiabá, MT. 94p.

MUSIS, C. R. (1997). Caracterização Climatológica da Bacia do Alto Paraguai. Tese de Mestrado pelo Programa de Pós-Graduação em Agricultura Tropical: FAMEV/UFMT. Cuiabá, MT.

NASCIMENTO, L. S. V; REIS JR, D. S.; MARTINS, E. S. P. R. (2009). Avaliação do algoritmo evolutivo Mopso na calibração multiobjetivo do modelo SMAP no estado do Ceará. Revista Brasileira de Recursos Hídricos. Vol. 14. n.1. Jan/Mar 2009, p. 85-97.

OLIVEIRA, L. C. (2003). Papel do monitoramento e da previsão de vazões no gerenciamento de bacias hidrográficas. Tese de Mestrado pelo Programa de Pós-Graduação em Engenharia Civil: COOPE/UFRJ . Rio de Janeiro, RJ.

ONO, S. (2008). Sistema de suporte a decisão para gestão de água urbana - URBSSD. Dissertação de Mestrado pelo Programa de Pós-Graduação em Engenharia Civil: EPUSP. São Paulo, SP.

PALMIER, L.R.; BRASIL, L. S. S.; MONTE-MOR, R. C.; NASCIMENTO, N.; ROCHA, E.G.; E SILVA, N. S.; CANELLAS, A. V. B. (2007). Modelagem simplificada de onda de cheia proveniente de ruptura hipotética de barragem - estudo de caso: barragem do Aproveitamento Múltiplo Manso, Mato Grosso, Brasil. I Simpósio de Recursos Hídricos do Centro-Oeste. Cuiabá, MT. 17p.

PAZ, A. R. (2010). Simulação hidrológica de rios com grandes planícies de inundação. Tese de Doutorado pelo Programa de Pós-Graduação em Recursos Hídricos e Saneamento Ambiental: UFRGS. Porto Alegre, RS. 235p.

PEDROLLO, J.M.; DE PAES, R.P. (2011). Enchentes do rio Cuiabá e sua relação com a ocupação do solo urbano. Artigo a ser publicado. Cuiabá, MT. 
PORTO, R. L. L; AZEVEDO, L. G. T. (2002). Sistemas de Suporte a Decisões Aplicados a Problemas de Recursos Hídricos. In: PORTO, R. L. L. (Org.). Técnicas quantitativas para o gerenciamento de recursos hídricos. $2^{\text {a }}$ Ed. Porto Alegre: Editora da UFRGS e ABRH. Cap. 2. p. $15-41$.

PORTO, R. L. L.; ZAHED FILHO, K.; DOURADO, S. S. S.; OLIVEIRA, C. P. M. (2007). Amortecimento de ondas de cheia em reservatório. Material didático. PHD 2307 Hidrologia aplicada. Departamento de engenharia hidráulica e sanitária. EPUSP.

PORTO, R. M. (2006). Hidráulica básica. $4^{a}$ Ed. São Carlos: EESC/USP.

PRAMANIK, N., PANDA, R. K., SEN, D. (2009). One dimensional hydrodynamic modeling of river flow using DEM extracted river cross-sections. Water Resources Management. Earth and Environmental Science. DOI: 10.1007/s11269-009-9474-6. Springer Netherlands Pub. Vol. 24. n. ${ }^{\circ}$ 5. p. 835-852.

PULS, L. G. (1928). Flood Regulation of the Tennessee River. House Document. N. ${ }^{\circ} 185$, 70th Congress, st Session, U.S. Government Printing Office, Washington, D.C. pt.2. Appendix B.

REFSGAARD, J.C. (2001). Towards a formal approach to calibration and validation of models using spatial data. In: GRAYSON, R.B.; BLÖSCHL, G. (Eds.). Spatial Patterns in Catchment Hydrology: Observations and Modeling. Cambridge University Press: Cambridge. p. 329-354.

SAAF. (2003) Secretaria de Agricultura e Assuntos Fundiários do Estado de Mato Grosso. Diagnóstico da bacia hidrográfica do Rio Cuiabá. Relatório final de diagnóstico ambiental realizado pela empresa Ecoplan. Porto Alegre, RS.

SALOMÃO, F. X. T. (1999). Rio Cuiabá: a geologia e a problemática da erosão e do assoreamento. In: FERREIRA, M. S. F. D. (Org.). O rio Cuiabá como subsídio para a educação ambiental. Cuiabá: EdUFMT. Cap. 2.

SAMUELS, P. G. (1990). Cross-section location in 1-D models. In: Proceedings of $\mathbf{1}^{\text {st }}$ International Conference on River Flood Hydraulics.. WHITE, W. R. (Ed.). Wiley, Chinchester, United Kingdom. p. 339-350.

SCHARDONG, A; SIMONOVIC, S. P.; GARCIA, J. I. B; PORTO, R. L. L. (2009). Comparação de algoritmos evolucionários na calibração de modelo chuva-vazão SMAP. XVIII Simpósio Brasileiro de Recuros Hídricos. Campo Grande, MS. 20p.

SHIRASHI, F. K. (2003). Avaliação dos efeitos da construção da APM Manso no controle das cheias nas áreas urbanas das cidades de Cuiabá e Várzea Grande - MT. Tese de Mestrado pelo Programa de Pós-Graduação em Engenharia Civil: COOPE/UFRJ. Rio de Janeiro, RJ.

SILVA, D. L. M.; BRAGA, R. S. (2000). Sistema de monitoramento hidrológico durante a fase de enchimento do reservatório do APM Manso. In: Anais I Simpósio de Recursos Hídricos do Centro Oeste. Brasília, DF. 
SILVA, E. A.; TUCCI, C. E. M. (1998). Relação entre as vazões máximas diária e instantânea. RBRH - Revista Brasileira de Recursos Hídricos. Vol. 3. n. 1. Jan-Mar/1998. p. 133-151.

SILVA, R. A. P. (2006). Sistemas de suporte à tomada de decisões em gerenciamento de cheias. Dissertação de Mestrado pelo Programa de Pós-Graduação em Engenharia Civil: EPUSP. São Paulo, SP.

SOTO, Y. J. M. (2004). A modelagem hidrodinâmica como apoio a tomada de decisão em caso de derrame de oleo na parte interna do complexo estuarino Antonina - Paranaguá - PR. Dissertação de Mestrado pelo Programa de Pós-Graduação em Engenharia de Recursos Hídricos e Ambiental: PPGERHA/UFPR. Curitiba, PR.

SOUZA, C. F.; COLlisCHONN, W.; TUCCI, C. E. M.; ARTHINGTON, A. H. (2009). Preliminary assessment of dam hydrological effects in the Brazilian Pantanal. In: Program \& Abstracts Book of 2009 International Symposium on Ecohydraulics. The International Conference of Science and Information Technologies for Sustainable Management of Aquatic Ecosystems. Concepción. Chile. 11p.

TAN, K. S.; CHIEW, F. H. S.; GRAYSON, R. B. (2007). A steepness index unit volume flood hydrograph approach for sub-daily flow disaggregation. Hydrological Processes. DOI: 10.1002/hyp.6501.Vol.: 21. N. ${ }^{\circ} 20$. p. 2807-2816.

TUCCI, C. E. M. (1993). Hidrologia: Ciência e Aplicação. Porto Alegre: Editora da UFRGS e EDUSP ABRH. 952p.

$678 \mathrm{p}$.

(2005). Modelos Hidrológicos. $2^{\text {a }}$ Ed. Porto Alegre: Editora da UFRGS e ABRH.

VERTESSY, R. A.; HATTON, T. J.; O’SHAUGHNESSY, P. J.; JAYASURIYA, M. D. A. (1993). Predicting water yield from a mountain ash forest catchment using a terrain analysis based catchment model. Journal Hydrology. v. 150. N. 2-4. DOI: 10.1016/00221694(93)90131-R. p. 665-700.

VERWEY, A. (2005). Hydroinformatics support to flood forecasting and flood management. In: The Fourth Inter-Celtic Colloquium on Hydrology and Management of Water Resources. Guimarães, Portugal. 21p.

WALKER, W. E; HARREMOËS, P.; ROTMANS, J.; VAN DER SLUIJS, J. P.; VAN ASSELT, M. B. A.; JANSSEN, P. H. M.; VON KRAUSS, M. P. K. (2003). Defining uncertainty: A conceptual basis for uncertainty management in model-based decision support. Integrated Assessment 4(1):5-17.

WARMINK, J. J.; VAN DER KLIS, H.; BOOIJ, M. J.; HULSCHER, J. M. H. (2011). Identification and quantification of uncertainties in a hydrodynamic river model using expert opinions. Water Resour Manage. v. 25. p. 601-622. DOI 10.1007/s11269-010-9716-7.

WENDLAND, E. (2003). Modelos matemáticos e métodos numéricos em águas subterrâneas. São Paulo: SBMAC, 2003. 95p. 


\subsection{Softwares}

ArcGIS versão 9.2

CLiv 2003 versão 7.3

Google Earth 6.0.0.1735 (beta)

MapGEO 2004

Métrica TopoEVN 6.3.7.5

Micrsoft Office Access 2007

Micrsoft Office Excel 2007

Micrsoft Office Word 2007

PhotoScape versão 3.3

Smart Draw versão 6.0 


\section{APÊNDICES}




\section{APÊNDICE A - Discussões acerca das inundações do rio Cuiabá e sua relação com a ocupação do solo urbano}

Determinadas cheias observadas em Cuiabá durante o século XX - vide Tabela 1 Registros linimétricos com valores superiores ao nível de emergência em Cuiabá (9,50 m) e as cotas ortométricas correspondentes, na página 3 - são dignas de ser confrontadas com algumas entre as que serão apresentadas no cenário (iii) do presente trabalho, onde haverá simulação das cheias de projeto com períodos de retorno extremos. Seguindo um preceito entre o nível de água do rio e o crescimento populacional, tais cheias causaram grandes prejuízos sociais e materiais nas populações da BHC. Como os resultados das inundações costumam ser muito diferentes em função do ano em que acontecem, algumas dessas ocorrências serão comentadas e suas imagens colocadas em paralelo com outras mais recentes para discutir os efeitos que poderiam provocar caso fossem observadas na atualidade.

Durante a cheia de março de 1974, o rio Cuiabá atingiu a cota ortométrica 150,21 m e, como mencionado, inundou grande porção da zona urbana da capital mato-grossense. As Figuras 75 e 76 ilustram, respectivamente, o nível de água do rio em 1974, na avenida 15 de Novembro, em Cuiabá, e a linha aproximada representada por este nível no mesmo local se registrada em 2011.

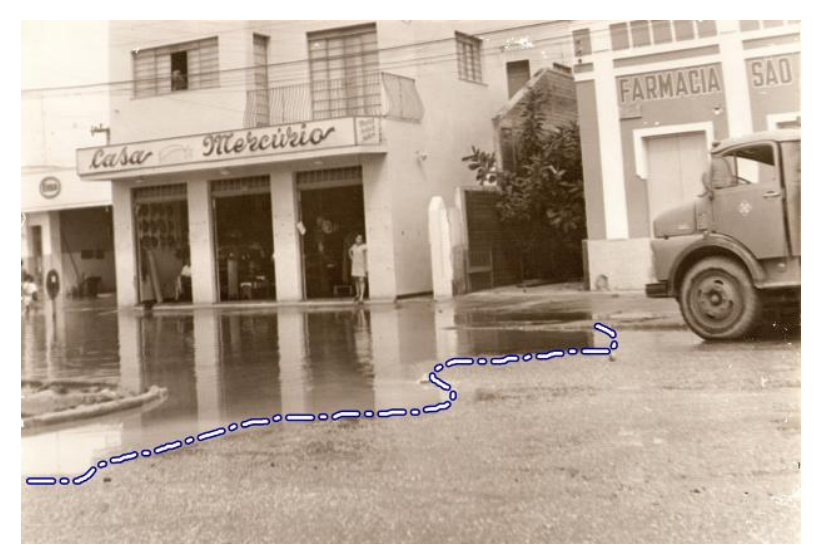

Figura 75 - NA do rio Cuiabá na Av. 15 de Novembro, em Cuiabá (1974)

Fonte: Acervo particular de João C. C. Cardoso

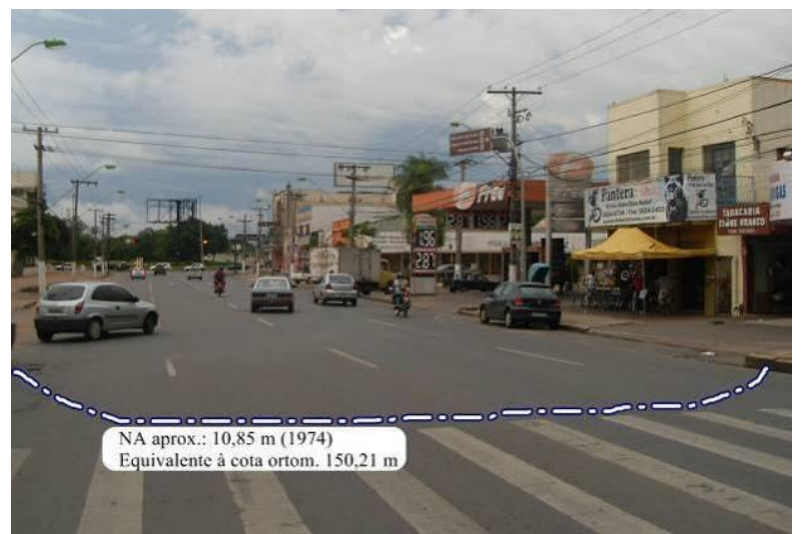

Figura 76 - Cota ortométrica correspondente ao do NA máximo em 1974 na Av. 15 de Novembro (2011) Fonte: Jandira M. Pedrollo

Essa região, no bairro do Porto, em especial a avenida 15 de Novembro, possui grande atividade comercial, além de ser o principal eixo viário à cidade vizinha, Várzea Grande, a segunda maior do estado. É notório o prejuízo causado à população com a ocorrência de cheia 
em proporções semelhantes, haja vista a extensão da área ocupada pelas águas e a importância da região para a cidade. Para demais esclarecimentos, o rio Cuiabá está em sentido perpendicular à avenida, e sua mata ciliar tem início no fundo da imagem mais recente.

A comunidade mais atingida em Cuiabá com a enchente de março de 1974 foi a do bairro do Terceiro, localizado na regional leste da cidade. Apesar de na época boa parte da área estar ociosa, o bairro era ocupado por muitas edificações em sua maioria residenciais de baixa renda. A imagem aérea da Figura 77 ilustra essa região, com o rio Cuiabá ao fundo e em destaque elipsoidal uma área alagada até então sem habitações, a qual veio a se tornar posteriormente a ocupação São Mateus.

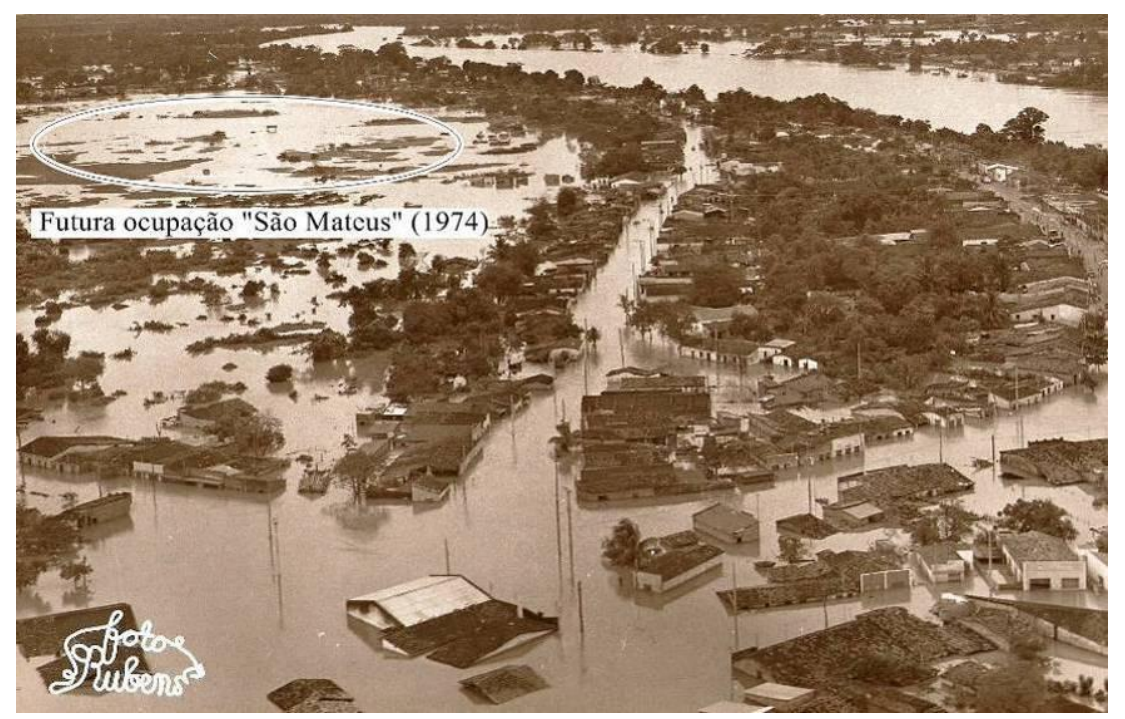

Figura 77 - Inundação no bairro do Terceiro. Destaque: futura ocupação São Mateus (1974)

Fonte: Acervo particular de João C. C. Cardoso

Todas as construções existentes foram demolidas pelo governo federal após a cheia de 1974, assim, houve o remanejamento da população do bairro inteiro. Após essa ocorrência, em virtude dos possíveis riscos à população, a reocupação da área para fins de atividades de uso prolongado, como o residencial, foi proibida.

A Figura 78 ilustra essa mesma localidade do bairro do Terceiro, com o rio Cuiabá à direita e o destaque para o já estabelecido São Mateus, que passou a existir de maneira irregular a partir do início da década de 1980. 


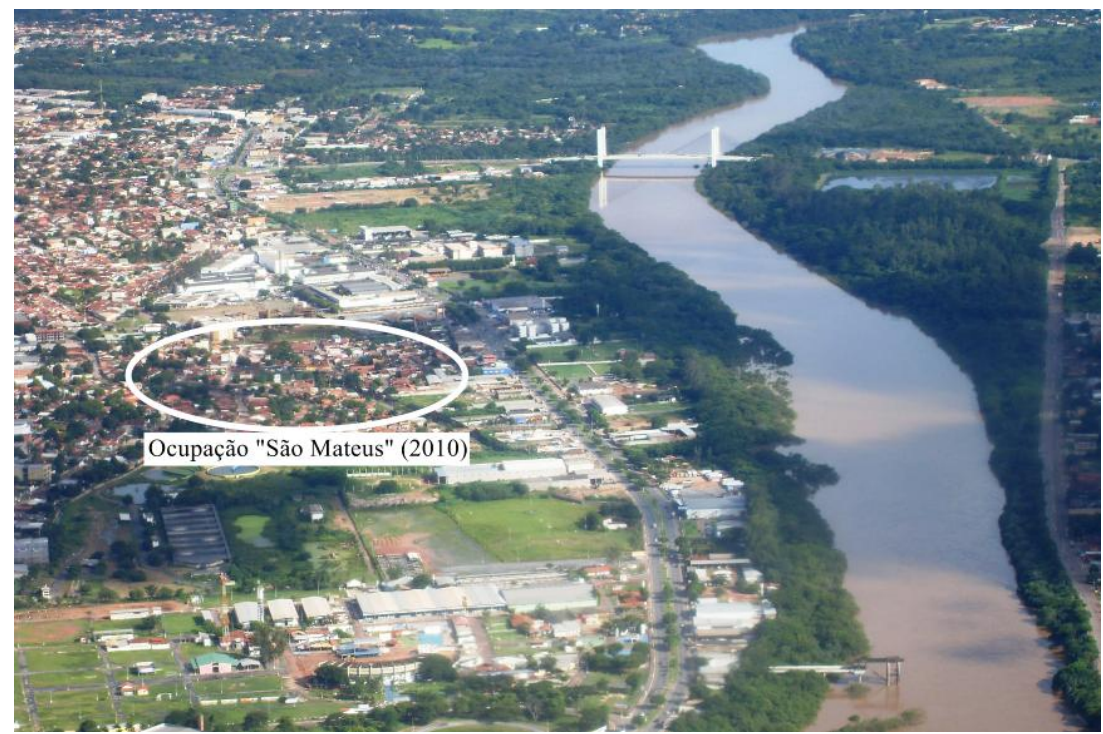

Figura 78 - Regional leste de Cuiabá. Destaque: ocupação São Mateus (2010) Fonte: Rafael P. de Paes

Por um lado as residências alagadas em 1974 foram removidas em prol da segurança dos moradores - atualmente nessa área há uma estação de tratamento de esgotos, um parque de exposições, um ginásio poliesportivo e o shopping popular dos camelôs, logo, de menor risco em caso de intensa enchente. Por outro lado, contudo, a região vizinha passou a ser habitada alguns anos depois, com anuência governamental, e, conforme comprovado em registro fotográfico, na mesma localidade inundada pelas águas do rio Cuiabá.

Segundo informações de Cuiabá (2007b), no ano 2007 existiam no bairro 510 domicílios, com população estimada em 2.110 residentes, em sua maioria de baixa renda. Com uma enchente de proporções semelhantes à de 1974, não só este bairro como outras localidades adjacentes ficariam submersas. É pertinente lembrar que, de acordo com os cálculos hidrodinâmicos deste trabalho, tal situação se repete em períodos de retorno próximos de 100 anos, considerando que a vazão da bacia incremental seja $6.881,7 \mathrm{~L} . \mathrm{s}^{-1} \mathrm{~km}^{-1}$ - ou seja, apenas $23 \%$ maior que a de fevereiro de 1995, e provavelmente menor que a proporcional a 100 anos de recorrência - e que as condições para o amortecimento do APM Manso sejam perfeitas.

Com foco na preparação para o Plano Diretor de Desenvolvimento Urbano de Cuiabá (concluído em 1992) e na necessidade de maior conhecimento do território municipal para seu desdobramento na lei de uso e ocupação do solo, foi realizada uma parceria entre a PMC e a UFMT para a elaboração da Carta Geotécnica de Cuiabá (1990). Este documento foi assumido pelo Plano Diretor de Desenvolvimento Estratégico de Cuiabá (CUIABÁ, 2007a) como um dos instrumentos do processo de planejamento municipal para a implementação da 
Política de Desenvolvimento Estratégico. A Carta traz diversas recomendações quanto ao uso do solo, a qual classificou como planície de inundação os terrenos da zona urbana abaixo da cota ortométrica $150 \mathrm{~m}$. As sugestões apontadas para essa área são:

- $\quad$ Evitar usos de maior permanência humana e de bens perecíveis;

- Implantar sistema de previsão de enchentes;

- $\quad$ Elaborar carta de risco à inundação na escala 1:2.000;

- $\quad$ Adotar plano de defesa civil preventiva;

- $\quad$ Recuperar áreas degradadas em função dos usos pretendidos;

- Implantar sistema viário com pavimentos e drenagem adequados;

- Implantar obrigatoriamente rede coletora de esgotos nas áreas ocupadas;

- $\quad$ Prever rebaixamento do nível d'água e escoamento das paredes em escavação;

- Na implantação de sistemas de adução de águas de abastecimento e coleta de águas pluviais e servidas, utilizar materiais e técnicas apropriadas frente aos possíveis recalques diferenciais;

- $\quad \mathrm{Na}$ implantação de obras, executar investigações geotécnicas específicas visando caracterizar o comportamento dos solos moles;

- As planícies de inundação são áreas apropriadas às atividades de lazer, à preservação da fauna e flora (com a construção de hortos e parques), para a cultura temporária e piscicultura.

A Carta Geotécnica de Cuiabá readvertiu que as planícies de inundação não poderiam ser ocupadas por atividades de permanência prolongada, como habitação. Entre outros trabalhos, foi elaborado um mapa da planície de inundação para a zona urbana, onde são apontadas as regiões abaixo da cota ortométrica $150 \mathrm{~m}$ e os bairros nessa situação.

Ciente de que algumas localidades de Cuiabá situadas em cota inferior à da inundação são habitadas, a atitude mais plausível era evitar que novas habitações fossem firmadas em situações de risco e acatar as medidas apontadas pela Carta para mitigar os possíveis impactos nas comunidades ali instaladas. Apesar da informação sobre as principais áreas de inundação habitadas em Cuiabá, essas regiões continuaram sendo ocupadas. Pior que isso, algumas 
delas, em que já se possuía bastante conhecimento quanto ao risco que corriam, foram incentivadas para construção de moradias com aval e financiamento públicos.

Uma das áreas apontadas pela Carta Geotécnica de Cuiabá como situada na planície de inundação é o bairro Praerinho. À época da cheia de 1995, o bairro continha terrenos com construções prioritariamente residenciais de baixa renda, como ainda é hoje, e outras regiões eram cobertas por vegetação nativa. Ambas as áreas ficaram submersas pela cheia daquele ano, ainda que o rio Cuiabá tenha atingido a cota ortométrica $149,72 \mathrm{~m}$, portanto, inferior à referência dos 150 m. A Figura 79, de fevereiro de 1995, ilustra a inundação do bairro mencionado, com destaque para a parte do terreno até então desocupada, mas que a partir de 2007 foi destinada à construção de um residencial para assentamento de população em área de risco, mesmo que a localidade fique evidentemente comprometida em caso de cheias proporcionais às de 1995 e 1974. A Figura 80 consta de uma imagem de satélite, capturada em 2009, onde é observada a execução das obras desse residencial, inaugurado em 2011.

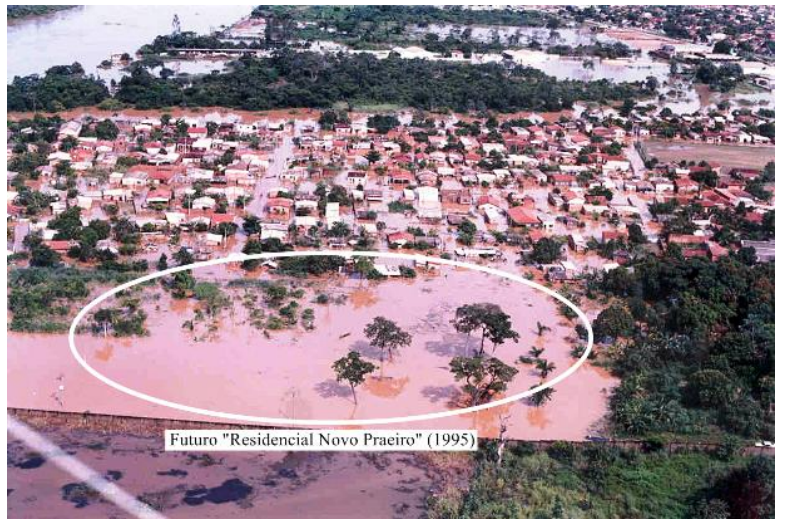

Figura 79 - Inundação no bairro Praerinho.

Destaque: futuro residencial (1995)

Fonte: Acervo IPDU, foto de José Afonso Bottura

Portocarrero

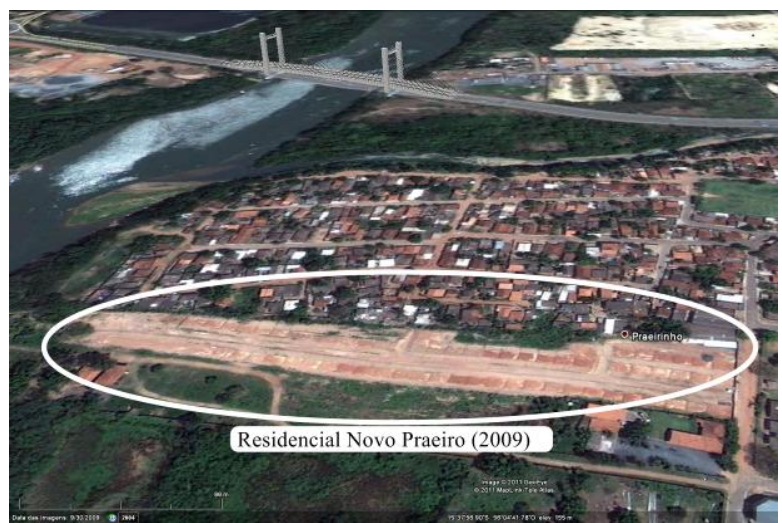

Figura 80 - Bairro Praerinho. Destaque: construção do residencial (2009)

Fonte: Google Earth 6.0.0.1735 (beta)

Historicamente, o bairro Praerinho é um dos mais prejudicados pela elevação das águas do rio Cuiabá na capital mato-grossense, seja por estar instalado em área de preservação permanente ou por ocupar a planície de inundação. O bairro surgiu em meados da década de 1970, e desde então está sob constantes riscos mesmo em cheias de pequenas magnitudes. Segundo informações de Cuiabá (2007b), em 2007 habitavam no bairro aproximadamente 2.100 pessoas em 492 domicílios.

Entre os diversos pretextos utilizados para a construção do residencial são alegados: (i) a necessidade de remoção da população que mora em região de alto risco, como os próprios 
residentes do bairro Praerinho em localidades mais críticas; (ii) a segurança que o reservatório de Manso proporciona ao amortecer as cheias que poderiam impactar a cidade, baseado no maior registro observado em Cuiabá no período de, até então, oito anos e meio; e (iii) a informação de que, com aterramento, o novo residencial estaria locado em cota superior a diversos estabelecimentos importantes de Cuiabá, entre eles o bairro Praerinho $(0,26 \mathrm{~m}$ acima), bairro este que estaria em local seguro, já que sua construção foi aprovada pelo Conselho Municipal de Desenvolvimento Estratégicos da PMC. Como se observa, a certificação de segurança do bairro Praerinho parece ser a aprovação pelo Conselho Municipal, independente da possibilidade de inundação na região.

A respeito da segurança proporcionada pelo APM Manso, o presente trabalho constatou que ela existe efetivamente para cheias com tempo de recorrência entre 50 e 100 anos nas melhores condições possíveis de amortecimento, considerando que o bairro está instalado entre as altitudes ortométricas 148 e $150 \mathrm{~m}$.

Conforme discutido em tópico anterior, as medidas para mitigação dos impactos provocados pelas cheias abordam tanto as medidas estruturais, como a construção de reservatórios para o amortecimento, quanto as não-estruturais, relativos, entre outros, às ações de demarcação de áreas de risco para a ocupação restrita e definitivamente não residencial. Se por um lado o APM Manso foi construído com uma das finalidades principais de mitigação das cheias, configurando em uma medida estrutural, por outro lado, algumas ações nãoestruturais parecem não ser alvo de preocupação. Se o são, já que houve a demarcação das áreas de risco em 1990, e talvez ela esteja desatualizada, a sua importância não foi admitida por inteiro.

Além do problema de inundações pelo rio Cuiabá, diversas localidades têm assistido a transbordamentos de córregos urbanos afluentes daquele rio, em especial na capital do estado. Muitas vezes essas ocorrências são resultado do efeito de remanso do rio principal sobre os tributários ao ter seu nível de água elevado. Uma das referências para a segurança das populações dos municípios banhados pelo rio Cuiabá, mencionado durante todo o trabalho, são as cotas de alerta, emergência e calamidade, estabelecidas pela SUDEC/MT. Apesar delas, nos últimos anos têm sido registradas situações em que o rio Cuiabá atinge níveis de água inferiores à cota alerta e mesmo assim algumas comunidades ficam em vigília independente da Defesa Civil declarar o alerta, mesmo porque algumas vezes as águas invadem essas regiões. Isso é notado tanto nas comunidades instaladas próximo ao rio Cuiabá 
quanto nas situadas perto dos córregos urbanos afluentes. O agravamento tem crescido à medida que as áreas de preservação permanente (APP's) são ocupadas pelas populações que habitam a calha maior dos corpos hídricos, e são atingidas com a elevação do nível de água. Um exemplo a ser citado é a respeito da cheia do rio Cuiabá em 2010, que, na capital do estado atingiu o nível de água máximo de 8,02 m. Nessa ocasião, a SUDEC/MT não decretou o alerta, embora a população ribeirinha já estivesse nesse estado, justificado pelo fato de algumas residências terem sido atingidas pela água.

A antecipação popular à Defesa Civil estadual no estabelecimento do estado de alerta, significa insegurança quanto à definição das cotas. Esse episódio sugere a desatualização do valor da cota de alerta do rio Cuiabá, mesmo que por razões indiretas, já que a questão é do refluxo do rio principal nos seus afluentes e, claro, a ocupação irregular das APP's dos rios e córregos.

Não muito diferente da maioria das cidades em desenvolvimento, Cuiabá tem passado por uma pressão para a ocupação das áreas não propriamente recomendadas para urbanização, ou mesmo não permitidas. Entre os terrenos mais visados estão as APP's e as áreas de planície, que são o amortecimento natural dos corpos hídricos. Quando maiores que a extensão da área de preservação permanente, normalmente as áreas de planície de inundação não são proibidas de serem ocupadas, e muitas delas podem ser aterradas até que se atinja altitude mínima para segurança. O problema é que quando o rio costuma utilizar a planície durante as cheias, essa medida compromete a qualidade de vida especialmente das comunidades a jusante, independente da sua renda.

Uma interessante medida não-estrutural, voltada ao conhecimento das grandezas de cada enchente e à possibilidade de inundação em uma bacia hidrográfica, é um sistema de alerta eficaz, que comporia um sistema de suporte de decisões (SSD) voltado às cheias. A este respeito, Barros (2004) explica que um SSD é um conjunto de ferramentas com o objetivo de auxiliar seus usuários na obtenção de informações e na identificação de alternativas relevantes para a escolha de uma solução em problemas de decisão. $\mathrm{O}$ autor acrescenta que a função dos modelos de suporte à decisão não é a de apontar respostas, mas sim a de permitir que decisões sejam tomadas com maior segurança.

O único sistema de alerta de inundação na BHC acontece por meio de acompanhamento linimétrico nas principais localidades do percurso do rio Cuiabá, até a confluência com o rio Paraguai, no Pantanal, por onde seguem os monitoramentos para previsão de níveis de água em algumas estações fluviométricas, conforme BRASIL (2010c). 
A esse problema, é somado o fato de que não é conhecido sequer o tempo exato da propagação da onda de cheia entre as principais estações fluviométricas. Nos métodos do sistema da BHC não há ferramentas com suporte informatizado, o que poderia oferecer ampliação das oportunidades de aplicação, onde seriam inclusos, por exemplo, ferramentas de SIG, além da melhor eficiência admitida por modelagens hidráulicas e hidrológicas. Por essas razões, e porque a importância do conhecimento sobre a bacia tem aumentado, especialmente em função do crescimento urbano que a região metropolitana do Vale do rio Cuiabá tem assistido, se faz necessário expandir as pesquisas relacionadas à bacia hidrográfica do rio Cuiabá e da região hidrográfica do Alto Paraguai como um todo. Nessa conjuntura, é fundamental a expansão da rede de estações fluviométricas e meteorológicas em termos quantitativos e qualitativos. Assim, entre outros, não seria necessário a discretização horária gerada a partir de dados observados diariamente, o que certamente prejudica a qualidade de uma pesquisa de abordagem hidráulico-hidrológica.

O aprimoramento das informações sobre a topografia da bacia do rio Cuiabá permitiria a elaboração de mapas de manchas de inundação com maior precisão que da maneira como é encontrada atualmente, cuja disponibilidade gratuita se dá com curvas de nível a cada 100 metros. Outrossim, é importante melhorar as informações acerca das seções topobatimétricas dos rios da bacia, bem como a atualização frequente das curvas-chave, pois tendem a se modificar nos corpos hídricos de fundo móvel, caso muito comum na região pantaneira, especialmente por ser local de depósito de sedimentos não-consolidados.

A qualidade das informações que alimentam estudos voltados ao funcionamento do sistema hídrico é essencial para o conhecimento da BHC e só melhoram as certezas a respeito dos limites dessa bacia e dos seus possíveis prejuízos. Em todo caso, o que se sabe por antecipação é que esses limites são naturalmente alcançáveis. Disso, conclui-se que compete à sociedade a organização para reduzi-los o máximo possível em frequência e intensidade. Para tanto, é importante evitar o errôneo pensamento que ações isoladas, como a construção de um reservatório, são suficientes para conter as inundações. Conforme já mencionado, para mitigar os efeitos das inundações, além dos meios estruturais, sempre devem ser lembradas as ações relativas ao planejamento e à ocupação do solo. 
APÊNDICE B - Estações fluviométricas e seções topobatimétricas nos rios Cuiabá e Manso

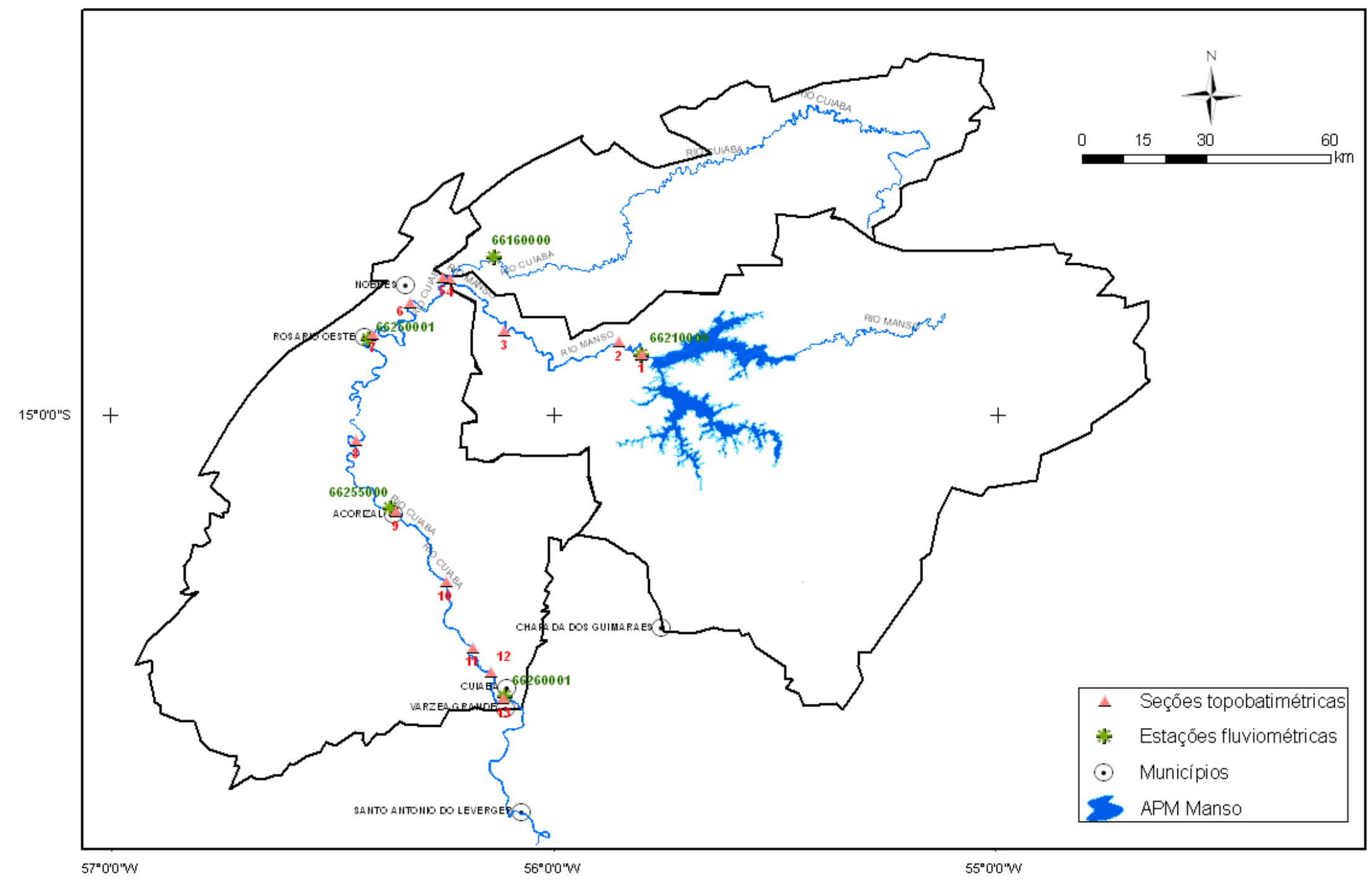


APÊNDICE C - Seções topobatimétricas dos rios Cuiabá e Manso

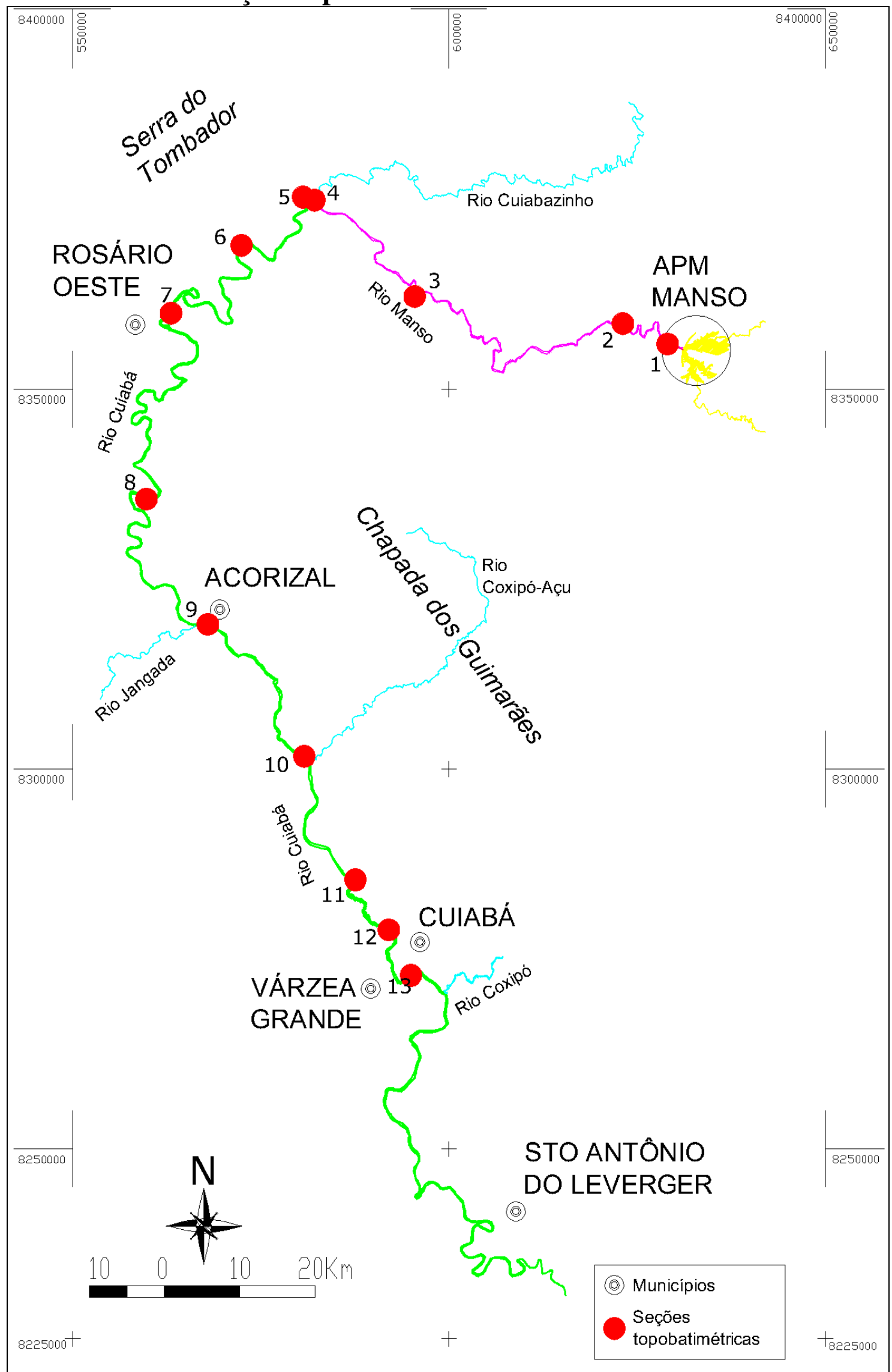



ANEXOS 


\section{ANEXO A - Características principais da UHE Manso}

UHE Manso

Região hidrográfica do Alto Paraguai;

Bacia hidrográfica do rio Cuiabá;

Sub-bacia hidrográfica do rio Manso;

Município: Chapada dos Guimarães;

Operadora: Eletrobrás Furnas;

Potência nominal: 212MW.

\section{Reservatório}

NA mínimo normal de operação: 278,00;

NA máximo normal de operação: 287,00;

NA máximo maximorum: 289,80 m;

NA volume de espera: 287,00 a 288,15 m;

Área inundada: (cota 289,80 m.): 427 km²;

Área inundada (cota 287,00 m): $387 \mathrm{~km}^{2}$

Volume máx. normal (cota 287m): 7,337 x $10^{9} \mathrm{~m}^{3}$;

Volume útil (cotas 278 a $287 \mathrm{~m}$ ): $2,951 \times 10^{9} \mathrm{~m}^{3}$;

Volume de espera: $0,455 \times 10^{9} \mathrm{~m}^{3}$;

Tempo de retorno máximo relativo ao volume de espera: 20 anos.

\section{Rio Manso}

Área da sub-bacia do Manso: $9.365 \mathrm{~km}^{2}$

Vazão média de longo termo: $170 \mathrm{~m}^{3} / \mathrm{s}$;

Vazão regularizada: $135 \mathrm{~m}^{3} / \mathrm{s}$;

Vazão ( $\operatorname{Tr}=50$ anos): $2.206 \mathrm{~m}^{3} / \mathrm{s}$;

Vazão $\left(\operatorname{Tr}=10 \mathrm{mil}\right.$ anos): $5.106 \mathrm{~m}^{3} / \mathrm{s}$;

Foz: rio Cuiabá (aprox. 80 km a jusante da UHE).

Níveis de água de jusante

NA máximo maximorum: 234,05 m;

NA máximo normal: 225,84 m;

NA mínimo normal: 224,23 m;

\section{Tomada de água}

Tipo: gravidade;

Comprimento: 45,00 m;

$\mathrm{N}^{\mathrm{o}}$ de condutos: 4 ;

Cota da soleira: 264,90 m;

Diâmetro interno: $5.200 \mathrm{~mm}$.

\section{Vertedouro principal}

Tipo: gravidade;

$\mathrm{N}^{\mathrm{o}}$ de vãos: 3 ;

Cota da crista da ogiva (soleira vertente): 276,25 m;

Comprimento total: $50,00 \mathrm{~m}$;

Comportas:

Tipo: Segmento;

$\mathrm{N}^{\mathrm{o}}$ de unidades: 3 ;

Dimensões: 9,5 x 13,5 m;

Vazão efluente máx: $2.990 \mathrm{~m}^{3} / \mathrm{s}$.

\section{Vertedouro auxiliar}

Tipo: gravidade, sem controle hidráulico;

$\mathrm{N}^{\mathrm{o}}$ unidades: 2;

Cota da soleira: $289,25 \mathrm{~m}$;

Foz: Ribeirão Arraia, afluente da margem direita do rio Manso, cuja foz está a $7 \mathrm{~km}$ a jusante da barragem.

\section{Turbinas}

$\mathrm{N}^{\mathrm{o}}$ de unidades: 4;

Tipo: Francis de eixo vertical;

Potência Nominal: 52,5 MW;

Potência máxima: $60 \mathrm{MW}$;

Rotação: 180 rpm;

Engolimento (queda nominal): 104,6 m³/s;

Queda líquida nominal: 57,5 m.

\section{Barragem}

NA coroamento: $291,50 \mathrm{~m}$;

Comprimento total: $3.680 \mathrm{~m}$;

Em concreto: 140 m;

Em solo compactado: $3.120 \mathrm{~m}$;

Em enroncamento: $420 \mathrm{~m}$.

\section{Diques}

No unidades: 7;

Comprimento total: $3.855 \mathrm{~m}$. 


\section{Estruturas de terra e enroncamento}

Unidades: Barragem da margem direita + barragem da margem esquerda, barragem do leito do rio e diques;

Comprimento (m): $1180+2015+369+3855$;

Volume $\left(\mathrm{hm}^{3}\right): 1,27+1,40+1,73+0,34$.

\section{Casa de força}

Dimensão: 116,80 m 16,80 m;

$\mathrm{N}^{\mathrm{o}}$ de unidades: 4 ;

Ponte rolante: 2 x 650/150 kN.

\section{Subestação}

Tipo: Seccionadora;

Área total: 118 x 105m;

Tensão nominal: $230 \mathrm{kV}$;

Esquema: barramento duplo, 1 disjuntor e 4 chaves seccionadoras por vão.

\section{Geradores}

$\mathrm{N}^{\mathrm{o}}$ de unidades: 4 ;

Tipo: Síncrono, de eixo vertical;

Potência nominal aparente: 55,5 MVA;

Potência máxima contínua: 62,5 MVA;

Tensão nominal: $13,8 \mathrm{kV}+/-5 \%$;

Fator de potência: 0,95;

Frequiência: $60 \mathrm{~Hz}$;

Energia firme: 92,0 MW/ano.

\section{Transformadores elevadores}

$\mathrm{N}^{\mathrm{o}}$ de unidades: $4+1$ (reserva);

Tipo: Monofásico;

Potência máxima contínua: 62,5 MVA;

Capacidade total em operação: 250 MVA;

Tensão primária: 13,8 kV;

Tensão secundária: $230 \mathrm{kV}$;

Fabricante: Toshiba. 


\section{ANEXO B - Topobatimetria nos rios Manso (ST 1 a ST 4) e Cuiabá (ST 5 a ST 16)}

Nota:

$\mathrm{RN}$ - Referencial de nível

PI - Ponto inicial

PT - Pontos topométricos

NA - Nível de água

ME - Margem esquerda

MD - Margem direita

$\mathrm{PF}$ - Ponto final 
ST 1 - Jusante ponte UHE Manso

\begin{tabular}{|c|c|c|}
\hline Referencial & $\begin{array}{l}\text { Distância } \\
\text { transversal (m) }\end{array}$ & $\begin{array}{l}\text { Cota } \\
\text { Ortom. (m) }\end{array}$ \\
\hline $\mathrm{RN}=\mathrm{PI}$ & 0,00 & 232,068 \\
\hline РT01 & 12,20 & 229,184 \\
\hline PT02 & 18,40 & 226,334 \\
\hline NA-ME & 20,90 & 225,079 \\
\hline 1 & 22,90 & 223,779 \\
\hline 2 & 24,90 & 222,799 \\
\hline 3 & 29,90 & 220,949 \\
\hline 4 & 34,90 & 221,079 \\
\hline 5 & 39,90 & 221,459 \\
\hline 6 & 44,90 & 221,169 \\
\hline 7 & 49,90 & 220,899 \\
\hline 8 & 54,90 & 220,849 \\
\hline 9 & 59,90 & 220,539 \\
\hline 10 & 64,90 & 220,629 \\
\hline 11 & 69,90 & 220,679 \\
\hline 12 & 74,90 & 220,709 \\
\hline 13 & 79,90 & 220,599 \\
\hline 14 & 84,90 & 220,509 \\
\hline 15 & 89,90 & 220,429 \\
\hline 16 & 94,90 & 220,549 \\
\hline 17 & 99,90 & 220,999 \\
\hline 18 & 104,90 & 222,179 \\
\hline 19 & 109,90 & 222,559 \\
\hline 20 & 114,90 & 223,729 \\
\hline NA-MD & 117,40 & 225,079 \\
\hline PT03 & 121,00 & 228,152 \\
\hline PF-MD & 126,70 & 229,873 \\
\hline
\end{tabular}

ST 2 - Faz. Raizama

\begin{tabular}{|c|c|c|}
\hline Referencial & $\begin{array}{l}\text { Distância } \\
\text { transversal (m) }\end{array}$ & $\begin{array}{l}\text { Cota } \\
\text { Ortom. (m) }\end{array}$ \\
\hline PI-ME & 0,00 & 230,028 \\
\hline PT01 & 8,60 & 226,313 \\
\hline NA-ME & 14,90 & 220,378 \\
\hline 1 & 16,90 & 219,218 \\
\hline 2 & 21,90 & 217,788 \\
\hline 3 & 26,90 & 217,638 \\
\hline 4 & 31,90 & 217,418 \\
\hline 5 & 36,90 & 216,998 \\
\hline 6 & 41,90 & 216,638 \\
\hline 7 & 46,90 & 216,638 \\
\hline 8 & 51,90 & 216,928 \\
\hline 9 & 56,90 & 215,978 \\
\hline 10 & 61,90 & 216,008 \\
\hline 11 & 66,90 & 215,858 \\
\hline 12 & 71,90 & 215,988 \\
\hline 13 & 76,90 & 216,338 \\
\hline 14 & 81,90 & 216,268 \\
\hline 15 & 86,90 & 216,308 \\
\hline 16 & 91,90 & 216,838 \\
\hline 17 & 96,90 & 216,988 \\
\hline 18 & 101,90 & 217,498 \\
\hline 19 & 106,90 & 218,338 \\
\hline NA-MD & 108,90 & 220,378 \\
\hline РT02 & 124,90 & 221,408 \\
\hline PT03 & 141,20 & 224,185 \\
\hline РT04 & 145,40 & 225,311 \\
\hline $\mathrm{RN}=\mathrm{PF}$ & 146,00 & 228,728 \\
\hline
\end{tabular}

ST 1 - Jusante ponte UHE Manso

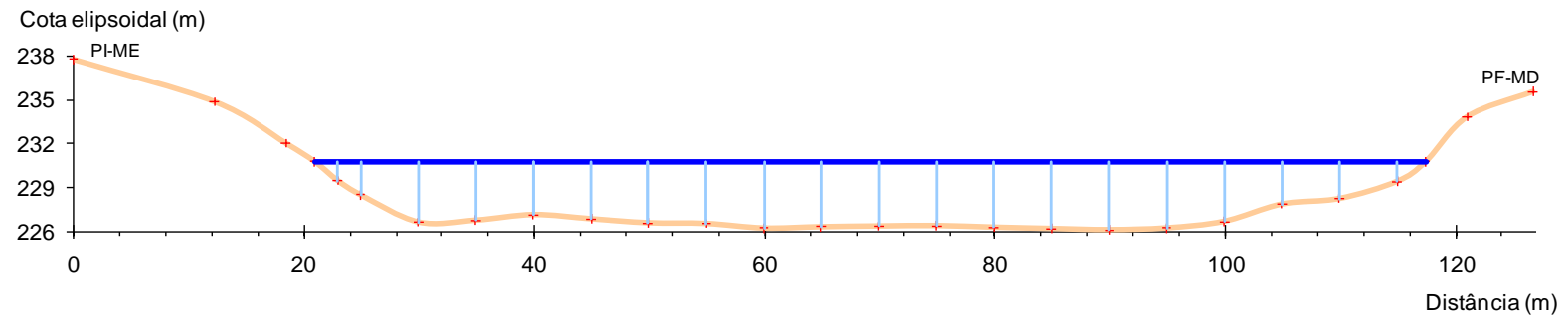

ST 2 - Faz. Raizama

Cota elipsoidal (m)

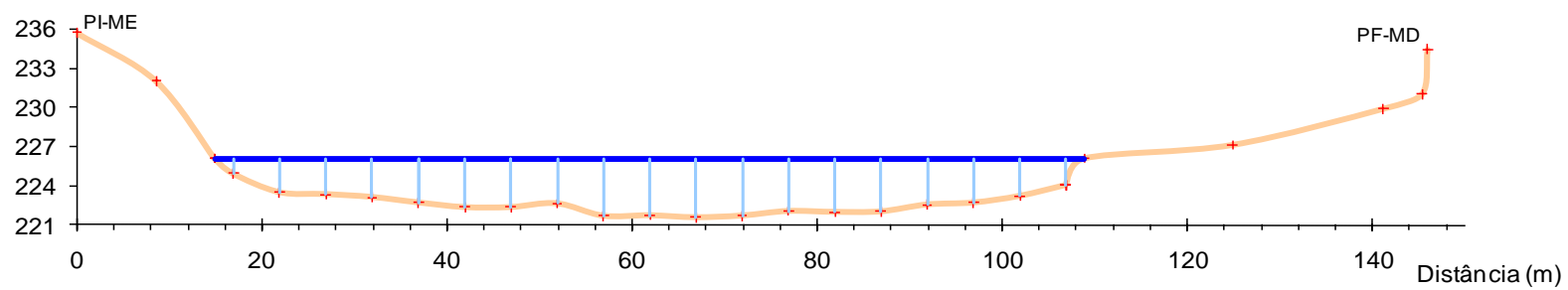


ST 3 - Ponte de madeira

\begin{tabular}{|c|c|c|}
\hline Referencial & $\begin{array}{l}\text { Distância } \\
\text { transversal (m) }\end{array}$ & $\begin{array}{l}\text { Cota } \\
\text { Ortom. (m) }\end{array}$ \\
\hline PI-ME & 0,00 & 202,175 \\
\hline PT01 & 10,45 & 201,403 \\
\hline NA-ME & 12,10 & 198,203 \\
\hline 1 & 15,10 & 196,683 \\
\hline 2 & 18,10 & 196,243 \\
\hline 3 & 22,10 & 196,363 \\
\hline 4 & 27,10 & 195,883 \\
\hline 5 & 32,10 & 195,733 \\
\hline 6 & 37,10 & 195,753 \\
\hline 7 & 42,10 & 195,963 \\
\hline 8 & 47,10 & 196,643 \\
\hline 9 & 52,10 & 196,013 \\
\hline 10 & 57,10 & 196,573 \\
\hline 11 & 62,10 & 196,423 \\
\hline 12 & 67,10 & 196,363 \\
\hline 13 & 72,10 & 195,733 \\
\hline 14 & 77,10 & 193,623 \\
\hline 15 & 82,10 & 194,283 \\
\hline 16 & 87,10 & 194,293 \\
\hline 17 & 92,10 & 194,463 \\
\hline 18 & 97,10 & 194,573 \\
\hline 19 & 102,10 & 194,663 \\
\hline 20 & 107,10 & 194,593 \\
\hline 21 & 112,10 & 194,043 \\
\hline 22 & 117,10 & 195,063 \\
\hline 23 & 122,10 & 195,043 \\
\hline 24 & 127,10 & 197,393 \\
\hline NA-MD & 129,50 & 198,203 \\
\hline РT02 & 136,50 & 200,553 \\
\hline $\mathrm{RN}=\mathrm{PF}$ & 141,00 & 202,413 \\
\hline
\end{tabular}

ST 4 - Montante à foz do rio Manso

\begin{tabular}{|c|c|c|}
\hline Referencial & $\begin{array}{l}\text { Distância } \\
\text { transversal (m) }\end{array}$ & $\begin{array}{l}\text { Cota } \\
\text { Ortom. (m) }\end{array}$ \\
\hline PI-ME & 0,00 & 196,555 \\
\hline PT01 & 0,40 & 195,258 \\
\hline РT02 & 5,50 & 195,025 \\
\hline NA-ME & 10,60 & 192,215 \\
\hline 1 & 12,60 & 189,895 \\
\hline 2 & 14,60 & 189,465 \\
\hline 3 & 19,60 & 188,955 \\
\hline 4 & 24,60 & 188,675 \\
\hline 5 & 29,60 & 188,715 \\
\hline 6 & 34,60 & 188,615 \\
\hline 7 & 39,60 & 188,145 \\
\hline 8 & 44,60 & 188,205 \\
\hline 9 & 49,60 & 187,755 \\
\hline 10 & 54,60 & 187,385 \\
\hline 11 & 59,60 & 187,025 \\
\hline 12 & 64,60 & 187,375 \\
\hline 13 & 69,60 & 188,005 \\
\hline 14 & 74,60 & 186,665 \\
\hline 15 & 79,60 & 186,535 \\
\hline 16 & 84,60 & 186,065 \\
\hline 17 & 89,60 & 187,825 \\
\hline 18 & 94,60 & 188,935 \\
\hline 19 & 99,60 & 189,935 \\
\hline NA-MD & 102,60 & 192,215 \\
\hline PT03 & 104,60 & 193,797 \\
\hline $\mathrm{RN}$ & 105,90 & 194,047 \\
\hline PT04 & 108,10 & 194,825 \\
\hline PT05 & 112,10 & 197,892 \\
\hline РT06 & 113,70 & 198,982 \\
\hline PF-MD & 115,10 & 199,505 \\
\hline
\end{tabular}

ST 3 - Ponte de madeira

Cota elipsoidal $(\mathrm{m})$

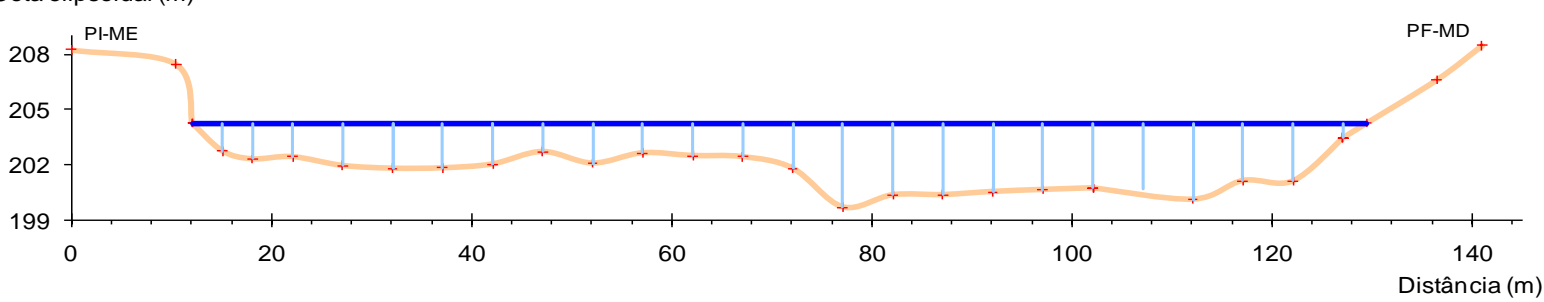

ST 4 - Montante à foz do rio Manso

Cota elipsoidal $(\mathrm{m})$

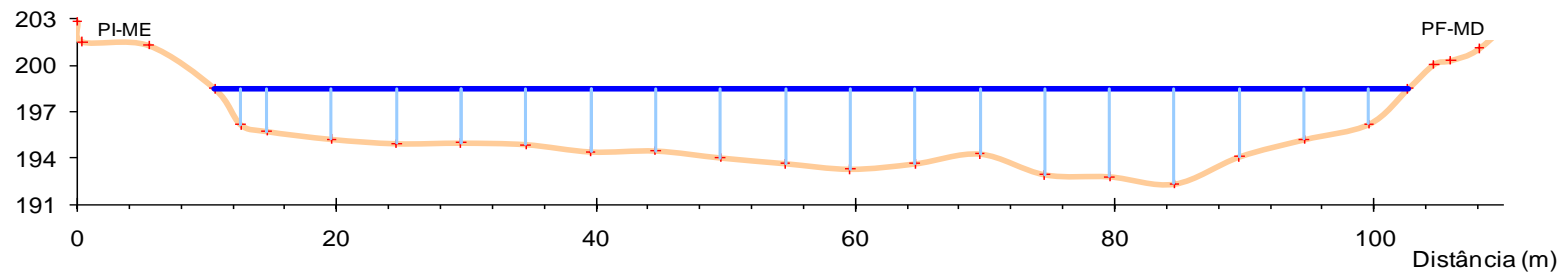


ST 5 - Jusante à foz do rio Manso

\begin{tabular}{|c|c|c|}
\hline Referencial & $\begin{array}{l}\text { Distância } \\
\text { transversal (m) }\end{array}$ & $\begin{array}{l}\text { Cota } \\
\text { Ortom. (m) }\end{array}$ \\
\hline PI-ME & 0,00 & 195,086 \\
\hline РT01 & 1,15 & 193,586 \\
\hline РT02 & 6,10 & 193,386 \\
\hline NA-ME & 8,80 & 191,556 \\
\hline 1 & 10,80 & 190,256 \\
\hline 2 & 15,80 & 189,536 \\
\hline 3 & 20,80 & 188,676 \\
\hline 4 & 25,80 & 188,696 \\
\hline 5 & 30,80 & 188,736 \\
\hline 6 & 35,80 & 188,826 \\
\hline 7 & 40,80 & 188,696 \\
\hline 8 & 45,80 & 188,716 \\
\hline 9 & 50,80 & 188,656 \\
\hline 10 & 55,80 & 188,606 \\
\hline 11 & 60,80 & 188,666 \\
\hline 12 & 65,80 & 188,746 \\
\hline 13 & 70,80 & 188,746 \\
\hline 14 & 75,80 & 188,456 \\
\hline 15 & 80,80 & 188,376 \\
\hline 16 & 85,80 & 187,996 \\
\hline 17 & 90,80 & 187,956 \\
\hline 18 & 95,80 & 187,436 \\
\hline 19 & 100,80 & 187,056 \\
\hline 20 & 105,80 & 186,456 \\
\hline 21 & 110,80 & 186,056 \\
\hline 22 & 115,80 & 184,996 \\
\hline 23 & 120,80 & 185,096 \\
\hline 24 & 125,80 & 185,766 \\
\hline 25 & 130,80 & 186,046 \\
\hline 26 & 135,80 & 190,006 \\
\hline NA-MD & 138,80 & 191,556 \\
\hline PT03 & 145,10 & 195,145 \\
\hline $\mathrm{RN}=\mathrm{PF}$ & 151,50 & 198,256 \\
\hline
\end{tabular}

ST 5 - Jusante à foz do rio Manso
ST 6 - Pesqueiro Coqueiro

\begin{tabular}{|c|c|c|}
\hline Referencial & $\begin{array}{l}\text { Distância } \\
\text { transversal (m) }\end{array}$ & $\begin{array}{l}\text { Cota } \\
\text { Ortom. (m) }\end{array}$ \\
\hline PI-ME & 0,00 & 191,725 \\
\hline PT01 & 2,70 & 190,334 \\
\hline РT02 & 3,70 & 189,483 \\
\hline PT03 & 9,80 & 188,163 \\
\hline NA-ME & 11,80 & 187,062 \\
\hline 1 & 13,80 & 184,762 \\
\hline 2 & 16,80 & 184,362 \\
\hline 3 & 21,80 & 184,242 \\
\hline 4 & 26,80 & 183,842 \\
\hline 5 & 31,80 & 183,692 \\
\hline 6 & 36,80 & 183,642 \\
\hline 7 & 41,80 & 183,592 \\
\hline 8 & 46,80 & 183,722 \\
\hline 9 & 51,80 & 183,982 \\
\hline 10 & 56,80 & 183,412 \\
\hline 11 & 61,80 & 183,342 \\
\hline 12 & 66,80 & 183,422 \\
\hline 13 & 71,80 & 183,552 \\
\hline 14 & 76,80 & 183,442 \\
\hline 15 & 81,80 & 183,252 \\
\hline 16 & 86,80 & 183,322 \\
\hline 17 & 91,80 & 182,752 \\
\hline 18 & 96,80 & 182,942 \\
\hline 19 & 101,80 & 182,792 \\
\hline 20 & 106,80 & 183,082 \\
\hline 21 & 111,80 & 182,932 \\
\hline 22 & 116,80 & 182,802 \\
\hline 23 & 121,80 & 182,762 \\
\hline 24 & 126,80 & 182,782 \\
\hline 25 & 131,80 & 183,962 \\
\hline NA-MD & 133,80 & 187,062 \\
\hline PT04 & 136,30 & 189,04 \\
\hline РT05 & 136,80 & 190,691 \\
\hline РT06 & 143,80 & 191,887 \\
\hline РT07 & 151,80 & 193,038 \\
\hline $\mathrm{RN}=\mathrm{PF}$ & 154,15 & 193,712 \\
\hline
\end{tabular}

Cota elipsoidal (m)

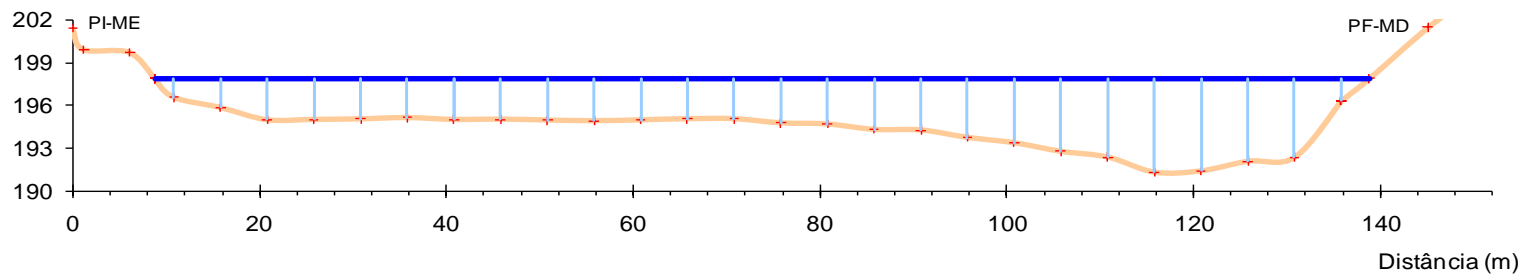

ST 6 - Pesqueiro Coqueiro

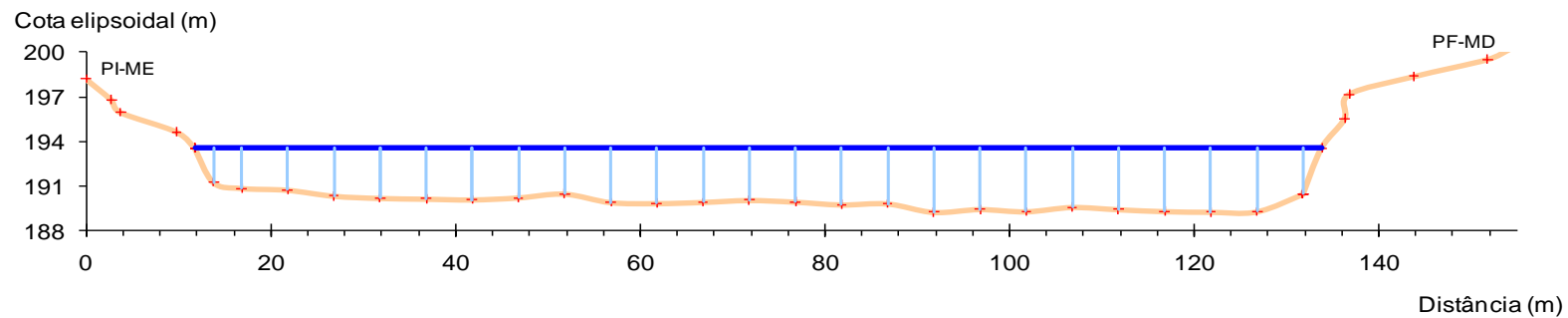


ST 7 - Rosário Oeste

\begin{tabular}{|lll|}
\hline Referencial & $\begin{array}{l}\text { Distância } \\
\text { transversal (m) }\end{array}$ & $\begin{array}{l}\text { Cota } \\
\text { Ortom. }(\mathrm{m})\end{array}$ \\
RN=PI & 0,00 & 189,411 \\
PT01 & 2,00 & 189,234 \\
NA-ME & 8,30 & 187,864 \\
1 & 10,30 & 186,304 \\
2 & 15,30 & 184,624 \\
3 & 20,30 & 184,064 \\
4 & 25,30 & 184,024 \\
5 & 30,30 & 183,994 \\
6 & 35,30 & 183,814 \\
7 & 40,30 & 183,764 \\
8 & 45,30 & 183,644 \\
9 & 50,30 & 183,664 \\
10 & 55,30 & 183,764 \\
11 & 60,30 & 183,704 \\
12 & 65,30 & 183,594 \\
13 & 70,30 & 183,664 \\
14 & 75,30 & 183,714 \\
15 & 80,30 & 183,354 \\
16 & 85,30 & 183,594 \\
17 & 90,30 & 183,664 \\
18 & 95,30 & 183,304 \\
19 & 100,30 & 183,274 \\
20 & 105,30 & 183,464 \\
21 & 110,30 & 183,764 \\
22 & 115,30 & 183,784 \\
23 & 120,30 & 183,814 \\
24 & 125,30 & 183,914 \\
25 & 130,30 & 183,954 \\
26 & 135,30 & 184,534 \\
27 & 140,30 & 186,704 \\
NA-MD & 142,30 & 187,864 \\
PT02 & 144,80 & 189,189 \\
PT03 & 149,20 & 190,134 \\
PF-MD & 164,30 & 192,264 \\
\hline
\end{tabular}

ST 8 - Porto Cachoeirinha

\begin{tabular}{|c|c|c|}
\hline Referencial & $\begin{array}{l}\text { Distância } \\
\text { transversal (m) }\end{array}$ & $\begin{array}{l}\text { Cota } \\
\text { Ortom. (m) }\end{array}$ \\
\hline $\mathrm{RN}=\mathrm{PI}$ & 0,00 & 178,881 \\
\hline РT01 & 20,55 & 176,366 \\
\hline NA-ME & 26,80 & 174,246 \\
\hline 1 & 29,80 & 172,296 \\
\hline 2 & 34,80 & 171,266 \\
\hline 3 & 39,80 & 170,276 \\
\hline 4 & 44,80 & 170,246 \\
\hline 5 & 49,80 & 169,896 \\
\hline 6 & 54,80 & 169,646 \\
\hline 7 & 59,80 & 169,466 \\
\hline 8 & 64,80 & 169,416 \\
\hline 9 & 69,80 & 169,336 \\
\hline 10 & 74,80 & 169,196 \\
\hline 11 & 79,80 & 169,226 \\
\hline 12 & 84,80 & 169,436 \\
\hline 13 & 89,80 & 169,446 \\
\hline 14 & 94,80 & 170,116 \\
\hline 15 & 99,80 & 169,746 \\
\hline 16 & 104,80 & 169,806 \\
\hline 17 & 109,80 & 169,776 \\
\hline 18 & 114,80 & 170,076 \\
\hline 19 & 119,80 & 169,996 \\
\hline 20 & 124,80 & 170,096 \\
\hline 21 & 129,80 & 170,106 \\
\hline 22 & 134,80 & 170,296 \\
\hline 23 & 139,80 & 170,346 \\
\hline 24 & 144,80 & 170,806 \\
\hline 25 & 149,80 & 172,996 \\
\hline NA-MD & 151,80 & 174,246 \\
\hline РT02 & 155,30 & 175,741 \\
\hline PF-MD & 168,80 & 177,846 \\
\hline
\end{tabular}

ST 7 - Rosário Oeste

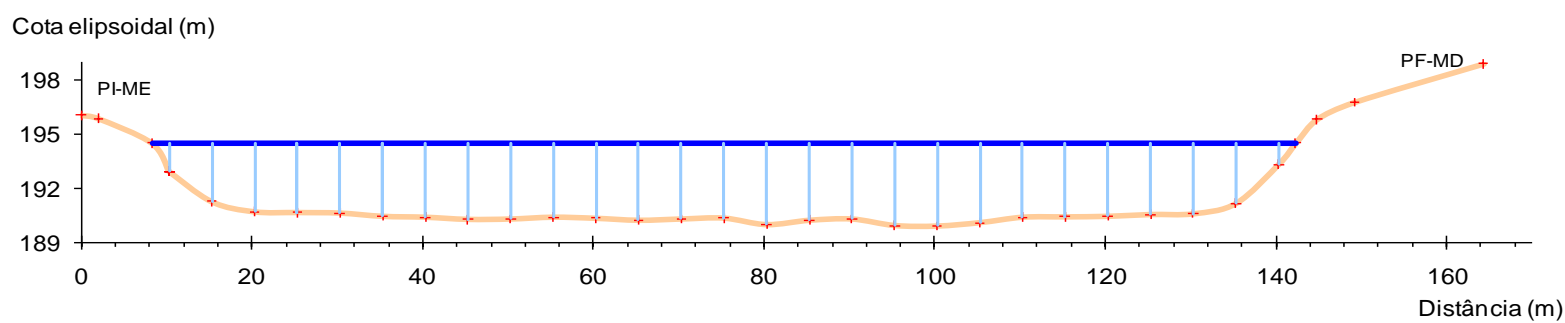

ST 8 - Porto Cachoeirinha

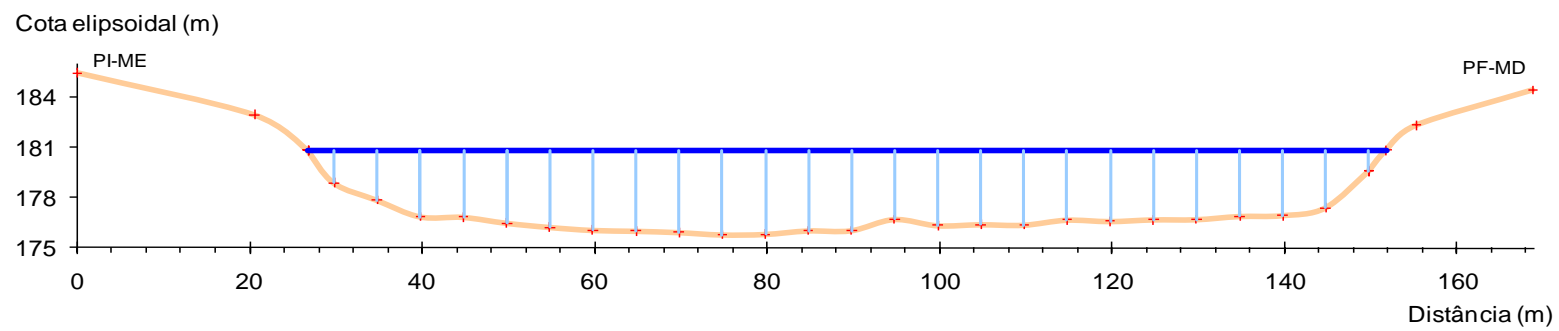


ST 9 - Acorizal

\begin{tabular}{|c|c|c|}
\hline Referencial & $\begin{array}{l}\text { Distância } \\
\text { transversal (m) }\end{array}$ & $\begin{array}{l}\text { Cota } \\
\text { Ortom. (m) }\end{array}$ \\
\hline $\mathrm{RN}=\mathrm{PI}$ & 0,00 & 170,36 \\
\hline PT01 & 13,00 & 169,305 \\
\hline NA-ME & 32,80 & 167,751 \\
\hline 1 & 35,80 & 167,751 \\
\hline 2 & 40,80 & 165,131 \\
\hline 3 & 45,80 & 163,921 \\
\hline 4 & 50,80 & 163,141 \\
\hline 5 & 55,80 & 162,751 \\
\hline 6 & 60,80 & 162,251 \\
\hline 7 & 65,80 & 162,231 \\
\hline 8 & 70,80 & 161,941 \\
\hline 9 & 75,80 & 161,091 \\
\hline 10 & 80,80 & 161,301 \\
\hline 11 & 85,80 & 161,051 \\
\hline 12 & 90,80 & 162,501 \\
\hline 13 & 95,80 & 161,351 \\
\hline 14 & 100,80 & 161,701 \\
\hline 15 & 105,80 & 161,251 \\
\hline 16 & 110,80 & 161,401 \\
\hline 17 & 115,80 & 161,651 \\
\hline 18 & 120,80 & 161,601 \\
\hline 19 & 125,80 & 161,571 \\
\hline 20 & 130,80 & 161,311 \\
\hline 21 & 135,80 & 161,221 \\
\hline 22 & 140,80 & 161,251 \\
\hline 23 & 145,80 & 161,301 \\
\hline 24 & 150,80 & 162,331 \\
\hline 25 & 155,80 & 165,001 \\
\hline 26 & 160,80 & 166,241 \\
\hline NA-MD & 165,00 & 167,751 \\
\hline PT02 & 169,60 & 169,841 \\
\hline PT03 & 176,40 & 170,236 \\
\hline PF-MD & 183,30 & 171,376 \\
\hline
\end{tabular}

ST 9 - Acorizal

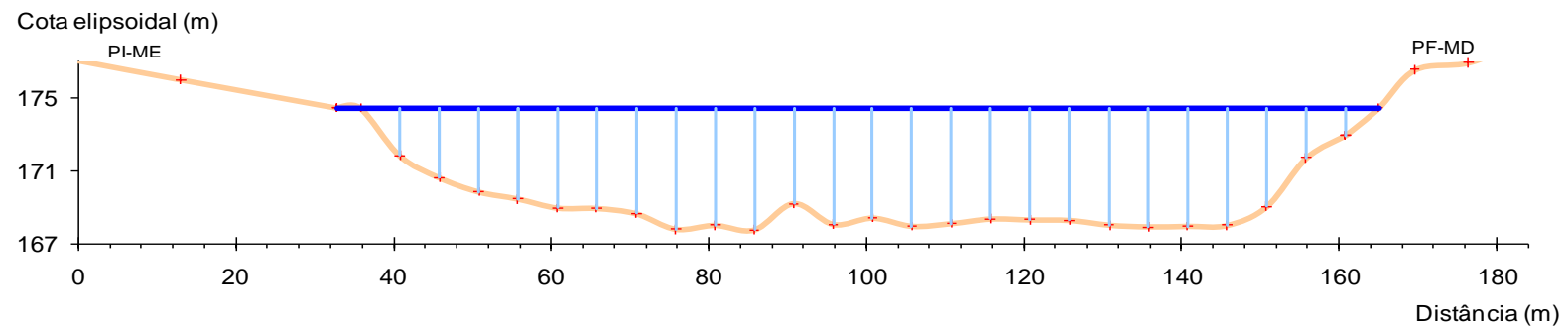


ST 10 - Nossa Sr ${ }^{\mathrm{a}}$ da Guia

\begin{tabular}{|c|c|c|}
\hline Referencial & $\begin{array}{l}\text { Distância } \\
\text { transversal (m) }\end{array}$ & $\begin{array}{l}\text { Cota } \\
\text { Ortom. (m) }\end{array}$ \\
\hline $\mathrm{RN}=\mathrm{PF}$ & 0,00 & 157,391 \\
\hline PT01 & 10,00 & 155,703 \\
\hline РT02 & 18,30 & 153,71 \\
\hline PT03 & 23,58 & 153,025 \\
\hline NA-ME & 25,68 & 151,638 \\
\hline 1 & 28,68 & 148,888 \\
\hline 2 & 33,68 & 148,618 \\
\hline 3 & 38,68 & 147,638 \\
\hline 4 & 43,68 & 147,598 \\
\hline 5 & 48,68 & 147,478 \\
\hline 6 & 53,68 & 147,558 \\
\hline 7 & 58,68 & 147,668 \\
\hline 8 & 63,68 & 147,728 \\
\hline 9 & 68,68 & 147,818 \\
\hline 10 & 73,68 & 147,788 \\
\hline 11 & 78,68 & 147,778 \\
\hline 12 & 83,68 & 147,748 \\
\hline 13 & 88,68 & 147,638 \\
\hline 14 & 93,68 & 147,588 \\
\hline 15 & 98,68 & 147,528 \\
\hline 16 & 103,68 & 147,508 \\
\hline 17 & 108,68 & 147,478 \\
\hline 18 & 113,68 & 147,638 \\
\hline 19 & 118,68 & 147,738 \\
\hline 20 & 123,68 & 147,808 \\
\hline 21 & 128,68 & 147,928 \\
\hline 22 & 133,68 & 147,978 \\
\hline 23 & 138,68 & 148,038 \\
\hline 24 & 143,68 & 148,018 \\
\hline 25 & 148,68 & 147,828 \\
\hline 26 & 153,68 & 147,788 \\
\hline 27 & 158,68 & 147,738 \\
\hline 28 & 163,68 & 147,688 \\
\hline 29 & 168,68 & 147,638 \\
\hline 30 & 173,68 & 147,618 \\
\hline 31 & 178,68 & 147,788 \\
\hline 32 & 183,68 & 149,758 \\
\hline NA-MD & 187,68 & 151,638 \\
\hline РT04 & 194,48 & 152,919 \\
\hline PT05 & 197,48 & 154,084 \\
\hline PF-MD & 207,58 & 155,162 \\
\hline
\end{tabular}

ST 10 - Nossa $\mathrm{Sr}^{\mathrm{a}}$ da Guia

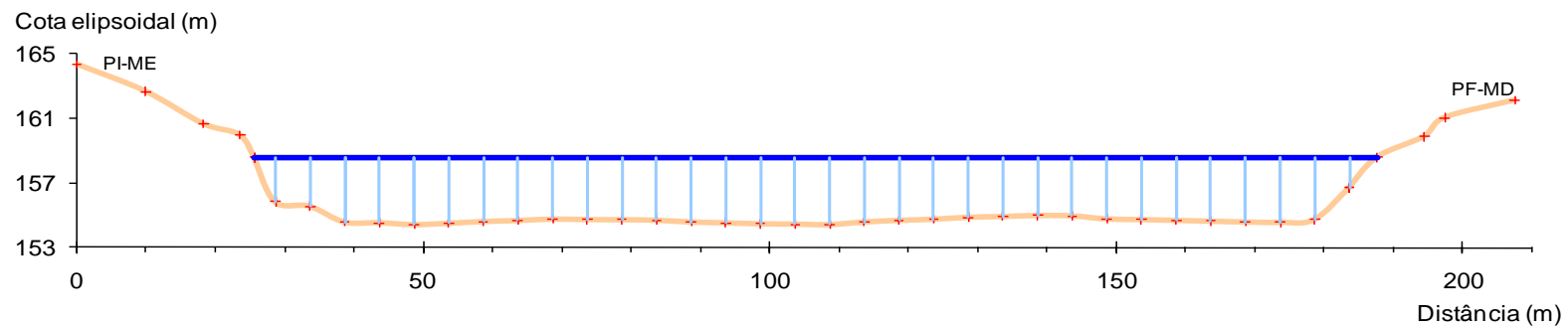


ST 11 - Porto Bandeira (Sucuri)

\begin{tabular}{|c|c|c|}
\hline Referencial & $\begin{array}{l}\text { Distância } \\
\text { transversal (m) }\end{array}$ & $\begin{array}{l}\text { Cota } \\
\text { Ortom. (m) }\end{array}$ \\
\hline $\mathrm{RN}=\mathrm{PI}$ & 0 & 154,82 \\
\hline NA-ME & 15,65 & 153,271 \\
\hline 1 & 18,65 & 151,771 \\
\hline 2 & 23,65 & 151,341 \\
\hline 3 & 28,65 & 150,121 \\
\hline 4 & 33,65 & 148,121 \\
\hline 5 & 38,65 & 148,111 \\
\hline 6 & 43,65 & 148,111 \\
\hline 7 & 48,65 & 148,271 \\
\hline 8 & 53,65 & 148,391 \\
\hline 9 & 58,65 & 148,621 \\
\hline 10 & 63,65 & 148,801 \\
\hline 11 & 68,65 & 148,871 \\
\hline 12 & 73,65 & 148,921 \\
\hline 13 & 78,65 & 148,971 \\
\hline 14 & 83,65 & 149,031 \\
\hline 15 & 88,65 & 149,101 \\
\hline 16 & 93,65 & 149,251 \\
\hline 17 & 98,65 & 149,831 \\
\hline 18 & 103,65 & 150,051 \\
\hline 19 & 108,65 & 149,231 \\
\hline 20 & 113,65 & 149,121 \\
\hline 21 & 118,65 & 149,061 \\
\hline 22 & 123,65 & 149,101 \\
\hline 23 & 128,65 & 149,151 \\
\hline 24 & 133,65 & 149,241 \\
\hline 25 & 138,65 & 149,461 \\
\hline 26 & 143,65 & 149,201 \\
\hline 27 & 148,65 & 148,971 \\
\hline 28 & 153,65 & 148,831 \\
\hline 29 & 158,65 & 148,731 \\
\hline 30 & 163,65 & 148,741 \\
\hline 31 & 168,65 & 148,751 \\
\hline 32 & 173,65 & 148,831 \\
\hline 33 & 178,65 & 149,151 \\
\hline 34 & 183,65 & 150,221 \\
\hline 35 & 188,65 & 150,691 \\
\hline 36 & 193,65 & 151,771 \\
\hline NA-MD & 195,65 & 153,271 \\
\hline РT02 & 202,15 & 155,381 \\
\hline PF-MD & 206,65 & 156,411 \\
\hline
\end{tabular}

ST 11 - Porto Bandeira (Sucuri)

Cota elipsoidal (m)

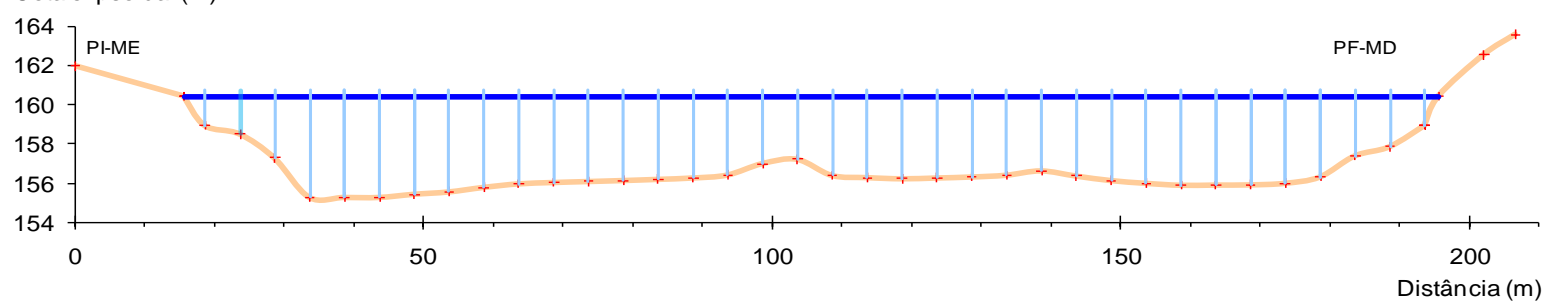


ST 12 - Passagem da Conceição

\begin{tabular}{|c|c|c|}
\hline Referencial & $\begin{array}{l}\text { Distância } \\
\text { transversal (m) }\end{array}$ & $\begin{array}{l}\text { Cota } \\
\text { Ortom. (m) }\end{array}$ \\
\hline PI-ME & 0,00 & 153,206 \\
\hline PT01 & 50,00 & 149,595 \\
\hline NA-ME & 78,80 & 147,588 \\
\hline 1 & 80,80 & 146,218 \\
\hline 2 & 85,80 & 145,218 \\
\hline 3 & 90,80 & 142,728 \\
\hline 4 & 95,80 & 142,688 \\
\hline 5 & 100,80 & 142,088 \\
\hline 6 & 105,80 & 141,488 \\
\hline 7 & 110,80 & 141,588 \\
\hline 8 & 115,80 & 140,968 \\
\hline 9 & 120,80 & 141,178 \\
\hline 10 & 125,80 & 141,558 \\
\hline 11 & 130,80 & 141,378 \\
\hline 12 & 135,80 & 141,368 \\
\hline 13 & 140,80 & 141,958 \\
\hline 14 & 145,80 & 142,278 \\
\hline 15 & 150,80 & 142,768 \\
\hline 16 & 155,80 & 142,968 \\
\hline 17 & 160,80 & 143,178 \\
\hline 18 & 165,80 & 143,458 \\
\hline 19 & 170,80 & 143,428 \\
\hline 20 & 175,80 & 143,268 \\
\hline 21 & 180,80 & 143,498 \\
\hline 22 & 185,80 & 143,378 \\
\hline 23 & 190,80 & 143,358 \\
\hline 24 & 195,80 & 142,958 \\
\hline 25 & 200,80 & 142,778 \\
\hline 26 & 205,80 & 142,458 \\
\hline 27 & 210,80 & 142,348 \\
\hline 28 & 215,80 & 142,968 \\
\hline 29 & 220,80 & 146,668 \\
\hline NA-MD & 227,80 & 147,588 \\
\hline РT02 & 267,10 & 148,775 \\
\hline PT03 & 295,70 & 151,53 \\
\hline $\mathrm{RN}=\mathrm{PF}$ & 301,50 & 154,618 \\
\hline
\end{tabular}

ST 12 - Passagem da Conceição

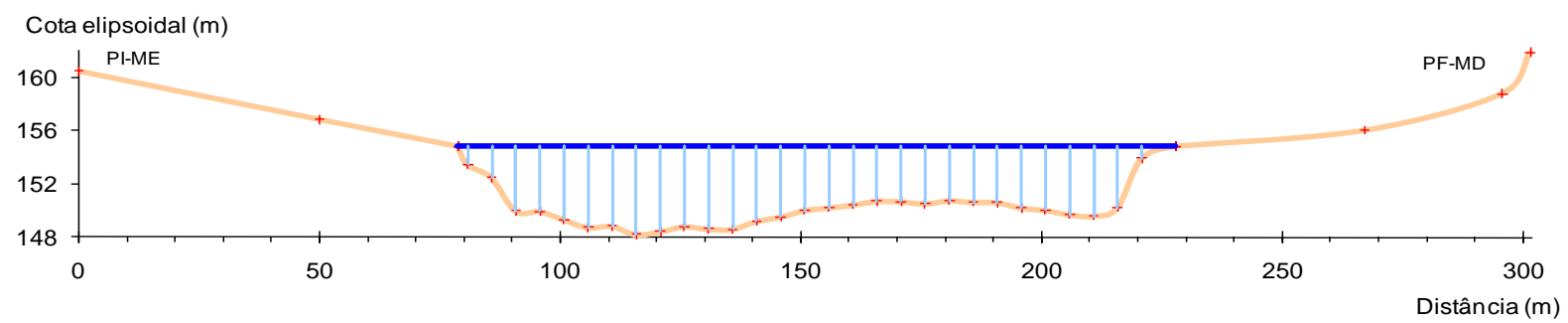


ST 13 - Cuiabá

\begin{tabular}{|c|c|c|}
\hline Referencial & $\begin{array}{l}\text { Distância } \\
\text { transversal (m) }\end{array}$ & $\begin{array}{l}\text { Cota } \\
\text { Ortom. (m) }\end{array}$ \\
\hline PI-ME & 0 & 153,392 \\
\hline PT01 & 12,55 & 150,712 \\
\hline RN01 & 25,24 & 148,762 \\
\hline РT02 & 30,85 & 148,332 \\
\hline PT03 & 34,95 & 147,332 \\
\hline PT04 & 40,55 & 144,382 \\
\hline NA-ME & 41,97 & 143,502 \\
\hline 2 & 43,97 & 142,032 \\
\hline 3 & 46,97 & 141,252 \\
\hline 4 & 51,97 & 140,702 \\
\hline 5 & 56,97 & 140,052 \\
\hline 6 & 61,97 & 139,502 \\
\hline 7 & 66,97 & 139,292 \\
\hline 8 & 71,97 & 139,322 \\
\hline 9 & 76,97 & 139,452 \\
\hline 10 & 81,97 & 139,522 \\
\hline 11 & 86,97 & 139,502 \\
\hline 12 & 91,97 & 139,462 \\
\hline 13 & 96,97 & 139,672 \\
\hline 14 & 101,97 & 139,752 \\
\hline 15 & 106,97 & 139,502 \\
\hline 16 & 111,97 & 139,542 \\
\hline 17 & 116,97 & 140,372 \\
\hline 18 & 121,97 & 140,322 \\
\hline 19 & 126,97 & 140,172 \\
\hline 20 & 131,97 & 140,292 \\
\hline 21 & 136,97 & 140,302 \\
\hline 22 & 141,97 & 140,352 \\
\hline 23 & 146,97 & 140,342 \\
\hline 24 & 151,97 & 140,322 \\
\hline 25 & 156,97 & 140,322 \\
\hline 26 & 161,97 & 140,302 \\
\hline 27 & 166,97 & 140,342 \\
\hline 28 & 171,97 & 140,382 \\
\hline 29 & 176,97 & 140,502 \\
\hline 30 & 180,97 & 140,702 \\
\hline 31 & 183,62 & 141,252 \\
\hline NA-MD & 185,62 & 143,502 \\
\hline PT05 & 189,94 & 145,892 \\
\hline PT06 & 192,47 & 148,052 \\
\hline РT07 & 201,94 & 151,672 \\
\hline PF-MD & 207,72 & 153,332 \\
\hline
\end{tabular}

\section{ST 13 - Cuiabá}

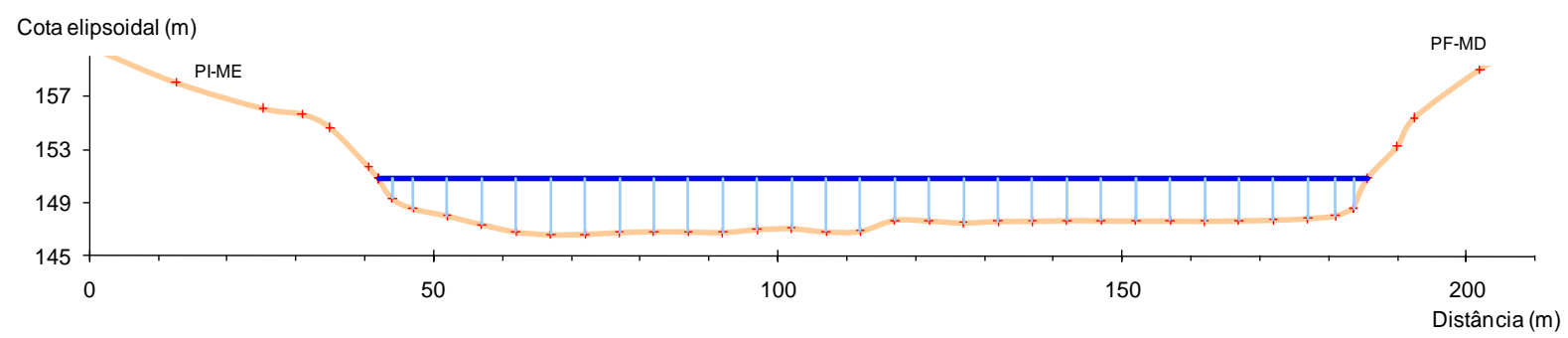


ST 14 - Bom Sucesso

\begin{tabular}{|c|c|c|}
\hline Referencial & $\begin{array}{l}\text { Distância } \\
\text { transversal (m) }\end{array}$ & $\begin{array}{l}\text { Cota } \\
\text { Ortom. (m) }\end{array}$ \\
\hline PI-ME & 0,00 & 147,637 \\
\hline РT01 & 7,00 & 147,525 \\
\hline РT02 & 11,00 & 144,772 \\
\hline NA-ME & 17,50 & 142,575 \\
\hline 1 & 20,50 & 142,015 \\
\hline 2 & 23,50 & 140,855 \\
\hline 3 & 28,50 & 140,455 \\
\hline 4 & 33,50 & 137,655 \\
\hline 5 & 38,50 & 137,805 \\
\hline 6 & 43,50 & 137,945 \\
\hline 7 & 48,50 & 137,995 \\
\hline 8 & 53,50 & 138,595 \\
\hline 9 & 58,50 & 139,055 \\
\hline 10 & 63,50 & 139,485 \\
\hline 11 & 68,50 & 139,505 \\
\hline 12 & 73,50 & 139,295 \\
\hline 13 & 78,50 & 139,605 \\
\hline 14 & 83,50 & 139,435 \\
\hline 15 & 88,50 & 139,015 \\
\hline 16 & 93,50 & 138,735 \\
\hline 17 & 98,50 & 138,395 \\
\hline 18 & 103,50 & 138,305 \\
\hline 19 & 108,50 & 137,995 \\
\hline 20 & 113,50 & 138,115 \\
\hline 21 & 118,50 & 138,125 \\
\hline 22 & 123,50 & 138,275 \\
\hline 23 & 128,50 & 138,295 \\
\hline 24 & 133,50 & 138,375 \\
\hline 25 & 138,50 & 138,505 \\
\hline 26 & 143,50 & 138,595 \\
\hline 27 & 148,50 & 138,735 \\
\hline 28 & 153,50 & 138,815 \\
\hline 29 & 158,50 & 138,895 \\
\hline 30 & 163,50 & 139,105 \\
\hline 31 & 168,50 & 139,145 \\
\hline 32 & 173,50 & 139,235 \\
\hline 33 & 178,50 & 139,275 \\
\hline 34 & 183,50 & 139,485 \\
\hline 35 & 188,50 & 139,855 \\
\hline 36 & 193,50 & 140,675 \\
\hline 37 & 198,50 & 140,975 \\
\hline 38 & 203,50 & 141,975 \\
\hline NA-MD & 208,50 & 142,575 \\
\hline PT03 & 225,10 & 146,29 \\
\hline PT04 & 227,10 & 146,422 \\
\hline $\mathrm{RN}=\mathrm{PF}$ & 254,60 & 149,408 \\
\hline
\end{tabular}

ST 14 - Bom Sucesso

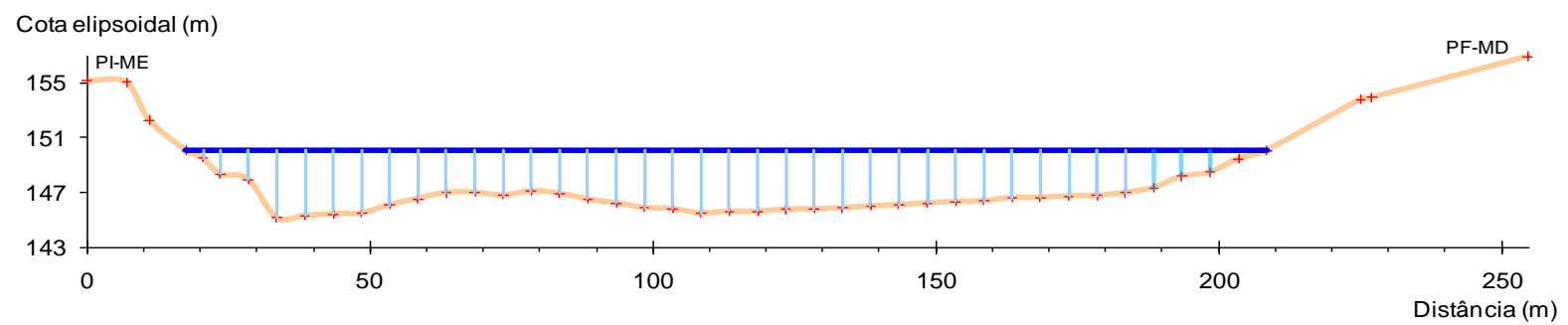


ST 15 - Praia Grande

\begin{tabular}{|lll|}
\hline Referencial & $\begin{array}{l}\text { Distância } \\
\text { transversal (m) }\end{array}$ & $\begin{array}{l}\text { Cota } \\
\text { Ortom. }(\mathrm{m})\end{array}$ \\
PI-ME & 0,00 & 144,277 \\
NA-ME & 8,80 & 141,442 \\
1 & 11,80 & 140,412 \\
2 & 14,80 & 139,642 \\
3 & 19,80 & 138,852 \\
4 & 24,80 & 139,012 \\
5 & 29,80 & 138,992 \\
6 & 34,80 & 138,632 \\
7 & 39,80 & 138,572 \\
8 & 44,80 & 137,882 \\
9 & 49,80 & 137,652 \\
10 & 54,80 & 138,062 \\
11 & 59,80 & 136,642 \\
12 & 64,80 & 136,572 \\
13 & 69,80 & 136,562 \\
14 & 74,80 & 136,252 \\
15 & 79,80 & 136,192 \\
16 & 84,80 & 135,742 \\
17 & 89,80 & 137,062 \\
18 & 94,80 & 136,982 \\
19 & 99,80 & 137,342 \\
20 & 104,80 & 137,632 \\
21 & 109,80 & 138,922 \\
22 & 114,80 & 138,892 \\
23 & 119,80 & 139,412 \\
24 & 124,80 & 139,512 \\
25 & 129,80 & 139,342 \\
26 & 134,80 & 139,532 \\
27 & 139,80 & 139,722 \\
28 & 144,80 & 140,632 \\
NA-MD & 148,80 & 141,442 \\
PT01 & 159,80 & 144,535 \\
PT02 & 172,80 & 146,08 \\
PT03 & 201,80 & 146,623 \\
RN=PF & 209,30 & 148,552 \\
\hline
\end{tabular}

ST 15 - Praia Grande

Cota elipsoidal $(\mathrm{m})$

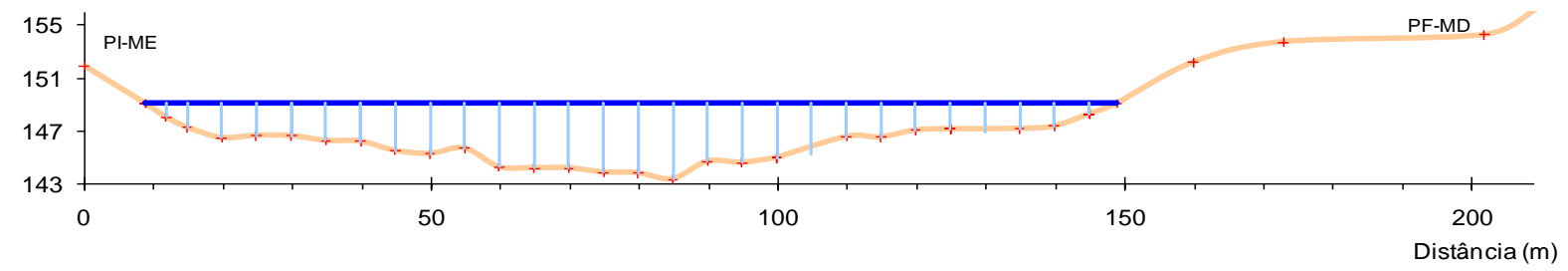


ST 16 - Santo Antônio do Leverger

\begin{tabular}{|c|c|c|}
\hline Referencial & $\begin{array}{l}\text { Distância } \\
\text { transversal (m) }\end{array}$ & $\begin{array}{l}\text { Cota } \\
\text { Ortom. (m) }\end{array}$ \\
\hline $\mathrm{RN}=\mathrm{PI}$ & 0,00 & 144,518 \\
\hline PT01 & 0,30 & 143,352 \\
\hline РT02 & 2,00 & 142,986 \\
\hline NA-ME & 13,40 & 141,02 \\
\hline 1 & 15,40 & 138,71 \\
\hline 2 & 20,40 & 138,56 \\
\hline 3 & 25,40 & 137,22 \\
\hline 4 & 30,40 & 137,2 \\
\hline 5 & 35,40 & 136,99 \\
\hline 6 & 40,40 & 136,86 \\
\hline 7 & 45,40 & 136,79 \\
\hline 8 & 50,40 & 136,7 \\
\hline 9 & 55,40 & 136,56 \\
\hline 10 & 60,40 & 137 \\
\hline 11 & 65,40 & 137,1 \\
\hline 12 & 70,40 & 136,96 \\
\hline 13 & 75,40 & 136,81 \\
\hline 14 & 80,40 & 136,9 \\
\hline 15 & 85,40 & 137,06 \\
\hline 16 & 90,40 & 136,99 \\
\hline 17 & 95,40 & 136,99 \\
\hline 18 & 100,40 & 136,92 \\
\hline 19 & 110,40 & 136,9 \\
\hline 20 & 120,40 & 136,96 \\
\hline 21 & 130,40 & 136,39 \\
\hline 22 & 140,40 & 137,1 \\
\hline 23 & 150,40 & 136,59 \\
\hline 24 & 160,40 & 137,25 \\
\hline 25 & 170,40 & 136,99 \\
\hline 26 & 180,40 & 136,32 \\
\hline 27 & 190,40 & 136,22 \\
\hline 28 & 200,40 & 136,55 \\
\hline 29 & 210,40 & 136,41 \\
\hline 30 & 215,40 & 136,51 \\
\hline 31 & 220,40 & 136,7 \\
\hline 32 & 225,40 & 136,58 \\
\hline 33 & 230,40 & 136,46 \\
\hline 34 & 235,40 & 136,9 \\
\hline 35 & 240,40 & 137,27 \\
\hline 36 & 245,40 & 137,71 \\
\hline 37 & 250,40 & 140,22 \\
\hline NA-MD & 255,40 & 141,02 \\
\hline PF-MD & 278,20 & 143,645 \\
\hline
\end{tabular}

ST 16 - Santo Antônio do Leverger

Cota elipsoidal (m)

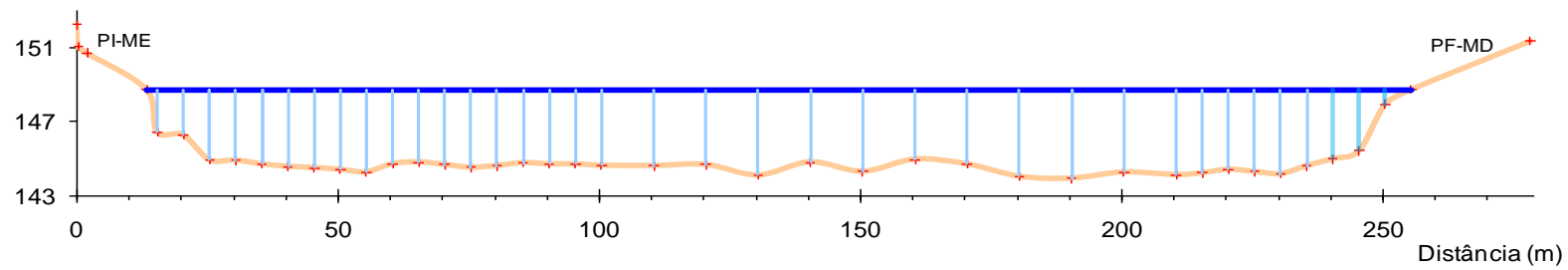

